
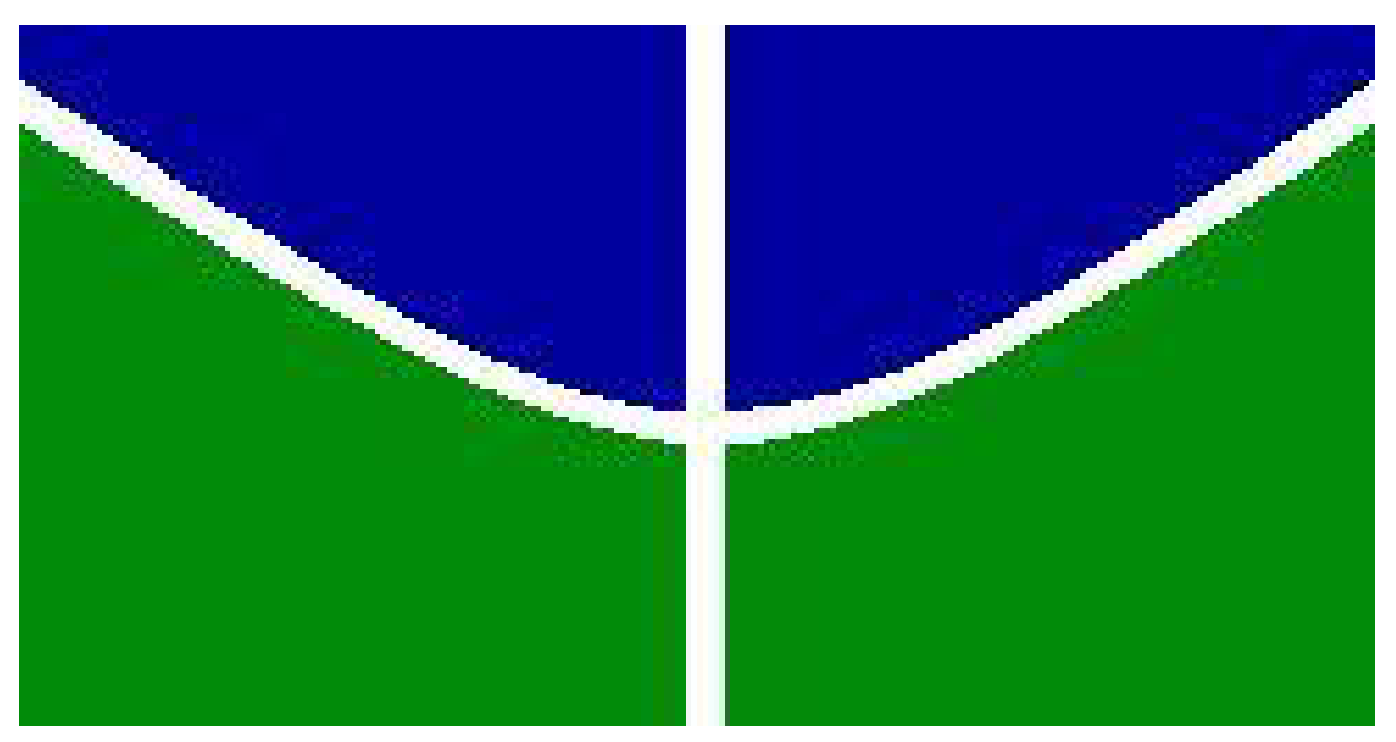

\title{
USO TRADICIONAL, MANEJO E PROCESSAMENTO DA PIAÇAVA DA BAHIA (Attalea funifera Mart.)
}

NOARA MODESTO PIMENTEL

TESE DE DOUTORADO EM CIÊNCIAS FLORESTAIS DEPARTAMENTO DE ENGENHARIA FLORESTAL

FACULDADE DE TECNOLOGIA UNIVERSIDADE DE BRASÍLIA 


\author{
UNIVERSIDADE DE BRASÍLIA \\ FACULDADE DE TECNOLOGIA \\ DEPARTAMENTO DE ENGENHARIA FLORESTAL
}

\author{
USO TRADICIONAL, MANEJO E \\ PROCESSAMENTO DA PIAÇAVA \\ DA BAHIA (Attalea funifera Mart.)
}

NOARA MODESTO PIMENTEL

ORIENTADOR: CLÁUDIO HENRIQUE SOARES DEL MENEZZI

CO-ORIENTADORA: ALBA VALÉRIA REZENDE

TESE DE DOUTORADO EM CIÊNCIAS FLORESTAIS

PUBLICAÇÃO: PPGEFL.TD - 055/2015

BRASÍLIA - DF, MAIO/2015 
UNIVERSIDADE DE BRASÍLIA

FACU LDADE DE TECNOLOGIA

DEPARTAMENTO DE ENGENHARIA FLORESTAL

PROGRAMA DE PÓS-GRADUAÇÃO EM CIÊNCIAS FLORESTAIS

USO TRADICIONAL, MANEJO E

PROCESSAMENTO DA PIAÇAVA DA BAHIA (Attalea funifera Mart.)

NOARA MODESTO PIMENTEL

TESE DE DOUTORADO SUBMETIDA AO PROGRAMA DE PÓS GRADUAÇÃO EM CIÊNCIAS FLORESTAIS, DO DEPARTAMENTO DE ENGENHARIA FLORESTAL, DA FACULDADE DE TECNOLOGIA DA UNIVERSIDADE DE BRASÍLIA, COMO PARTE DOS REQUISITOS NECESSÁRIOS PARA OBTENÇÃO DO GRAU DE DOUTOR.

\section{APROVADA POR:}

Prof. Dr. Cláudio Henrique Soares Del Menezzi (Departamento de Engenharia Florestal, UnB); (Orientador)

Prof. Dr. Reginaldo Sergio Pereira (Departamento de Engenharia Florestal, UnB);

(Examinador interno)

Prof. Dr. Ildeu Soares Martins (Departamento de Engenharia Florestal, UnB);

(Examinador interno)

Profa. Dr. Edson Jose Vidal da Silva (ESALQ/Universidade de São Paulo - USP/Piracicaba); (Examinador externo)

Profa. Dra. Silvia Maria Ferreira Guimarães (FCE / UnB)

(Examinadora externa)

Prof. Dr. Álvaro Nogueira de Souza (Departamento de Engenharia Florestal, UnB)

(Suplente)

Brasília, 15 de maio de 2015. 


\section{FICHA CATALOGRÁFICA}

\section{PIMENTEL, NOARA MODESTO}

Uso Tradicional, Manejo e Processamento da Piaçava da Bahia (Attalea funifera Mart.) /Noara Pimentel. - Brasília, 2015. 210 f. : il. ; 19,7 cm.

Tese (Doutorado) - Universidade de Brasília, Faculdade de Tecnologia, Departamento de Engenharia Florestal. Orientador: Cláudio Del Menezzi. Co-orientadora: Alba Rezende.

1. Extrativismo tradicional da piaçava

2. Attalea funifera

3. Produto florestal não madeireiro

4. Processamento da fibra vegetal

I. EFL/FT/UnB

II. Título (série)

\section{CDD}

\section{REFERÊNCIA BIBLIOGRÁFICA}

PIMENTEL, N. M. (2015). Uso Tradicional, Manejo e Processamento da Piaçava (Attalea funifera Mart.) da Bahia. Tese de Doutorado em Ciência Florestal, Publicação PPGEFL. TD - 055/2015, Departamento de Engenharia Florestal, Universidade de Brasília, DF, 210p.

\section{CESSÃO DE DIREITOS}

AUTORA: Noara Modesto Pimentel

TÍTULO: Uso Tradicional, Manejo e Processamento da Piaçava (Attalea Funifera Mart.) da Bahia GRAU: Doutor ANO: 2015

É concedida a Universidade de Brasília permissão para reproduzir cópias desta tese de doutorado e para emprestar ou vender tais cópias somente para propósitos acadêmicos e científicos. A autora reserva outros direitos de publicação e nenhuma parte dessa tese de doutorado pode ser reproduzida sem autorização por escrito da autora.

Noara Modesto Pimentel

Caixa Postal 3803 CEP: 70.089-970

Brasília - DF 
Dedico aos meus pais, Ana Maria Modesto e Allan Kardec Pimentel Ao Leonardo Santana pelo constante incentivo e apoio Ás minhas duas neguinhas: Ana Terra e Iandara Pimentel Santana. Á todos os meus parentes e irmãos de caminhada... 


\section{AGRADECIMENTOS}

Agradecimentos especiais ao meu orientador Dr. Claudio Del Menezzi por me lembrar que eu devia seguir, mesmo sem conhecer o caminho; à co-orientadora Alba Valéria Rezende por aceitar o desafio dos PFNMs; ao Program de Pós Graduação em Ciências Florestais da UnB; à CAPES (Coordenação de Aperfeiçoamento de Pessoal de Nivel Superior) pela bolsa de doutorado; ao Dr. Herbert Lima do Laboratório de Oleaginosas da Embrapa Cerrados (Planaltina-DF) pela extração do óleo vegetal da piaçava; ao Sr. Luiz Ferraro da Secretaria do Meio Ambiente da Bahia (SEMA) por disponibilizar base de dados do mapeamento da Bahia; ao Prof. Luiz Alberto Mattos Silva da UESC pelo apoio na coleta da amostra da piaçava e depósito nos herbários da UESC e da UnB; ao Prof. Floriano Pastore pela disposição de fazer as análises do óleo vegetal e polpa da piaçava; aos Engenheiros Florestais Leonardo Santana (UFPE), Bruno Freitas (UFS) e Andréia Damasceno (UNESP/Botucatu) pelo apoio nos trabalhos de campo; ao Haroldo Oliveira consultor do MDA; aos técnicos Gileno Araújo e Pedro Matos por compartilhar saberes com paciência e comprometimento com os extrativistas da piaçava. Aos extrativistas quilombolas: Sr. Amâncio dos Santos por valorizar as pessoas que lidam com a piaçava; Sr. Domingos Leonardo dos Santos (Lió) pela sabedoria de empreender, Sra. Renilda pela amizade, Sr. Carlos pelo esforço de campo, Sra. Mara pelo cardápio ofertado, Dona Ana pelas mãos calejadas de catar a piaçava, Dona Damiana pelas trocas, Dona Cotinha pelo acolhimento, Sr. Manoel Angelo pela disposição em colaborar, Sr. Aloisio de Jesus pelo cuidado com a mata, Sr. André Assunção por ensinar, Dona Joanita Assunção pelo delicioso mingau de 'satim', Sr. Hamilton assunção pela entrega, Sra. Jose Assunção pelas coletas do fruto, Sr. Alan Ribeiro Assunção pela cata e corte da piaçava; aos tiradores Sr. Ivanildo Santos de Jesus, Sr. Arnoldo, Sr. Passarão, Sr. Adjailton Nascimento do Rosário (Jaba); ao coletor de frutos Sr. Lucindo Santana (Dinho); às extrativistas da palha Dona Joana Dias Pereira (Jarinha), Sra. Cleonice Santos e Sra. Genilza. Aos artesões José Roque; Creuza Amorim ; e Geisa Santos pelo empenho em repassar os seus saberes aos demais extrativistas artesões da piaçava da Bahia. 


\author{
“(...) Agora que eu quero ver \\ se couro de gente é pra queimar \\ Agora que eu quero ver \\ se couro de gente é pra queimar \\ Vou pedir pra São João \\ Cosme e Damião \\ Pra nos ajudar (...)”. \\ Música de José Dias Sobrinho
}

"Muitos pensam que a pesquisa científica é uma atividade puramente racional, na qual o objetivismo lógico é o único mecanismo capaz de gerar conhecimento. Como resultado, os cientistas são vistos como insensíveis e limitados, um grupo de pessoas que corrompe a beleza da Natureza ao analisá-la matematicamente [...] A ciência vai muito além da sua mera prática. Por trás das fórmulas complicadas, das tabelas de dados experimentais e da linguagem técnica, encontra-se uma pessoa tentando transcender as barreiras imediatas da vida diária, guiada por um insaciável desejo de adquirir um nível mais profundo de conhecimento e de realização própria. Sob esse prisma, o processo criativo científico não é assim tão diferente do processo criativo nas artes, isto é, um veículo de autodescoberta que se manifesta ao tentarmos capturar a nossa essência e lugar no Universo" (GLEISER, 1997). 


\section{RESUMO}

\section{USO TRADICIONAL, MANEJO E PROCESSAMENTO DA PIAÇAVA (Attalea funifera MART.) DA BAHIA}

A palmeira de piaçava (Attalea funifera Mart.) é endêmica do Bioma Mata Atlântica, ocorre no litoral da Bahia, Brasil, seus PFNMs são utilizados antes da chegada dos portugueses na costa brasileira, por comunidades indígenas. Esse conhecimento tradicional rapidamente foi repassado aos colonizadores e aos negros Africanos. Atualmente a espécie já é cultivada em grandes plantações e o extrativismo mantido pelas populações negras residentes na região, agricultores familiares e comunidades quilombolas que ainda conservam esse recurso em seus fragmentos de florestas e em pequenos plantios, localmente denominados de 'mata de piaçava'. As fibras vegetais são comercializadas na forma bruta, pré-beneficiada, beneficiadas, vassouras e artesanatos com a fibra vegetal beneficiada. Este trabalho abordou técnicas e tecnologias que envolveram o manejo e o processamento da fibra vegetal, através de levantamentos de campo, troca de saberes entre pesquisadores e extrativistas da piaçava, implantação de parcelas em áreas de plantio, experimentos de campo com a fibra vegetal e informações preliminares com vistas ao aproveitamento da polpa do fruto e o óleo vegetal da semente. Encontrou-se 888 palmeiras por hectare na área do produtor, aproximadamente $65 \%$ dessas estavam produzindo fibras vegetais. Os plantios quilombolas apresentaram aproximadamente 1.250 palmeiras por hectare, $83 \%$ dessas estavam produzindo fibras vegetais comercializáveis. A produtividade média de fibra por planta na fase de 'bananeira em produção' foi de 1,2 kg/planta/ano e na fase coqueiro uma média de 3,68 kg/planta/ano. Após mais de 12 meses da primeira extração, a média de fibra por planta na segunda extração foi de $0,71 \mathrm{~kg} / \mathrm{planta} /$ ano na fase 'bananeira em produção' e de $3,14 \mathrm{~kg} /$ planta/ano nas plantas coqueiro. A etapa de prébeneficiamento apresentou 17,3\% de resíduos, no beneficiamento apresentou uma média de $26,8 \%$ de resíduos e aproximadamente $15,3 \%$ de descarte na etapa de confecção das vassouras de piaçava. Portanto, ao longo do processo produtivo foi descartado aproximadamente $41,8 \%$ de resíduos, aproveitados $35,6 \%$ de fibras vegetais fino/média, $5,3 \%$ de fibras grosso-médias e 17\% corresponderam ao subproduto 'fita' para cobertura de quiosques de praia. Considerando a comercialização das fibras vegetais da piaçava beneficiadas (cortadas), as margens brutas de ganhos financeiros foram: 10,47\% para o 'tirador; $7,62 \%$ para catadeira; $28,57 \%$ para o cortador; e $52 \%$ para o atravessador. Apesar das dificuldades de acessar o mercado de vassouras da piaçava, os extrativistas dominam as técnicas e tecnologias envolvidas no manejo e processamento da fibra vegetal, o que permite que a renda extrativista familiar, com a fibra da piaçava, seja melhorada. A renda extrativista atual variou de $\mathrm{R} \$ 360,00$ a $\mathrm{R} \$ 600,00$ por mês. Supondo o cenário onde o extrativista domina todo o processo produtivo da confecção das vassouras de piaçava, a renda mensal bruta, de um único extrativista, trabalhando 25 dias por mês, oito horas por dia, passaria para $\mathrm{R} \$ 2.460,00$ por mês. O custo de produção para produzir essas 410 vassouras ficaria entorno de $\mathrm{R} \$ 795,38$, então o ganho líquido mensal passaria para $\mathrm{R} \$$ 1.664,63. Esses valores comprovaram que o maior domínio das etapas de produção, manejo e aproveitamento da fibra vegetal da piaçava, realizada pelos extrativistas, agrega valor ao produto final e eleva a renda dos quilombolas e pequenos agroextrativistas.

Palavras chaves: Produto Florestal Não Madeireiro; Uso sustentável da Mata Atlântica; fibra vegetal da piaçava; e frutos da piaçava. 


\section{ABSTRACT}

\section{BAHIA PIAÇAVA (Attalea funifera MART.) TRADITIONAL USE, MANAGEMENT AND PROCESSING}

Piassava palm tree (Attalea funifera Mart.) is endemic of Atlantic Forest biome and it occurs in Bahia coast, Brazil. It has been used by indigenous communities even before the Portuguese arrived on Brazilian coast. This traditional knowledge was rapidly passed on to colonizers and black communities. The species is currently cultivated in large plantations and extractive activities are maintained by black population living in the region, family farmers and quilombola communities that still retain this resource in their forest fragments and in small plantations, locally named 'piaçava forest'. Vegetable fibers are commercialized in raw form, pre-benefited, benefited, brooms and handicraft using benefited vegetable fibers. This dissertation covers techniques and technologies involving vegetable fiber management and processing, through field surveys, knowledge exchange between researchers and piaçava extractors, implementation of parcels in planting areas, vegetable fiber yield tests and preliminary information in order to take advantage of fruit pulp and seed vegetable oil. It was found 888 palm trees per hectare in producer area, approximately $65 \%$ of them are producing vegetable fibers. Quilombola plantations presented approximately 1.250 palm trees per hectare, $83 \%$ of them are producing marketable vegetable fibers. Average fiber productivity per plant during "banana tree in production" phase was $1.2 \mathrm{~kg} / \mathrm{plant} /$ year and during coconut tree phase was about average of $3.68 \mathrm{~kg} / \mathrm{plant} /$ year. After more than 12 months of first extraction the average fiber per plant in second extraction was $0.71 \mathrm{~kg} /$ plant $/$ year in "banana tree in production" phase and $3.14 \mathrm{~kg} /$ plant/year in coconut trees. Pre-beneficiation phase presented $17.3 \%$ of waste, beneficiation presented an average of $26.8 \%$ of waste and approximately $15,3 \%$ of disposal of fine/media fiber during piassava brooms confection phase. Therefore throughout productive process approximately $41.8 \%$ of waste is discarded, $35.6 \%$ of fine/media vegetable fibers are used in broom confection and $17 \%$ corresponds to by-product "stripe" to cover beach kiosks and 5,3\% of thick/media fiber. Considering the commercialization of piaçava benefited vegetable fibers (cut) gross margins were: $10.47 \%$ to the extractor; $7,62 \%$ to the harvester; $28.57 \%$ to the "quilombolas"; and $52 \%$ to the intermediary. Despite the difficulties of accessing the piaçava broom market, the extractors dominate the techniques and technologies involved in the management and processing of vegetable fiber, which allows that the extractive family incoming be improved with palm fiber. Current extractive income varies from $\mathrm{R} \$ 360.00$ to $\mathrm{R} \$ 600.00$ per month, supposing the scenario where the extractor dominate the whole productive process of piaçava broom confection, gross monthly income of a single extractor, working 25 days a month, eight hours a day, would be $\mathrm{R} \$ 2,460.00$ per month. Production costs to produce 410 brooms would be approximately $\mathrm{R} \$ 795.38$, then net monthly gain would be $\mathrm{R} \$ 1.664 .63$. Those amounts prove that dominating piassava vegetable fiber production, management and exploitation by extractors adds value to final product and raises quilombolas and small extractors' income.

Key words: Non-wood Forest Product; Sustainable usage of Atlantic Forest; piassava vegetable fiber; and piassava fruit. 


\section{SUMÁRIO}

INTRODUÇÃO GERAL ................................................................................................. 1

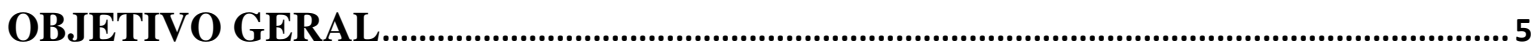

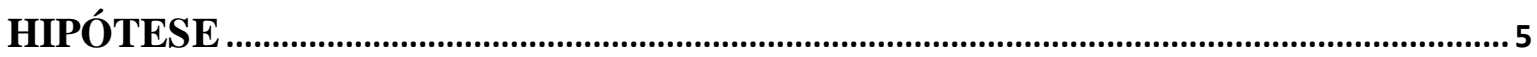

CAPÍTULO 1 - MANEJO DA FIBRA DE PIAÇAVA (ATTALEA FUNIFERA MART.) NO QUILOMBO BREJO GRANDE ITUBERÀ E PRODUTOR DE CANAVIEIRAS - BAHIA

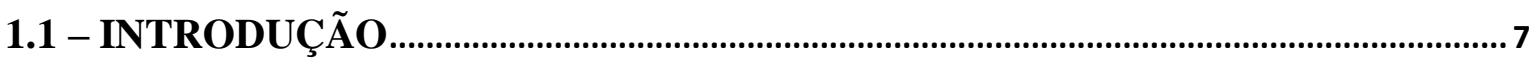

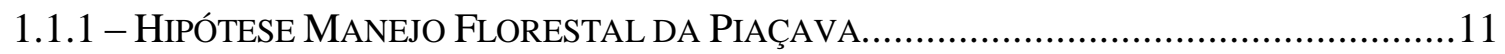

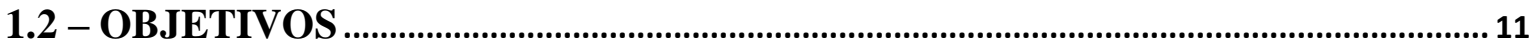

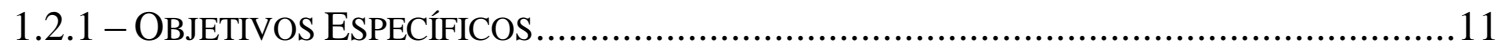

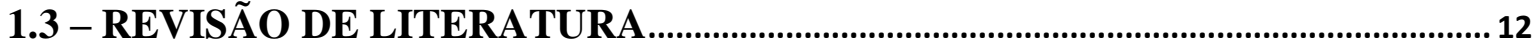

1.3.1 - OCUPAÇÃO MATA ATLÂNTICA E O EXTRATIVISMO DE PFNMS............................12

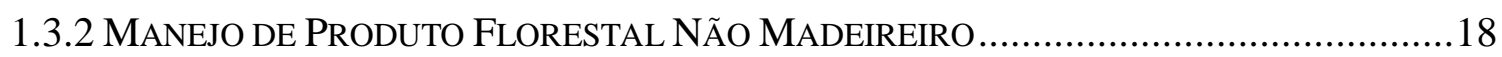

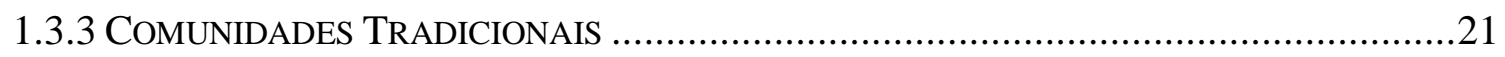

1.3.4 - PIAÇAVA (ATTALEA FUNIFERA MARTIUS) DA BAHIA ............................................2

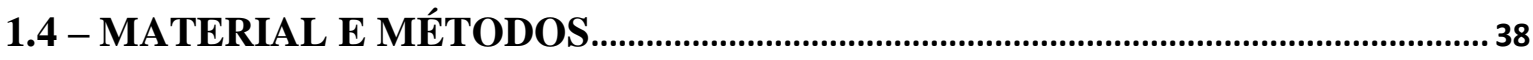

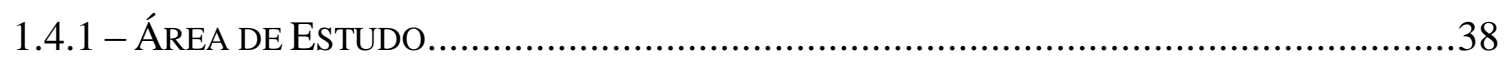

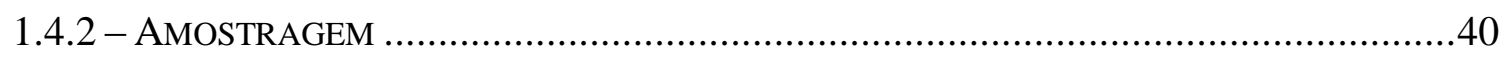

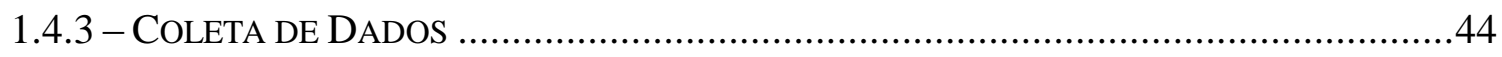

1.4.4 - ANÁLISE DOS DADOS ......................................................................................46

1.4.4.1 - Análise da precisão da amostragem .......................................................46

1.4.4.2 - Análise estatística descritiva das variáveis relacionadas à produção da

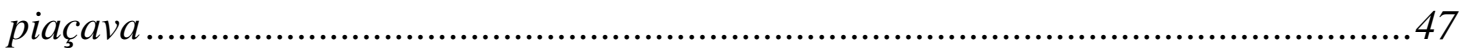

1.4.4.3 - Modelagem da produção de fibras de piaçava ............................................48

2.4.4.4 - Eficiência do manejo extrativista da fibra vegetal na área quilombola e na área particular...................................................................................................49

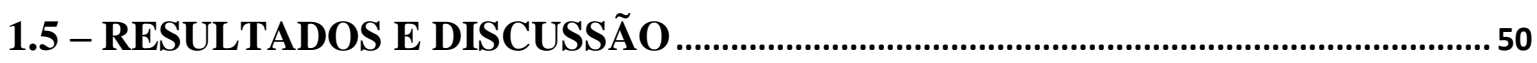

1.5.1 - TERMOS TRADICIONAIS DO EXTRATIVISMO DA PIAÇAVA DA BAHIA .....................52

1.5.2 - TÉCNICAS E TECNOLOGIAS DE EXTRAÇÃO DA FIBRA VEGETAL..............................58

1.5.2.1 - Extração Indígena da Fibra Bruta de Piaçava .............................................60

1.5.2.1 - Extração quilombola da fibra bruta de piaçava ...........................................61

1.5.2.3 - Extração da fibra bruta pelo produtor local .............................................65

1.5.3 - PRECISÃO DA AMOSTRAGEM REALIZADA NAS DUAS ÁREAS COM PLANTAÇÃO DE

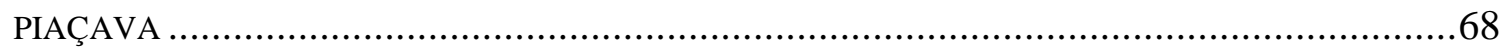

1.5.4 - DESCRIÇÃO ESTATÍSTICA DAS VARIÁVEIS RELACIONADAS À PRODUÇÃO DA

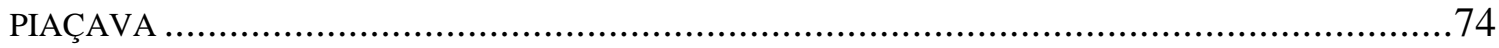

1.5.5 - MODELAGEM DA PRODUÇÃO DE FIBRAS DE PIAÇAVA POR PALMEIRA (BP E COQ). 77 1.5.6 - ESTOQUE PRODUTIVO DAS ÁREAS AMOSTRADAS ............................................. 81 
1.5.6.1 - Potencial produtivo da piaçava no quilombo ..............................................82

1.5.6.2 - Potencial produtivo da piaçava do produtor local .....................................85

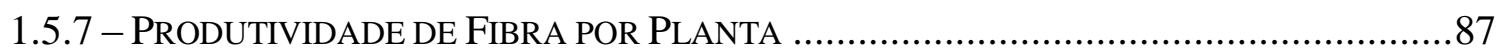

1.5.7.1 Produtividade de Fibra por Planta do Quilombo..........................................89

1.5.7.2 - Produtividade de Fibra por Planta da Propriedade .................................... 91

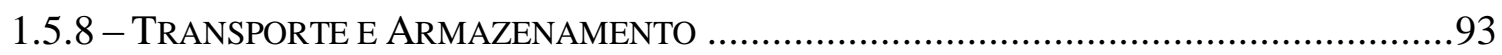

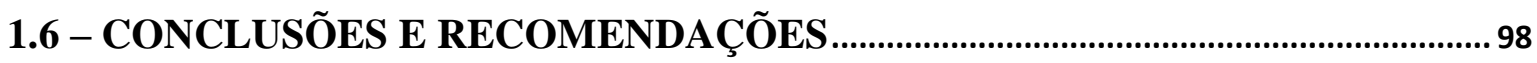

CAPÍTULO 2 - PROCESSAMENTO DA FIBRA VEGETAL E FRUTO DA

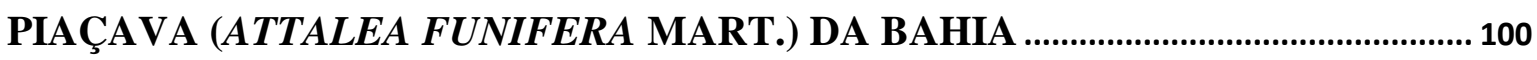

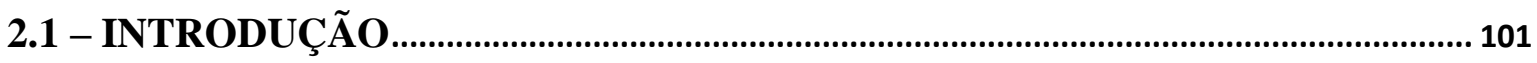

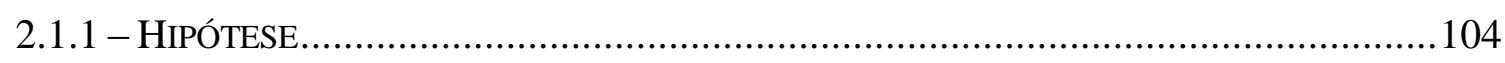

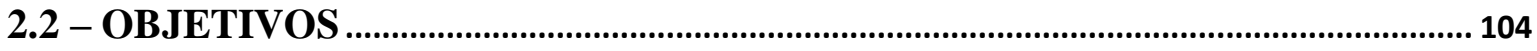

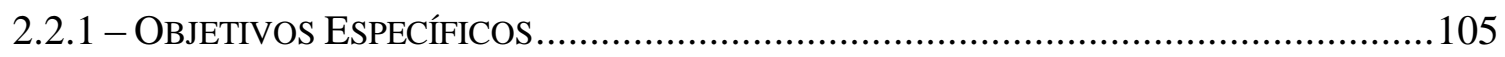

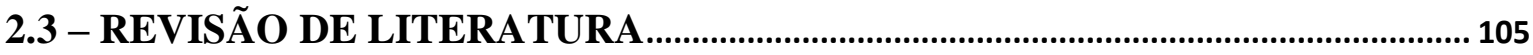

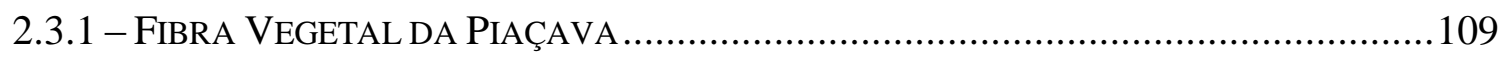

2.3.2 - CAdEIA Produtiva dA FibRA Vegetal da PiAÇAVA ....................................... 115

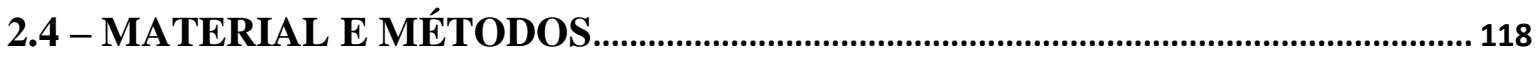

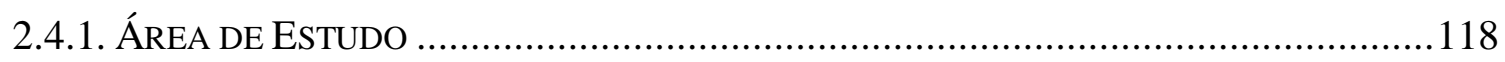

2.4.2 - Metodologia do Processo Produtivo da Fibra Vegetal da PiaçaVA ...... 119

2.4.2.1 - Empreendimentos Avaliados.................................................................. 120

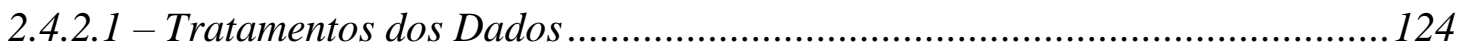

2.4.3 - Metodologia da CAdeIA Produtiva.......................................................... 126

2.4.4 - METOdologia de APRoveitamento do Fruto E DA PolPA DE 'SATIM' .......... 127

2.4.5 - Metodologia de APRoveitamento do Óleo Vegetal ...................................131

2.4.5.1 - Secagem e Determinação do Teor de Umidade Percentual ......................... 133

2.4.5.2 - Extração do Óleo Vegetal e Determinação do Rendimento em Óleo Fixo.133

2.4.6 - EXTRAÇÃO DA FOLHA DA PIAÇAVA Mirim DO NORTE DA BAHIA ....................... 134

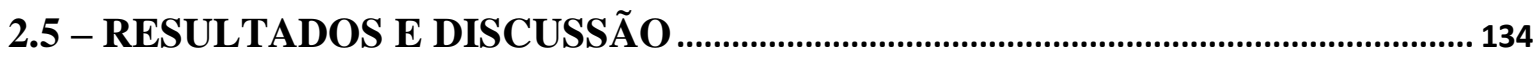

2.5.1 - FIBRA VEGETAL DA PIAÇAVA DA BAHIA ....................................................... 140

2.5.1.1 - Pré-beneficiamento da Fibra Vegetal ..................................................... 143

2.5.1.2 - Beneficiamento de Fibra Vegetal.......................................................... 147

2.5.1.3 - Confecção das Vassouras de Piaçava ..................................................... 151

2.5.1.4 - Rendimento Total do Processo Produtivo da Fibra Vegetal ....................... 155

2.5.2 - CAdEIA EXTRATIVISTA DA FibRA VEGETAl DA PiAÇAVA.....................................159

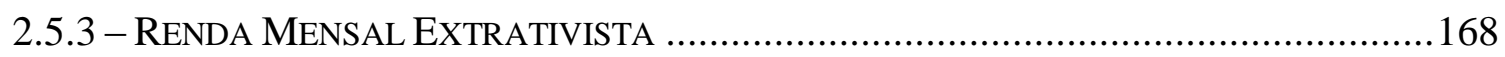

2.5.4 - CENÁRIO do APROVEITAMENTO DA FIBRA VEGETAL ........................................ 171

2.5.5 - APROVEITAMENTO DO FRUTO DA PIAÇAVA DA BAHIA........................................ 173

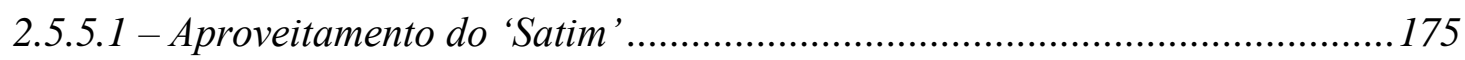

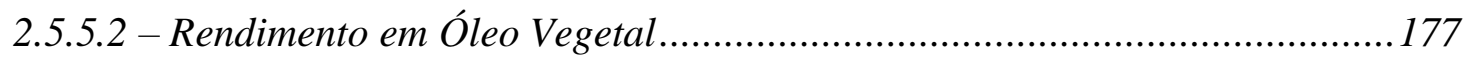

2.5.6 - APROVEITAMENTO DA FOLHA DA PIAÇAVA DA BAHIA...................................... 179 
2.6 - CONCLUSÕES E RECOMENDAÇÕES

185

REFERENCIAS BIBLIOGRÁFICAS.............................................................................187

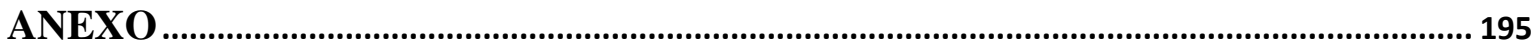

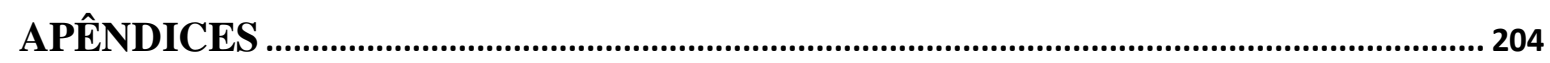




\section{LISTA DE TABELAS}

Tabela 01: Comunidades quilombolas certificadas pela fundação palmares no baixo sul baiano.

Tabela 02 - Detalhamento das fases de desenvolvimento e produção da palmeira de piaçava nas regiões de santa cruz de cabrália, porto seguro e ituberá.

Tabela 03: Produção de fibra por planta $(\mathrm{kg})$ 37

Tabela 04: Área (ha) dos plantios de piaçava do quilombo brejo grande

Tabela 05: Identificação do plantio e tamanho da área (ha) e idade dos plantios de piaçava selecionados no quilombo brejo grande.

Tabela 06: Sistemas de manejo e amostragem adotados

Tabela 07: Fases de desenvolvimento da palmeira de piaçava adotada neste estudo:

Tabela 08: Tempo médio (minutos) de subida e extração da fibra bruta das 42 plantas mensuradas nas 11 parcelas amostradas neste estudo.

Tabela 09: Número e comprimento de 'capas' por planta e por fase de desenvolvimento da piaçava.

Tabela 10: Tempo médio (minutos) de subida e extração da fibra bruta das plantas mensuradas nas 06 parcelas amostradas no quilombo de brejo grande.

Tabela 11: Número de 'capas' e número de folhas por planta e por fase produtiva de desenvolvimento da piaçava no quilombo brejo grande de ituberá.

Tabela 12: Comprimento de 'capas' por planta e por fase produtiva de desenvolvimento da piaçava no quilombo brejo grande de ituberá.

Tabela 13: Tempo médio (minutos) de subida e extração da fibra bruta das plantas mensuradas nas 05 parcelas amostradas na propriedade particular em canavieiras.

Tabela 14: Número de 'capas' e número de folhas por planta e por fase produtiva de desenvolvimento nas 05 parcelas implantadas na propriedade particular em canavieiras... 67

Tabela 15: Comprimento de 'capas' por planta e por fase produtiva de desenvolvimento da piaçava na propriedade particular em canavieiras.

Tabela 16: Tempo médio de extração por parcelas e fase de desenvolvimento

Tabela 17: Resultado do inventário que avaliou a densidade de piaçavas ( $\mathrm{n} / \mathrm{ha}$ ) em duas plantações (área particular e quilombola), localizadas no estado da bahia.

Tabela 18: Resultado do inventário que avaliou o número de folhas abertas verdes e secas (plantas saudáveis) em palmeiras produtivas (BP e COQ) de piaçavas ( $\left.\mathrm{n}^{\mathrm{o}} / \mathrm{ha}\right)$ em duas plantações (área particular e quilombola), localizadas no estado da bahia.

Tabela 19: Estatística descritiva de palmeiras produtivas (BP) de piaçava amostradas na área particular, localizada no município de canavieiras, bahia.

Tabela 20: Estatística descritiva de palmeiras produtivas (BP) de piaçava amostradas no quilombo brejo grande, localizado no município de ituberá, bahia.

Tabela 21: Estatística descritiva de coqueiros (COQ) de piaçava amostrados na área particular, localizada no município de canavieiras, bahia. 
Tabela 22: Estatística descritiva de coqueiros (COQ) de piaçava amostrados no quilombo brejo grande, localizado no município de ituberá, bahia.

Tabela 23: Valores de correlação entre produção de fibra bruta de piaçava (PFB) e variáveis independentes (idade, H, NFA, DB e DAP) para bananeiras em produção (bp) amostradas em dois plantios de piaçava, localizados no estado da bahia.

Tabela 24: Valores de correlação entre produção de fibra bruta de piaçava (PFB) e variáveis independentes (idade, H, NFA, DB e DAP) para coqueiros (COQ) amostrados em dois plantios de piaçava, localizados no estado da bahia.

Tabela 25: Estatísticas dos parâmetros, medidas de precisão e validação das equações de regressão ajustadas para estimar pfb em piaçavas produtivas (PB e COQ), amostradas em dois plantios (AP e QUI), localizados no estado da bahia.

Tabela 26: Percentual de piaçavas por fase de desenvolvimento em cada parcela amostrada.

Tabela 27: $\mathrm{N}^{\circ}$ de piaçava por plantio e $\mathrm{n}^{\circ}$ de COQ e BP por plantio do quilombo brejo grande conforme levantamento realizado e informações dos extrativistas da piaçava

Tabela 28: Médias do $\mathrm{n}^{\circ}$ de plantas por hectare (ha) e $\mathrm{n}^{\circ}$ coqueiro, BP, BN, patioba, nos dois sistemas produtivos avaliados.

Tabela 29 - Estatísticas da produção de fibras com correspondentes valores de altura e número de folhas registradas em palmeiras piaçavas, fase bananeira em produção, em dois plantios localizados na bahia.

Tabela 30 - Estatísticas da produção de fibras com correspondentes valores de altura e número de folhas registradas em palmeiras piaçavas, fase coqueiro, em dois plantios localizados na bahia.

Tabela 31: Produção média de fibra $(\mathrm{kg})$ e número médio de folhas por fase de desenvolvimento no quilombo.

Tabela 32: Produção média de fibra vegetal no ciclo de 13 messes em plantas coq e bp do quilombo brejo grande de ituberá.

Tabela 33: Produção média de fibra e número de folhas por fase de desenvolvimento da piaçava e em cada parcela da propriedade particular de canavieiras. 91

Tabela 34: Produção média de fibra vegetal no ciclo de 15 meses em plantas coq e bp na propriedade.

Tabela 35: Delineamento experimental pré-beneficiamento e beneficiamento. 121

Tabela 36: Equipamentos necessários para produção de vassouras de piaçava e experimentos realizados em campo.

Tabela 37: Rendimentos em fibra vegetal, 'fitas', resíduo mensurado e resíduo real formado nos sistemas produtivos avaliados, etapa de pré-beneficiamento.

Tabela 38: Média do tempo de 'cata' da fibra vegetal da piaçava.

Tabela 39: Rendimentos em fibra vegetal cortada e resíduo real formado nos sistemas produtivos I, III e IV, etapa de beneficiamento.

Tabela 40: Média do tempo de seleção e corte da fibra vegetal da piaçava.

Tabela 41: Rendimentos em fibra vegetal fino-média, resíduo mensurado e resíduo real formado nos sistemas produtivos avaliados, etapa de confecção. 
Tabela 42: Quantidade média de vassouras por sistema produtivo analisado 154

Tabela 43: Tempo de confecção das vassouras de cepo com 18 furos 155

Tabela 44: Rendimento final do processamento da fibra vegetal em vassoura de piaçava.

Tabela 45: Valores praticados na bahia (2014), pagos aos extrativistas e preço de comercialização dos produtos gerados. 165

Tabela 46: Margem bruta ganho extrativista com a fibra bruta (2014)...................................... 166

Tabela 47: Margem bruta de ganho extrativista com fibra beneficiada (2014). 166

Tabela 48: Coeficientes técnicos do processamento dos pfnms oriundos da fibra vegetal bruta da piaçava da bahia. 169

Tabela 49: Preços do milheiro de frutos por região: nilo peçanha, ituberá e canavieiras. . 173

Tabela 50: Massa de epicarpo, mesocarpo, endocarpo e de sementes por fruto. 177 


\section{LISTA DE FIGURAS}

Figura 01: Municípios baianos com ocorrência da piaçava (attalea funifera mart.), fragmentos florestais remanescentes, terras indígenas e quilombos demarcados pela fundação palmares.

Figura 02: Mapa das comunidades quilombolas do município de ituberá, aqbgi é terceira de baixo para cima do mapa. Fonte: Teixeira Apud Silva (2013).

Figura 03: Palmeira de piaçava no pasto aberto (a) e capoeira em regeneração (b). 28

Figura 04: (A) Espata (busa), (b) inflorescência e (c) cachos de frutos da piaçava da bahia.

Figura 05: Fruto da piaçava: tamanho, aspectos externos e internos. ........................................... 30

Figura 06: Localização das áreas de implantação das 11 parcelas amostrais. .......................... 39

Figura 07: Plantios quilombolas de piaçava, localizados em ituberá, BA................................. 39

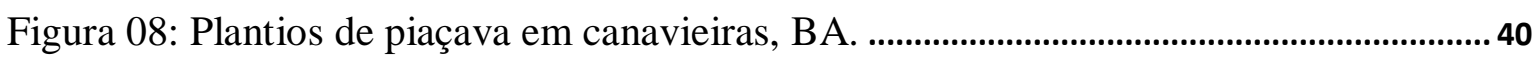

Figura 09: Mapa com alocação das parcelas dentro dos 50 hectares da propriedade............. 43

Figura 10: 'Tiragem da fibra vegetal' (a) e os 'mondongos' de fibra limpa e fibra bruta, respectivamente, amarrados (b).

Figura 11: 'Tirador' puxando a 'capa' (a), detalhes do 'toco' ainda na planta (b) e detalhes da 'capa' de fibra bruta já extraída, onde a parte mais clara corresponde a 'fita' e a mais escura as fibras vegetais (c).

Figura 12: Palmeira de piaçava muda ou patioba (a), bananeira nova (b) e bananeira em produção com a 'capa' de fibra bruta (c).

Figura 13: Mulher realizando a 'cata' da fibra da piaçava (a), equipamentos utilizadas 'escovas' e facão (b), pentes metálicos (c).

Figura 14: Pentes para cobertura, feitos com 'fita', subproduto da etapa de 'cata'. utilizado para cobertura de quiosques de praia.

Figura 15: Piaçavas danificadas: (a) palmeira morta por danos no 'olho'; (b) danos no estipe da palmeira 'pasmada' e detalhe da incisão feita no estipe da palmeira (c).

Figura 16: Incisões feitas com facão no estipe da palmeira em ituberá, bahia. .62

Figura 17: Extração com escoras de madeira em canavieiras, bahia.

Figura 18: Número de folhas abertas verdes (plantas saudáveis) por hectare registradasem palmeiras produtivas (bp e coq) de piaçavas em duas plantações(área particular e quilombola), localizadas no estado da bahia.

Figura 19: Número de folhas abertas secas (plantas saudáveis) por hectare registradas em palmeiras produtivas (bp e coq) de piaçavas em duas plantações (área particular e quilombola), localizadas no estado da bahia

Figura 20: Médias das variáveis HT, HE, DB, DAP, NFC e NFT, das palmeiras produtivas de piaçava (BP e COQ) amostradas em duas plantações (área particular - ap e quilombola qui), localizadas no estado da bahia.

Figura 21: 'Mondongos', feixes ou fardos de fibra bruta e 'mondogos' de fibra limpa....... 93 
Figura 22: Capas de piaçava jogadas no chão pelo extrator (a) e 'capas' esticadas pelo auxiliar para posterior formação dos fardos de fibras brutas (b).

Figura 23: Vias de acesso aos piaçavais: mata de piaçava (a), plantio (b) e vicinais (c)...... 94

Figura 24: Veículos utilizados para transporte da fibra vegetal: trator de rabeta (a), jumento e caminhão (b).

Figura 25: Vista de 'catadouros' familiares em canavieiras e ituberá, respectivamente. .......95

Figura 26: (A) Fardos e 'cabeças' formados na mata atlântica e (b) 'amarrio da fibra limpa no 'catadouro' e (c) finalização do fardo ('mondongo').

Figura 27: Armazenamento dos feixes de piaçava no 'catadouro' familiar do quilombola andré taraca assunção, Ituberá, Bahia.

Figura 28: Tubetes para mudas, produzidos com os resíduos de produção da vassoura de piaçava, cidade de nilo peçanha na casa familiar agroflorestal - CFAF.

Figura 29: Vassouras de piaçava: cepo de chita em madeira (a), cepo de metal (b), vassoura para limpeza urbana (c) e vassoura de pia e banheiro (d).

Figura 30: APL da piaçava, unidades de conservação e terras indígenas (2011)...................117

Fonte: MMA Apud Oliveira (2012)....

Figura 31: Localização dos empreendimentos avaliados na etapa de processamento da fibra vegetal e frutos da piaçava da bahia.

Figura 32: Etapas do processamento da fibra vegetal na confecção de vassouras de piaçava.

Figura 33: (A) Frutos da piaçava adequados para o aproveitamento da polpa do 'satim'; (b) fruto aberto e (c) detalhe de um fruto já consumido pela fauna silvestre. 128

Figura 34: (A) Retirada do pedúnculo, (b) lavagem e (c) pesagem dos 30 frutos selecionados aleatoriamente. 128

Figura 35: Materiais utilizados nos experimentos: balanças, raladores, facas e machadinha.

Figura 36: (A) Retirada da casca e (b) fibras grossas da polpa; e (c) extração do 'Satim' com ralador e (d) a polpa de 'satim'.

Figura 37: (A) Endocarpos dos frutos numerados; (b) extração das sementes de_Piaçava do interior do endocarpo e (c) sementes embaladas e numeradas. 130

Figura 38: Coleta dos frutos 'de vez' e maduros da piaçava. 131

Figura 39: (A) Fruto com casca externa e sem casca externa; (b) retirada da casca e polpa do fruto com machadinha e; (c) casca e polpa separada do endocarpo.

Figura 40: (A) e (B) extração manual das sementes da piaçava de dentro_do endocarpo ósseo com faca e (c) sementes já retiradas.

Figura 41: Artesanatos da fibra vegetal limpa da piaçava da bahia, cooprap (2013).......... 135

Figura 42: Fluxograma dos PFNMs oriundos da palmeira da piaçava da bahia. 124

Figura 43: Grampeadora e prensa manual ou de pedal, equipamentos produzidos por ferreiros locais, unidades produtivas da (a) cooprap e da (b) coopafbasul 142 
Figura 44: (A) Grampeadora automática e (b) prensa pneumática produzida pela empresa pozzi máquinas. Fonte: Marcado Livre.

Figura 45: 'Cata' manual das fibras brutas da piaçava, canavieiras e ituberá, Bahia ............ 144

Figura 46: 'Pentes' utilizados no pré-beneficiamento da fibra bruta de piaçava.

Figura 46: Equipamentos de corte da fibra: (a) guilhotina manual, (b) elétrica e (c) facão.

Figura 47: Seleção manual das fibras finas, médias e grossas na COOPRAP(Nilo Peçanha) e 'catadouro do Hamilton (Ituberá).

Figura 48: 'Pentes Metálicos' utilizados no beneficiamento da fibra limpa da piaçava. ...... 148

Figura 49: (A) Vassourão de cepo de madeira; (b) vassoura redonda; (c) vassoura de chita de cepo em madeira, (d) vassoura de chapa de alumínio e (e) plástico; e (f) vassouras de pia. todas confeccionadas com a fibra vegetal da piaçava.

151

Figura 50: Máquina para fixar a fibra vegetal no cepo da vassoura, denominada de grampeadora Ou 'Pica-Pau'.

Figura 51: (A) Vassouras de cepo de madeira com 18 furos; (b) 'tufo' de fibras quebradas; e (c) vassourão da piaçava da bahia com fibras grossas.

Figura 52: (A) Feixes de fibra vegetal limpa; (b) feixes de fibras cortadas; (c) fibras cortadas e embaladas e (d) vassouras de pia e vassourões de piaçava, armazenadas nas unidades produtivas. 158

Figura 53: Vassoura de cepo de plástico para limpeza urbana, comercializada nas redes de supermercados de Aracaju, Sergipe (2014) 159

Figura 54: Quantidade produzida e valores comercializados em dólar (us\$) nos municípios de Ituberá, Nilo Peçanha E Canavieiras. Fonte: IBGE (2004-2013). 160

Figura 55: Quantidade de fibra bruta produzida e valores comercializados em dólar (us\$) nos municípios de Ituberá, Nilo Peçanha E Canavieiras. Fonte: IBGE (2004-20013) ........ 161

Figura 56: Valores em dólar (US\$) da exportação da fibra vegetal, via salvador, Bahia, nos anos de 2007 a 2014. Fonte: Aliceweb, 2015.

Figura 57: Fluxograma dos caminhos da fibra vegetal da piaçava da bahia Estados de São Paulo (SP), Rio de Janeiro (RJ) e Espírito Santo (ES).

Figura 58: (A) Equipamento (esmeril) de lixar o endocarpo do fruto e (b) biojóias do Quilombo e (c) anel do endocarpo da piaçava.

Figura 59: Fruto da piaçava com epicarpo (a), mesocarpo (b), endocarpo (c) e sementes do fruto da piaçava $(\mathrm{d})$.

Figura 60: (A) Frutos maduros, (b) descascados, (c) ralados e (d) polpa do 'satim'. 175

Figura 61: Aproveitamento da polpa do 'satim' para fazer o mingau tradicional. 176

Figura 62: (A) Sementes 'de vez' inteiras e (b) sementes maduras picadas Pós-Secagem, antes da extração do óleo vegetal.

Figura 63: Óleo Vegetal da piaçava: (a) são amostras das sementes 'de vez' e (b) são amostras com óleo das sementes maduras. 179

Figura 64: (A) Cacho de fruto da piaçava mirim, (b) frutos fechado, (c) um fruto aberto, (d) início da germinação das sementes, (e) separação do endocarpo e (f) mesocarpo e polpa.180 
Figura 65: Piaçavas mirins no sub-bosque da mata e plantio de eucalipto.

Figura 66: (A) Folha do 'olho', (b) folha parcialmente fechada extraída e (c) corte manual dos folíolos "despenca das palhas" após a extração, ainda em campo.

182

Figura 67: (A) Cozimento dos folíolos novos, (b) e (c) tingimento natural com cipó de rego, (d) folíolos tingidos com urucum.

Figura 68: (A) Abertura dos folíolos pós-cozimento na coloração natural; (b) feixe formado após o cozimento; e (c) feixes ou "rodas da palha" da piaçava mirim secas.

Figura 69: (A) São folíolos brutos, linha de licuri (verde) e tiras de piaçava; (b) trançado com as tiras de piaçava; (c) 'braça' das tiras trançadas sendo utilizadas para confeccionar um chapéu da palha da piaçava.

Figura 70: Bolsas, trançados e cestos com a folha da piaçava mirim confeccionados pelas extrativistas de Massarandupió 


\section{LISTA DE SÍMBOLOS, NOMEMCLATURAS E ABREVIAÇÕES}

AQBGI - Associação Quilombola do Brejo Grande de Ituberá

APA - Área de Proteção Ambiental

APL - Arranjo Produtivo Local

AACAF - Agência e Agronegócio e Comercialização dos Agricultores Familiares

BUSA - forma popular de se referir à inflorescência da piaçava

${ }^{\circ} \mathbf{C}$ - Graus Celsius

CEPLAC - Comissão executiva do Plano da Lavoura Cacaueira

CFAF - Casa Familiar Agroflorestal

CONAB - Companhia Nacional de Abastecimento

COOPAFBASUL - Cooperativa dos Agricultores Familiares do Baixo Sul da Bahia COOPRAP - Cooperativa das Produtoras e Produtores Rurais da APA do Pratigi

EBDA - Empresa Baiana de Desenvolvimento Agrário

EVA - Etileno Acetato de Vinila

FCP - Fundação Cultural Palmares

FUNAI - Fundação Nacional do Índio

GPS - Sistema de posicionamento global (global positioning system)

g-grama

Ha - Hectare

IBGE - Instituto Brasileiro de Geografia e Estatística

IDES - Instituto de Desenvolvimento Sustentável do Baixo Sul da Bahia

IDH - Índice de Desenvolvimento Humano

INCRA - Instituto Nacional de Colonização e Reforma Agrária

INPI - Instituto Nacional de Propriedade Industrial

Kg - Quilo Grama

m - Metros

$\min -$ Minutos 
MMA - Ministério do Meio Ambiente

MDA - Ministério do Desenvolvimento Agrário

MDS - Ministério do Desenvolvimento Social

MPa - Megapascal

PFNMs - Produtos Florestais Não Madeireiros

PGPMBio - Política de Garantia de Preço Mínimo para os Produtos da Sociobiodiversidade

PNUD - Programa das Nações Unidas para o Desenvolvimento

PMCF - Plano de Manejo Comunitário

UFS - Universidade Federal de Sergipe

UFRB - Universidade Federal do Recôncavo da Bahia

UnB - Universidade de Brasília

US\$ - Dólar dos Estados Unidos (United states dollar)

R\$ - Real é a moeda corrente no Brasil

SEAGRI - Superintendência de Estado para Agricultura Familiar da Bahia

INGA - Instituto de Gestão das Águas

IDH - Índice de Desenvolvimento Humano

SEPLAN - Secretaria de Estado de Planejamento da Bahia

SEDIR - Secretaria de Desenvolvimento e Integração Regional

SFB - Serviço Florestal Brasileiro

SPI - Serviço de Proteção ao Índio

T.I. - Terra Indígena

TGA - Método de análise termogravimétrica

T.S.- Tecnologia Social 


\section{INTRODUÇÃO GERAL}

A piaçava (Attalea funifera Mart) da Bahia é uma palmeira endêmica da restinga ${ }^{1}$ que fornece uma fibra vegetal resistente, frutos e folhas em abundância. Além da sua fundamental importância para conservação de remanescentes florestais da restinga, a piaçava é um produto florestal não madeireiro (PFNM) de grande valor socioeconômico no Brasil.

A fibra vegetal da piaçava ocupa a $5^{\circ}$ posição entre os PFNMs brasileiros mais comercializados, com valor da produção estimada em $\mathrm{R} \$$ 82,9 milhões de reais no ano de 2013 , correspondente a 44.617 toneladas $^{2}(114.167 \mathrm{~kg})$, com decréscimo de $22,8 \%$ quando comparada aos valores de 2012 (57.462 toneladas), devido à baixa procura pelo produto. Em 2013 o valor de produção dos coquinhos de açaí alcançou $\mathrm{R}$ \$ 409,7 milhões de reais $\left(1^{\mathrm{a}}\right)$; erva-mate nativa $\mathrm{R} \$ 400$ milhões $\left(2^{\mathrm{a}}\right)$; amêndoas de babaçu $\mathrm{R} \$ 121,8$ milhões ( $\left.3^{\mathrm{a}}\right)$; pó de carnaúba 118 milhões (4a); fibras de piaçava ao montante de $\mathrm{R} \$ 82,9$ milhões $\left(5^{\mathrm{a}}\right)$ e castanha-do-pará $\mathrm{R} \$ 72,1$ milhões $\left(6^{\mathrm{a}}\right)$. Juntos, esses produtos somaram 92,6\% do valor total da produção extrativista vegetal não madeireira do Brasil. Neste grupo de produtos apenas a fibra vegetal da piaçava está relacionado ao Bioma Mata Atlântica. O buriti e a carnaúba também fornecem fibras vegetais e, em 2013, foram comercializadas 2.317 toneladas de carnaúba e 466 toneladas de buriti (IBGE, 2013).

O estado da Bahia é o maior produtor de fibras vegetais da piaçava, com destaque para municípios de Ilhéus, Nilo Peçanha, Cairu, Ituberá e Canavieiras, esses foram responsáveis por $85,5 \%$ da produção de piaçava nacional no ano de 2013. A piaçava do amazonas, Leopoldina piassaba Wallace, também contribui com a produção nacional de piaçava, sendo responsável por 2,2 \% da produção nacional (IBGE, 2013). Parte dessa produção foi exportada para Alemanha, Bélgica, Reino Unido, Itália e Portugal no ano de 2014 via Salvador, Bahia, a quantidade anual foi de $114.167 \mathrm{~kg}$ (114 toneladas) de feixes de fibras vegetal para entrançar, utilizadas na fabricação de vassouras, escovas e pinceis e artigos semelhantes (ALICEWEB, 2015).

A fibra vegetal é o principal PFNM oriundo da piaçava da Bahia, porém é possível o aproveitamento dos frutos da planta: como alimento da polpa e óleo vegetal das sementes, além dos artesanatos com o endocarpo do fruto e potencial para produção de carvão ativado. Segundo Bondar (1942a), toneladas dos cocos da Attalea foram

\footnotetext{
${ }^{1}$ Ecossistema associado ao Bioma Mata Atlântica

${ }^{2}$ Uma tonelada (Ton) é igual a 1.000 quilogramas (Kg).
} 
exportadas, durante a primeira guerra mundial, para serem transformados em carvão ativado e utilizados nas máscaras de gás. Os frutos também são utilizados para a produção de mudas para os plantios, enriquecimento e reposição de plantas nas áreas já formadas. Esses também podem ser utilizados como carvão vegetal (BONDAR 1942a; GUIMARÃES; SILVA, 2012;). Com relação aos produtos oriundos do fruto da piaçava, somente os artesanatos do endocarpo, frutos in natura e mudas de piaçava foram encontrados no mercado local, regional e nacional.

A palmeira de piaçava é uma espécie secundaria inicial na sucessão florestal, então clareiras abertas naturalmente, ou não, são rapidamente colonizadas por palmeiras de piaçava na zona de ocorrência natural da piaçava. Uma mesma palmeira poderá ser explorada ao longo de mais de 30 anos, sem findar sua produção de fibra vegetal.

A variedade da piaçava coqueiro tem uma longevidade maior do que oitenta anos, conforme claramente colocado pelos extrativistas no sul da Bahia. A outra variedade de piaçava mirim que ocorre no norte do estado da Bahia apresenta fibras mais finas, essas não são exploradas economicamente, as plantas também são longevas, porém não apresentam grande porte e não forma estipe.

Esta pesquisa de doutorado trata do extrativismo tradicional da piaçava da Bahia, variedade coqueiro, da região sul da costa da Bahia. São abordados os aspectos tradicionais do extrativismo da piaçava, o manejo florestal da fibra bruta da piaçava, o prébeneficiamento, o beneficiamento e a confecção das vassouras com as fibras vegetais da piaçava coqueiro.

O manejo florestal da Mata Atlântica com piaçava e também o manejo dos piaçavais formados nas áreas de Mata Atlântica, são realizados pelos agroextrativistas quilombolas, pescadores, agricultores familiares e especialistas na extração da fibra. Essas pessoas realizam todas as atividades de manejo, normalmente executam esse trabalho para os médios e grandes produtores como 'meeiros', onde 50\% do valor de fibra limpa pertencem aos agroextrativistas e 50\% aos donos da terra. Os extrativistas também podem ser remunerados pelos médios e grandes produtores. Outra prática na região é a remuneração por diária aos extratores especialistas, ou seja, o trabalhador recebe uma diária, com valor fixo, independente da quantidade extraída somente alguns extratores tem esse poder de barganha no mercado. A extração é uma atividade genuinamente masculina.

O pré-beneficiamento da fibra bruta vegetal é realizado, principalmente, pelas mulheres em 'catadouros familiares', localizados, normalmente, em quilombos e assentamentos da região, na periferia das cidades do sul da Bahia e em alguns galpões com 
maior capacidade produtiva. O beneficiamento da fibra limpa é realizado comumente por homens que separam, limpam e cortam as fibras, conforme especificações do mercado. Esses fardos de fibras cortadas são comercializados com atravessadores que repassam para fábricas de vassouras nos estados de São Paulo, Rio de Janeiro, Espírito Santo, entre outros, onde é realizada a confecção das vassouras de piaçava ou encaminhada para exportação.

Portanto, a mesma fibra vegetal, extraída de uma palmeira, passa por no mínimo oito trabalhadores, cada um deles executando especificamente sua função ${ }^{3}$, para confecção da vassoura de piaçava. As peças artesanais, feitas com a fibra limpa e palha da costa, envolvem menos profissionais no processamento das mesmas.

Apesar da importância desta espécie para conservação de remanescentes florestais da restinga, na geração de renda das famílias agroextrativista e uso histórico de seus produtos, não houve avanços em políticas públicas que refletissem de forma permanente a melhoria de renda e continuidade no processo de capacitação da mão de obra. As instituições de pesquisa também não conseguiram promover avanços na criação de novos produtos e consequentemente estimulo ao desenvolvimento local e regional.

O governo federal incluiu, no ano de 2009, a fibra piaçava da Bahia no Plano Nacional de Promoção das Cadeias de Produtos da Sociobiodiversidade, ação executada pelo Ministério do Meio Ambiente (DEX/SEDR/MMA/MDA/MDS), em parceria com a Companhia Nacional de Abastecimento (CONAB). Os principais resultados observados desta ação foram à concepção do Arranjo Produtivo Local (APL) da piaçava nos municípios do Baixo Sul Baiano (Nilo Peçanha, Ituberá, Valença, Taperoá, Cairu, Camamu, Maraú e Igrapiúna) e a implantação da Política de Garantia de Preços Mínimos para Produtos da Sociobiodiversidade - PGPMBio da CONAB (MMA, 2010).

De uma forma geral, para a maioria das espécies brasileiras com potencial não madeireiro, as atividades de manejo e beneficiamento para obtenção de polpas, castanhas, palmitos, óleos vegetais, exsudados, entre outros produtos, de uma gama de espécies de origem brasileira são realizadas por meio do processo de tentativa e erro. A experimentação realizada por comunidades locais está associada ao uso tradicional dos recursos florestais para subsistência e geração de renda. Portanto, acredita-se que sistematizar o conhecimento tradicional adquirido pelas comunidades locais e relacioná-lo

\footnotetext{
${ }^{3}$ Extrator (tirador) tem a função de subir na palmeira e extrair as fibras vegetais brutas; o amarrador tem função de juntar as fibras extraídas e formar os feixes de $15 \mathrm{~kg}$ (uma arroba) de fibra bruta; outra pessoa é responsável pelo transporte; extrativista que faz a separação e limpeza inicial (cata); limpeza e corte; atravessador; operadores da confecção da vassoura.
} 
com algumas pesquisas científicas disponíveis sobre os PFNMs, possa viabilizar a proposição de novos processos, técnicas e tecnologias que agreguem ainda mais eficiência ao processo produtivo, do manejo ao beneficiamento.

Entende-se que produtos florestais não madeireiros são todos aqueles oriundos de vegetação nativa, enriquecimento florestal, agroflorestas, plantios consorciados ou puros da espécie potencial, que podem ser comestíveis, medicinais, artesanatos, utensílios variados, matéria prima para construção de casas e princípios ativo de uma infinidade de produtos industrializados. São extraídos de plantas (árvores, arbustos, palmeiras e ervas), utilizados conforme a parte aproveitada, raiz, folha, flor, fruto, fibras, cascas, resinas, látex, óleos (vegetais e essenciais), galhos, estipe e tronco.

O presente estudo tem como principal finalidade examinar detalhadamente as questões relacionadas ao extrativismo sustentável da palmeira de piaçava da Bahia. Para isto, foram consideradas duas áreas distintas das Ciências Florestais: o manejo florestal e o processamento dos produtos florestais não madeireiros (PFNMs). Ambos foram abordados, considerando critérios distintos, respeitando a diversidade do fazer tradicional dos atores locais, bem como observações de campo, mensurações e ensaios técnicos científicos. Ao mesmo tempo em que se distingue, apresentando o estado da arte do aproveitamento da piaçava, dentro da área de tecnologia de produtos florestais, não pretendendo esgotar o conhecimento do manejo florestal não madeireiro e questões étnicas relacionadas às comunidades quilombolas extrativistas da Bahia.

Este trabalho é uma peça importante para apoiar tomadas de decisões quanto às técnicas e tecnologias empregadas na cadeia produtiva do extrativismo da piaçava, modelos produtivos inovadores e apresenta o saber das comunidades tradicionais e agroextrativistas da região, relacionados ao aproveitamento dos PFNMs desta palmeira da Mata Atlântica.

Portanto, a realização deste estudo é justificada pelo fato dos produtos oriundos da piaçava representarem uma parcela significativa da renda familiar de muitas comunidades tradicionais da Bahia. Ressalta-se a importância de se estimular essa importante atividade produtiva que fixa as comunidades com dignidade em seus territórios, valorizando as práticas culturais relacionadas aos PFNMs. O estudo fornece índices importantes para os extrativistas que quiserem elevar o aproveitamento da fibra bruta ao longo das etapas de produção e agregar valor ao produto final. Esse trabalho também apresenta dados primários, específicos sobre o aproveitamento dos frutos, informações ainda não 
disponibilizadas na literatura científica, além da descrição das técnicas de aproveitamento das palhas da piaçava acaule (piaçava mirim) da Bahia.

O primeiro capítulo trata do manejo florestal da piaçava, apresenta o significado dos termos tradicionais adotados pelos extrativistas, técnicas e tecnologias de manejo, estoque produtivo, produtividade por palmeira e modelo para estimar a produtividade por planta

No capítulo dois é detalhado o processamento da fibra vegetal da piaçava da Bahia, apota coeficientes técnicos de rendimento da fibra vegetal e apresenta dados preliminares do aproveitamento dos frutos da piaçava da Bahia.

\section{OBJETIVO GERAL}

O objetivo geral foi apresentar uma visão sistêmica da cadeia produtiva do extrativismo sustentável da piaçava da Bahia (Attalea funifera Mart.), mais especificamente registrar, resgatar e analisar as técnicas e tecnológicas empregadas no processo produtivo da fibra de piaçava em duas regiões distintas, Costa do Dendê e Costa do Cacau, ambas no sul do estado da Bahia, Brasil. Essas informações tem a finalidade valorizar as técnicas tradicionais já praticadas, correlacionar as etapas produtivas, bem como apresentar novas informações, geradas no âmbito desta pesquisa, que aprimore essa atividade produtiva. Apresenta uma visão interdisciplinar do extrativismo tradicional da piaçava, vislumbra um possível aproveitamento integral da espécie e fortalece a linha de pesquisa dos PFNMs do Brasil.

\section{HIPÓTESE}

O domínio das etapas de produção, manejo e aproveitamento da fibra vegetal da piaçava, realizado pelos extrativistas, agrega valor ao produto final e eleva a renda dos quilombolas e pequenos agroextrativistas residentes da região endêmica da palmeira Attalea funifera. 
CAPÍTULO 1 - MANEJO DA FIBRA DE PIAÇAVA (Attalea funifera Mart.) NO QUILOMBO BREJO GRANDE ITUBERÀ E PRODUTOR DE CANAVIEIRAS - BAHIA 


\section{1 - INTRODUÇÃO}

O manejo florestal de produtos florestais não madeireiros - PFNMs praticado por comunidades tradicionais através dos conhecimentos acumulados há várias gerações e transmitidos de forma oral entre grupos de ribeirinhos, seringueiros, sertanejos, caiçaras, quilombolas e indígenas, entre outras comunidades é feito através de experimentações práticas. Esse uso tradicional ainda é pouco estudado e sistematizado, mas observa-se que espécies de grande potencial para determinadas comunidades, mesmo utilizadas de forma intensa ao longo do tempo, devido às suas propriedades medicinais e/ou por ser um complemento alimentar importante na dieta das comunidades, vem sendo preservadas por várias gerações. Essas espécies são propagadas, multiplicadas, conservadas, conforme a intensidade de manejo e o interesse das comunidades agroextrativistas em relação aos seus produtos não madeireiros. O uso pode ser de subsistência e/ou comercial modificando a escala e organização do manejo florestal praticado.

Principalmente quando o manejo florestal de PFNMs atinge escala comercial deve primar pela melhora na produtividade do PFNM foco por área e por espécie, sempre prezando pela equidade de distribuição das margens de ganhos entre os atores agroextrativistas da cadeia produtiva e a conservação do ambiente onde a espécie naturalmente se desenvolve, bem como manter a variabilidade genética da espécie aproveitada.

E para tanto é importante destacar que as técnicas de manejo e tecnologias utilizadas variam conforme a escala de comercialização do PFNM e não menos importante, à parte da planta utilizada. Quando o aproveitamento se tratar das raízes, palmitos, flores e frutos, o manejo florestal é mais intensificado. Por outro lado, quando o uso for os exsudatos (resinas, látex entre outras substâncias), folhas e fibras, o manejo florestal poderá ser de menor complexidade, conforme mencionou Machado (2008).

O manejo florestal para ser sustentável deve ser feito com critérios técnicos e tecnológicos que evitem, principalmente, a sobre exploração da espécie florestal foco. Esses critérios técnicos e tecnológicos devem ser definidos e aprimorados através de um diálogo continuo entre o saber formal e o saber tradicional, onde o conhecimento científico busca incorporar o saber popular na construção de soluções e inovações.

No caso específico da piaçava da Bahia (Attalea funifera Mart.), o manejo desta espécie é uma herança cultural atribuída aos índios tupinambás, que utilizavam o trançado para fabricar diversos objetos. Essa herança foi repassada às outras comunidades 
tradicionais como quilombolas e pescadores, e, posteriormente, aos agricultores familiares que vivem nas áreas de ocorrência natural da espécie. Esses agroextrativistas vêm aproveitando as fibras vegetais da piaçava para seu consumo próprio, produzindo cordas, cobertura de casas, chapéus e tapetes. Os dois últimos são geralmente confeccionados com a folha da piaçava pelas mulheres dessas comunidades.

As fibras da piaçava vêm sendo comercializadas desde o período colonial, após o descobrimento do Brasil. Naquela época, as fibras eram procuradas por navegadores de várias nacionalidades para fabricação de cordas que eram utilizadas como amarra de navios por oferecerem mais segurança às embarcações (BARRETO, 2009).

É importante destacar que, no sul da Bahia, grandes áreas de ocorrência natural da espécie que eram anteriormente ocupadas pelas comunidades indígenas e, posteriormente, pelas populações negras, remanescentes de quilombos, atualmente estão nas mãos de grandes empresários, proprietários de terras e indústria do turismo. Esses novos proprietários e produtores de piaçava adquiriram grandes áreas de ocorrência natural de piaçava em Camamu, Boipeba, Nilo Peçanha, Ituberá, Itacaré, Olivença, Canavieiras, entre outros municípios. Tais proprietários fizeram o enriquecimento nas áreas onde a planta já ocorria e também implantaram novos plantios, próximo às áreas de ocorrência natural. Esse modelo também foi adotado por quilombolas e assentados de reforma agrária em áreas de menor dimensão.

A piaçava da Bahia é endêmica, ou seja, de ocorrência restrita, encontrada predominantemente na zona de transição entre a restinga e a mata higrófila (ambas associadas ao Bioma Mata Atlântica), sobre os tabuleiros próximos ao litoral (SILVA, 2002). Contudo, os estudos que apresentaram o mapeamento das áreas de ocorrência desta espécie não são precisos quanto ao tamanho da área de ocorrência (Anexo IV) na Zona Costeira da Bahia, Sergipe e Alagoas (BONDAR, 1942; SILVA, 1975; GLASSMAN, 1999; e LORENZI, 2010). Além disso, as informações não são precisas quanto às categorias de uso do território, o nível de conservação da vegetação associada, sobre a situação das unidades territoriais e a situação dos conflitos de terra existentes na região.

Guimarães e Silva (2012) afirmam que a piaçava é encontrada com maior frequência no litoral sul e no Recôncavo, norte de Valença até ao sul do Rio Corumbau, no município de Prado, sempre bem próximo à costa. Ainda, segundo esses autores a vegetação ocorre de forma esparsa até uma distância de $60 \mathrm{~km}$ ao oeste, em direção ao interior, e, essa distribuição da vegetação ocorre devido à umidade e o calor das zonas litorâneas e, também, devido aos solos arenosos e permeáveis da região. As piaçavas 
encontradas no norte da Bahia, Sergipe e Alagoas são acaules e com baixa produção de fibras. As extrativistas da comunidade de Massarandupió (BA) conhece essa variedade de piaçava como sendo a piaçava mirim.

Segundo IBGE (2013), os principais municípios baianos, produtores de fibra vegetal da piaçava, são: Ilhéus, Nilo Peçanha, Cairu, Ituberá, Taperoá, Canavieiras, Valença, Camamu, Santa Luzia, Maragogipe, Igrapiúna, Cachoeira, Maraú, Jaguaripe, Una, Itacaré e Nazaré. Portanto esses municípios compõem a zona de ocorrência natural da piaçava da Bahia, da linha do mar até $60 \mathrm{~km}$ em direção ao interior do estado.

Considerando esses estudos, mapas, informações e os mapas de ocupação e uso dos solos, cedidos pela Secretaria do Meio Ambiente do Estado da Bahia ${ }^{4}$ elaborou-se o mapa de ocorrência da piaçava da Bahia (Figura 01), desconsiderando a variedade de piaçava mirim, acaule, do norte do estado da Bahia. É importante destacar que os dados de alguns quilombos certificados da região ainda não foram disponibilizados e, portanto, não estão ilustrados neste mapa.

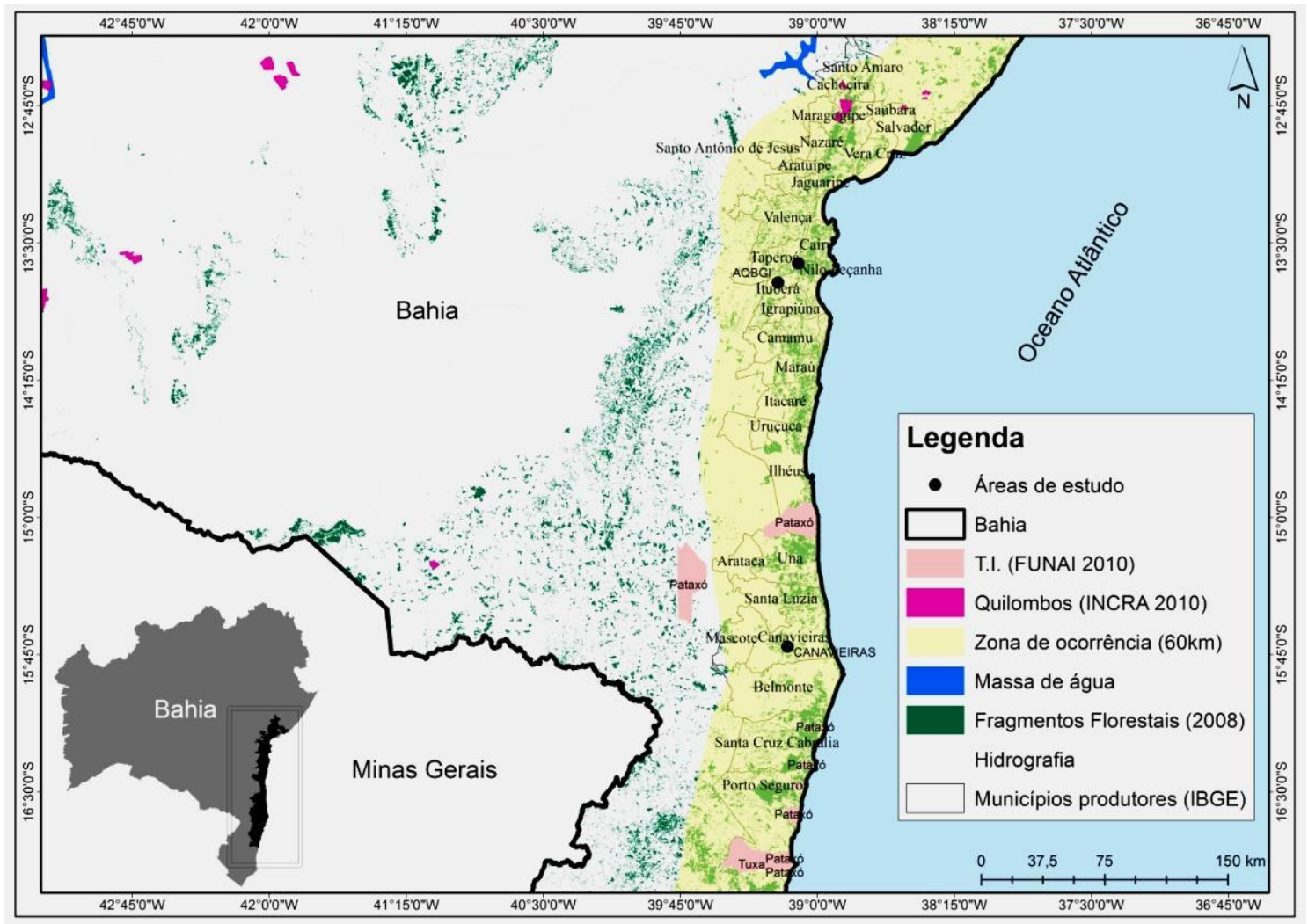

FIGURA 01: Municípios baianos com ocorrência da piaçava (Attalea funifera Mart.), fragmentos florestais remanescentes, terras indígenas e quilombos demarcados pela Fundação Palmares.

${ }^{4}$ Governo do Estado da Bahia, Secretaria do Meio Ambiente - SEMA, Superintendente de Estudos e Pesquisas Ambientais, Sr. Luiz Ferraro. 
As áreas de ocorrência natural da piaçava da Bahia, ao longo da Costa do Dendê e do Cacau, pertencem aos grandes proprietários (produtores rurais, redes turísticas e empresas); uma pequena parte são terras indígenas demarcadas ou em processo de demarcação; outra pequena parte pertence aos quilombos já certificados pela Fundação Cultural Palmares - FCP, entre 2004 e 2010 e em processo de demarcação e titulação pelo Instituto Nacional de Colonização e Reforma Agrária - INCRA. Ressalta-se que as áreas que estão ocupadas por povos indígenas e quilombos estão bem aquém das necessidades para reprodução física e cultural dessas comunidades, além de serem muito inferior às áreas ocupadas pelos grandes proprietários.

Os médios e pequenos produtores de piaçava, entre eles agricultores familiares e comunidades tradicionais, aqui considerados como agroextrativistas da piaçava, foram ocupando e adquirindo pequenas áreas de terra localizadas mais a oeste da Bahia (áreas interioranas) e adotaram a estratégia de formação de pequenos roçados de piaçava, também denominados de matas de piaçava ou 'reboleiras' de piaçava, consorciadas inicialmente com a mandioca e, posteriormente, com cacau, seringa e cupuaçu. Esses produtores adquiriam os frutos da piaçava, isto é, o material reprodutivo, em áreas de ocorrência natural da espécie.

Produtores e extrativistas tradicionais de piaçava afirmam que os plantios mais antigos foram formados por volta de 1940 e 1950, a mais de 50 a 60 anos atrás. É importante ressaltar que os reflorestamentos, sejam povoamentos pequenos, médios e grandes da espécie estão localizados nas áreas de ocorrência natural da espécie ou bem próximos a essas áreas.

Quilombolas e indígenas ainda praticam o manejo tradicional da piaçava tanto nas áreas dos grandes proprietários, quanto nas áreas de médios e pequenos proprietários e nas suas próprias áreas. Os agricultores familiares também realizam o extrativismo da piaçava e dominam o manejo tradicional da piaçava. Em geral, os grandes produtores contratam extrativistas especialistas em manejo e extração das fibras (agricultores familiares, quilombolas, indígenas), os quais são da região e localmente chamados de 'tiradores'. A extração da fibra bruta da piaçava é a atividade que oferece maior risco a saúde e segurança do trabalhador, devido à altura das palmeiras e a presença de animais peçonhentos no cálice da palmeira.

Diante dessa realidade onde o manejo florestal da piaçava é feito de forma empírica pelos extrativistas e, reconhecendo a relevância de sistematizar informações quanto ao manejo tradicional da espécie, a tese apresenta contribuições quanto ao estado da arte do 
extrativismo não madeireiro da piaçava da Bahia; parâmetros quantitativos e qualitativos que devem ser considerados durante a extração da fibra vegetal da piaçava; apresenta uma estimativa do potencial produtivo de dois plantios de piaçava, bem como a produção média por indivíduo explorado em cada plantio; aponta os gargalos do processo produtivo, especialmente na etapa de manejo da espécie e indica o tempo médio gasto pelo extrativista nas atividades de extração e manejo da piaçava. A produtividade do plantio é uma variável importante para gestão da atividade produtiva da piaçava que deve ser mensurada de forma simples e mais precisa possível.

\subsection{1 - Hipótese Manejo Florestal da Piaçava}

Acredita-se que métodos de mensuração do estoque do recurso, adaptados a realidade local, são ferramentas importantes para o manejo florestal da piaçava. A mensuração de índices de produtividade, por estágio de desenvolvimento da palmeira, contribui para organização da atividade produtiva como um todo, da mata ao produto florestal não madeireiro final.

\section{2 - OBJETIVOS}

Determinar e comparar os coeficientes técnicos do manejo florestal relativo à extração da fibra vegetal bruta da piaçava da Bahia (Attalea funifera Mart.), praticados pela comunidade quilombola de Ituberá e pela propriedade particular de Canavieiras. A principal finalidade destas informações é apresentar aos extrativistas uma visão geral das etapas, mensurar os estoques produtivos das áreas e produtividade por planta, bem como contribuir com novas metodologias, dados, informações para linha de pesquisa no campo do manejo florestal dos PFNMs.

\subsection{1 - Objetivos Específicos}

(a) Descrever e sistematizar as práticas de manejo extrativista da piaçava, em duas regiões distintas e, em dois sistemas produtivos diferenciados, quilombola e produtor particular;

(b) Quantificar o potencial produtivo dos plantios quilombolas e do produtor particular em duas áreas distintas de piaçava; 
(c) Mensurar tempo médio gasto na extração das fibras brutas por planta nos plantios quilombolas e produtor particular;

(d) Mensurar as perdas de palmeiras durante a etapa de extração da fibra vegetal bruta nos plantios quilombolas e produtor particular;

(e) Propor aos membros das comunidades tradicionais, uma metodologia acessível que permita a quantificação dos estoques produtivos de piaçava

\section{3 - REVISÃO DE LITERATURA}

\subsection{1 - Ocupação Mata Atlântica e o Extrativismo de PFNMs}

A Mata Atlântica é formada por um conjunto de formações florestais (Floresta Ombrófila Densa, Floresta Ombrófila Mista, Floresta Estacional Semidecidual, Floresta Estacional Decidual e Floresta Ombrófila Aberta) e de ecossistemas associados como as restingas, manguezais e campos de altitude, que se estendiam originalmente por aproximadamente $1.300 .000 \mathrm{~km}^{2}$, ao longo de 17 estados do território brasileiro (CAMPANILI; SCHAFFER, 2010).

Hoje, os remanescentes dessa vegetação nativa estão reduzidos à cerca de $22 \%$ de sua cobertura original e encontram-se em diferentes estágios de regeneração. Apenas cerca de $7 \%$ deste total encontram-se bem conservados em fragmentos maiores que 100 hectares (CAMPANILI; SCHAFFER, 2010). Mesmo estando bastante reduzida e fragmentada e com mais de 500 anos de exploração, estima-se que a riqueza florística atual na Mata Atlântica esteja em torno de 20.000 espécies vegetais, das quais 35\% das espécies existentes no Brasil. Entre estas espécies, muitas são endêmicas e ameaçadas de extinção. Em relação à fauna, estima-se que a Mata Atlântica abriga cerca de 850 espécies de aves, 370 espécies de anfíbios, 200 espécies de répteis, 270 espécies de mamíferos e 350 espécies de peixes (CAMPANILI; SCHAFFER, 2010).

A Mata Atlântica, que é um dos biomas mais ricos do mundo em biodiversidade, tem importância vital para aproximadamente 120 milhões de brasileiros que vivem na sua área de abrangência e é responsável por cerca de $70 \%$ do PIB nacional, além de prestar importantíssimos serviços ambientais (MMA, 2010).

$\mathrm{Na}$ Bahia, a Mata Atlântica originalmente ocupava 33,25\% do total do território do estado (MMA, 2010) e se distribuída por cinco regiões distintas: Chapada da Diamantina e encraves florestais do Oeste, Litoral Norte, Baixo Sul (Costa do Dendê), Sul (Costa do 
Cacau) e Extremo-Sul (Costa do Descobrimento). As três últimas regiões situam-se ao sul da Baía de Todos os Santos no Corredor Central da Mata Atlântica (CCMA).

Cada região da Bahia, com domínio da Mata Atlântica, é bastante diferente no que se refere às características ecológicas dos sítios (locais), forma de uso e ocupação dos solos, pressões antrópicas, história de ocupação humana, dentre outros aspectos ligados à economia local e regional. Historicamente, o Estado da Bahia foi submetido a diversos ciclos produtivos e econômicos que se estenderam nas áreas de domínio da Mata Atlântica. Dentre eles destacam-se: exploração do pau-brasil, cana de açúcar, ouro, diamantes, café, jacarandá, gado, algodão, cacau consorciado com seringueira, cravo da índia e mais recentemente a monocultura do eucalipto.

Em termos populacionais relacionados à Mata Atlântica, o estado da Bahia é o terceiro estado em número de habitantes neste Bioma, ficando atrás somente de São Paulo e Minas Gerais, com pouco mais de 11,3 milhões de habitantes distribuídos em 307 municípios (MMA, 2010).

Parte dessa área, coberta por Mata Atlântica baiana, são encontradas as áreas extrativistas formadas por piaçavas, que são exploradas por agricultores familiares, comunidades quilombolas, indígenas, grandes e médios produtores locais.

O extrativismo florestal na Mata Atlântica é uma atividade produtiva antiga, praticada antes mesmo da agricultura, por povos indígenas, e posteriormente por comunidades tradicionais, que utilizavam os recursos naturais disponíveis, encontrados nos ecossistemas associados onde residiam. Estes recursos serviam para suprir suas necessidades energéticas, alimentares, medicinais, resinas, látex e utensílios em geral, para construção de casas, móveis, barcos, veículos como carros de boi, entre outros inúmeros instrumentos, além de sua reprodução cultural e cosmológica.

O pau-brasil (Caesalpinia echinata) foi a primeira espécie florestal intensamente explorada através do extrativismo madeireiro predatório. Nesta época, segundo Meira (2000), cabia aos índios tupinambá à obrigação adentrarem na Mata Atlântica e, trabalharam no corte do pau-brasil, sob as ordens dos portugueses, holandeses, ingleses ou franceses (MEIRA, 2000). Essa espécie florestal, segundo Lorenzi (1998), outrora era explorada para tingir tecidos e fabricar tintas de escrever com uma substância retirada do lenho e denominada "brasileina". Atualmente ainda é aproveitada na construção naval e civil; trabalhos de torno; e confecção de arcos de violinos (LORENZI, 1998).

Após a extração e quase extinção do pau-brasil, as frentes de colonização introduziram o cultivo da cana de açúcar, gramínea de origem asiática, que se tornou o 
produto mais importante da economia brasileira entre os séculos XVI e XVII, sobretudo no nordeste do país. Inicialmente a força de trabalho para produção e beneficiamento da cana de açúcar era indígena, sendo substituída a partir do século XVI pela mão de obra de origem africana. O declínio da produção de cana de açúcar abriu espaço para outra monocultura, a do café, que redistribuiu a mão de obra escrava para as fazendas cafeeiras no sudeste brasileiro. O trabalho e o tráfico de escravos perduraram até o final do século XIX (ALBUQUERQUE, 2006).

O extrativismo não madeireiro da palmeira juçara (Euterpe edulis Martius) se baseou no aproveitamento do palmito que implica no aniquilamento da espécie. Essa espécie é de grande importância para a Floresta Atlântica, devido suas características ecológicas, que produz grande quantidade de frutos e, por isso é considerada como uma espécie-chave, pois seus frutos ficam maduros em uma época de escassez geral de alimentos, quando então são consumidos por um grande número de aves e mamíferos (TERBORGH, 1986; REIS, 1995; GALETTI; ALEIXO, 1998; GALLETI et al. 1999; REIS; KAGEYAMA, 2000).

A palmeira juçara pode fornecer diversos produtos além do palmito: o estipe maduro para caibros e ripas para construção; as folhas são usadas para coberturas temporárias e forrageio; frutos fornecem um "vinho" semelhante ao do açaí Euterpe oleracea Martius (PIO CORRÊA, 1969). Atualmente há o estímulo ao aproveitamento dos frutos da palmeira juçara, fato favorável ao manejo sustentável dessa espécie (REIS et al., 2000),

O emprego de plantas medicinais para a manutenção e a recuperação da saúde tem ocorrido ao longo dos tempos desde as formas mais simples de tratamento local até as formas mais sofisticadas de fabricação industrial de medicamentos (HAMILTON, 2004; LORENZI; MATOS, 2008). Alguns exemplos de plantas medicinais, comumente utilizadas por comunidades tradicionais, povos indígenas e comunidades de quilombo, caiçaras e açorianos, encontradas na Mata Atlântica e ecossistemas associados: a aroeira da praia, pata-de-vaca, unha-de-gato, arnica, anador, sucupira, mutamba, canela, murici, goiaba, caju-roxo e juazeiro.

Outra espécie potencial encontrada nas restingas da Mata Atlântica da Bahia e Sergipe é a mangabeira (Hancornia speciosa), uma árvore que está entre as primeiras espécies frutíferas, cuja ocorrência foi relatada pelos exploradores da costa do Brasil no século XVI (SILVA JUNIOR, 2004). Explorada predominantemente pela ação extrativista, a colheita da mangaba na região litorânea do Estado de Sergipe dá-se nos meses de 
novembro a julho, sendo que a safra de verão abarca de dezembro a abril, e a de inverno, de maio a julho. (MOTA; SILVA JUNIOR; GOMES, 2003).

O licuri (Syagrus coronata) também é conhecido como dicuri, entre outros faz parte da dieta de comunidades tradicionais e moradores da zona rural, se estendendo da zona da mata, próximas às tabuleiros costeiros tomados pela cultura da cana de açúcar e rebanhos bovinos, até a região do sertão. Seu extrativismo também é acompanhado pela produção de bolos e cocadas, e sua comercialização se dá nas feiras livres dos municípios do interior e nas rodovias que cortam os estados da Bahia, Sergipe, Alagoas e Pernambuco (AROUCHA; AROUCHA, 2013).

A aroeira (Schinus terebenthifolius Raddi) ocorre naturalmente em vários estados brasileiros, a partir de Pernambuco e demais estados do Nordeste. Essa espécie da família da Anacardiaceae, chamada popularmente de aroeira vermelha (pimenta rosa), também é encontrada no Rio Grande do Sul e Mato Grosso do Sul. A demanda produtiva dessas indústrias pelo fruto da aroeira, induz a constante procura de novas áreas de ocorrência natural da espécie para a prática extrativista, a exemplo dos municípios do Baixo São Francisco SE/AL. Localidades em que os pescadores artesanais não encontram mais na pesca a garantia de sobrevivência. Nesse caso, recorrem ao extrativismo da aroeira, prática que ocorre desde 2001 entre os pescadores, como forma de complementação da renda familiar (JESUS; GOMES, 2012).

Considerando o aproveitamento dos PFNMs no Brasil, observa-se que para garantir a sobrevivência e a reprodução cultural, comunidades tradicionais, concentram-se na prática do agroextrativismo, imbuindo sua força de trabalho em plantios de subsistência, no aproveitamento de frutos em áreas particulares, reservas extrativistas, territórios tradicionais, constituindo em sistema diversificado de produção, se valendo da exploração do látex de seringueira, castanha do Brasil, babaçu, carnaúba, piaçava, erva mate, açaí entre outros produtos florestais nos diversos Biomas brasileiros em diferentes ecossistemas onde estes produtos ocorrem.

Por volta de 1975 até 1990 , quando foi instituída a primeira reserva extrativista brasileira, grandes mobilizações e embates foram travados contra os fazendeiros, na região de Xapuri, Acre. Esse movimento liderado pelo seringueiro Chico Mendes é um marco referencial no conceito do extrativismo sustentável, onde homem e natureza deixam de se contrapor. A sociedade e as comunidades tradicionais trazem a tona às vantagens do extrativismo dos produtos florestais não madeireiros, conservação dos remanescentes florestais, geração de renda e dignidade aos povos da floresta. A criação das reservas 
extrativistas, isto é, unidades de conservação de uso direto e genuinamente brasileiras, é uma resposta para essa nova demanda. O usufruto dessas áreas extrativistas está condicionado ao manejo sustentável dos recursos naturais.

Em contra ponto autores como Homma (1993) afirmam que à medida que a exploração se intensifica, os recursos vão se esgotando passando a não atender mais a demanda do mercado, de modo que os produtores agroextrativistas são forçados a substituírem esta atividade por outra mais estável e competitiva. Mesmo mantendo a árvore, a matriz para produção futura, o estoque do recurso utilizado está sendo afetado com a exploração, fato que requer medidas para diminuição dos impactos da atividade, como critérios de Boas Praticas de Manejo da espécie florestal explorada.

Para Drummond (1996), o extrativismo - ou uma economia extrativista - é, no sentido mais básico, uma maneira de produzir bens nos quais os recursos naturais úteis são retirados diretamente da sua área de ocorrência natural, em contraste com a agricultura, o pastoreio, o comércio, o artesanato, os serviços ou a indústria. Afirma que o extrativismo na Amazônia é de baixa tecnologia, características das áreas remotas e/ou de fronteiras e, que tem como base bens que são conceitualmente entendidos como renováveis. Argumenta ainda que a exploração de forma extrativista de produtos não madeireiros como a castanha do Pará, o guaraná e a borracha, proporcionou aos extrativistas e comerciantes locais e internacionais uma boa fonte de renda durante o conhecido "ciclo da borracha", mas que durante as últimas décadas observa-se uma tendência de declínio de preços reais de matérias primas. Isso ocorre principalmente porque a agregação de valor, principalmente em termos de mão de obra, tecnologia e marketing é praticamente inexistente dentro das áreas de coleta. Formas de extração de baixa tecnologia se mostram altamente destrutivas.

Prasad et al. (1999) sugere simples intervenções para agregar valor aos PFNMs, como o controle de qualidade na extração do produto, a criação de cooperativas e/ou pequenas empresas familiares para beneficiar e comercializar estes produtos. Quanto maior o controle das etapas de produção por parte dos coletores, maior será sua renda com a atividade extrativista. A verticalização da produção em beneficio das comunidades locais aparece como uma demanda atual para agregação de valor aos produtos gerando mais renda para as comunidades praticantes.

Segundo Emparaire (2000) os estudos sobre extrativismo iniciaram-se nos anos 80 e eram mais relacionados com os seringueiros do acre, os castanheiros da região de Marabá (Pará) ou das populações que exploravam o açaí no estado do Pará. Ainda, segundo o autor, o extrativismo originado nas redes comerciais das potências coloniais ainda está 
presente nas situações mais diversas, continuando a ser elemento estruturador da sociedade amazônica. Afirma também, que o extrativismo é um elemento importante nas estratégias familiares e sua prática depende de vários fatores, como calendário de trabalhos agrícolas, força de trabalho disponível, situação financeira, pressão do comercio local e preferências individuais (saberes tradicionais).

Para Nogueira (2005) em seu estudo sobre pequenos projetos no Bioma Cerrado, o agroextrativismo é parte da tradição produtiva de populações habitantes do meio rural brasileiro, incluindo grupos indígenas, pequenos produtores e grupos remanescentes de quilombos. O agroextrativismo adquiriu grande projeção nos anos 1980 e 1990 a partir da mobilização social amazônica, em defesa das florestas tropicais e de suas populações tradicionais, por meio de lideranças emblemáticas como Chico Mendes. Antes tido como uma forma "primitiva" ou "atrasada" de exploração econômica dos recursos naturais, o agroextrativismo passou então a despontar, no cenário de discussão sobre o desenvolvimento sustentável, como forma de conciliar conservação ambiental e bem-estar humano.

Os PFNMs são vitais para os meios de subsistência rurais nas regiões temperadas e tropicais. Eles proporcionam às comunidades rurais importantes recursos para sua subsistência, tais como remédios, alimentos e abrigo, além de ser uma importante fonte de renda. Os PFNMs também fazem parte de grandes mercados regionais e internacionais, e, durante séculos, produtos como especiarias, plantas medicinais, fragrâncias e resinas estimularam viagens de exploração e sustentaram rotas comerciais em todo mundo (SHANLEY et al., 2005).

O IBGE (2013), na publicação sobre produção da extração vegetal e silvicultura, o termo "extrativismo vegetal" é entendido como o processo de exploração dos recursos vegetais nativos através da coleta ou apanha de produtos como madeiras, látex, sementes, fibras, frutos e raízes, entre outros, de forma racional, permitindo a obtenção de produções sustentadas ao longo do tempo, ou de modo primitivo e itinerante, possibilitando, geralmente apenas uma única produção.

Aprofundar os conhecimentos desses produtos é importante, pois, cerca de $80 \%$ da população de países em desenvolvimento usam os PFNMs para suprir algumas de suas necessidades (MACHADO; 2008). Apesar da grande importância socioeconômica dos PFNMs, constata-se que, geralmente, existe pouca informação sistematizada sobre quantidade, valor, processos de produção (manejo e conservação), industrialização e comercialização desses produtos. Afirma ainda, que tal fato advém da temporalidade e 
variabilidade de sua produção e mercados, sendo que a escassez de informações se constitui como barreira à sua conservação e ao desenvolvimento de estratégias mercadológicas necessárias ao crescimento dessas atividades (FENDER et al. 2008).

\subsubsection{Manejo de Produto Florestal Não Madeireiro}

Manejo florestal é a utilização racional e ambientalmente adequada dos recursos da floresta. É uma atividade econômica oposta ao desmatamento, pois, não há remoção total da floresta e mesmo após o uso, o local manejado manterá sua estrutura florestal. O manejo bem feito segue três princípios fundamentais: deve ser ecologicamente correto, economicamente viável e socialmente justo. O princípio da técnica de exploração de impacto reduzido - principal ferramenta do manejo florestal - é extrair produtos da floresta de maneira que os impactos gerados sejam mínimos, possibilitando a manutenção da estrutura florestal e sua recuperação, por meio do estoque de plantas remanescentes. Diversificar a produção é um dos princípios mais importantes para o uso sustentável dos recursos florestais (SFB, 2014).

O IBGE (2004) conceitua manejo como uma interferência criteriosa do homem no sistema natural, com objetivo de produzir benefícios para o homem, favorecendo o funcionamento essencial desse sistema natural, baseado em método científico com execução do plano experimental.

Do ponto de vista legal, manejo florestal é a administração de práticas de produção, a partir do ecossistema natural ou de agroecossistemas, que visa à obtenção de benefícios econômicos e socioambientais, respeitando-se a sustentabilidade do ecossistema (BRASIL, Decreto $\left.n^{\circ} .1182 / 94\right)$.

Em 2009, foi instituído o Plano Nacional de Promoção das Cadeias dos Produtos da Sociobiodiversidade - Agregação de Valor e Consolidação de Mercados Sustentáveis (Portaria Interministerial MMA/MDA/MDS n ${ }^{\circ}$ 239, de 21 de julho 2009), uma estratégia política para o fortalecimento de cadeias e a consolidação de mercados sustentáveis para produtos da sociobiodiversidade, os quais incluem os produtos não madeireiros da floresta (SFB, 2010).

O Manejo Florestal Comunitário e Familiar é definido legalmente pelo Decreto 6.874, de 5 de junho de 2009, como sendo "a execução de planos de manejo realizada pelos agricultores familiares, assentados da reforma agrária e pelos povos e comunidades tradicionais para obtenção de benefícios econômicos, sociais e ambientais, respeitando-se 
os mecanismos de sustentação do ecossistema". Este decreto institui o Programa Federal de Manejo Florestal Comunitário e Familiar (PMCF), no âmbito dos ministérios do Meio Ambiente e do Desenvolvimento Agrário. O objetivo do PMCF é organizar ações de gestão e fomento ao manejo sustentável em florestas que sejam objeto de utilização pelos agricultores familiares, assentados da reforma agrária e pelos povos e comunidades tradicionais. Atualmente, o programa contempla apenas os biomas Amazônia e Caatinga (SFB, 2010).

As fases do manejo comunitário de PFNMs proposto por Machado (2008) consistem: Fase de Pré Coleta (Organização Social, Potencial Local, Mapeamento dos Indivíduos Produtivos e Licenciamento do Manejo); Fase de Coleta (Critérios e Definições, Procedimentos de Coleta, Equipamentos de Coleta, Estimativas de Produção, Ciclo de Coleta, Controles de Coleta, Medidas Mitigadoras de Impactos); Fase Pós Coleta (Beneficiamento, Transporte, Armazenamento, Monitoramento Participativo do Manejo) e Fase de Comercialização.

O especialista em PFNMs, Alexandre Dias de Souza (comunicação pessoal, 2006) aponta que um bom manejo florestal de espécies não madeireiras passa pela: (a) correta identificação botânica da espécie explorada; (b) descrição do modelo de estabelecimento de parcelas para monitoramento (indicadores para acompanhamento da regeneração, mortalidade e crescimento da espécie); (c) levantamento de dados para saber o número médio de indivíduos reprodutivos por hectare e produção média por indivíduo; (d) o volume médio potencial por hectare; (e) descrição detalhada da extração ou coleta; (f) apontamentos quanto ao cronograma de exploração; (g) diagnóstico das operações de prébeneficiamento e beneficiamento dos produtos em nível de comunidades extrativistas; (h) estabelecimento de medidas mitigadoras da flora e fauna local; e (i) definição do tempo estimado para regeneração e (j) recomposição do volume de matéria prima extraído (comunicação pessoal). Segundo Alexandre Dias de Souza, o desenvolvimento de Guias de Manejo para as espécies e/ou para grupos de produtos, como por exemplo, alimentícios, medicinal, exsudatos, óleos vegetais, óleos essenciais, frutos, cascas, palmitos, folhas e raízes, contribui com diretrizes para os extrativistas e entidades que apoiam o desenvolvimento sustentável local. Esse especialista considera ainda para o manejo de espécies e/ou grupos o exame das seguintes etapas:

1. Fase Pré - Exploratória: Mapeamento e Marcação dos Indivíduos; Estimativa de Produção; Plano de Monitoramento; e Medidas para Reduzir Impactos. 
2. Fase Exploratória: Época (safra e/ou inverno/verão); Métodos de Coleta; Medidas para Prevenir e Reduzir Impactos.

3. Fase Pós-Exploratória: Monitoramento; Procedimentos de Medição dos Indicadores, Transporte, Armazenamento e Pré-beneficiamento.

De forma mais generalista, Soares; Silva (2008) consideram necessários três caminhos para fomentar a adoção de procedimentos de extração de PFNMs: a) redução da burocracia na implantação de processos de produção de um dado PFNM; b) apoiar o fortalecimento das comunidades extrativistas a partir da regularização fundiária de suas áreas de coleta; c) garantia de fomentos que apoiem a gestão técnica e financeira dos projetos comunitários (ATER e comercialização) com combate à informalidade predatória, ou seja, aumento na transparência dos processos produtivos e punir de maneira eficiente os infratores.

Peters (1994) apresenta as seguintes etapas necessárias para se realizar o manejo de um PFNM: (a) seleção da espécie; (b) quantificação; (c) estudos de produção; (d) avaliação periódica da regeneração; (e) avaliação periódica da extração; e (f) ajustes na extração

Segundo Machado (2008), o manejo de produtos florestais não madeireiros (neoextrativismo ou extrativismo sustentável) merece atenção especial, pois, se conduzido de forma racional, além de tornar as florestas rentáveis, mantém, em muitos casos, a estrutura e biodiversidade praticamente inalteradas. Segundo esse autor, os inventários florestais são utilizados como principal mecanismo de avaliação do potencial de aproveitamento dos recursos genéticos vegetais, fornecendo importantes informações sobre a estrutura da floresta. $\mathrm{O}$ autor acrescenta ainda que, para o levantamento do potencial produtivo local é também necessário o levantamento etnobotânico, mapa mental, os inventários amostrais e os levantamentos de estrutura da população. O mapa mental ${ }^{5}$ dará bons indicativos de áreas de ocorrência das espécies, bem como a distribuição da população: aleatória ou agregada, o que facilitará a escolha do método de amostragem do inventário florestal.

Machado (2008) sugere a realização do mapeamento dos indivíduos produtivos através de cinco métodos: elaboração de croquis da área; mapeamento com imagens de satélite; definição do perímetro da área; método da bússola e passos calibrados; método do GPS (sistema de posição global).

\footnotetext{
${ }^{5}$ Mapa mental consiste no desenho (croqui) de uma determinada área, feito de forma coletiva, aonde cada participante vai contribuindo com informações da área a ser manejada (desenhada). Metodologia participativa de baixo custo, adotada em diagnósticos rápidos, que tem a finalidade de apresentar o uso do solo naquele momento e na perspectiva dos moradores.
} 
No entendimento do professor Dr. Manoel Claudio Silva Júnior, em comunicação pessoal (2011), afirmou que um bom manejo de produtos florestais não madeireiros, só será viável quando as comunidades entenderem a importância da reposição, através do plantio da espécie explorada, seja por meio de enriquecimento de seus quintais, aldeias, sistemas agroflorestais, enriquecimento de capoeiras ou plantios comerciais. Recomenda ainda, que na falta de informações técnicas e científicas, quando o PFNM tiver origem na exploração de frutos, os agroextrativistas devem deixar de $10 \%$ a $30 \%$ dos frutos para reposição florestal e alimentação da fauna silvestre.

\subsubsection{Comunidades Tradicionais}

O extrativismo da piaçava no Estado da Bahia tem intensa relação com o histórico de ocupação dos povos indígenas e a chegada dos negros de origem Africana na Bahia. Segundo Sampaio (2011) o século XVI foi marcado pelo contato entre o colonizador e as diversas tribos tupí que dominavam o litoral nordestino, no século seguinte, quando esses se encontravam já quase que completamente dizimados pelas epidemias e guerras havidas principalmente no governo de Mem de Sá (1557-1572) e com a maior parte da sua população sobrevivente nas capitanias da Bahia, Ilhéus e Pernambuco escravizada ou reduzida em aldeias missionárias em rápido declínio, foi à vez dos índios do Sertão. (HEMMING, 1978; LEITE, 1945 apud SAMPAIO, 2011).

A penetração nessa vasta área foi feita de início principalmente a partir da Baía de Todos os Santos e através de numerosas boiadas conduzidas pelos grandes sesmeiros, dentre os quais se destacaram, pelo seu poder, os d'Ávila, senhores da Casa da Torre (SAMPAIO, 2011).

Já os primeiros contingentes de negros de negros foram introduzidos no Brasil nos últimos anos da primeira metade do século XVI, talvez em 1538. Eram pouco numerosos, porém, como se deduz pelas dificuldades que têm os historiados em documentar esses primeiros ingressos. Logo a seguir, entretanto, com o desenvolvimento da economia açucareira, passam a chegar em grandes levas. A caçada de negros na África, sua travessia e a venda aqui passam a constituir o grande negócio dos europeus, em que imensos capitais foram investidos e que absorveria no futuro, pelo menos metade do valor do açúcar e, depois, do ouro (RIBEIRO, 1995).

Voltando as comunidades indígenas, logo após a expulsão dos holandeses do Brasil, nos meados do século XVII, as populações indígenas do litoral, predominantemente 
de etnolinguística tupi, passaram a ser perseguidas e consideradas aos poucos como sendo não mais formadas exclusivamente de "índios". Surgindo então a expressão "cablocos", adaptação do termo tupi para denominar os "retirados da mata". Esta tendência foi ainda mais intensificada com a expulsão das missões jesuítas do Brasil, no início da segunda metade do século XVIII, seguida do enfraquecimento e expulsão de outras ordens religiosas (LARANJEIRAS, 2011).

Paralelamente a indústria canavieira encontrava resistência efetiva e enfrentou a oposição ativa por parte do negro escravo, que lutou por sua liberdade não apenas contra o amo, mas contra toda a sociedade colonial, unida e coerente na defesa do sistema. Foi uma luta longa e terrível que se exprimiu de mil modos. Diariamente, pela resistência dentro do engenho, cujo funcionamento exigiu o pulso e o açoite do feitor para impor e manter o ritmo de trabalho. Episodicamente, pela fuga de negros já conhecedores da terra para territórios ermos onde se acoitavam, formando quilombos. (RIBEIRO, 1995).

Na região do baixo sul baiano destacavam-se os seguintes 'mocambos': Jaguaripe (1667 e 1706), Camamu (1692), Cairu (1699 e 1722), Barra do Rio das Contas (1736) e Ilhéus (1789 e 1807), todos no território da antiga Capitania de Ilhéus (SCHWARTZ, 2001).

A região do Baixo Sul da Bahia foi uma das primeiras regiões brasileiras a sofrer os efeitos da colonização portuguesa no Brasil, sendo colonizada ainda na primeira metade do século XVI. A ocupação iniciou no arquipélago de Tinharé, onde por volta de 1535 foi fundada uma vila, mais tarde foi transferida para Vila de São Jorge de Ilhéus, hoje cidade de Ilhéus. Nos séculos XVI e XVIII essa região era considerada um dos principais polos produtores de madeiras nobres, produção extrativista, pesca e produção de farinha.

Esses locais são os remanescentes das comunidades quilombolas e, conforme o Decreto $n^{\circ} 4.887 / 03$ art. 2, consideram-se remanescentes das comunidades quilombolas os grupos étnico-raciais, segundo critérios de auto-atribuição, com trajetória histórica própria, dotados de relações territoriais específicas, com presunção de ancestralidade negra relacionada com a resistência à opressão histórica sofrida.

Conforme esse decreto que define o que são as comunidades quilombolas, considerando também a Constituição Federal de 1988, art. 231 e art. 68 do Ato das Disposições Constitucionais Transitórias, onde define que os territórios tradicionais são os espaços necessários à reprodução cultural, social e econômica dos povos e comunidades tradicionais, sejam eles utilizados de forma permanente ou temporária. 
Os negros do Baixo Sul baiano ${ }^{6}$, através de sua luta diária pelos territórios, conseguiram certificar mais de 40 comunidades quilombolas junto à Fundação Cultural Palmares, essas comunidades estão pontuadas na Tabela 01 (FUNDAÇÃO PALMARES, 2014). Grande parte dessas comunidades quilombolas ainda vive dos cultivos de subsistência, extrativismo da piaçava, pesca e da introdução de cultivos exóticos, como o cravo da índia, seringueira, cacau e pupunha, em áreas de predominância de vegetação da Mata Atlântica.

Tabela 01: Comunidades quilombolas certificadas pela Fundação Palmares no Baixo Sul Baiano.

\begin{tabular}{|c|c|c|c|c|}
\hline Cidade & Código IBGE & Comunidade & Data/Publicação & Total \\
\hline \multirow{6}{*}{ Ituberá } & \multirow{6}{*}{2917300} & Brejo Grande & $07 / 06 / 2006$ & \multirow{6}{*}{06} \\
\hline & & Cágados & $13 / 03 / 2007$ & \\
\hline & & Curral Da Pedra & $07 / 06 / 2006$ & \\
\hline & & Ingazeira & $08 / 06 / 2005$ & \\
\hline & & Lagoa Santa & $08 / 06 / 2005$ & \\
\hline & & São João de Santa Bárbara & $12 / 05 / 2006$ & \\
\hline \multirow{10}{*}{ Camamu } & \multirow{10}{*}{2905800} & Acaraí & $05 / 03 / 2008$ & \multirow{10}{*}{10} \\
\hline & & Barroso & $05 / 03 / 2008$ & \\
\hline & & Garcia & $05 / 03 / 2008$ & \\
\hline & & Getimana & $05 / 03 / 2008$ & \\
\hline & & Pedra Rasa & $05 / 03 / 2008$ & \\
\hline & & Pimenteira & $10 / 04 / 2008$ & \\
\hline & & Porto Do Campo & $05 / 03 / 2008$ & \\
\hline & & Pratigi & $05 / 03 / 2008$ & \\
\hline & & Ronco & $05 / 03 / 2008$ & \\
\hline & & Tapuia & $05 / 03 / 2008$ & \\
\hline \multirow[t]{2}{*}{ Igrapiúna } & \multirow[t]{2}{*}{2913457} & Laranjeiras & $12 / 05 / 2006$ & \multirow[t]{2}{*}{02} \\
\hline & & Sapucaia & $17 / 06 / 2011$ & \\
\hline \multirow{2}{*}{$\begin{array}{c}\text { Presidente } \\
\text { Tancredo } \\
\end{array}$} & \multirow{2}{*}{2925758} & Alto Alegre & $05 / 03 / 2008$ & \multirow[b]{2}{*}{02} \\
\hline & & Pau da Letra & $05 / 03 / 2008$ & \\
\hline \multirow{5}{*}{$\begin{array}{l}\text { Wenceslau } \\
\text { Guimarães }\end{array}$} & \multirow{5}{*}{2933505} & Jericó & $04 / 11 / 2010$ & \multirow{5}{*}{05} \\
\hline & & Mucugê & $11 / 05 / 2011$ & \\
\hline & & Nova Esperança & $09 / 12 / 2008$ & \\
\hline & & Rio Preto & $06 / 07 / 2010$ & \\
\hline & & Sarilândia & $04 / 11 / 2010$ & \\
\hline \multirow{2}{*}{ Nilo Peçanha } & \multirow{2}{*}{2922607} & Boitaraca & $19 / 04 / 2005$ & \multirow{2}{*}{02} \\
\hline & & Jatimane & $19 / 04 / 2005$ & \\
\hline Teolândia & 2931202 & Boqueirão & $01 / 12 / 2011$ & 01 \\
\hline \multirow{4}{*}{ Taperoá } & \multirow{4}{*}{2931202} & Graciosa & $05 / 03 / 2008$ & \multirow{4}{*}{04} \\
\hline & & Lanmego & $05 / 03 / 2008$ & \\
\hline & & Miguel Chico & $05 / 03 / 2008$ & \\
\hline & & Pedra Branca do Riacho do Ouro & $24 / 05 / 2013$ & \\
\hline \multirow{6}{*}{ Cairu } & \multirow{6}{*}{2905404} & Batateira & $06 / 07 / 2010$ & \multirow{6}{*}{07} \\
\hline & & Filhos e Amigos de Cairu & $07 / 02 / 2007$ & \\
\hline & & Galeão & $13 / 03 / 2007$ & \\
\hline & & Torrinhas & $13 / 12 / 2006$ & \\
\hline & & Vila Monte Alegre & $12 / 05 / 2006$ & \\
\hline & & Prata & $07 / 02 / 2007$ & \\
\hline
\end{tabular}

\footnotetext{
${ }^{6}$ Microrregião com 11 municípios: Nilo Peçanha, Igrapiúna, Ituberá, Maraú, Piraí do Norte, Taperoá,
} Camamu, Presidente Tancredo Neves, Cairu, Valença e Ibirapitanga. 


\begin{tabular}{|c|c|c|c|c|}
\hline & & Cajazeiras & $07 / 02 / 2007$ & \\
\hline \multirow{8}{*}{ Valença } & \multirow{7}{*}{2932903} & Arueira & $05 / 05 / 2009$ & \multirow{7}{*}{07} \\
\hline & & Buraco Azul & $05 / 05 / 2009$ & \\
\hline & & Jaqueira & $05 / 05 / 2009$ & \\
\hline & & Novo Horizonte I & $05 / 03 / 2008$ & \\
\hline & & Sapé Grande & $05 / 05 / 2009$ & \\
\hline & & Sarapuí & $05 / 03 / 2008$ & \\
\hline & & Vila Velha do Jequiriçá & $05 / 05 / 2009$ & \\
\hline & & & TOTAL & 46 \\
\hline
\end{tabular}

O Decreto $\mathrm{n}^{\circ}$ 6.040/07 define como Povos e Comunidades Tradicionais àqueles grupos culturalmente diferenciados e que se reconhecem como tais, que possuem formas próprias de organização social, que ocupam e usam territórios e recursos naturais como condição para sua reprodução cultural, social, religiosa, ancestral e econômica, utilizando conhecimentos, inovações e práticas gerados e transmitidos pela tradição (BRASIL, 2007). A região do Baixo Sul baiano está concentrada de comunidades quilombolas, alguns povos indígenas, convivendo com os pescadores artesanais, marisqueiros, catadores de caranguejo, posseiros e outros grupos formados por agricultores e agricultoras familiares. A Figura 01 apresenta o mapa de ocorrência da piaçava e as respectivas terras indígenas (T.I.) e quilombos demarcados existentes nessa área.

$\mathrm{Na}$ perspectiva de cidadania e busca de direitos, às comunidades negras buscam através do trabalho manual e de beneficiamento dos recursos naturais existentes na região, o que já no século XIX era propagado por Manoel Quirino ${ }^{7}$, a de que o trabalho, além de se constituir em esforço produtivo que enriqueceu os senhores e construiu a nação, também se caracterizou em ação que conduziu à liberdade muitos escravos e a outras conquistas sócio-políticas de seus descendentes pela manifestação da criatividade, da competência, do talento, das lutas pelos direitos civis e políticos. Foi com este sentimento que produziu a sua obra, ressaltando o valor da arte, do trabalho, de artistas e operários nas suas variadas expressões (LEAL, 2006).

O quilombola pesquisador, Egnaldo da Silva, mestre em história pela PUC SP, em 2013 fez um resgate histórico (1950 a 2011) do processo de ocupação da comunidade Remanescente Quilombola de Lagoa Santa (SILVA, 2013), vizinha ao Quilombo do Brejo Grande (Figura 02) no Município de Ituberá. Segundo Egnaldo, a região começou a ser

\footnotetext{
${ }^{7}$ Brasileiro afro-descendente, nascido em Santo Amaro da Purificação no recôncavo baiano a 28 de julho de 1851, órfão desde os 4 anos de idade, Manoel Raymundo Quirino viveu intensamente acontecimentos significativos da história do Brasil, e da Bahia em particular, que marcaram os anos finais do Império e iniciais da República.
} 
ocupada entre o final do século XIX e início do XX, através de posse ${ }^{8}$ terras, compra de terras e de heranças que foram passadas para as gerações futuras.

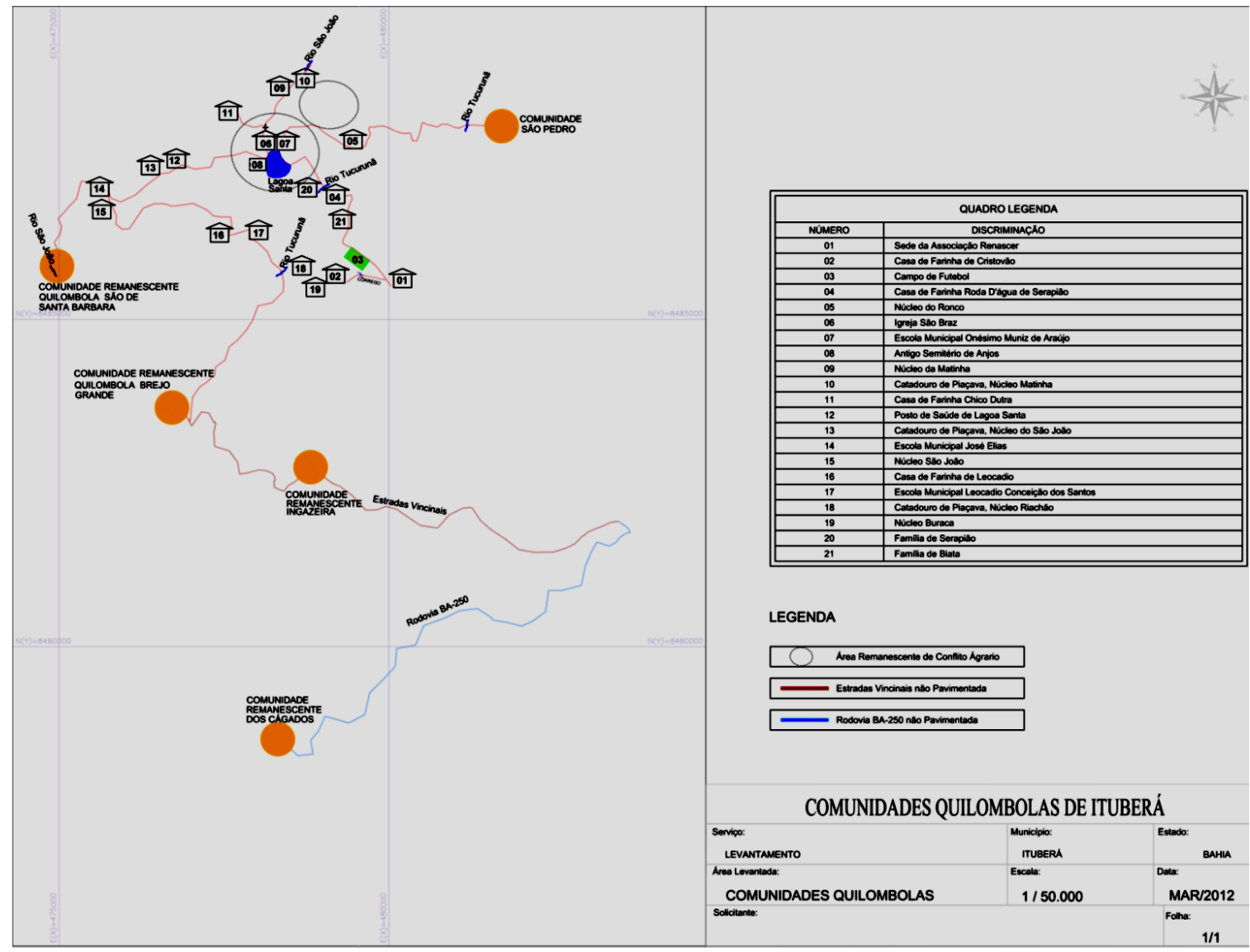

Figura 02: Mapa das comunidades quilombolas do município de Ituberá, AQBGI é terceira de baixo para cima do mapa. Fonte: Teixeira apud Silva (2013).

Os antepassados buscavam na região a possibilidade de desenvolver ensaios de cidadania, que passou a ser ameaçado a partir do século XX, devido à valorização da terra e introdução de novas culturas na região, tais como seringueira (Hevea brasiliensis), guaraná (Paullinia cupana) e cravo da índia (Syzygium aromaticum); além da expansão das fazendas de cacau (Theobroma cacao), que demandavam o aumento da fronteira agrícola, com a exploração de novas áreas. Neste aspecto, a historiografia oferece destaque à figura dos coronéis do cacau, vistos como desbravadores e responsáveis pela ascensão econômica da região (SACRAMENTO, 2008).

Entre os municípios de Ituberá e Igrapiúna, a Firestone instalou-se na região, ocupando uma área de aproximadamente dez mil hectares, desenvolvendo o monocultivo da seringueira para extração de látex. Desde então a seringueira passou a ser cultivada em

\footnotetext{
${ }^{8}$ A categoria de posseiro é entendida como aquele que adquire (ou ocupa) e faz uso de uma determinada área de terra sem ter título de propriedade expedido, em seu nome, pelo Estado ou pela União (MYSKIW, 2002).
} 
larga escala por fazendeiros e agricultores familiares da região, com apoio e incentivo das empresas de fomento e extensão rural (SILVA, 2013).

O Índice de Desenvolvimento Humano (IDH) do Baixo Sul Baiano é baixo, mas vem crescendo, esta microrregião compreende 11 municípios que, juntos, possuem cerca de 300 mil habitantes. Nesta região existe um mosaico de cinco Áreas de Proteção Ambiental (APA) de Pratigi, Guaibim, Boa Esperança, Tinharé/ Boipeba e Baía de Camamu, sendo considerado o maior espaço de Mata Atlântica remanescente do estado da Bahia.

O IDH de Ituberá, por exemplo, foi de 0,418 em 2000 e passou para 0,606 em 2010, índice considerado médio. A população de Ituberá passou de 24.923 habitantes, em 2000 para 26.591 habitantes em 2010. A população em extrema pobreza vem diminuindo, $56,23 \%$ (1991), 32,11\% (2000) e 11,44\% (2010). A população jovem do município passou de 14.514 (58,24\%) em 2000 para 17.156 (64,52\%) jovens em 2010 (PNUD, 2013).

No Município de Nilo Peçanha estão localizados dois quilombos, Boitaraca e Jatimane, Áreas de Proteção Ambiental (APA) de Pratigi, bem como a sede da Cooperativa de Produtores e Produtoras de Piaçava do Baixo Sul da Bahia (COOPRAP), Casa Familiar Agroflorestal (CFAF) e Instituto de Desenvolvimento Sustentável do Baixo Sul da Bahia (IDES), parceiras da Fundação Odebrecht. Neste município o IDH cresceu 42,45\%, mas continua sendo considerado baixo. Em 2001 o índice foi de 0,384 e em 2010 passou para 0,547. A população passou de 11.213 em 2001 para 12.530 habitantes em 2010 (PNUD, 2013). Nilo Peçanha tem aproximadamente $30 \%$ do seu PIB oriundo do extrativismo da fibra da piaçava (Attalea funifera), sendo está à maior proporção entre os municípios do APL da piaçava no Sul Baiano. O povoado do Quilombo de Boitaraca está localizado a 20 km do Município de Nilo Peçanha, possui uma área de 621ha, com ecossistemas associados à Mata Atlântica, locais de ocorrência natural da piaçava e pesca artesanal. A comunidade é formada atualmente por 40 casas totalizando 71 habitantes, que vivem da agricultura de subsistência, da pesca artesanal e principalmente da extração da piaçava (bruta e pré-beneficiada), sendo essa a sua principal atividade produtiva e fonte de renda.

O IDH do Município de Canavieiras também é considerado baixo. Em 2001 era de 0,439 e em 2010 passou para 0,590. A população vem diminuindo. Em 2001 era de 34.641 habitantes e em 2010 passou para 32.336 habitantes (PNUD, 2013). Nessa região predominam plantios de piaçava, pertencentes a médios e grandes produtores de piaçava. Esses produtores cedem suas áreas para os extrativistas de piaçava, que, inicialmente, 
extraem as fibras e pré beneficiam, e, posteriormente, vendem as fibras limpas e, dividem os ganhos ao meio. Por isso, tais extrativistas são conhecidos como 'meeiros'.

\subsection{4 - Piaçava (Attalea funifera Martius) da Bahia}

Existem pelo menos três espécies diferentes de piaçaveiras e que são exploradas comercialmente no Brasil, desde o período colonial: a piaçava do Pará (Leopoldinia piassaba), originária do Amazonas e do norte do Pará; a piaçava acreana (Aphandra natalia), que ocorre no vale do Rio Juruá e, piaçava da Bahia (Attalea funifera) (LORENZI, 2010).

A piaçava é uma palmeira que pertence à família Arecaceae e está associada a solos arenosos, leves e profundos (podzólicos) e também solos sílico-arenosos (BONDAR; 1942a). Segundo Sá et al. (1982) o clima da faixa litorânea da Bahia é do tipo Af, clima quente e úmido, sem estação seca definida, temperatura anual de $24^{\circ} \mathrm{C}$, umidade do ar em torno de $80 \%$ e boa luminosidade (cerca de 2.500 horas de luz/ano). As chuvas caem com regularidade durante todo o ano, variando de $1.600 \mathrm{~mm}$ ao sul de Canavieiras até Prado (limite sul da espécie), a mais de $2.000 \mathrm{~mm}$ anuais, de Ilhéus à Valença, área de maior concentração da espécie (GUIMARAES; SILVA, 2012).

A piaçava da Bahia, também conhecida como piaçava, piaçaba, piaçava da Bahia e coqueiro de piaçava, é uma palmeira genuinamente da flora brasileira. Piaçava significa "planta fibrosa" na língua Tupi, com a qual se faz utensílios caseiros. Foi descrita por Martius, em 1825, utilizando a união de duas palavras latinas: "funis", substantivo que significa "corda", "amarra", e "ferens", adjetivo que significa "que produz". São conhecidos 22 espécies de palmeiras deste gênero, sendo a mais importante Attalea funifera. Cresce espontaneamente e é explorada economicamente desde o período do Brasil colonial (VINHA; SILVA, 1998).

A piaçava da Bahia é uma palmeira solitária, sem espinhos e ereta. No sul do estado se caracteriza por ser caulescente e no norte é praticamente acaule. A altura média da planta varia entre 8 a 15 m e o diâmetro está em torno de 20 a $25 \mathrm{~cm}$. A planta apresenta oito a dez folhas, com arranjo espiralado, disposição quase vertical, retas e com ápices ligeiramente arcados, com aproximadamente $9 \mathrm{~m}$ de comprimento total. As margens do pecíolo apresentam fibras rígidas (piaçava) de até 3,5 m de comprimento (SILVA, 2002).

Por ser uma espécie pioneira, a sua produtividade aumenta à medida que a competição por luz diminui. Na Bahia é comum encontrar a palmeira em áreas de 
pastagens (Figura 03) como um consórcio bem sucedido. Também estão relacionadas com o plantio do cacau (GAMA et al., 2009).

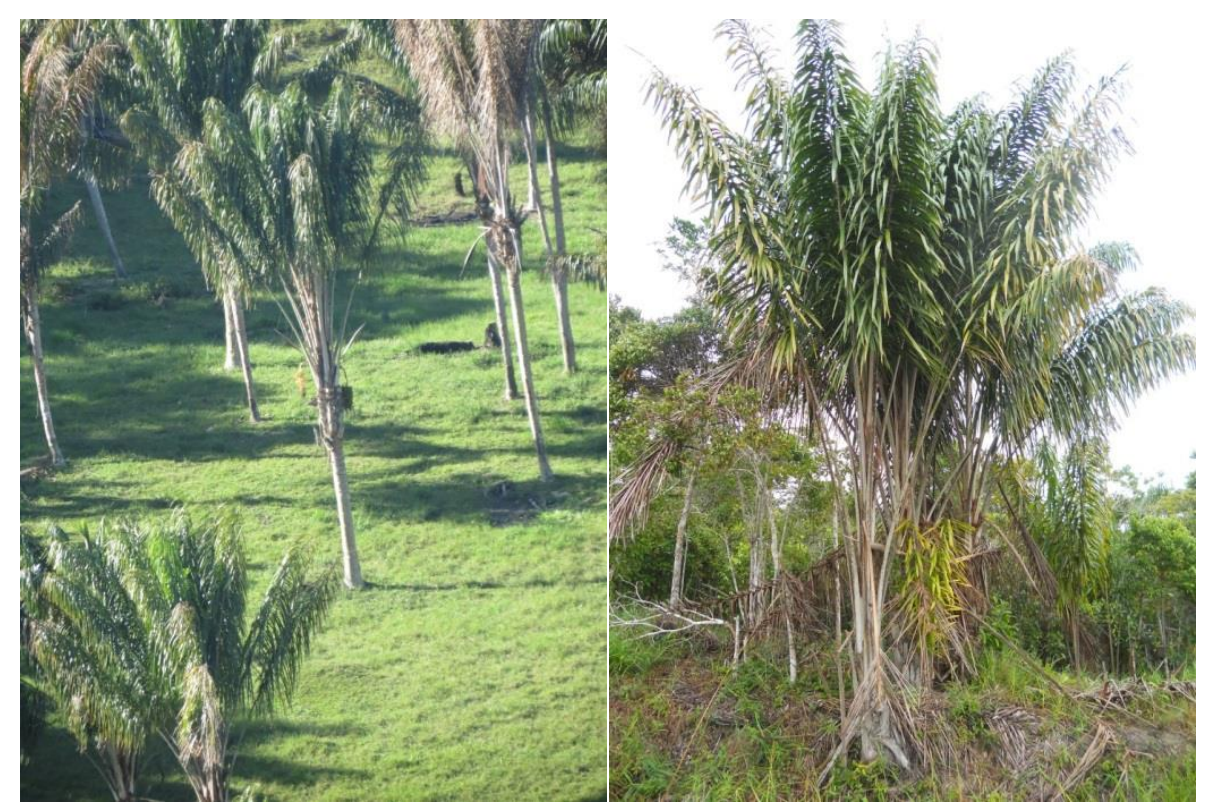

(a)

(b)

Figura 03: Palmeira de piaçava no pasto aberto (a) e capoeira em regeneração (b).

De acordo com Voeks (1988), a piaçava é uma planta monóica, produtora de inflorescências masculinas e femininas. No entanto, segundo esse autor, quando ocorre em florestas densas, onde a competição por raios solares é grande, a produção de inflorescências diminui e a planta passa a produzir apenas inflorescências masculinas. Quando a copa da palmeira atingir o dossel superior da floresta, onde há maior disponibilidade de energia, a planta retorna a produção de inflorescências femininas, o que, consequentemente, possibilita a produção de frutos.

A polinização das flores é feita principalmente por insetos como abelhas, gorgulhos, mosquitos e pequenos besouros. Cada inflorescência desenvolve-se na axila da folha e é protegida por uma espata ${ }^{9}$ que se dividi longitudinalmente ao longo da superfície ventral e que se abre após o terceiro mês do seu aparecimento (Figura 04). Apresentam três tipos de inflorescência: andrógina, estimada e estéril. A produção de inflorescência varia de quatro a sete por ano e por planta. A inflorescência possui fragrância característica e

9 A espata em palmeiras é mais comumente chamada de bráctea peduncular, é lenhosa, profundamente sulcada ou raiada, com cobertura que vai do bege claro, passando a castanho e finalmente a cinza-escuro (GUIMARAES; SILVA, 2012). Essa parte da planta também é utilizada para fazer artesanatos, também denominada de 'busa'. 
forte. As flores são brancas com a espata ainda fechada, passando de branco-marfim para amarelo-claro até se tornarem castanhas quando fecundadas (VOEKS, 1988; GUIMARAES; SILVA, 2012). Esses autores afirmam que a floração pode ocorrer o ano todo com maior frequência no verão, ou seja, de dezembro a abril.

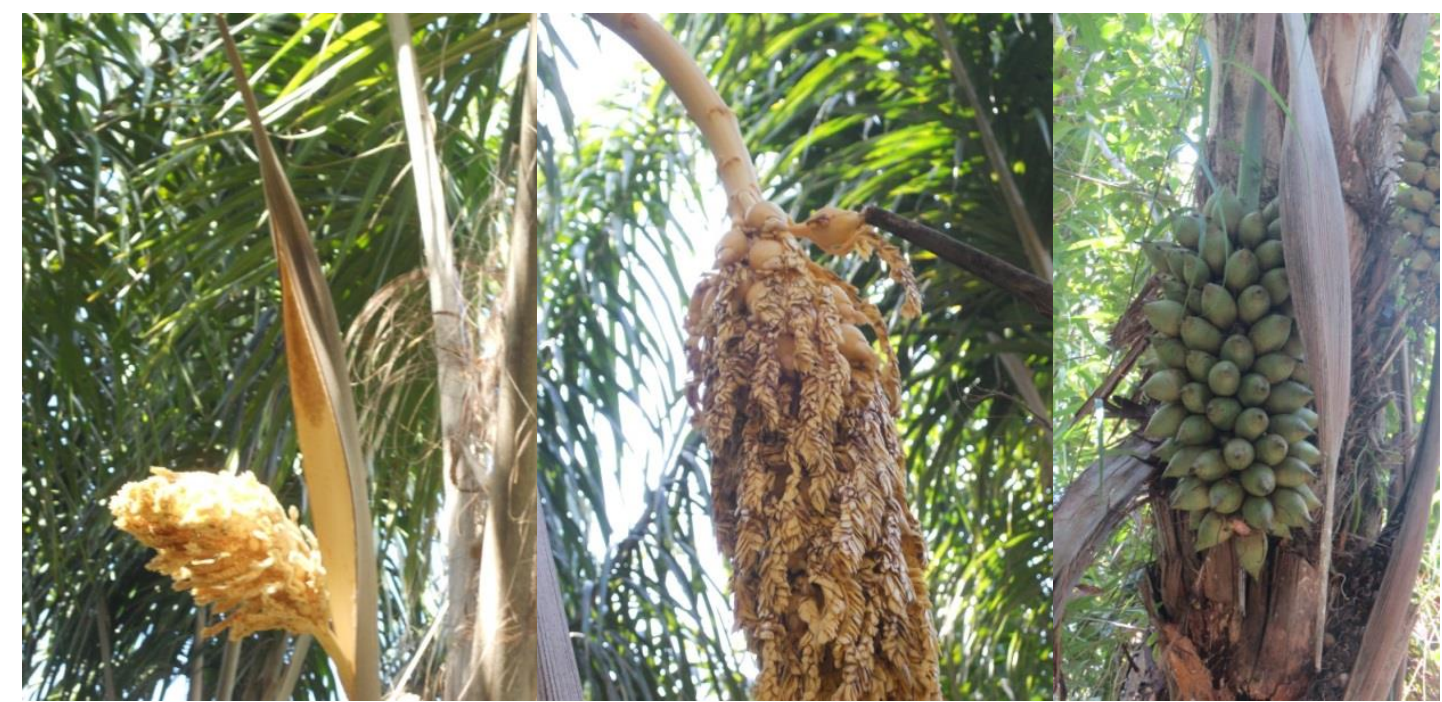

(a)

(b)

(c)

Figura 04: (a) Espata (busa), (b) inflorescência e (c) cachos de frutos da piaçava da Bahia.

As primeiras flores aparecem quando as plantas têm aproximadamente entre 8 a 10 anos de idade e esta fase é denominada o período de "coqueiro" da piaçava. As flores fecundadas produzem frutos por cerca de um ano, ficando eles reunidos em cachos (SILVA, 2002).

O pico da floração e queda dos frutos (Figura 04) é no verão, ou seja, de dezembro a abril é possível encontrar flores e frutos maduros caídos (NOBLICK, 1991). O autor ressalta que a floração, frutificação, amadurecimento e queda ocorrem durante todo o ano, mas eleva-se no verão.

O fruto da piaçava tem forma de elíptica e mede de 10 a $15 \mathrm{~cm}$ de comprimento por 5,5 a 9,0 cm de diâmetro (Figura 05), é formado pelo epicarpo (camada externa com 2 a 2,5 $\mathrm{mm}$ de espessura), mesocarpo (camada intermediária de 3 a $6 \mathrm{~mm}$ de espessura) conhecido tradicionalmente como 'satim', e o endocarpo (camada interna, óssea com espessura entre 1,5 a 2,0 cm) que fica em contato com as sementes (MARTIUS, 1878; NOBLICK, 1991; apud GUIMARAES; SILVA, 2012). Cada fruto pesa em média entre 200 a 270 gramas (VINHA; SILVA, 1998). Melo et al. (2000) apontam que o peso médio das sementes foi de 110 gramas (Figura 05). Também verificaram que a massa média de 33 cachos de frutos foi de $21 \mathrm{~kg}$, contendo 190 frutos por cacho. Contudo, Guimarães e Silva 
(2012) encontraram cachos com $111 \mathrm{~kg}$, bem superiores que os de $70 \mathrm{~kg}$ citados por Bondar (1942a).

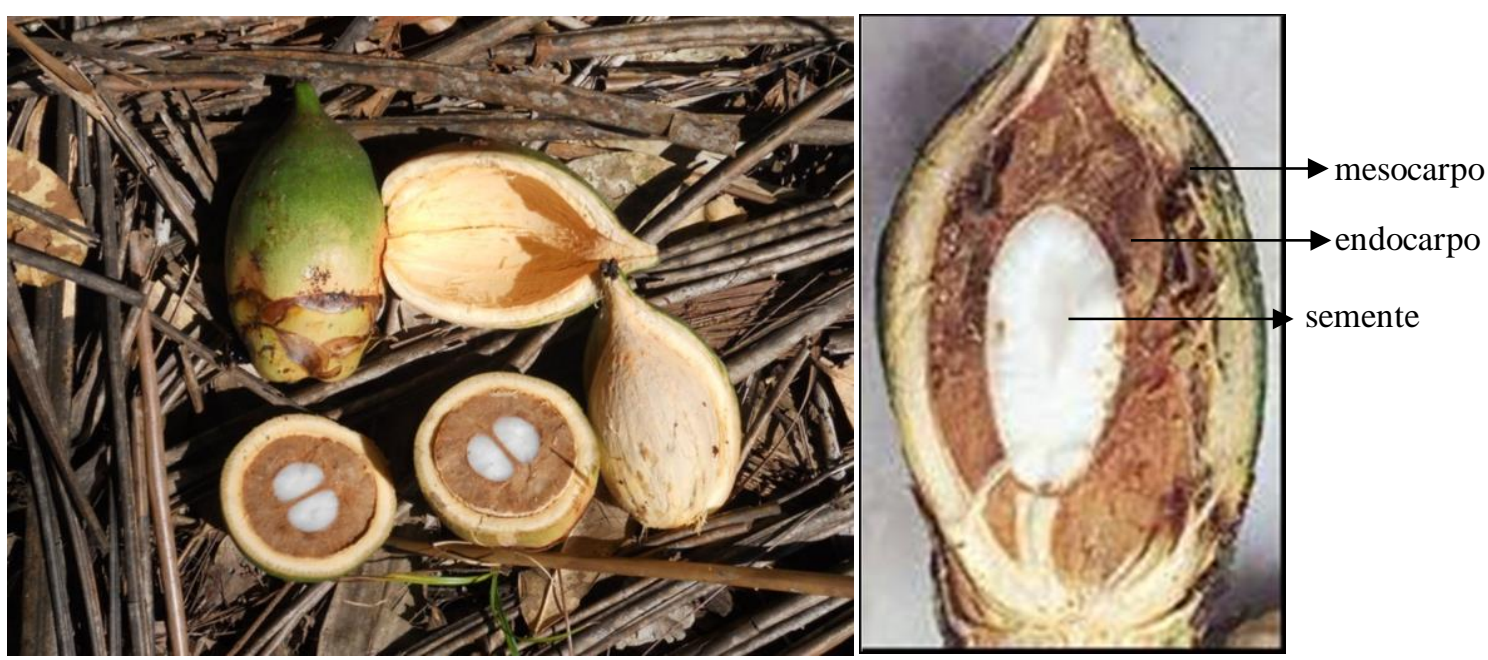

Figura 05: Fruto da piaçava: tamanho, aspectos externos e internos.

Os principais dispersores naturais dos frutos é a paca (Cuniculus sp.) e a cotia (Dasyprocta spp.), consomem o mesocarpo enterram os frutos, longe das plantas mães, ajudando na dispersão da espécie. Atualmente a dispersão natural da espécie está bastante comprometida devido à diminuição dos fragmentos florestais e consequentemente diminuição da fauna (SILVA, 2002). O autor ressalta que os roedores que auxiliam no processo de dispersão das sementes da piaçava estão ficando raros nas matas de piaçava e o ataque aos frutos maduros é constante, são causados por bruquídeos (besouro do coco), da família Bruchidae que destroem as sementes. Portanto, segundo Silva (2002), a dispersão natural da piaçava está ficando praticamente impossível e só pode ocorrer com a intervenção do homem.

Vinha; Silva (1992) realizaram experimentos com semeadura direta em campo e concluíram que a melhor germinação foi em uma área em estágio avançado de recuperação, resultando em $67 \%$ de emergência das plântulas, após um ano, devido a maior umidade do solo. Na área com plantio antes da queima obteve $30 \%$ de germinação, indicando que o fogo tem pouco ou nenhum efeito na superação da dormência das sementes. Nas áreas abertas o inicio da protusão do eixo embrionário foi no quinto mês da semeadura e prolongou-se até o 18 meses seguintes, atingindo $36,7 \%$ de germinação no final da avaliação. 
Melo (2000) testou vários tratamentos nos frutos de piaçava para acelerar a germinação, o resultado mais promissor foi a padronização da amostra quanto ao teor de umidade dos frutos, antes do processo germinativo. Também constatou o aumento da velocidade e da porcentagem de germinação com a utilização da temperatura de $30 \mathrm{C}^{\circ}$.

Guimarães; Silva (2012) recomendam a utilização das seguintes técnicas para acelerar a germinação: uso de frutos frescos (recém maduros); retirada do epicarpo e mesocarpo de cada fruto; descanso de 72 horas em água limpa (com trocas diárias); acomodar os frutos de modo que as partes mais fina fique para cima. Assim, afirmam os autores, a primeira folha será emitida após 120 dias.

O desenvolvimento da piaçava tem grande influência na qualidade e na quantidade da fibra produzida pela planta. Portanto, é importante conhecer as diferentes fases do desenvolvimento da palmeira, bem como as terminologias tradicionais adotadas para definir cada fase de desenvolvimento.

De acordo com um estudo realizado pela empresa Veracel Celulose S/A, no Município de Santa Cruz de Cabrália/ BA, comunidade Ponto Central, em área de ocorrência natural da espécie (BERGAMO; RODRIGUES, 2007), as fases de desenvolvimento da piaçava são: Patioba, Bananeira, Coqueiro recém formado e Coqueiro. A fase patioba é a fase de plântula e muda, em que os indivíduos têm até 4 anos de idade e as fibras produzidas pelas plantas não devem ser retiradas para o uso, pois, são finas e pouco resistentes. As três fases subsequentes já estão relacionadas com produção de fibra de piaçava.

Gama et al. (2009) também realizaram um estudo em área de ocorrência natural da piaçava, localizada na Reserva Indígena Pataxó da Jaqueira, Município de Porto Seguro/BA. Os autores subdividiram o desenvolvimento da piaçava nos seguintes estágios: $\underline{\text { Patioba (indivíduo jovem); Bananeira Nova; Bananeira em Produção; } \text { Coqueiro em }}$

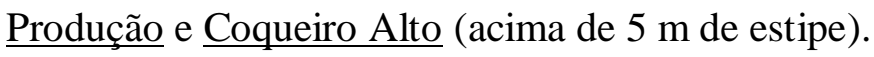

Comunidades quilombolas da Costa do Dendê, em Ituberá/BA, definem essas fases de forma mais simples, ou seja: Piaçava em Desenvolvimento; Piaçava em Produção; e Coqueiro em Produção.

As diferentes fases de desenvolvimento da piaçava, bem como o detalhamento de cada fase de desenvolvimento e produção, que vêm sendo usadas nas regiões de Santa Cruz de Cabrália, Porto Seguro e Ituberá. São apresentadas na Tabela 02. 
Tabela 02 - Detalhamento das fases de desenvolvimento e produção da palmeira de piaçava nas regiões de Santa Cruz de Cabrália, Porto Seguro e Ituberá.

\begin{tabular}{|c|c|c|}
\hline $\begin{array}{c}\text { FONTE } \\
\text { BIBLIOGRÁFICA }\end{array}$ & $\begin{array}{c}\text { FASE DE } \\
\text { DESENVOLVIMENTO }\end{array}$ & DETALHAMENTO \\
\hline \multirow{4}{*}{$\begin{array}{c}\text { Nomenclatura não } \\
\text { indígena adotada por } \\
\text { extrativistas do } \\
\text { Ponto Central (Sta. } \\
\text { Cruz Cabrália, BA) } \\
\text { - BERGAMO; } \\
\text { RODRIGUES } \\
\text { (2007) }\end{array}$} & Patioba & $\begin{array}{l}\text { Fase de plântula e muda da piaçava; Indivíduos } \\
\text { com até } 4 \text { anos de idade são conhecidos como } \\
\text { 'patioba'; Não há produção de fibras longas e } \\
\text { de qualidade para o uso, pois as fibras são finas } \\
\text { e pouco resistentes. }\end{array}$ \\
\hline & Piaçava Bananeira & $\begin{array}{l}\text { Estágio novo de desenvolvimento. Produção de } \\
\text { fibras longas e de qualidade produtiva para } \\
\text { uso. O caule subterrâneo que ainda não formou } \\
\text { estipe acima do solo, ainda não frutifica. } \\
\text { Indivíduos a partir de } 4 \text { anos de idade. }\end{array}$ \\
\hline & $\begin{array}{c}\text { Piaçava Coqueiro Recém } \\
\text { Formado }\end{array}$ & $\begin{array}{l}\text { Estágio jovem de desenvolvimento; Produção } \\
\text { de fibras longas e de qualidade produtiva. Já } \\
\text { formou estipe na superfície, mas ainda não está } \\
\text { exposto, ou está exposto com uma altura acima } \\
\text { do solo inferior a } 90 \mathrm{~cm} \text {. Nesse estágio inicia- } \\
\text { se a produção de frutos. }\end{array}$ \\
\hline & Piaçava Coqueiro & $\begin{array}{l}\text { Estágio adulto de desenvolvimento; Produção } \\
\text { de fibras longas e de qualidade produtiva. Tem } \\
\text { seu estipe formado e exposto acima de } 1 \text { metro } \\
\text { do solo e frutificando. }\end{array}$ \\
\hline \multirow{5}{*}{$\begin{array}{c}\text { Nomenclatura } \\
\text { indígena Pataxó } \\
\text { (Porto Seguro, BA) - } \\
\text { GAMA et al. (2009) }\end{array}$} & $\begin{array}{l}\text { Patioba (indivíduo } \\
\text { jovem) }\end{array}$ & $\begin{array}{l}\text { Fase inicial de desenvolvimento da planta; } \\
\text { muda com menos de um metro de altura. }\end{array}$ \\
\hline & Bananeira Nova & $\begin{array}{l}\text { Planta com folhas maiores que brotam do } \\
\text { tronco subterrâneo, tendo mais de um metro de } \\
\text { altura; Sem produção de fibra. }\end{array}$ \\
\hline & Bananeira em Produção & $\begin{array}{l}\text { Folhas brotando do tronco subterrâneo com } \\
\text { forma de um tronco de bananeira, chegando } \\
\text { atingir até } 15 \mathrm{~m} \text { de altura: Produção de fibra } \\
\text { comprida e fina. }\end{array}$ \\
\hline & Coqueiro em Produção & $\begin{array}{l}\text { Folhas brotando do tronco já desenvolvido, } \\
\text { chegando até } 20 \mathrm{~m} \text { de altura; Produção de fibra } \\
\text { curta e grossa. Fase de maior produção de } \\
\text { fibra. }\end{array}$ \\
\hline & Coqueiro Alto & $\begin{array}{l}\text { Plantas maiores que } 5 \mathrm{~m} \text { de estipe (tronco). } \\
\text { Plantas acima de } 25 \mathrm{~m} \text { de altura não devem ser } \\
\text { mais exploradas e sim destinadas à porta } \\
\text { sementes, pois os riscos de acidentes } \\
\text { aumentam, sobretudo queda do extrativista. }\end{array}$ \\
\hline \multirow{3}{*}{$\begin{array}{l}\text { Nomenclatura } \\
\text { adotada por } \\
\text { extrativistas e } \\
\text { quilombolas } \\
\text { (Ituberá, BA). }\end{array}$} & $\begin{array}{c}\text { Piaçava em } \\
\text { desenvolvimento }\end{array}$ & $\begin{array}{l}\text { Planta que ainda não produz fibras } \\
\text { comercializáveis. }\end{array}$ \\
\hline & Piaçava em produção & $\begin{array}{l}\text { Início da produção de fibras, estipe menor que } \\
2 \mathrm{~m} \text {. }\end{array}$ \\
\hline & Coqueiro em produção & Planta que produz frutos. \\
\hline
\end{tabular}

Em áreas nativas onde ocorrem as piaçavas os tratos silviculturais se restringem à extração e limpeza que ocorrem juntas, sendo a limpeza necessária a extração (GAMA et al., 2009). Segundo Silva; Vinha (1982) os tratos silviculturais feitos nas propriedades 
consistem em cortar a vegetação herbácea do sub bosque com finalidade única de abrir caminhos para as palmeiras durante a colheita.

Contudo os médios e grandes produtores que plantam a piaçava estão desenvolvendo um pacote tecnológico para domesticação da espécie. Guimaraes; Silva (2012) reuniram uma gama de informações sobre aspectos taxonômicos da espécie, reprodução, plantio (preparo de mudas), cultivo (nutrição, adubação, pragas e doenças), manejo, colheita, produtividade, domesticação e comercialização. Esses tratos silviculturais são colocados como procedimentos agronômicos, que consistem em: roçagem da área; coroamento das plantas; adubação das plantas; combate às pragas; combate às doenças, colheita propriamente dita; e limpeza da planta durante a colheita.

Informações sobre produção de piaçaveiras nas diversas fases do seu desenvolvimento são essenciais para a definição de estratégias de manejo da espécie. Tais informações podem ser tanto em termos de densidade (número de plantas por hectare) quanto a produção de fibra por planta ou quantidade de fibras produzida por hectare.

Alguns estudos já realizados em florestas naturais de piaçava, primárias e secundárias, bem como em áreas de plantio, são fontes de informações que podem auxiliar na definição de técnicas que visem o uso sustentável da espécie, tanto pelas comunidades tradicionais, quanto por agricultores familiares.

Hori (1970) verificou em seu estudo que a densidade de plantas de piaçava era bastante irregular em áreas de mata primária e secundária, sendo encontradas cerca de 300 plantas por hectare. Já nos "pontais" que são áreas anteriormente nativas que sofreram transformações pela queima da vegetação de maior porte e o incremento de novas plantas, a densidade pode subir a mais de 1.000 plantas por hectare (HORI, 1970).

Silva; Vinha (1982) realizaram estudo em três propriedades produtoras de piaçava, no município de Ilhéus, essas áreas apresentaram concentrações de 'piaçaveiras' com aproximadamente 1.600 plantas por hectare, sendo que 50\% delas tinham menos de 6 a 8 anos de idade e, estavam ainda em fase não produtiva. Os autores recomendam que a quantidade ideal de palmeiras por hectare deve estar em torno de 1.000 a 1.500 plantas, o que proporciona um espaçamento de 3 × 3 m entre 'piaçaveiras'. Nas áreas estudadas por Silva; Vinha (1982) foram registradas árvores pertencentes a cerca de 142 espécies e a densidade total nessas áreas foi, em média, igual a 2.660 árvores por hectare, em diferentes estágios de desenvolvimento. Dentre as espécies mais comuns, destacaram-se: janaúba, maçaranduba, mundururu-vermelho, pau pombo e carobinha. Os autores também observaram que a principal espécie herbácea associada a piaçava foi a tiririca. 
Outro estudo realizado por Silva e Vinha (1985), no Município de Canavieiras/BA, comparou piaçavas que ocorriam em dois ambientes distintos: interior de mata (floresta secundária) e área de campo aberto (capoeira). Os autores observaram que no interior da mata, a densidade foi, em média, igual a 440 plantas/hectare, sendo que deste total, 400 encontravam-se na fase de produção. Nas áreas de campo aberto foram registradas 960 plantas/hectare, e destas, 840 estavam em fase de produção. Na área de floresta secundária, as espécies arbóreas mais associadas às piaçavas foram: Tibouchina francavillana, Couepia sp e Neea sp. Na área de capoeira, o destaque foi para as espécies: Miconia calvescens e Tibouchina francavillana. Não foi observada a ocorrência de madeiras nobres nas duas áreas As espécies herbáceas com maior peso seco por metro quadrado nestas áreas foram a bananeirinha, na mata, e a tiririca, no campo aberto.

Em Santa Cruz Cabrália, Bahia, foi realizado um inventário florestal em nove áreas distintas da empresa de papel e celulose Veracel S.A. com objetivo de quantificar as piaçavas produtivas. O censo da piaçava apontou uma densidade populacional de 14 indivíduos produtivos por hectare (BERGAMO; RODRIGUES, 2007).

Estudo realizado por Silva; Guimarães (2006) registrou três povoamentos de piaçava na Bahia, contendo as maiores densidades de palmeiras. $\mathrm{O}$ povoamento mais denso, com 2.690 palmeiras por hectare, foi registrado no Município de Cairu, que é considerado um tradicional município produtor de fibras. $\mathrm{O}$ segundo maior povoamento de piaçava, com 1.626 palmeiras por hectare, foi registrado em Ilhéus, e o terceiro em Canavieiras, com 700 palmeiras por hectare. Considerando a densidade de piaçavas produtivas nesses três povoamentos, os autores observaram que as diferenças não foram tão grandes, variando de 870 plantas/ha em Cairu a 620 plantas/ha em Canavieiras. Esse mesmo estudo também apontou 840 plantas produtivas por hectare, em áreas abertas, e 400 em mata.

Gama et al. (2009) realizaram um levantamento de piaçavas na Reserva Indígena da Jaqueira (Povo Pataxó), Município de Porto Seguro/BA e registraram cerca de 402,3 plantas por hectare, em diferentes estágios de desenvolvimento. Esses autores verificaram ainda que na fase de coqueiro em produção, uma piaçaveira produz, em média, $5 \mathrm{~kg}$ de fibra bruta (fibra, borra ${ }^{10}$ e toco) por ano e, na fase de bananeira, a produção média é de 3 $\mathrm{kg}$ de fibra bruta por ano.

\footnotetext{
10 'Borra' e 'toco' são subprodutos da extração da piaçava. A 'borra' é a parte da 'capa' que envolve as fibras e é extraída em conjunto com esta, sendo separadas posteriormente. A 'borra' também é denominada de
} 
O levantamento realizado por Gama et al. (2009) apontou as seguintes estimativas de densidade por estágio de desenvolvimento da planta, ou seja: Patioba jovem (27\%), Patioba nova (25\%), Bananeira nova (19\%), Coqueiro em produção (26\%), Coqueiro alto $(1 \%)$ e planta normal (2\%). Os autores observaram ainda que a porcentagem de palmeiras de piaçavas nos diversos estágios de desenvolvimento estava bem equilibrada, pois, $45 \%$ das plantas estavam na fase reprodutiva (bananeira em produção e coqueiro em produção) e $52 \%$ estavam na fase inicial, vegetativa e sem produção de fibras e frutos (patioba e bananeira nova).

Esse levantamento (GAMA et al., 2009) apontou que na Reserva Indígena da Jaqueira havia grande quantidade de plantas realizando a reposição natural da espécie, não havendo necessidade, na época, de produção de mudas para reposição. Além disso, os autores verificaram que na fase de coqueiro, 27\% das plantas apresentavam danos, $13 \%$ estavam mortas e $60 \%$ não tinham sinais de danos. Os danos observados nas palmeiras podem ter sido causados durante a subida do coletor na palmeira, pois, nesta etapa de coleta das fibras da piaçava são feitos incisões no tronco (estipe) da planta. Com o tronco exposto ou machucado pelos cortes, o besouro causador da broca e o cupim, aproveitam-se das aberturas e danificam a planta, comprometendo assim com o desenvolvimento normal da planta.

Segundo Gama et al. (2009), as áreas manejadas pela comunidade indígena ainda correspondem, em sua maior parte, a áreas de mata, variando de estágios sucessionais secundários a clímax. O manejo tradicional da piaçava realizado pelo Povo Pataxó ainda não considera a etapa de plantio de piaçava, o que explica a baixa densidade de planta por hectare encontrada pelos pesquisadores.

Segundo Hori (1970), colheitas de fibras de piaçava feitas antes do tempo e intervalos curtos de colheita de fibras prejudicam áreas de cultivo e podem resultar em fibras de baixa qualidade. A condução de queimadas para limpeza, e outras operações comuns nas áreas de ocorrência de piaçavas, como a colheita por meio de incisão no estipe da palmeira, são fatores que diminuem a produtividade de um piaçaval.

Gama et al. (2009) afirmam que a perda de palmeiras de piaçava em áreas de extração está diretamente relacionada com a forma e intensidade de colheita da fibra. Tanto a exploração intensa quanto a alta densidade de plantas por unidade de área, são

'fita'. O toco é formado por pedaços menores de fibra e 'fita', que ficam presos na base dos pecíolos das folhas, oriundos da extração passada. 
prejudiciais, pois favorecem a ocorrência de doenças e insetos que causam a morte das plantas.

De acordo Bergamo; Rodrigues (2007), quando uma palmeira sofre qualquer dano provocado por cortes feitos no estipe durante a colheita das fibras, a planta pode ficar sujeita a "broca da ferida" - Rhynchophorus palmarum, pois o inseto aproveita o corte realizado na planta e se instala no seu interior.

Trabalhos similares aos citados acima não estão sendo desenvolvidos junto às comunidades quilombolas da Costa do Dendê, região também conhecida como extremo sul da Bahia. As instituições de pesquisa, extensão e apoio às atividades produtivas desenvolvem ações, trabalhos de desenvolvimento de tecnologias voltadas às espécies introduzidas como o cacau (Theobroma cacao), cupuaçu (Theobroma grandiflorum) e seringueira (Hevea brasiliense).

A maior quantidade de fibras em plantas jovens pode ser atribuída ao fato de que nestas plantas, toda a energia captada é alocada para a produção vegetativa, enquanto que numa piaçava adulta, grande parte da energia captada é alocada para a produção de flores e frutos. Nas plantas jovens, o comprimento das fibras foi $36 \%$ superior ao das plantas adultas, porém não foram observadas diferenças significativas quanto ao diâmetro das plantas.

Segundo Gama et al. (2009), a quantidade de fibras produzida pela piaçava é maior na fase 'coqueiro' e em áreas de capoeira, contudo, as fibras produzidas nesta fase são mais curtas e grossas, necessitando aproximadamente trinta 'capas' ${ }^{11}$ para produzir uma arroba de fibra bruta. Além disso, na fase 'coqueiro' a extração da fibra deve ocorrer em palmeiras com estipe de até 5 metros de altura. Palmeiras maiores não são colhidas, sendo destinadas para produção de sementes. Na fase 'bananeira', que ocorre mais em áreas de mata, a fibra é mais comprida e fina, necessitando de aproximadamente sessenta 'capas' para produzir uma arroba de fibra bruta.

De acordo com trabalhos científicos e relatórios técnicos (BONDAR, 1942; SILVA, 2002; CANTUÁRIA, 2008; GAMA et al., 2009) a produção média de fibra bruta por planta e por ano (Tabela 03) é igual a $5,5 \mathrm{~kg}$ de fibra vegetal bruta por planta.

\footnotetext{
${ }^{11}$ Capa é a denominação para o manto que recobre a fibra suja e a borra, produzida em cada folha. Neste caso se extraiu fibra em mais de 30 folhas para se conseguir uma arroba de fibra de piaçava bruta. Não se pode substituir por folha ou fibra bruta, pois o conjunto de fibras e borra formam uma capa, em cada folha.
} 
Tabela 03: Produção de fibra por planta $(\mathrm{kg})$

\begin{tabular}{|c|c|}
\hline Produção de fibra por planta (kg) & Autor \\
\hline 8 a 10 & BONDAR (1942a) \\
\hline 2,13 & MOREAU (1997) Mata $^{12}$ \\
\hline 3,08 & MOREAU (1997) Agrofloresta $^{5}$ \\
\hline 3,35 & MOREAU (1997) Pastagem \\
\hline 3,32 & MOREAU (1997) Plantio \\
\hline 1,81 & SILVA (2002) Bananeira Produção \\
\hline 1,28 & SILVA (2002) Coqueiro \\
\hline 1,5 a 3 & CANTUÁRIA (2008) \\
\hline 3 a 4 & GAMA (2009) \\
\hline
\end{tabular}

No estudo realizado por Bondar (1942), o ciclo de colheita da fibra em cada palmeira não era anual, portanto, possivelmente, um indivíduo não era explorado à mais de um ano, justificando assim a discrepância com os outros dados apresentados.

O estudo realizado por Silva (2002) trata da produção de fibras em plantas no estágio bananeira em produção e coqueiro, ou seja, plantas que já apresentavam inflorescência e apresentavam estipe maior que 1,5 m. A produção registrada por Silva (2002) refere-se a extração anual por planta.

De acordo com Moreau; Silva (1999), a produtividade média da piaçaveira, em quatro sistemas de manejo diferentes, variou entre 2,13 e 3,35 kg/planta. Plantas com maior produtividade foram encontradas no plantio e na pastagem, e plantas de menor produtividade foram registradas na mata. As fibras de $1^{\circ}$ qualidade representam aproximadamente $60 \%$ do peso total, as fibras de $2^{\circ}$ qualidade, $25 \%$ e a borra $16 \%$ (MOREAU; SILVA, 1999).

Segundo Cantuária (2008), a colheita de fibras de piaçava deve ser feita uma vez por ano, em qualquer época, cortando-se na base 2 a 4 folhas maduras onde a fita contendo a fibra e a borra (subproduto), desprende-se lateralmente do pecíolo. A planta deve estar no estágio 'bananeira'. Em áreas de ocorrência natural, onde predomina o extrativismo, a produtividade média é de $1,5 \mathrm{~kg}$ de fibra/planta e nas áreas plantadas a produtividade é de $3,0 \mathrm{~kg}$ de fibra/planta. Um trabalhador experiente chega a colher $45 \mathrm{~kg}$ de piaçava bruta/dia (rende $30 \mathrm{~kg}$ de material limpo). Uma planta de piaçaveira pode render de 8 a $10 \mathrm{~kg}$ de piaçava por ano e o tempo de exploração prolonga-se por 20 anos.

De acordo com Hori (1970), a colheita é feita a partir de talhos seqüenciais, em forma de escada na própria palmeira, o que não deixa de machucar a planta. Para execução

\footnotetext{
${ }^{12}$ Intervalo de extração de um ano, entre uma extração e outra.
} 
dessa tarefa, os homens utilizam ainda, escadas rústicas ou "peias", que são braçadeiras que facilitam a subida no tronco.

A piaçava é uma palmeira que não apresenta período certo de colheita, porém, a época considerada com melhores condições, corresponde ao período março/setembro (as chuvas se intensificam), segundo Costa; Santos (1985), em períodos mais quentes, a fibra colhida fica menos flexível. Contudo, são observadas colheitas em todos os meses do ano. A colheita também deve ser realizada apenas uma vez ao ano, o que permite a formação de fibras mais longas e de melhor valor comercial. Quando se faz a colheita ou corte com um intervalo menor que um ano, tem-se uma fibra de qualidade inferior, além de comprometer e longevidade da planta, com colheitas curtas e sucessivas (COSTA; SANTOS, 1985).

Para melhor comercialização, a fibra bruta da piaçava pode ser armazenada por mais de um ano, desde que seja em local seco, como, por exemplo, armazéns com assoalho de madeira (ZUGAIB; COSTA, 1988).

\section{4 - MATERIAL E MÉTODOS}

A meodologia adotada no levantamento de dados sobre o manejo florestal extrativista da piaçava englobou o acompanhamento da extração da fibra vegetal em áreas de plantio e área de ocorrência natural, diálogos (trocas) de saberes com os extratores especialistas através da pesquisa-ação (TRIPP, 2005), entrevistas gruiadas pelo roteiro semi-estruturado (Apendice A) feitas com pessoas chaves (especialistas), inventário florestal com amostragem aleatória simples (PÉLLICO-NETO, BRENA, 1997), inventário florestal quilombola e observações participantes, realizadas ao longo de 15 visitas às áreas pesquisadas, entre julho de 2012 a março de 2015 (Apendice B).

\subsection{1 - Área de Estudo}

Este estudo foi realizado em dois povoamentos de piaçava localizados nos municípios de Canavieiras e Ituberá, Estado da Bahia. O povoamento localizado no Município de Canavieiras pertence a uma propriedade particular com aproximadamente 300 ha. O segundo povoamento está localizado no Município de Ituberá, no Quilombo Brejo Grande, certificado pela Fundação Palmares (2005). A área encontra-se em processo de demarcação por isso não existe estimativa do tamanho da área total do quilombo. A Figura 06 ilustra a localização das duas áreas de estudo. 


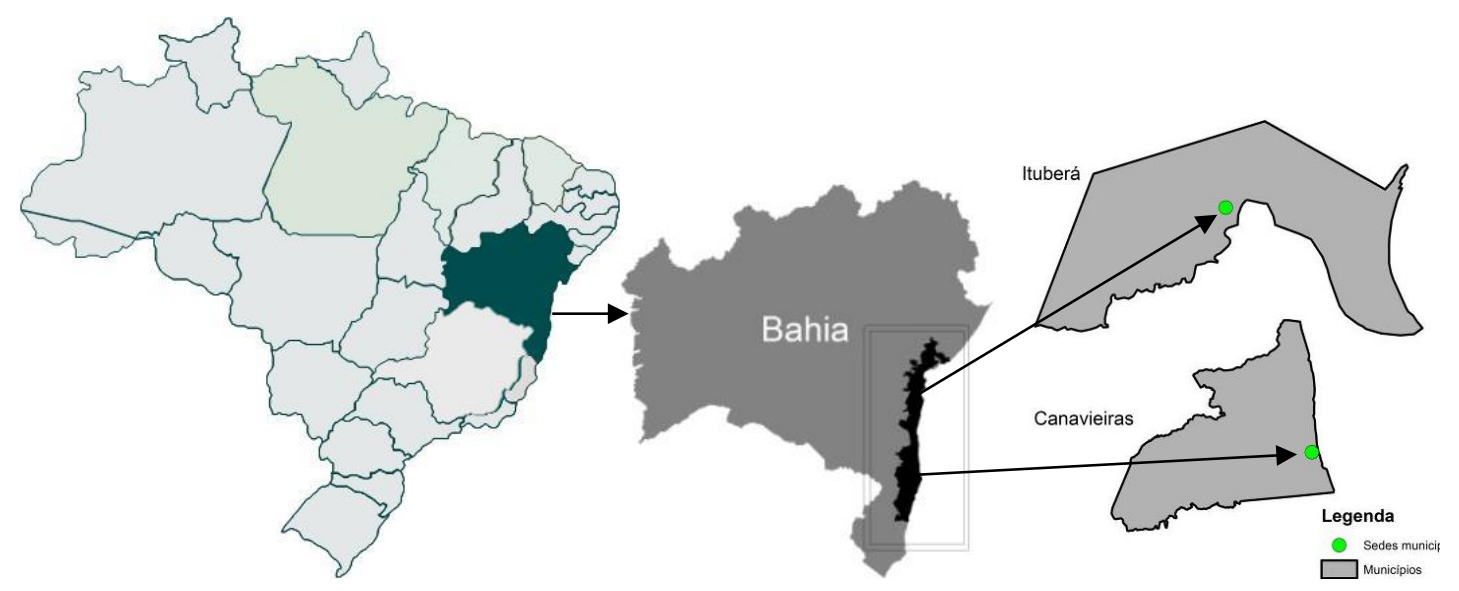

Figura 06: Localização das áreas de implantação das 11 parcelas amostrais.

As duas áreas de estudo estão afastadas da linha da costa baiana, a uma distância máxima de $60 \mathrm{~km}$, portanto, encontram-se dentro do limite de ocorrência natural da piaçava. O Quilombo Brejo Grande está localizado (coordenadas geográficas: S $13^{\circ}$ $42^{\prime} 07.9^{\prime}$ ' e W $39^{\circ} 12^{\prime} 11.1$ ') na zona rural do município de Ituberá, dista $17 \mathrm{~km}$ da sede do município. A Fazenda Nova Vida está localizada (coordenadas geográficas: S $15^{\circ} 46^{\text {' }}$ $37^{\prime \prime}$ W $\left.38^{\circ} 58^{\prime} 19^{\prime \prime}\right)$ na zona rural do município de Canavieiras, dista $20 \mathrm{~km}$ da sede do município.

Os dois povoamentos de piaçava foram formados pelos proprietários das terras ao longo dos últimos 50 anos. O Sr. Amâncio foi o primeiro a chegar à região do Quilombo Brejo Grande, comunidade Campo do Amâncio. Ele é o responsável por muitos dos plantios existentes no quilombo. Seus parentes, quando se referem a esse aspecto, dizem: “(...) ele plantou muitas matas de piaçava”.

A área quilombola está subdivida em pequenos plantios de piaçava de 1 a 8 ha (Figura 07), com idades variando entre 10 a 30 anos. A implantação das parcelas e o primeiro levantamento foi realizado em dezembro de 2013 e janeiro de 2014 . O segundo levantamento da produção de fibras por planta ocorreu em fevereiro de 2015.

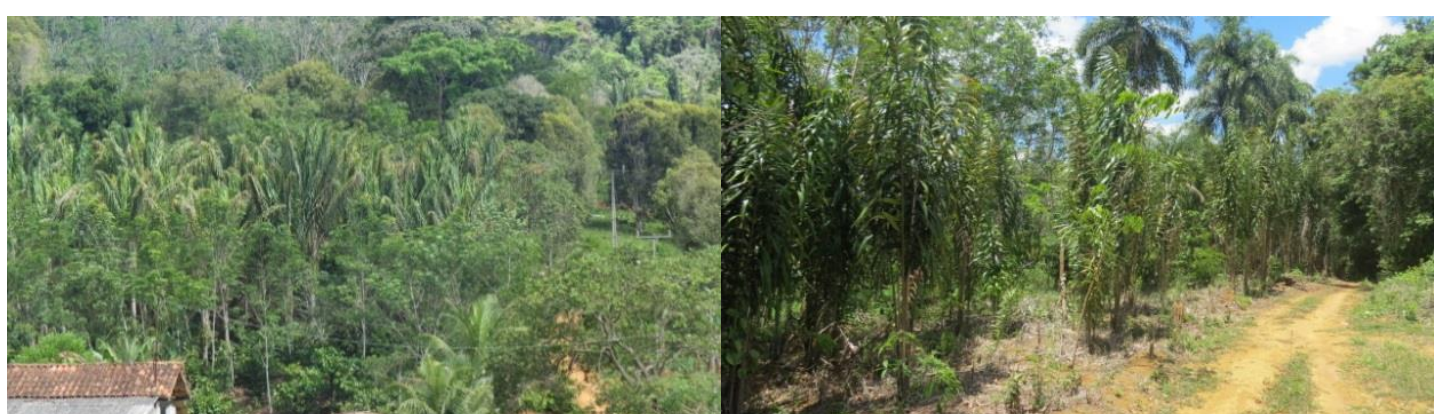

Figura 07: Plantios quilombolas de piaçava, localizados em Ituberá, BA. 
Na propriedade particular, o estudo foi realizado em um plantio com mais de 30 anos (Figura 08), ocupando uma área de 50 há. A implantação das parcelas e o primeiro levantamento foi realizado em outubro de 2013. O segundo levantamento da produção de fibras por planta ocorreu em fevereiro de 2015.

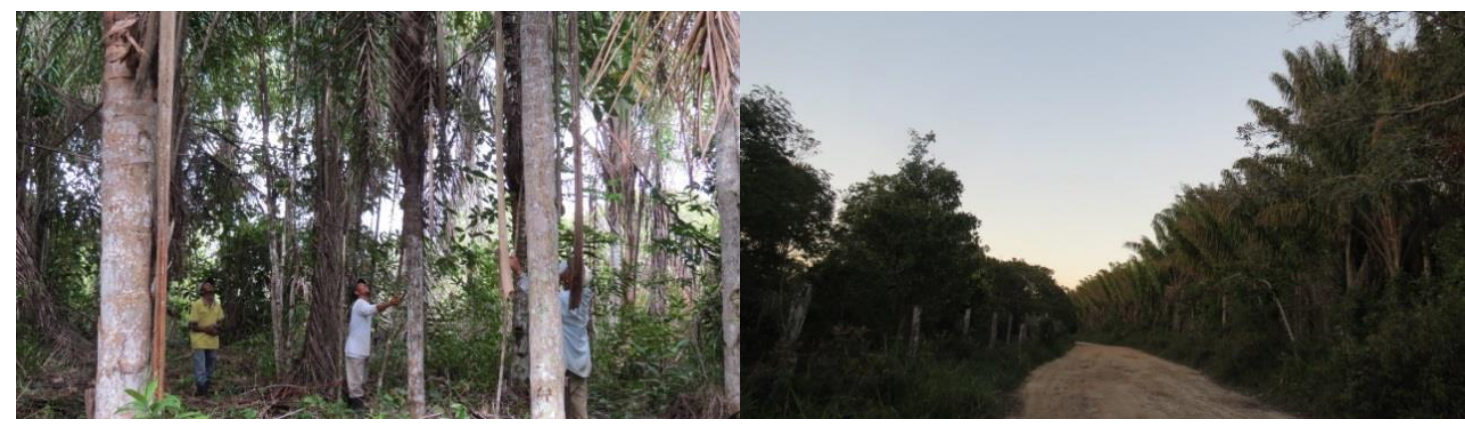

Figura 08: Plantios de Piaçava em Canavieiras, BA.

Ambos os povoamentos foram implantados a partir do plantio direto de sementes adquiridas em fragmentos de florestas nativas. As áreas foram abertas para este fim e, na propriedade particular o espaçamento utilizado foi $3 \times 3$ e $4 \times 4$. No quilombo o espaçamento utilizado nos plantios quilombolas é medida empírica, ou seja, espaçamento feito "no olho" no momento do plantio.

A região situada entre as costas do Dendê e do Cacau estão inseridas em um clima tropical chuvoso, classificação de Koppen (Af e Aw), temperatura mais baixa superior a $18^{\circ} \mathrm{C}$, com verões longos e quentes e temperaturas médias maiores que $22^{\circ} \mathrm{C}$. Solos Latossolos e Podzólicos, os quais, embora sejam profundos e típicos de clima úmido, são, na sua maioria, de baixa fertilidade natural. As Areias Quartzosas marinhas podem ser encontradas em grandes faixas, composta por vegetação de restinga ou ainda afloramentos (IDES, 2004).

\subsection{2 - Amostragem}

Devido às especificidades das áreas quilombolas, principalmente a falta de definição da área total do quilombo, mas também a organização social e produtiva do Quilombo Brejo Grande, onde cada família possui pequenos plantios de piaçava em suas áreas e, esses plantios estão espalhados pelo território quilombola, próximos aos roçados, plantios de cacau, seringueiras e/ou remanescentes de Mata Atlântica. Adotou-se uma amostragem preferencial, onde a alocação das parcelas foram feitas exatamente nas "matas de piaçava". Outro critério adotado para alocação das parcelas está relacionado ao ciclo de 
extração das plantas, foram selecionadas as áreas onde a extração de fibra bruta ocorreu a mais de 12 messes atrás. Entre àquelas parcelas que se adequaram a essas condições, o critério seguinte foi interesse ou não do quilombola em participar da pesquisa.

Desta forma, o primeiro passo, para mensurar o estoque produtivo de piaçava da área do Quilombo Brejo Grande, foi obter a descrição falada do território quilombola, através da metodologia proposta por Machado (2008), ou seja, a elaboração do mapa falado ou mental da área quilombola.

O croqui da área quilombola foi elaborado em uma reunião no Quilombo Brejo Grande, com as principais lideranças envolvidas na produção de piaçava, caçadores e jovens extratores. Durante a reunião foi possível catalogar todos os plantios de piaçava do quilombo, entender a distribuição espacial no croqui elaborado e obter a estimativa de área (hectare) de cada plantio de piaçava, conforme descrição apresentada na Tabela 04.

No total foram catalogados 41 plantios de piaçava no Quilombo Brejo Grande, sendo 40 plantios com área variando de 0,5 a 8 ha e um plantio com 15 ha (plantio $\mathrm{n}^{0} 06$ ). O plantio com área de 15 ha pertence ao Sr. Diorge e está dentro de uma área de 52 ha, adquirida de uma das famílias quilombolas. Esse plantio foi desconsiderado da pesquisa por não ser, atualmente, um plantio quilombola. Após a demarcação do território quilombola, essa área será reincorporada.

Entre as famílias quilombolas, as distribuições dos 40 plantios de piaçava ficaram da seguinte forma: dezoito famílias com plantio ocupando área de 1 ha (a); treze famílias com plantio de 2 ha (b); uma família com 3 ha (c); quatro famílias com 4 ha (d); uma família com 5 ha (e); uma família com 8 ha (f); uma família com 1,5 ha (g) e uma família com 0,5 ha (h), segundo informações dos extrativistas. Neste estudo foi considerado um total de 78 ha de área plantada com piaçava no Quilombo Brejo Grande, ou seja, os 93 ha menos os 15 ha do plantio 06. Desconsiderou-se esse plantio 06, pois, o Sr. Diorge não se considerada quilombola e os quilombolas também não o reconhece como tal.

Tabela 04: Área (ha) dos plantios de piaçava do Quilombo Brejo Grande

\begin{tabular}{|c|c|c|c|}
\hline $\mathrm{N}^{\circ}$ & Plantio de Piaçava do Sr. ou Sra. & Tamanho (ha) & Categoria \\
\hline 1 & Cal 40 há & 4 & $\mathrm{~d}$ \\
\hline 2 & Agnaldo & 4 & $\mathrm{~d}$ \\
\hline 3 & João & 2 & $\mathrm{~b}$ \\
\hline 4 & André & 4 & $\mathrm{~d}$ \\
\hline 5 & Elias & 2 & $\mathrm{~b}$ \\
\hline 6 & Diorge -52 ha & 15 & - \\
\hline 7 & Amâncio & 2 & $\mathrm{~b}$ \\
\hline 8 & Carlos & 0,5 & $\mathrm{~h}$ \\
\hline
\end{tabular}




\begin{tabular}{|c|c|c|c|}
\hline 9 & Lió & 2 & $\mathrm{~b}$ \\
\hline 10 & Mane Ângelo & 1 & $\mathrm{a}$ \\
\hline 11 & Domingos & 1 & $\mathrm{a}$ \\
\hline 12 & Liotéro & 2 & $\mathrm{~b}$ \\
\hline 13 & Manoel Dison & 2 & $\mathrm{~b}$ \\
\hline 14 & Evandro & 4 & $\bar{d}$ \\
\hline 15 & Zé Rocha & 1 & $\mathrm{a}$ \\
\hline 16 & Manoel Siríaco & 1 & $\bar{a}$ \\
\hline 17 & Aloísio de Jesus - 10 há & 1 & $\bar{a}$ \\
\hline 18 & Antônio Conceição - 50 há & 2 & $\mathrm{~b}$ \\
\hline 19 & Nelson & 1 & a \\
\hline 20 & Domingo Rosário & 2 & $\mathrm{~b}$ \\
\hline 21 & Domingo Araújo & 2 & $\mathrm{~b}$ \\
\hline 22 & Ducan & 1,5 & $\mathrm{~g}$ \\
\hline 23 & Emília & 1 & $\mathrm{a}$ \\
\hline 24 & Braz & 2 & $\mathrm{~b}$ \\
\hline 25 & Antônio Francisco & 2 & $\mathrm{~b}$ \\
\hline 26 & André Ricardo - 50 há & 2 & $\mathrm{~b}$ \\
\hline 27 & Antônia das Neves & 1 & a \\
\hline 28 & Domingo Mantídeo & 2 & $\mathrm{~b}$ \\
\hline 29 & Francisco & 3 & $\mathrm{c}$ \\
\hline 30 & Cosme - 15 há & 1 & a \\
\hline 31 & Sabina & 1 & $\mathrm{a}$ \\
\hline 32 & Damiana Anja & 1 & $\mathrm{a}$ \\
\hline 33 & Antônio de Novaes & 1 & $\mathrm{a}$ \\
\hline 34 & Maria Caetano & 1 & $\mathrm{a}$ \\
\hline 35 & Pedro - 3 há & 1 & $\mathrm{a}$ \\
\hline 36 & Mabo - 25 há & 1 & $\mathrm{a}$ \\
\hline 37 & André da Moto & 1 & $\mathrm{a}$ \\
\hline 38 & Aurélio & 1 & $\mathrm{a}$ \\
\hline 39 & Adonia Conceição dos Santos & 8 & $\mathrm{f}$ \\
\hline 40 & Adelino & 5 & $\mathrm{e}$ \\
\hline 41 & Zeu & 1 & $\mathrm{a}$ \\
\hline
\end{tabular}

A partir da definição da área total de plantios de piaçava no quilombo, foi realizado o agrupamento dos plantios que não sofreram extração da fibra a mais de um ano. Entre esses plantios, deu-se preferência para as famílias quilombolas que queriam participar da pesquisa e se comprometeram a não fazer extrações de fibras, dentro das áreas de estudo (parcelas implantadas nas áreas), até início de 2015.

Respeitando esses critérios, foram selecionados cinco plantios, no Quilombo Brejo Grande de Ituberá, visando a atender os objetivos do estudo. As parcelas foram alocadas dentro dos plantios selecionados, somente em um plantio, atualmente do Sr. Liotério, foram alocadas duas parcelas, conforme Tabela 05. Portanto foram implantadas seis parcelas, cada parcela com dimensões de $20 \mathrm{~m}$ x $20 \mathrm{~m}\left(400 \mathrm{~m}^{2}\right)$, totalizando $2.400 \mathrm{~m}^{2}(0,24$ ha) amostrados, que correspondem a, aproximadamente, $0,31 \%$ da área total amostrada (78 ha). 
Tabela 05: Identificação do plantio e tamanho da área (ha) e idade dos plantios de piaçava selecionados no Quilombo Brejo Grande.

\begin{tabular}{|c|c|c|c|c|}
\hline $\mathrm{N}^{\circ}$ & Plantio de Piaçava do Sr. ou Sra. & Tamanho (ha) & ${\text { Parcela } \mathrm{N}^{\circ}}$ & Idade (anos) \\
\hline 10 & Manoel Ângelo & 1 & 06 e 11 & $30-40$ \\
\hline 12 & Liotério & 2 & 07 & $40-50$ \\
\hline 17 & Aloísio & 10 & 08 & 14 \\
\hline 30 & Cosme & 1 & 09 & 7 \\
\hline 32 & Damiana & 1 & 10 & 18 \\
\hline
\end{tabular}

$\mathrm{Na}$ propriedade particular, localizada no Município de Canavieiras, foi disponibilizada uma área de 50 ha de plantio de piaçava para desenvolvimento deste estudo. Nesta área, optou-se pela realização de inventário florestal com amostragem aleatória simples (PÉLLICO-NETTO; BRENA, 1997), sendo alocadas aleatoriamente 5 parcelas de $20 \mathrm{~m}$ x $20 \mathrm{~m}\left(400 \mathrm{~m}^{2}\right)$ que corresponderam a 0,4\% da área total. A Figura 09 apresenta o mapa com a localização da propriedade e das parcelas alocadas.

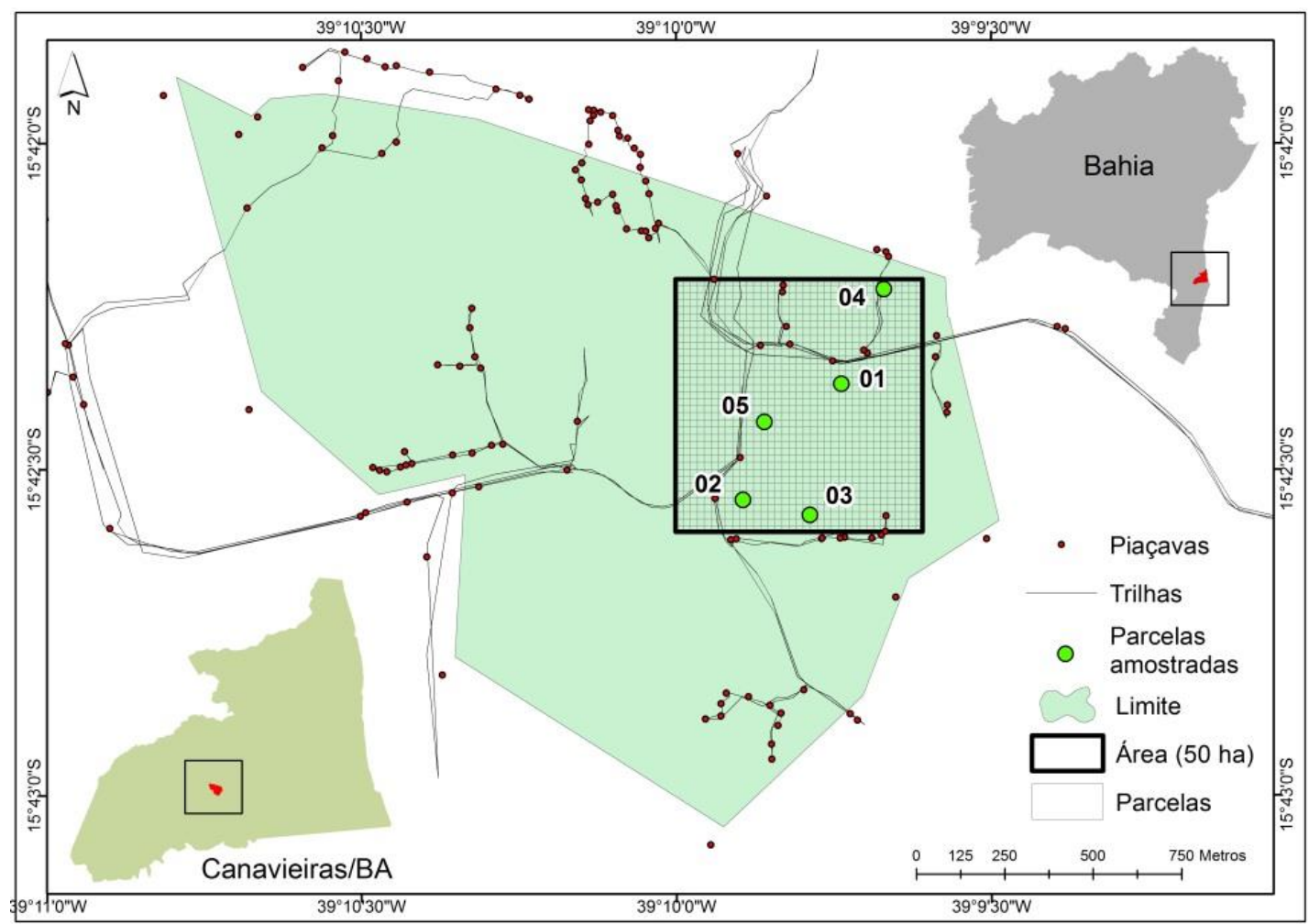

Figura 09: Mapa com alocação das parcelas dentro dos 50 hectares da propriedade.

É importante destacar que em cada área de estudo foi adotado um sistema de amostragem distinto principalmente para testar metodologias novas e, também devido aos seguintes fatores: realidade do local, informações disponíveis, equipe de campo, recursos disponíveis e tempo para o levantamento e coleta de dados (Tabela 06). 
Tabela 06: Sistemas de manejo e amostragem adotados

\begin{tabular}{|c|c|c|c|c|c|}
\hline $\begin{array}{c}\text { Sistema } \\
\text { Manejo }\end{array}$ & $\begin{array}{c}\text { Área Total } \\
\text { (ha) }\end{array}$ & $\begin{array}{c}\mathrm{N}^{\circ} \text { Parcelas } \\
(20 \times 20 \mathrm{~m})\end{array}$ & $\begin{array}{c}\text { Área } \\
\text { Amostrada } \\
\left(\mathrm{m}^{2}\right)\end{array}$ & $\begin{array}{c}\text { Área } \\
\text { Amostrada } \\
\text { (ha) }\end{array}$ & $\begin{array}{c}\text { Área } \\
\text { Amostrada } \\
\%\end{array}$ \\
\hline Quilombo $^{\mathrm{a}}$ & 78 & 6 & 2.400 & 0,24 & 0,31 \\
\hline Propriedade $^{\mathrm{b}}$ & 50 & 5 & 2.000 & 0,2 & 0,40 \\
\hline
\end{tabular}

a:Inventário Florestal com amostragem preferencial; b:Inventário Florestal com amostragem aleatória.

A área total amostrada foi de $22.727,27 \mathrm{~m}^{2}$ ou 0,44 ha somando as áreas de Ituberá e de Canavieiras. Totalizaram 11 parcelas amostradas. Nessas 11 parcelas foram mensuradas 466 plantas. Entre essas plantas foram aleatoriamente selecionadas 42 plantas na fase de produção de fibra vegetal para ser realizada a $1^{\circ}$ extração (outubro de 2013 em Canavieiras e janeiro de 2014 em Ituberá). A $2^{\circ}$ extração foi realizada em 28 plantas dessas 42 plantas produtoras de fibra vegetal, no mês de fevereiro de 2015, em ambas as áreas.

\subsection{3 - Coleta de Dados}

Considerando o saber indígena (GAMA et al., 2009), quilombola, contribuições técnicas do inventário realizado pela empresa de papel Veracel (BERGAMO; RODRIGUES, 2007) com a população extrativista do Ponto Central, somado as informações levantadas no âmbito desta pesquisa de doutorado, agrupou-se as palmeiras em quatro estágios diferentes (Tabela 07). Essa divisão adotada nesta tese simplifica as fases de desenvolvimento da palmeira, a fim de facilitar o dia a dia do processo produtivo, respeitando as diferenças fundamentais quanto ao estoque de plantas por área e por planta, voltado aos pequenos e médios plantios de piaçava.

Tabela 07: Fases de Desenvolvimento da Palmeira de Piaçava adotada neste estudo:

\begin{tabular}{|c|c|}
\hline Fase de desenvolvimento & Detalhamento \\
\hline Patioba & Plântula e muda da piaçava. Não produz fibras. \\
\hline Bananeira Nova & $\begin{array}{c}\text { Palmeira com fibras não adequadas para o uso, tanto } \\
\text { pela quantidade e qualidade da fibra quanto pela } \\
\text { fragilidade da planta. Caule subterrâneo, onde os } \\
\text { longos pecíolos das folhas formam o tronco, } \\
\text { conhecido como bananeira. }\end{array}$ \\
\hline $\begin{array}{c}\text { Bananeira em Produção } \\
\text { BP }\end{array}$ & $\begin{array}{c}\text { Palmeira que produz fibra com qualidade para o uso. } \\
\text { Planta com porte maior. Algumas apresentam estipe } \\
\text { aparente. Não produzem frutos. }\end{array}$ \\
\hline Coqueiro & Palmeira adulta. Apresenta estipe, produz fibras e \\
COQ & frutos. \\
\hline
\end{tabular}

Nas parcelas de $20 \times 20$ m amostradas em cada área de estudo (área quilombola e área particular), foram coletadas as seguintes informações: 
- Contagem de todos os indivíduos de piaçava (censo) - os indivíduos foram identificados com placas contendo um número;

- Classificação do estágio de desenvolvimento da palmeira: patioba; bananeira nova, bananeira em produção e coqueiro;

- Altura total estimada e altura do estipe de cada palmeira - medição realizada com vara graduada;

- Contagem do número de folhas abertas, fechadas e secas;

- Contagem do número de 'capas' e 'tocos';

- Diâmetro à altura do peito (DAP), tomado a 1,30 m do solo - medição realizada com fita diamétrica;

- Diâmetro da base (Db), tomado a 0,30 m do solo, obtido para cada palmeira medição realizada com fita diamétrica;

- Registro da presença ou ausência de incisões no estipe da palmeira;

- Registro da presença de 'busa' (inflorescência fechada), flores, frutos e número de cachos por planta; e estado geral de saúde da palmeira; e

- Registro dos tempos para subir na palmeira e extrair a fibra bruta.

Após a coleta das informações descritas acima, em cada uma das 11 parcelas amostradas, procedeu-se a seleção aleatória de duas palmeiras em duas fases de desenvolvimento diferentes, ou seja, bananeira em produção (BP) e coqueiro (COQ), em cada parcela amostrada.

A seleção se deu a partir do sorteio das palmeiras presentes em cada parcela.

Em cada palmeira selecionada, efetuou-se a extração das fibras e, em seguida, definiu-se a massa de fibras brutas e 'tocos' ${ }^{13}$ extraídos de cada palmeira. Foi realizada também a medição do comprimento das fibras e dos 'tocos', bem como a medição de 22 folhas e contagem dos frutos em três cachos de cada palmeira.

Foi realizado também o censo dos regenerantes da piaçava (patioba) em cada uma das 11 parcelas, sendo mensuradas as seguintes variáveis: altura total e número de folhas.

O material botânico da piaçava da Bahia foi coletado no Quilombo Brejo Grande no dia 12 de dezembro de 2013 e posteriormente incorporado ao acervo do Herbário da Universidade Estadual de Santa Cruz (UESC), campus de Ilhéus, Bahia. Uma duplicata foi

\footnotetext{
${ }^{13} \mathrm{O}$ toco é formado por pedaços menores de fibra e 'fita', que ficam presos na base dos pecíolos das folhas, pedaços de 'capas' deixados na palmeira durante a extração passada.
} 
encaminhada ao acervo do Herbário do Instituto de Biologia, Departamento de Botânica UnB.

\subsection{4 - Análise dos Dados}

\subsubsection{1 - Análise da precisão da amostragem}

Foi avaliada a precisão do inventário realizado nas áreas de estudo, o qual buscou quantificar o potencial produtivo dos dois plantios. Nessa avaliação foram consideradas em cada plantio, área particular (AP) e área quilombola (QUI), as variáveis número de palmeiras por hectare e número de folhas abertas (verdes e secas) de plantas saudáveis por hectare. A escolha das duas variáveis se justifica pelo fato da produção de fibras de piaçava estar diretamente relacionada com a quantidade de folhas saudáveis em uma palmeira, bem como a densidade do plantio, além da fase de desenvolvimento da planta.

No caso da densidade, a precisão do inventário foi avaliada considerando tanto a amostragem de todas as palmeiras nas parcelas, independente da fase de desenvolvimento, quanto à amostragem apenas das palmeiras em fase de produção, isto é, 'bananeira em produção - BP' e 'coqueiro - COQ'.

O erro amostral ou precisão do inventário foi obtido conforme Péllico Netto; Brena (1997), ou seja:

$$
E(\%)=\frac{t . s \bar{x}}{\bar{x}} .100
$$

em que:

$\mathrm{E}(\%)=$ precisão ou erro amostral do inventário, em percentagem;

$\mathrm{t}=$ valor de $\mathrm{t}$ tabelado considerando um nível de significância de 5\%;

$S_{\bar{x}}=$ erro padrão da média da variável de interesse;

$\bar{X}=$ valor médio da variável de interesse.

O valor do erro padrão da média foi obtido a partir da seguinte relação:

$$
S_{\bar{X}}=\sqrt{\frac{\sum_{i=1}^{n}\left(x_{i}-\bar{x}\right)^{2}}{n(n-1)} \cdot(1-f)}
$$

em que:

$\mathrm{x}_{\mathrm{i}}=$ valor observado da variável de interesse na parcela $\mathrm{i}$; 
$\mathrm{f}=$ fator de correção $=1-\frac{n}{N}$;

$\mathrm{n}=$ número de parcelas amostradas;

$\mathrm{N}$ = número total de parcelas cabíveis em toda área.

\subsubsection{2 - Análise estatística descritiva das variáveis relacionadas à produção da piaçava}

A partir das informações coletadas nas parcelas de cada área estudada, foi realizada a análise estatística descritiva dos dados, considerando as fases de desenvolvimento da piaçava, principalmente as fases produtivas , $\mathrm{BP}$ e $\mathrm{COQ}$.

A estatística descritiva incluiu tanto as medidas de posição (média, valor máximo e valor mínimo), quanto medidas de variação (coeficiente de variação - CV e intervalo de confiança - IC) dos dados.

As seguintes variáveis foram analisadas: altura total estimada (HT), altura do estipe (HE), número de folhas com capas (NFC), número de folhas com toco (NFT), diâmetro da palmeira tomado a $1,30 \mathrm{~m}$ do solo (DAP) e diâmetro da palmeira tomado na base, à $0,30 \mathrm{~m}$ do solo $(\mathrm{Db})$.

As médias de todas as variáveis analisadas, nas fases produtivas da piaçava (BP e COQ) e, em cada local estudado (AP e QUI), foram comparadas utilizando o Teste t de Variância Combinada (ZAR, 2009), considerando um nível de significância igual a 5\%.

A estatística de t de variância combinada é dada por:

$$
t=\frac{\left(\bar{X}_{1}-\bar{X}_{2}\right)-\left(\mu_{1}-\mu_{2}\right)}{\sqrt{S_{p}^{2} \cdot\left(\frac{1}{n_{1}}+\frac{1}{n_{2}}\right)}},
$$

em que:

$$
S_{p}^{2}=\frac{\left(n_{1}-1\right) S_{1}^{2}+\left(n_{2}-1\right) S_{2}^{2}}{\left(n_{1}-1\right)+\left(n_{2}-1\right)}
$$

$S_{p}^{2}=$ variância combinada;

$\bar{X}_{1}=$ média aritmética da amostra tomada na área 1 ;

$\bar{X}_{2}=$ média aritmética da amostra tomada na área 2 ;

$\mu_{1}=$ média aritmética de toda a população 1 ;

$\mu_{2}=$ média aritmética de toda a população 2 ;

$S_{1}^{2}=$ variância da amostra tomada na área 2 ;

$S_{2}^{2}=$ variância da amostra tomada na área 2 ;

$n_{1}=$ número de dados coletados na amostra 1 ;

$n_{2}=$ número de dados coletados na amostra 2 . 


\subsubsection{3 - Modelagem da produção de fibras de piaçava}

Em geral a produção em volume de uma árvore é bastante influenciada por variáveis como diâmetro (DAP ou Db), altura (total ou do fuste), forma da árvore e idade da árvore. Contudo, outras variáveis também podem influenciar na produção volumétrica de uma árvore, como, por exemplo, variáveis relacionadas à estrutura da floresta, como densidade e área basal, e, variáveis ambientais, como solo, clima etc (JONES, 1969).

O uso de modelos matemáticos que estimem a produção volumétrica de árvores é bastante comum na área florestal e é essencial na elaboração de planos de manejo florestal.

No caso de palmeiras, como a piaçava, que é o objeto deste estudo, não foram encontrados registros de estudos envolvendo ajuste de modelos de regressão visando estimar a produção de fibras brutas (PFB) e, tal como ocorre para as árvores de uma floresta, o uso de modelos de regressão deve ser empregado para estimar a produção de produtos de uma palmeira, tais como fibras, frutos etc, sendo, portanto é de grande importância na elaboração de qualquer estratégia de manejo para plantios desta espécie.

Desta forma, para atender este objetivo, em cada parcela amostrada de cada área de estudo (AP e QUI), foram selecionadas aleatoriamente duas bananeiras em produção (BP) e dois coqueiros de piaçava (COQ). Uma única exceção foi dada para uma parcela amostrada na área quilombola, com 7 anos de idade, onde não foi registrado nenhum coqueiro. Nesta parcela foram selecionadas apenas duas bananeiras em produção (BP).

A seleção de duas plantas em cada fase de desenvolvimento da piaçava (BP e COQ) tomou como base a definição do termo altura dominante (HDOM), que é uma variável altamente correlacionada com a produção florestal e que representa a altura média de 100 plantas de maior diâmetro em um hectare (JONES, 1969). Esta é uma variável muito utilizada na classificação de sítios florestais e, por esta razão, buscou-se adaptar essa definição para as condições deste estudo, em que as plantas são palmeiras produtivas.

Após escolher as 4 (quatro) palmeiras de maior diâmetro (2 $\mathrm{BP}$ e $2 \mathrm{CO}$ ) em cada parcela, foi obtida a altura dominante das mesmas e determinado a produção de fibras brutas (PFB), em quilos, extraída em cada palmeira.

Antes de se testar modelos de regressão para estimativa da produção de fibras brutas de piaçava, foi realizada uma análise de correlação das variáveis, com o objetivo de verificar que variáveis estariam mais correlacionadas com a PFB por planta. As variáveis testadas foram: HDOM, Idade média do plantio, Número de Folhas Verdes Abertas (NFA), 
DB e DAP. Além disso, também foram testadas todas estas variáveis transformadas, como, por exemplo, $\mathrm{DAP}^{2}, \mathrm{DB}^{2}, \mathrm{LN}(\mathrm{DAP}), \mathrm{LN}(\mathrm{DB}), \mathrm{LN}(\mathrm{HDOM})$, entre outras.

Após a definição das variáveis mais relacionadas com a produção de fibras, foram ajustados modelos de regressão linear, visando estimar PFB em função de determinada ou de determinadas variáveis independentes.

Do total de palmeiras selecionadas para determinar a PFB, foi separado um número de plantas para serem utilizadas na validação dos modelos.

Os critérios utilizados para a escolha do melhor modelo, segundo Drapper; Smith (1981), foram:

a) exame do quadro de análise de variância;

b) análise das medidas de precisão: coeficiente de determinação ajustado $\left(\mathrm{R}^{2}\right.$ ajustado), e erro padrão da estimativa expresso como uma percentagem da média aritmética da variável dependente $(\mathrm{Syx} \%)$, sendo, neste caso, interpretado de forma análoga ao coeficiente de variação;

c) distribuição gráfica dos valores residuais.

Para validar a precisão do modelo selecionado foi feito o teste diferença agregada e o erro da estimativa (\%), os quais são tradicionalmente utilizado quando se deseja examinar se uma técnica de predição gera valores estatisticamente iguais ao valor real da variável de interesse.

\subsubsection{4 - Eficiência do manejo extrativista da fibra vegetal na área quilombola e na área particular}

Para avaliar a eficiência das técnicas e tecnologias de manejo dos produtos florestais não madeireiros oriundos da piaçava, que vem sendo adotadas tanto na terra quilombola quanto na área particular, foram consideradas: as atividades relacionadas à extração da fibra da piaçava nos dois plantios; as entrevistas realizadas com os extrativistas (Apêndice A), com foco nas etapas de subida na palmeira, extração das fibras, arraste, transporte e armazenamento dos feixes de fibra suja, dentro das áreas de exploração da fibra e também as informações geradas pelo inventário realizado nas duas áreas.

O método aqui proposto, para se obter a produtividade por área e por planta, visa contribuir com novas propostas de metodologias, embasadas cientificamente, acessíveis 
aos técnicos e comunidades tradicionais, para quantificar e qualificar às áreas de piaçava, averiguar o potencial produtivo de produtos florestais não madeireiros.

A produtividade do plantio é uma variável importante para gestão da atividade produtiva da piaçava que deve ser mensurada de forma simples e mais precisa possível

\section{5 - RESULTADOS E DISCUSSÃO}

O manejo florestal tradicional que ocorre no quilombo Brejo Grande de Ituberá está relacionado à experiência de quilombolas, ainda vivos, que acreditavam no valor econômico dessa palmeira nativa, há mais de 50 anos atrás iniciaram os plantios, por volta de 1960. Esses quilombolas e demais produtores de piaçava não receberam apoio para fazer plantios, ou enriquecer áreas já abertas da Mata Atlântica, com essa espécie florestal. As iniciativas são isoladas, mesmo entre os quilombolas que possuem o saber tradicional dos múltiplos usos da espécie. Atualmente existem 78 ha de área plantada com piaçavas da Bahia no Quilombo Brejo Grande. Foram plantadas de forma descontínuas e são estimadas em aproximadamente 97.500 palmeiras de piaçava, entre essas palmeiras 80.925 plantas estão produzindo fibras brutas (BP e COQ) e 24.375 estão na fase de desenvolvimento coqueiro (COQ).

O manejo florestal da piaçava realizado na Fazenda Nova Vida, da família Francisco da Silva Matos, em Canavieiras, também foi implantado por volta 1960 quando a extrações de fibra bruta era exclusivamente de áreas nativas. O produtor foi adquirindo áreas a oeste da costa e, fazendo o plantio das áreas, deixando aos herdeiros atuais, aproximadamente 500 ha de área. Esses herdeiros ainda não fizeram o levantamento da área plantada com piaçava, estimam, sem muita precisão, que são aproximadamente 200 ha plantados com piaçava. Considerando os 50 ha de área, onde foi permitida a implantação das parcelas dessa pesquisa de doutorado, nesta área existem aproximadamente 41.750 plantas, sendo 27.250 plantas produtoras de fibra vegetal (BP e COQ) e 20.250 plantas estão na fase de desenvolvimento de coqueiro (COQ).

O manejo florestal da piaçava deve compreender as etapas de extração da fibra bruta ate a reposição da matéria prima nas áreas manejadas. Essas etapas consistem no planejamento da extração da fibra vegetal ou fruto da palmeira; limpeza dos acessos e áreas de extração; divisão das áreas de extração entre o grupo de extratores; extração da fibra vegetal (equipamentos de proteção e segurança individual) arraste das capas até as 
vias de acesso mais próximas às áreas de extração; formação dos feixes de fibras brutas e transporte da matéria prima. A reposição das palmeiras de piaçava corresponde às etapas de produção de mudas, plantio direto e/ou enriquecimento de áreas da Mata Atlântica; tratos silviculturais em plantios recém-formados como o coroamento das mudas; seleção de matrizes que produzem fibras com padrões desejados, matrizes com grande produção de frutos com as características desejadas e marcação para evitar a coleta de frutos dessas plantas.

A exploração de fibras vegetais da inicia entre 07 a 10 anos após o plantio, quando a planta atingiu a fase de bananeira em produção (BP). Nesta fase de desenvolvimento a plantação recebe muita insolação e o crescimento de plantas herbáceas é intenso. A redução de plantas herbáceas se dá com o crescimento das palmeiras.

Em áreas com plantios de piaçava predominam a espécie cultivada, mas, também ocorrem outras espécies nativas da Mata Atlântica. Com a passar do tempo, quando o plantio completa seus 30 anos e a maioria dos indivíduos de palmeira já estiver na fase de coqueiro (COQ), apresentando frutificação, pode-se iniciar o aproveitamento dos frutos na unidade de exploração. A falta de luminosidade e a densidade de piaçavas por área são os fatores que mais dificultam o egresso de novas plantas de piaçava.

A prática de plantio tradicional da piaçava ainda utiliza o fogo para limpeza inicial, antes do plantio direto, por exemplo. Após o plantio da piaçava, o agroextrativista entra com o cultivo da mandioca, consegue plantar aproximadamente duas ou três safras de mandioca e em seguida deixa a área se desenvolvendo sem interferência antrópica e, com o passar do tempo, a piaçava começa a dominar a área, formando uma floresta de piaçava. Similar a essa técnica de plantio, outros relatos quilombolas apontaram para a retirada da mata secundária, com aproveitamento das madeiras maiores, limpeza com fogo e posterior plantio da mandioca. Em seguida, quando mandioca está madura, faz o plantio direto dos cocos de piaçava sem o epicarpo e o mesocarpo.

Considerando que o manejo tradicional da piaçava vem sendo realizado por índios, negros, caboclos e agroextrativistas da costa baiana, desde a colonização brasileira. E que o conhecimento acumulado e sistematizado sobre o extrativismo não madeireiro da piaçava ainda é escasso na literatura científica, não sendo encontradas publicações onde esses termos sejam elucidados, onde o saber tradicional seja evidenciado e destacado. Portanto faz-se necessário dedicar um espaço, no início do trabalho para definir e explicar termos e expressões utilizadas dentro do processo produtivo da fibra vegetal de piaçava. 


\subsection{1 - Termos Tradicionais do extrativismo da Piaçava da Bahia}

A 'tiragem da piaçava' refere-se ao ato de extração da fibra vegetal na palmeira da piaçava da Bahia, ou seja, a subida do extrativista na palmeira para retirada da fibra vegetal bruta. O 'tirador' é o extrativista especializado na subida em palmeiras, atividade genuinamente masculina, não tendo sido relatado em campo e nem na literatura, mulheres que a realizassem. A atividade requer força física e preparo físico da pessoa que executa essa etapa do manejo da fibra vegetal da piaçava.

Em seguida entra em cena outro profissional que dá o apoio e o suporte para o tirador de piaçava. Esse extrativista fica embaixo da palmeira para receber as fibras brutas extraídas, o 'tirador' tira 'capa' por 'capa' e joga-as no chão (Figura 10). O apoio junta as 'capas' de fibras formando as 'cabeças' de fibras brutas. Cada 'tirador' com seu auxiliar ficam responsáveis por uma área (talhão) que localmente se chama de 'eito'. Essa divisão da área entre os 'tiradores' é fundamental na organização da extração e mensuração da produção diária ou semanal de cada trabalhador envolvido. As 'cabeças' de fibras (conjunto de 'capas') de piaçava são arrastadas manualmente para as vias mais próximas do 'eito' e, nestes locais são formados os feixes ou 'mondongos' de fibra bruta com pesos entre 60 a $80 \mathrm{~kg}$ cada um. Essas fibras vegetais brutas são transportadas para os 'catadouros' ou vendidas para atravessadores in natura.

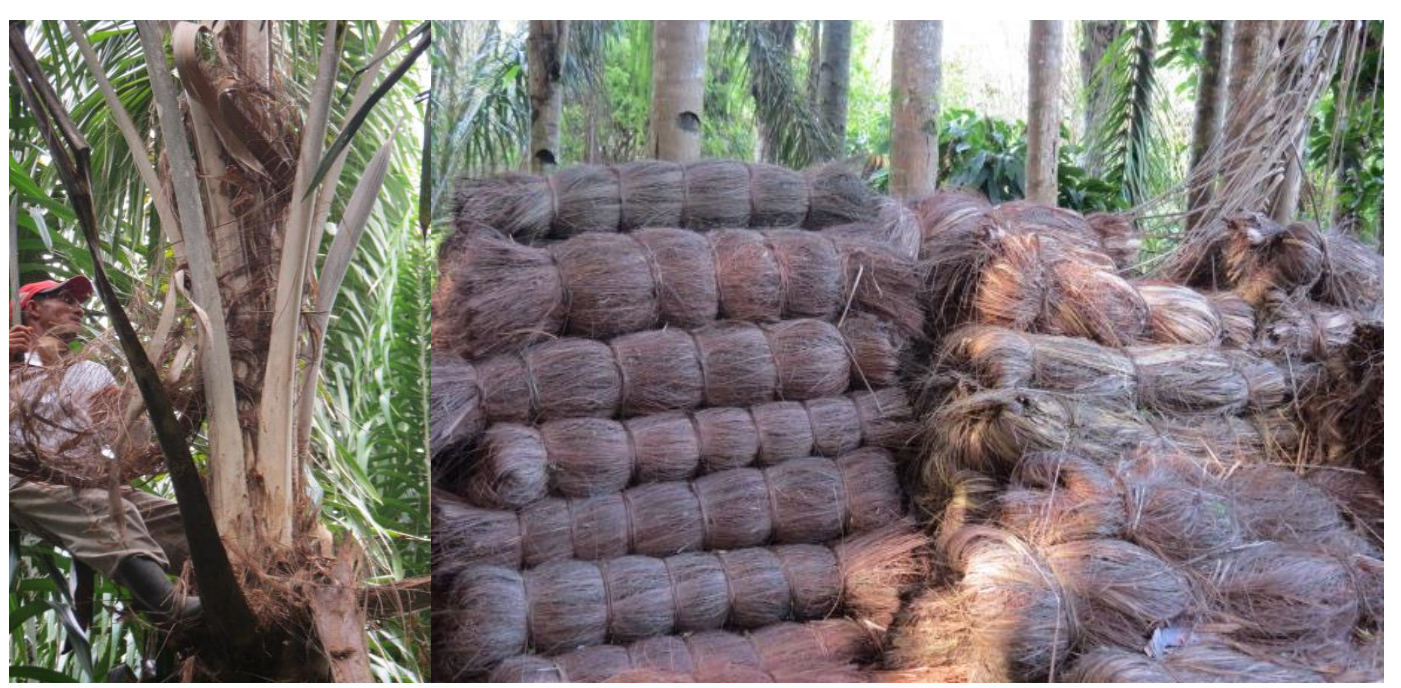

(a) (b)

Figura 10: 'Tiragem da fibra vegetal' (a) e os 'mondongos' de fibra limpa e fibra bruta, respectivamente, amarrados (b).

As fibras da piaçava estão localizadas na base do pecíolo de suas folhas. Nascem entre o pecíolo e o estipe da palmeira. As 'capas' são compostas por fibra vegetal e 'fitas'. 
As 'fitas são compostas pelo mesmo material vegetal das fibras, sendo não cilíndricas e mais achatadas. Essas 'fitas' são utilizadas na fabricação do 'pente de piaçava' e empregadas na cobertura de quiosques. As fibras e 'fitas' são recobertas por uma manta vegetal, denominada de 'capa', portanto, cada conjunto de fibra e fitas que nascem na base do pecíolo da planta, possui uma 'capa'. Portanto a 'capa' é a denominação dada para o manto vegetal que recobre a fibra bruta e a fita, produzida em cada folha, as 'capas' mais velhas estão localizadas entre o estipe e as folhas mais externas. As 'capas mais jovens estão mais ao centro da coroa da palmeira, parte mais interna, saindo do palmito da planta. A 'capa' de fibra e fita equivale à fibra bruta extraída da palmeira. Entre os índios Pataxó o termo 'cabeças de piaçava' é comumente usado, refere-se ao conjunto de 'capas' extraídas.

Os 'tocos' de fibra vegetal (Figura11) correspondem aos pedaços de 'capas' deixados entre a folha e o pecíolo, exatamente no local onde a 'capa' foi cortada pelo extrator. Esse toco só será aproveitado na próxima extração, quando esta folha já poderá ser podada e a 'capa' do 'toco' ficará amostra.

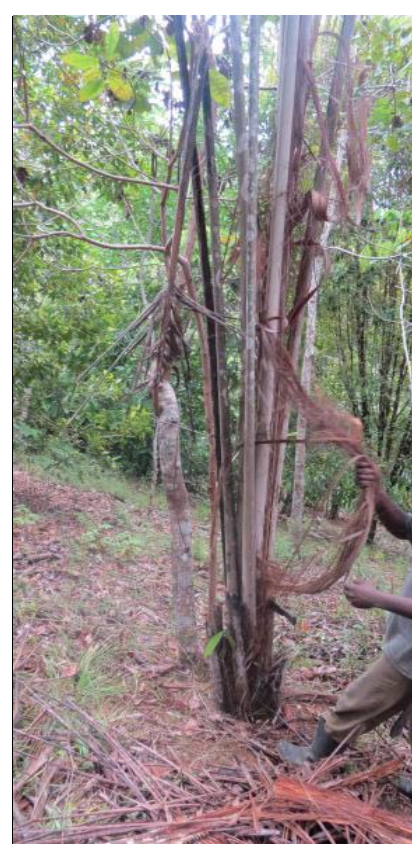

(a)

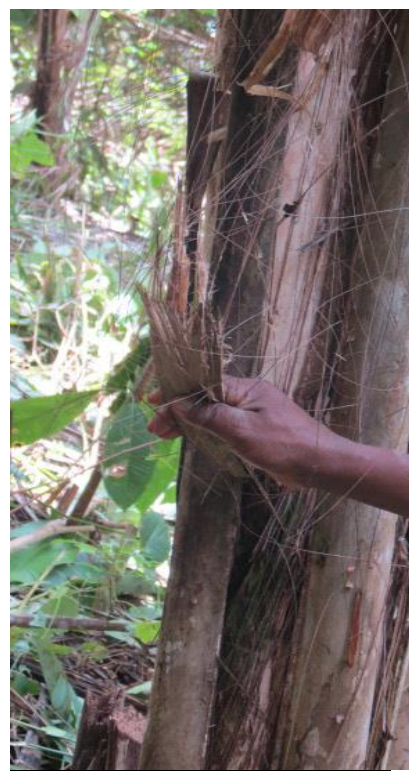

(b)

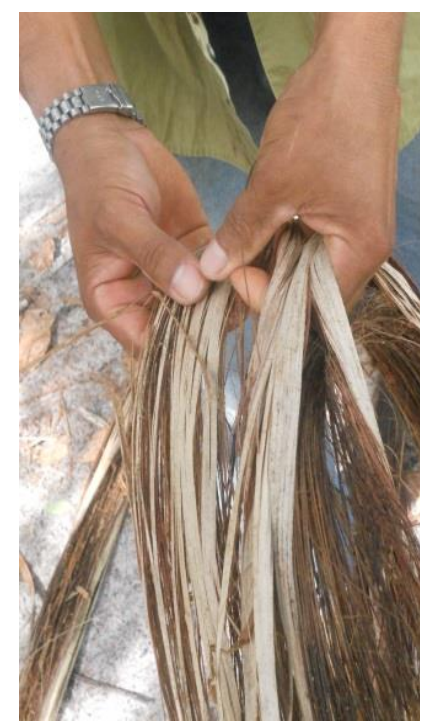

(c)

Figura 11: 'Tirador' puxando a 'capa' (a), detalhes do 'toco' ainda na planta (b) e detalhes da 'capa' de fibra bruta já extraída, onde a parte mais clara corresponde a 'fita' e a mais escura as fibras vegetais (c).

As folhas da palmeira nascem no centro da planta, no cálice foliar, onde está a parte mais tenra do estipe, ou seja, o palmito da palmeira. Popularmente conhecida como o 'olho' da palmeira. O crescimento das folhas ocorre de dentro para fora do cálice foliar, ou 
seja, o 'olho' da palmeira, meristema apical, tem sempre uma folha nova fechada em desenvolvimento. As extrativistas que trabalham com as folhas da piaçava mirim, no norte do Estado da Bahia, extraem exatamente as folhas fechadas, ou seja, folhas com seus folíolos ainda fechados. Essas folhas são flácidas e de fácil manuseio, são abertas pelas extrativistas após cozimento e tingimento. A retirada da folha nova e fechada, deixa amostra broto ou folha em desenvolvimento, ainda mais nova do que a folha fechada aparente. Nesse sentido é salutar observar que a contagem de folhas realizadas neste estudo, não considerou a presença dos brotos, pois ele não está visível. Então o número de folhas refere-se aquelas visíveis mais a folha nova fechada.

As folhas mais externas da circunferência do cálice foliar são mais maduras e necessariamente possui uma 'capa' de fibra e fita se desenvolvendo entre os pecíolos e o estipe e entre pecíolos das folhas no cálice foliar. Folhas fechadas ou muito jovens não possuem 'capas' de fibra e fita aparentes, assim como as mudas até a fase inicial de bananeiras novas, quando as primeiras 'capas' ficam aparentes.

Conforme este levantamento a piaçava na fase de muda (patioba) apresentaram em média de 3,22 folhas por muda, entre as 50 mudas encontradas nas 11 parcelas avaliadas. Com o desenvolvimento da palmeira, as folhas vão crescendo e o seu pecíolo vai se tornando mais resistente, denso e longo, formando o tronco da palmeira até o aparecimento do estipe. Na fase bananeira nova encontrou-se em média 3,71 folhas por planta, entre as 59 bananeiras novas encontradas nas 11 parcelas avaliadas. As plantas na fase de bananeira em produção apresentaram em média 6,72 folhas por planta, entre os 202 indivíduos analisados. Na fase coqueiro encontrou-se uma média de 10 folhas por palmeira, entre as 156 plantas coqueiros encontradas nas 11 parcelas (Figura 12). 


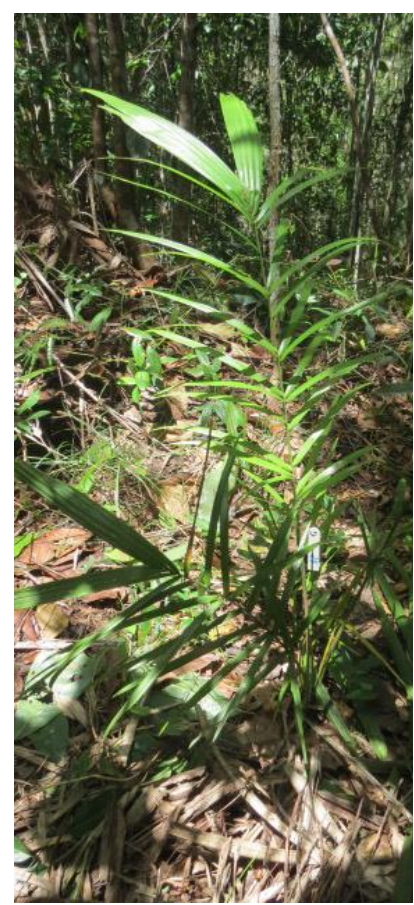

(a)

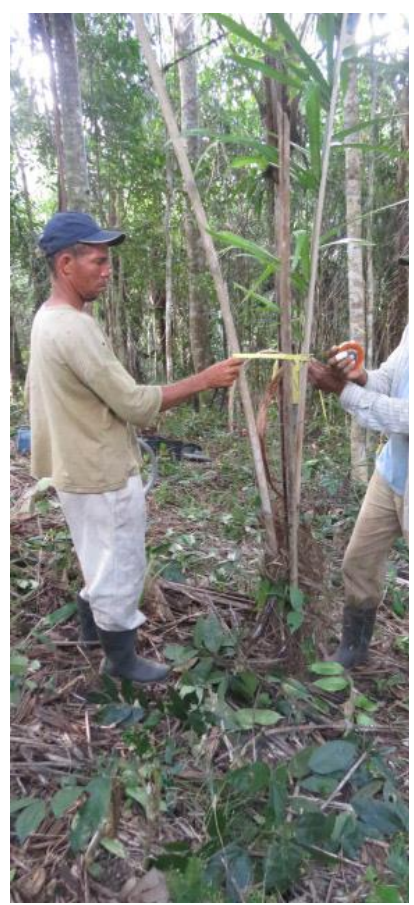

(b)

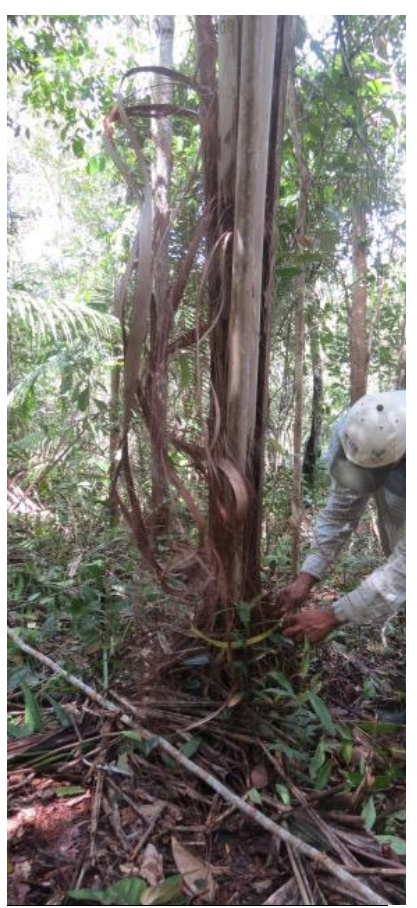

(c)

Figura 12: Palmeira de piaçava muda ou patioba (a), bananeira nova (b) e bananeira em produção com a 'capa' de fibra bruta (c).

Observou-se um acréscimo no número de folhas conforme o desenvolvimento da planta, e consequentemente ocorre à produção de fibras, ou seja, o desenvolvimento das 'capas' (fibras vegetais e 'fitas'). Na fase muda (patioba) não é possível notar uma 'capa' de fibra, fato que já é possível observar na fase bananeira nova, em diante. Na fase bananeira nova não se deve fazer a extração da fibra, pois a planta está muito tenra e a retirada da 'capa' de fibra e fita pode condenar o desenvolvimento natural da planta. $\mathrm{Na}$ fase bananeira em produção a planta tem mais de uma 'capa', os pecíolos estão mais desenvolvidos, a planta está com mais estabilidade e, portanto a extração das fibras e fitas já pode ser iniciada. Sem a retirada das folhas, somentes das fibras.

Os 'tiradores' experientes visualizam quantas 'capas' a planta possui e definem quantas poderão ser retiradas, ainda embaixo da palmeira. Depois de atingir o cálice foliar, durante a extração das 'capas', normalmente o 'tirador' verifica que o número de 'capas' é superior aquele previsto ainda em solo. Isso é devido à forma de crescimento das 'capas', sempre bem fixada aos pecíolos e estipe da planta, a fibra bruta cresce em espiral recobrindo os pecíolos e estipe da planta.

A fibra vegetal bruta também é denominada de 'cajibá' pelas extrativistas, descendentes dos Índios Tupinambá, localizadas na comunidade de Massarandupió, Município de Entre Rios, norte da Bahia. A variedade de piaçava mirim corresponde à 
piaçava acaule, produz pouca fibra bruta ('cajibá) e, não é explorada comercialmente nessa região. As extrativistas aproveitam a folha nova e fechada da palmeira. Os folíolos são denominados de 'palha' e a folha de 'palma', o pecíolo é o 'tandú' do qual se tira pequenas tiras para fazer artesanatos. Essas tiras retiradas do pecíolo são denominadas de 'quitanda'.

A 'cata da piaçava' é a atividade de separação da fibra e 'fita', ou seja, a limpeza da 'capa', essa manta vegetal que envolve a fibra da piaçava. O pré-beneficiamento pode ser realizado próximo às áreas de extração, fato observado na região de Canavieiras, onde agricultores familiares e outros descendentes de negros trabalham como 'meeiros' nas matas e plantios de piaçava, a separação ou 'cata' manual das fibras é feita com 'pentes metálicos', conforme ilustra a Figura 13. Esses 'pentes metálicos' também são feitos com madeira, prego e fixados em um suporte de madeira. Outra prática extrativista é o transporte dos feixes das fibras brutas ou 'capas' para os 'catadouros familiares'. Nestes locais as mulheres fazem a separação da fibra e 'fita' realizada com o equipamento 'escova', no formato de uma palmatória, esse equipamento tradicional consiste numa haste de madeira com pregos grandes, Figura 13, observados principalmente na região de Ituberá e Nilo Peçanha, municípios de grande concentração de quilombolas.

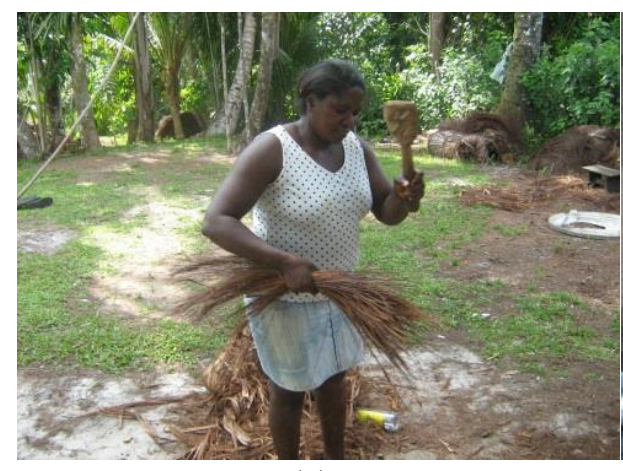

(a)

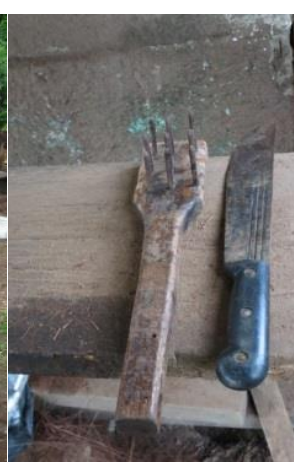

(b)

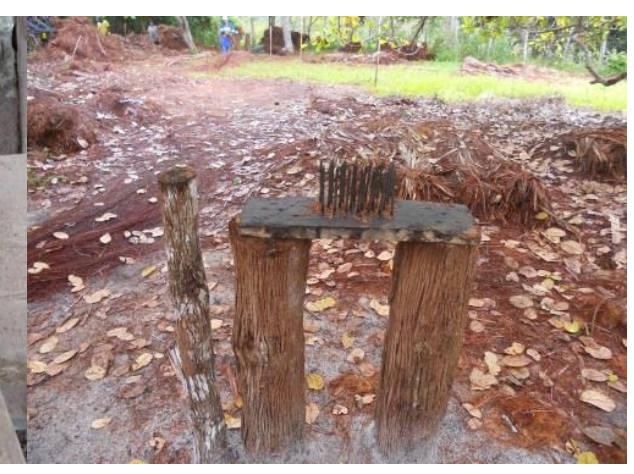

(c)

Figura 13: Mulher realizando a 'cata' da fibra da piaçava (a), equipamentos utilizadas 'escovas' e facão (b), pentes metálicos (c).

O termo 'borra' ou 'bagaço' é utilizado para designar a 'fita' de piaçava, que é o subproduto oriundo da limpeza da fibra vegetal. Ressalta-se que os próprios extrativistas e a literatura disponível utilizam os três termos para se referir a esse mesmo material vegetal. Em algumas falas dos atores locais envolvidos na cadeia da piaçava da Bahia observou-se que o termo 'bagaço' também é usado para referir se às fibras sem valor comercial, resíduos resultantes do processamento da fibra vegetal nas fábricas de vassouras.

Entre os agroextrativistas da Costa do Cacau (produtor) a 'fita' também é denominada de 'borra' ou 'bagaço', um subproduto da etapa de pré-beneficiamento da 
fibra vegetal. Os agroextrativistas da Costa do Dendê, especificamente os quilombolas, utilizam o termo 'borra' para se referirem aos resíduos de processamento formado ao longo das etapas produtivas.

A 'fita' é o material utilizado para confeccionar os 'pentes de piaçava'. Esses 'pentes' são utilizados para cobertura dos quiosques de praia e, são compostos por uma ripa de madeira onde a 'fita' é amarrada em pequenos maços, Figura 14.

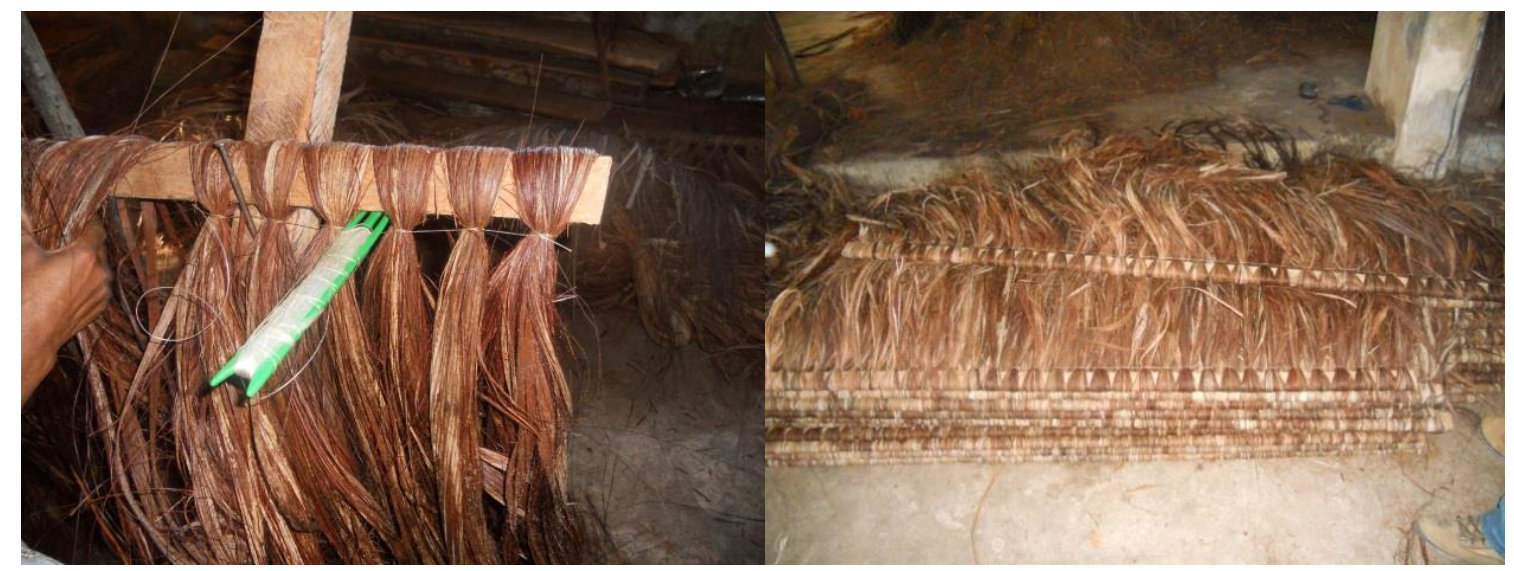

Figura 14: Pentes para cobertura, feitos com 'fita', subproduto da etapa de 'cata'. Utilizado para cobertura de quiosques de praia.

Também são denominados de 'pentes' o equipamento para limpeza da fibra vegetal, conforme Figura 14, acima. Neste estudo quando referirmos à 'pente da piaçava' estaremos considerando o material vegetal 'fita' utilizado para cobertura de quiosques. Para referirmos ao equipamento de limpeza da fibra adotou-se 'pentes metálicos'.

O termo 'pasmado' é usado para designar palmeiras que estão em processo de morte devido a danos físicos e/ou ataques de pragas e doenças, Figura 15. Nesta situação, a palmeira ainda está viva, mas, dá sinais de que não conseguirá manter sua produtividade por muito tempo, tanto relacionado à produção de fibra quanto a produção de frutos. Alguns sinais da palmeira 'pasmada' são: ausência de folhas jovens e fechadas, folhas brotando do 'olho' da palmeira; mais folhas secas do que verdes na planta; estipe oco e inclinado e, poucas folhas, 'capas' e 'tocos'. 


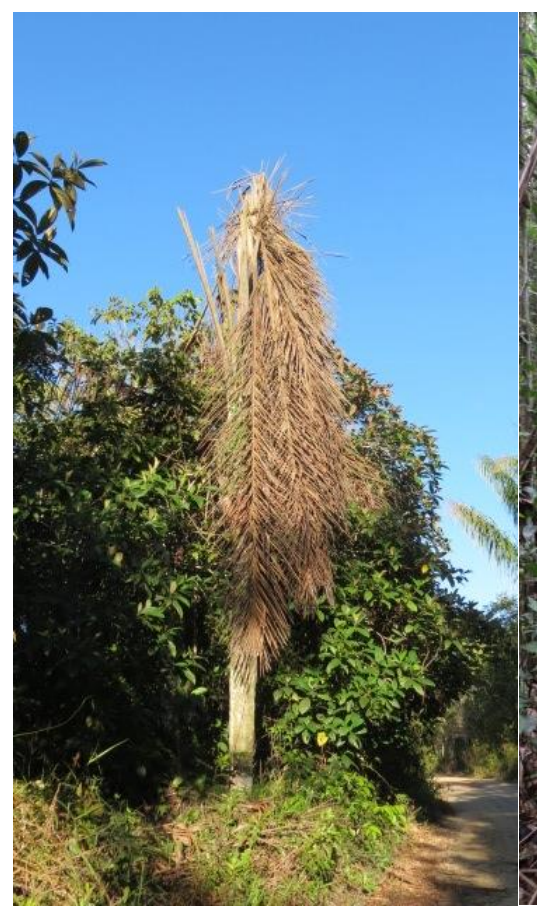

(a)

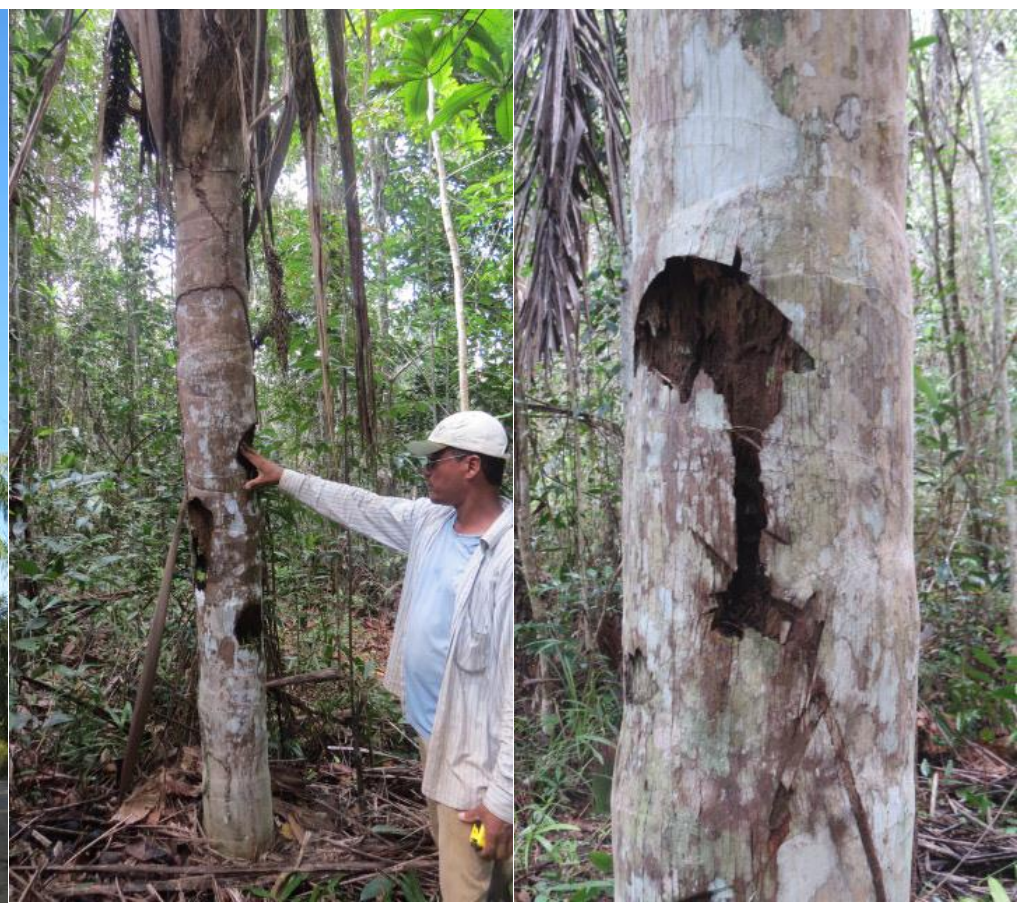

(b) (c)

Figura 15: Piaçavas danificadas: (a) palmeira morta por danos no 'olho'; (b) danos no estipe da palmeira 'pasmada' e detalhe da incisão feita no estipe da palmeira (c).

Os danos provocados no 'olho' da palmeira são irreversíveis e, portanto causam a morte da piaçava. Esses danos são decorrentes da extração das 'capas' de folhas novas, queda de folhas maduras sob o meristema apical da palmeira e técnicas de extração da folha que atinjam a nova folha do 'olho' da piaçava mirim (piaçava acaule).

\subsection{2 - Técnicas e Tecnologias de Extração da Fibra Vegetal}

A extração das fibras de piaçava é a principal atividade relacionada à etapa de manejo florestal da espécie, seja em áreas de ocorrência natural da espécie, em capoeiras, áreas enriquecidas com a palmeira ou em florestas cultivadas, a extração das fibras vegetal é manual e realizada por extrativistas especialistas. As técnicas e tecnologias adotadas para manejo desses povoamentos de piaçava sofreram poucas modificações ao longo dos anos e, são bastante semelhantes nos diversos municípios baianos onde ocorre a espécie. Como já mencionado a 'tiragem' da piaçava é o termo tradicional utilizado para se referir à etapa de extração da fibra, ou seja, o ato de subida na palmeira para a extração da fibra. $\mathrm{O}$ extrativista é conhecido como 'tirador' da fibra bruta ${ }^{14}$ da piaçava. A extração da fibra em

\footnotetext{
${ }^{14}$ Fibra bruta deve ser entendida como o conjunto de fibra suja mais a fita, esse conjunto forma a 'capa'.
} 
palmeiras de pequeno porte, bananeira em produção e coqueiro recém-formado, é realizada sem a necessidade de subida nas palmeiras. Já a extração em palmeiras com estipe superior a $2 \mathrm{~m}$ é necessário técnicas de escalada para acessar as fibras na palmeira, essas técnicas possuem características peculiares em cada área amostrada.

A extração da fibra bruta da piaçava é a atividade que oferece maior risco a saúde e segurança do trabalhador, devido à altura das palmeiras e a presença de animais peçonhentos no cálice da palmeira.

Considerando a totalidade das plantas que sofreram extração nas duas áreas, ou seja, 42 plantas, o tempo médio mensurado para subida e extração da fibra bruta das 42 plantas avaliadas neste trabalho foi de 11,6 minutos. O tempo médio para extração das 22 plantas no estagio de crescimento bananeira em produção (BP) foi de 6 minutos cada. $\mathrm{O}$ tempo médio para subida e extração em 20 coqueiros (COQ) foi de 16,3 minutos cada. A média e os coeficientes de variação são apresentados na Tabela 08. Observe que o coeficiente de variação do tempo de subida e extração das fibras foi o menor nos COQ quando comparado com a totalidade das plantas analisadas e a extração na fase BP, mesmo avaliando um número menor de plantas (20 plantas) na fase COQ.

Tabela 08: Tempo médio (minutos) de subida e extração da fibra bruta das 42 plantas mensuradas nas 11 parcelas amostradas neste estudo.

\begin{tabular}{lccc}
\hline \multicolumn{1}{c}{ Medidas } & $\begin{array}{c}\text { Total de Plantas } \\
\text { (42 plantas) }\end{array}$ & $\begin{array}{c}\text { BP } \\
\text { (22 plantas) }\end{array}$ & $\begin{array}{c}\text { COQ } \\
\text { (20 plantas) }\end{array}$ \\
\hline Média Tempo (min) & 11,6 & 6 & 16,3 \\
C.V $(\%)$ & 74,1 & 50,4 & 47,6 \\
Tempo Máx. (min) & 33 & 11 & 32 \\
Tempo Mínimo (min) & 3 & 3 & 6 \\
\hline
\end{tabular}

Como não há necessidade de escalada na palmeira na fase de desenvolvimento BP e a planta tem uma menor massa de fibra vegetal (menor número de 'capas'), o tempo de extração é bem inferior às plantas na fase COQ. Características como: altura da palmeia; número de folhas; presença de epífitas; sazonalidade da extração; condições fitossanitárias da planta; quantidade de 'capas' aptas para extração; habilidade do 'tirador'; presença ou ausência de cachos de frutos e animais peçonhentos.

Com relação ao número de 'capas' por planta, as palmeiras amostradas nas duas áreas estudadas apresentaram em média 3,2 'capas' por planta, com comprimento médio de 3,9 metros. Na fase COQ, as 20 palmeiras apresentaram, em média 4,7 'capas' por planta, com comprimento médio de 3,3 metros, com variação de 2,4 a 4,6 metros. As palmeiras na 
fase BP apresentaram em média 2 'capas' por planta, com comprimento médio de 3,3 metros. Nesta caso as plantas BP apresentaram uma variação entre 0,4 metros e 5,25 metros de comprimento, entre as 22 plantas na fase BP analisadas (Tabela 09).

Tabela 09: Número e comprimento de 'capas' por planta e por fase de desenvolvimento da piaçava.

\begin{tabular}{ccccc}
\hline Medidas & Total de Plantas & $\mathrm{BP}^{16}$ & $\mathrm{COQ}^{17}$ & Toco $^{18}$ \\
\hline Número de Capas/Planta & & & & \\
Média & 3,26 & 2 & 4,7 & 1,6 \\
CV (\%) & 66,36 & 59,8 & 46,4 & 59,8 \\
Máximo & 10 & 5 & 10 & 4 \\
Mínimo & 1 & 1 & 1 & 1 \\
Média (m) & & & & \\
CV (\%) & 3,29 & 3,3 & 3,3 & 0,7 \\
Máximo & 28,15 & 35,2 & 18,4 & 33,3 \\
Mínimo & 5,25 & 5,25 & 4,6 & 1,3 \\
Comprimento da Fibra (m) & 0,4 & 0,4 & 2,37 & 0,6 \\
\hline
\end{tabular}

Do total de palmeiras amostradas nas duas áreas estudadas, 24 palmeiras (BP e COQ) apresentaram 'toco' no momento da extração e, considerando esse conjunto, foi encontrado em média um número de 1,6 'capas’ por planta, conforme Tabela 09.

A ausência de 'toco' em uma palmeira pode ser decorrente das primeiras extrações de fibra, como também pode ser devido a praticas de extração que não foram bem feitas, não sendo deixada uma pequena parte da 'capa' fixada entre a folha e o pecíolo da palmeira. Entre as plantas analisadas nas duas áreas, 57\% apresentaram toco e, destas, ‘58,3\% eram coqueiros (COQ) e 41,7\% eram bananeira em produção (BP).

\subsubsection{1 - Extração Indígena da Fibra Bruta de Piaçava}

Um estudo realizado por Gama et al. (2009), sobre manejo comunitário na Reserva Indígena da Jaqueira (Povo Pataxó), Município de Porto Seguro/BA, indica que durante a colheita de fibras de piaçava devem ser retiradas 3 a 4 folhas (talas), no máximo, por planta. Segundo esses autores, não se deve cortar cachos verdes (busas) e nem os troncos de piaçava. Propõem a rotação de talhões para a extração das fibras de piaçava. Os talhões devem ser ordenados de forma crescente e a rotação deve ser planejada dentro de um ano.

\footnotetext{
15 Total de plantas mensuradas neste estudo foi 42 ;

16 Total de plantas na fase bananeira em produção (BP) mensuradas neste estudo foi 22 ;

${ }^{17}$ Total de plantas na fase coqueiro (COQ) mensuradas neste estudo foi 20 ;

18 Total de plantas com a presença do 'toco' no momento da extração foram 24 .
} 
Assim, haverá um intervalo maior para voltar ao primeiro talhão que teve a extração de fibras.

A extração das fibras feita pelos Índios Pataxó (GAMA et al., 2009) consiste na avaliação da altura do estipe, se for até 3 metros, não é necessário a escora, se for entre 3 e 5 metros, será necessário a escora, ou seja, um apoio feito com madeira, que permite ao piaçaveiro subir na planta. Algumas plantas próximas à palmeira e de fácil escalada, podem ser utilizadas como escora. Já em cima da palmeira o 'tirador' corta uma tala ou pecíolo da folha e se instala nela, se apoiando de forma a ter as mãos livres. Assim inicia a extração das fibras vegetais brutas, retira-se os tocos (resto de fibras da exploração anterior) de pouco comprimento, em seguida corta outra tala com a 'capa' (fibra comercial) que é puxada e cortada com o facão em sua base, jogando-a no chão, próximo da planta. A recomendação é extrair no máximo 3 a 4 talas (capas) por planta em cada ciclo de extração.

As 'capas' são amarradas em fardos, em seguida são levados a algum corpo hídrico, onde ficam submersas de três a quatro dias. Essa etapa do manejo visa à limpeza da fibra, hidratação e melhoria da sua maleabilidade da mesma e recuperação de sua cor original avermelhada, que se perde em consequência da exposição da planta ao sol. Após o período de hidratação, os fardos da fibra ficam secando à sombra, por no mínimo 24 horas para facilitar o manuseio e permitir a verificação do peso da mesma. Após a secagem, os fardos são levados até o galpão de beneficiamento para serem penteados.

Neste manejo da piaçava pelos Índios Pataxó as principais dificuldades apontadas na extração das fibras são: subir na palmeira e transportar a fibra do local de extração até onde ocorre o pré-beneficiamento. Com relação ao transporte a dificuldade está em arrastar as 'cabeças de piaçava' ou conjunto de 'capas' emaranhadas no interior da mata, pois as 'capas' vão se prendendo nas árvores e tocos pelo caminho. Estima-se a perda de cerca de duas arrobas por área colhida, deixando um "caminho de piaçava onde ocorre o arraste das cabeças". A utilização de um animal para transportar as cabeças do ramal até o local de beneficiamento já facilitaria o trabalho, porém para o transporte dentro da mata até o ramal, os índios não conhecem alternativas. Outra dificuldade apontada durante a extração está relacionada ao risco de acidentes com cobras, aranhas, escorpiões (amarelo e preto) e lacraias, sendo os dois últimos mais frequentes (GAMA at al., 2009).

\subsubsection{1 - Extração quilombola da fibra bruta de piaçava}


Os quilombolas da Costa do Dendê, principalmente nos municípios de Nilo Peçanha e Ituberá, utilizam a técnica de subida em palmeiras de grande porte, coqueiro alto, através da realização de pequenas incisões no estipe da palmeira. Essas incisões são talhos feitos com facão pelo próprio extrativista e utilizados para apoiar o 'tirador' durante a sua subida, até atingir as primeiras folhas da palmeira. Os cortes são feitos girando em torno do tronco da palmeira, uma espécie de escada em espiral (Figura 16). Evitando-se assim o anelamento da planta.

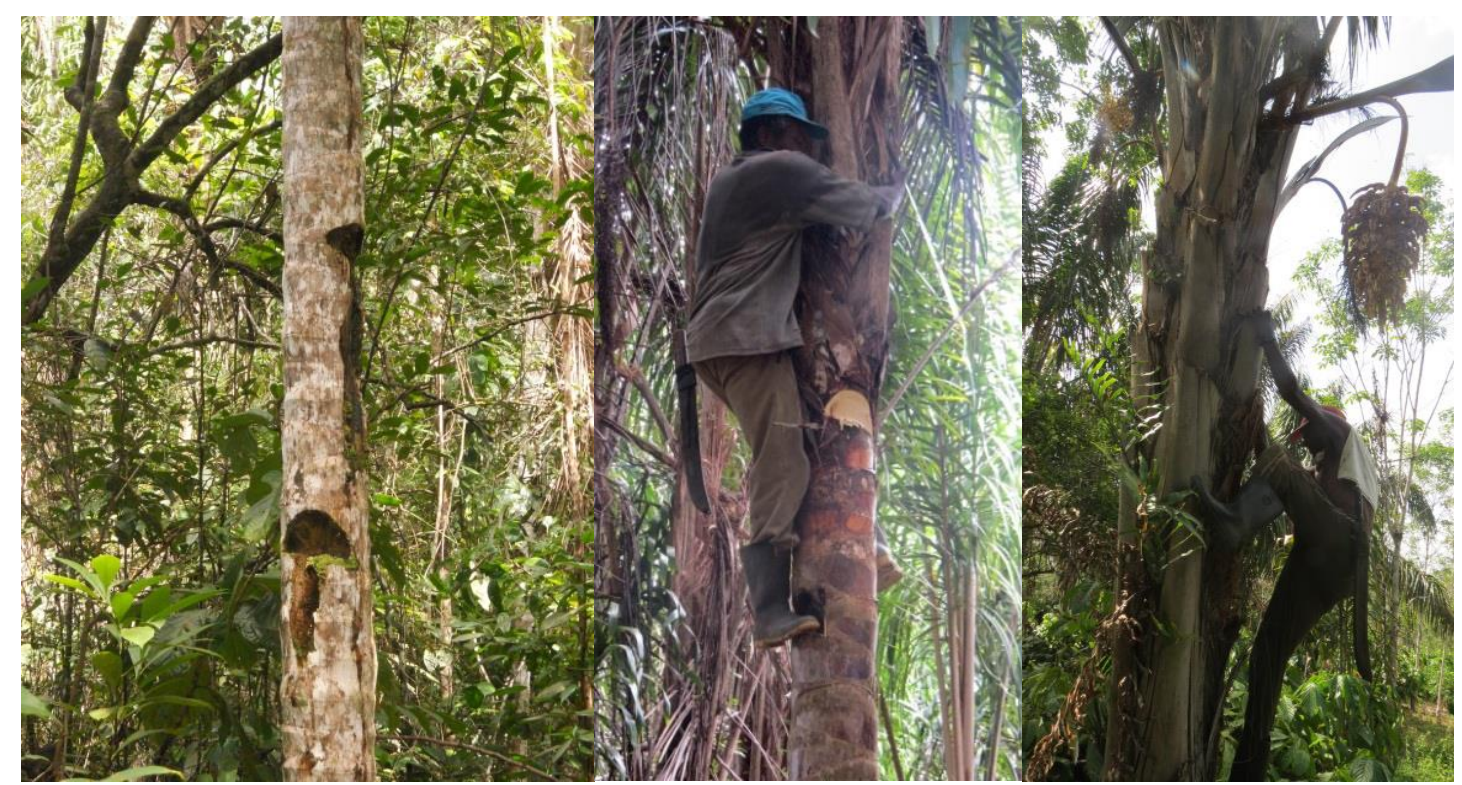

Figura 16: Incisões feitas com facão no estipe da palmeira em Ituberá, Bahia.

Quando o extrator alcança a parte superior da palmeira ele quebra uma 'tala' (pecíolo) das folhas externas, senta na mesma e inicia o despregamento das 'capas', ou seja, com a ajuda de um facão retira a fibra bruta e a fita. $\mathrm{O}$ 'tirador' circula o cálice foliar da palmeira passando o facão entre o estipe e o pecíolo, na parte interna da 'capa', no sentido vertical, de baixo para cima. Retorna a base da folha onde a 'capa' iniciou seu crescimento e faz um corte horizontal, de dentro para fora, deixando um 'toco' e evitando danos ao estipe em formação ou às folhas vizinhas. Nas situações em que o 'tirador' não conhece as técnicas tradicionais de extração e, realiza o corte de fora pra dentro da folha, ele acabará cortando o pecíolo da folha, extraindo necessariamente a folha.

A quantidade de folhas e 'capas' extraídas de cada planta depende da quantidade de folhas existentes e da sanidade da planta. Em cada extração retiram-se menos folhas que 'capas' por planta. 
A extração da fibra bruta também ocorre em folhas verdes que se mantém no pé após a extração, e isto favorece o desenvolvimento da planta, bem como, sua resistência ao tombamento. No manejo tradicional, essa poda é muito criteriosa, sendo retiradas as folhas secas com o 'toco' da última extração e, uma ou duas folhas verdes, localizadas na parte mais externas do cálice superior da palmeira na fase COQ. No caso da palmeira bananeira em produção (BP) as folhas verdes não são retiradas no momento da extração.

As incisões no estipe e a retirada de algumas folhas da palmeira são feitas de modo a conservar os cachos de frutos existentes no momento da extração, fato que requer mais habilidade do extrator. Durante os trabalhos de campo, observou-se que extratores inexperientes, ou simplesmente por ordem dos donos dos plantios, realizaram extrações danosas com intuito de matar as palmeiras devido à situação atual do mercado consumidor de fibra vegetal da piaçava.

O 'tirador' que realizou a extração das fibras brutas na área quilombo foi o Sr. Ivanildo Santos de Jesus. Foram mensuradas 22 plantas no quilombo, sendo 12 palmeiras na fase $\mathrm{BP}$ e mais 10 palmeiras na fase $\mathrm{COQ}$, com uma média geral de aproximadamente 12 minutos para subir e realizar a extração propriamente dita (Tabela 10).

Tabela 10: Tempo médio (minutos) de subida e extração da fibra bruta das plantas mensuradas nas 06 parcelas amostradas no Quilombo de Brejo Grande.

\begin{tabular}{lccc}
\hline \multicolumn{1}{c}{ Medidas } & $\begin{array}{c}\text { Total de Plantas } \\
(22 \text { plantas })\end{array}$ & $\begin{array}{c}\text { BP } \\
(12 \text { plantas })\end{array}$ & $\begin{array}{c}\text { COQ } \\
(10 \text { plantas })\end{array}$ \\
\hline Média Tempo (min) & 11,64 & 5,92 & 18,5 \\
C.V (\%) & 73,95 & 54,23 & 43,26 \\
Tempo Máx. (min) & 32 & 11 & 32 \\
Tempo Mínimo (min) & 3 & 3 & 9 \\
\hline
\end{tabular}

Conforme apresentado na Tabela 10, o tempo mínimo de extração de um coqueiro é de 9 minutos, enquanto que o tempo mínimo para se extrair as 'capas' de uma planta na fase de bananeira em produção não ultrapassou os três minutos. O coeficiente de variação das plantas BP e COQ, juntas, é bastante elevado cerca de $74 \%$, o maior valor quando comparamos com as plantas BP e COQ isoladamente.

A quantidade de 'capas' por planta e o número de folhas médio por planta e por fase de desenvolvimento é detalhado na Tabela 11. A quantidade de 'capas' maduras por planta corresponde ao número de 'capas' que poderá ser extraída. A estimativa do número de 'capas', feita pelos 'tiradores', antes da extração, embaixo da palmeira, revelou valores inferiores à quantidade de 'capa' apta à extração. Ou seja, observou-se o que o número de 'capas maduras', aptas a serem extraídas, foi superior ao mensurado embaixo do pé. Aqui é 
apresentado o número real de 'capas' aptas à extração, ou seja, a quantidade de 'capas' extraídas das 22 plantas.

O número de folhas médio foi avaliado em todas as plantas de cada parcela, nessa análise os resultados foram mensurados desconsiderando a presença de árvores mortas (sem folhas). Na Tabela 11 são apresentadas as médias das quantidades de folhas dos indivíduos produtivos das seis parcelas implantadas no Quilombo Brejo Grande. As análises do número de folhas somente dos 22 indivíduos de piaçava, selecionados para extração apresentou um elevado coeficiente de variação, por isso a opção pela análise de todas as plantas produtivas, levantadas em cada parcela.

Tabela 11: Número de 'capas' e número de folhas por planta e por fase produtiva de desenvolvimento da piaçava no Quilombo Brejo Grande de Ituberá

\begin{tabular}{cccc}
\hline Medidas & Total de Plantas & BP & COQ \\
\hline Número de Capas/Planta & & & \\
Média & 3,91 & 2,5 & 5,6 \\
CV (\%) & 59,03 & 55,27 & 36,89 \\
Máximo & 10 & 5 & 10 \\
Mínimo & 1 & 1 & 3 \\
Numero de folhas & & & \\
Média & 7,95 & 6,5 & 11,7 \\
CV (\%) & 18,78 & 12,32 & 9,17 \\
Máximo & 9,86 & 7,85 & 12,8 \\
Mínimo & 5,3 & 5,3 & 10,57 \\
\hline
\end{tabular}

O comprimento médio das 'capas' extraídas foi de aproximadamente 3,5 metros, tanto para as plantas na fase BP e COQ. Observa-se na Tabela 12 que o comprimento máximo das fibras na fase BP foi de 4,75 m que é superior a da fase COQ com 4,6 m, porém os valores mínimos na fase $\mathrm{BP}$ foram inferior ao da fase $\mathrm{COQ}$, demonstrando uma maior amplitude na variação do comprimento das fibras brutas extraídas das plantas BP. Valor que confirma o conhecimento tradicional e a literatura disponível, ambos afirmam que na fase de BP a piaçava produz fibras mais finas e longas e, na fase coqueiro elas também são longas, porém mais grossas.

Tabela 12: Comprimento de 'capas' por planta e por fase produtiva de desenvolvimento da piaçava no Quilombo Brejo Grande de Ituberá.

\begin{tabular}{cccc}
\hline Comprimento da Fibra (m) & Total de Plantas & BP & COQ \\
\hline & & & \\
Média (m) & 3,48 & 3,36 & 3,63 \\
CV (\%) & 24,93 & 31,4 & 16,03 \\
Máximo & 4,75 & 4,75 & 4,6 \\
Mínimo & 1,1 & 1,1 & 2,78 \\
\hline
\end{tabular}


Com relação ao comprimento de 'capas' a fase COQ apresentou o menor coeficiente de variação $16,03 \%$, demonstrando que as 'capas' exploradas variaram pouco entre si, principalmente quando comparada com a fase BP que obteve $31,40 \%$ de variação. A parcela 10 (plantio do Sr. Cosme) encontrou-se somente BP que sofreram a sua primeira extração e o comprimento médio das fibras nesta parcela foi de $1,58 \mathrm{~m}$, inferior à média do comprimento das 'capas' mensuradas no quilombo que apresentaram $3,36 \mathrm{~m}$ de comprimentos (Tabela 12). A parcela 11 apresentou um elevado número de plantas na fase de BP migrando para fase coqueiro, neste caso o comprimento médio dessas fibras vegetais foi de aproximadamente 4,16 m. Indicando que as plantas jovens, recém-chegadas na fase de desenvolvimento BP, ainda apresentam fibras de pequenos comprimentos, enquanto plantas saindo da fase BP apresentaram um comprimento maior.

\subsubsection{3 - Extração da fibra bruta pelo produtor local}

No Município de Canavieiras, os extrativistas utilizam outra técnica de subida nas palmeiras, sendo esta característica a principal diferença entre a extração da fibra bruta no quilombo e produtor rural. Neste caso, os extrativistas constroem uma vara de madeira leve (escora), de 7 a $12 \mathrm{~m}$, dependendo da altura da palmeira a ser explorada. A escora é colocada ao lado da palmeira e serve de apoio para o 'tirador' acessar a parte superior do coqueiro onde estão as folhas. A Figura 17 ilustra a extração da fibra bruta de piaçava com a utilização da técnica de subida com a escada de apoio. Essa técnica de subida evita as incisões no estipe das palmeiras COQ.

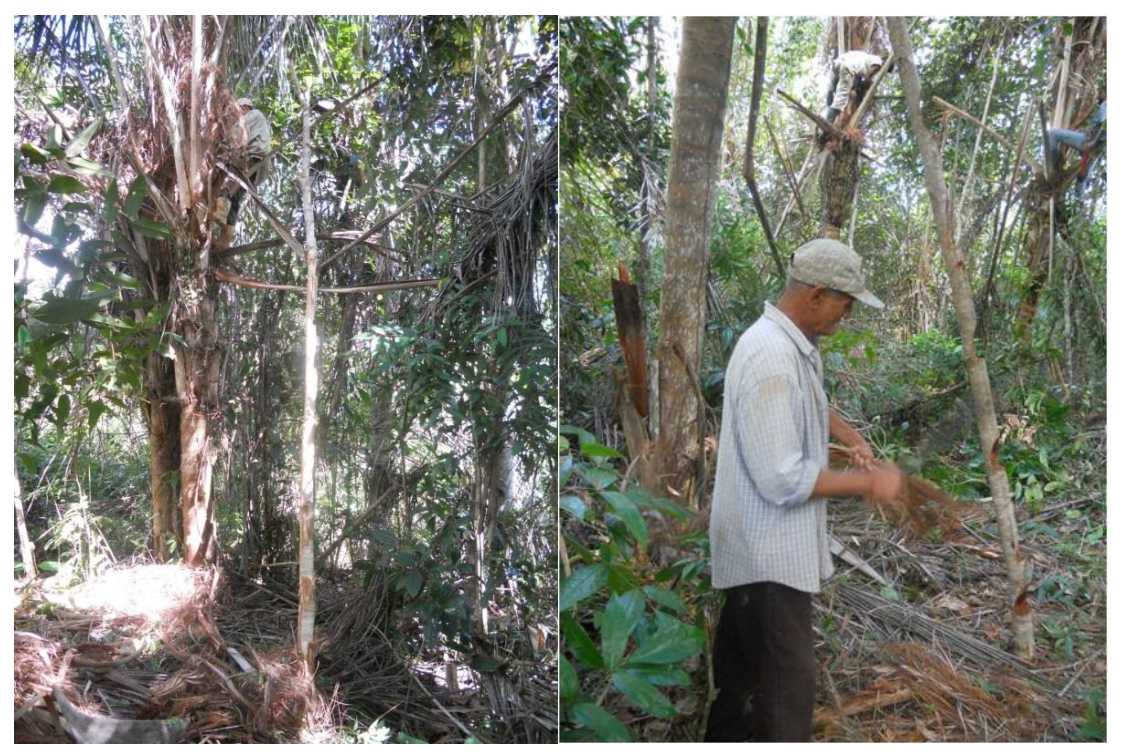

Figura 17: Extração com escoras de madeira em Canavieiras, Bahia. 
Os extratores que realizaram as extrações das fibras brutas na área particular foram o Sr. Jair Nascimento (Passarão) e o Sr. Arnoldo. Nesta área foram mensuradas 20 plantas produtivas, sendo 10 palmeiras na fase $\mathrm{BP}$ e mais 10 palmeiras na fase $\mathrm{COQ}$, com uma média geral $(\mathrm{BP}+\mathrm{COQ})$ de aproximadamente 11,6 minutos para subir e realizar a extração propriamente dita (Tabela 13). Observou-se que o tempo de extração da fibra bruta ('capa') no coqueiro foi aproximadamente em 17,1 minutos, superior ao tempo de extração nas plantas na fase de bananeira em produção onde o 'tirador' gastou 6,1 minutos por planta. $\mathrm{O}$ coeficiente de variação de 78,13\% para as plantas BP e COQ juntas é muito elevado, indicando aumento à necessidade de aumentar a amostra.

Tabela 13: Tempo médio (minutos) de subida e extração da fibra bruta das plantas mensuradas nas 05 parcelas amostradas na Propriedade Particular em Canavieiras.

\begin{tabular}{lccc}
\hline \multicolumn{1}{c}{ Medidas } & $\begin{array}{c}\text { Total de Plantas } \\
(20 \text { plantas })\end{array}$ & $\begin{array}{c}\text { BP } \\
(10 \text { plantas })\end{array}$ & $\begin{array}{c}\text { COQ } \\
(10 \text { plantas })\end{array}$ \\
\hline Média Tempo (min) & 11,6 & 6,1 & 17,1 \\
C.V (\%) & 78,13 & 47,92 & 57,79 \\
Tempo Máx. (min) & 33 & 11 & 33 \\
Tempo Mínimo (min) & 3 & 3 & 6 \\
\hline
\end{tabular}

A quantidade de 'capas' por planta e o número de folhas médio por planta e por fase de desenvolvimento é detalhado na Tabela 14. A média de 'capas' por planta na propriedade particular foi de 2,55 'capas'. No universo de 20 plantas que sofreram a extração, uma planta na fase COQ apresentou 7 'capas'.

O número de folhas médio foi avaliado em todas as plantas de cada parcela, neste caso cinco parcelas na propriedade, os resultados foram mensurados desconsiderando a presença de árvores mortas (sem folhas). Em média uma palmeira na fase de BP apresentou 5,5 folhas por planta e 10,2 folhas por planta na fase COQ. Na Tabela 14 são apresentadas as médias das quantidades de folhas dos indivíduos produtivos das cinco parcelas implantadas na propriedade particular. 
Tabela 14: Número de 'capas' e número de folhas por planta e por fase produtiva de desenvolvimento nas 05 parcelas implantadas na propriedade particular em Canavieiras.

\begin{tabular}{cccc}
\hline Medidas & Total de Plantas & BP & COQ \\
\hline Número de Capas/Planta & & & \\
Média & 2,55 & 1,4 & 3,7 \\
CV $(\%)$ & 70,24 & 36,89 & 51,04 \\
Máximo & 6 & 2 & 7 \\
Mínimo & 1 & 1 & 1 \\
Numero de folhas & & & \\
Média & 8,9 & 5,5 & 10,2 \\
CV (\%) & 4,7 & 14,2 & 14,7 \\
Máximo & 9,4 & 6,6 & 10,3 \\
Mínimo & 8,3 & 4,7 & 8,6 \\
\hline
\end{tabular}

O comprimento médio das 'capas', extraídas das 20 plantas na propriedade, foi de 3 metros, tanto para as plantas na fase $\mathrm{BP}$ e $\mathrm{COQ}$, quanto na fase $\mathrm{BP}$ isoladamente com comprimento de $3,23 \mathrm{~m}$. O comprimento das fibras na fase COQ foi aproximadamente 2,94 m, apresentando valores de comprimento máximos menores ao encontrados na fase BP, dados que confirmam o saber tradicional e Aquino (2013) que afirma que as fibras podem alcançar até 3,5 metros de comprimento.

Porém os valores mínimos de comprimento da 'capa' na fase BP foram inferior ao da fase COQ, demonstrando uma maior variação no comprimento das fibras brutas extraídas das piaçavas coqueiros. O coeficiente de variação da amostra de plantas na fase coqueiro foi $13,38 \%$ e $41,16 \%$ na fase bananeira (Tabela 15 ).

Tabela 15: Comprimento de 'capas' por planta e por fase produtiva de desenvolvimento da piaçava na Propriedade Particular em Canavieiras.

\begin{tabular}{cccc}
\hline Comprimento da Fibra $(\mathrm{m})$ & Total de Plantas & BP & COQ \\
\hline Média $(\mathrm{m})$ & 3 & 3,23 & 2,94 \\
CV $(\%)$ & 31,31 & 41,16 & 13,38 \\
Máximo & 5,25 & 5,25 & 3,65 \\
Mínimo & 0,4 & 0,4 & 2,4 \\
\hline
\end{tabular}

A comparação do tempo de extração do quilombo com a propriedade particular observa-se que na propriedade o tempo de extração foi menor do que o tempo de extração no quilombo, mesmo com estimativas de altura superior das plantas COQ e BP na propriedade, conforme Tabela 16. 
Tabela 16: Tempo médio de extração por parcelas e fase de desenvolvimento

\begin{tabular}{ccccc}
\hline \multirow{2}{*}{ Médias } & \multicolumn{2}{c}{ Quilombo } & \multicolumn{2}{c}{ Propriedade } \\
\cline { 2 - 5 } & COQ & BP & COQ & BP \\
\hline Tempo de Extração (min) & 18,5 & 5,92 & 17,1 & 6,1 \\
Média de Altura (m) & 10,98 & 8,92 & 13,47 & 9,65 \\
Médio de $\mathrm{n}^{\circ}$ de capas & 5,60 & 2,50 & 3,70 & 1,40 \\
Média de $\mathrm{n}^{\circ}$ de folhas & 11,70 & 6,50 & 10,30 & 5,50 \\
\hline
\end{tabular}

O número de capas por planta diminuiu, conforme diminuiu o numero de folhas e, também conforme a fase de desenvolvimento. Plantas na fase de BP tem um menor numero de folhas e 'capas' do que as plantas na fase COQ. O número médio de 'capas' das plantas no quilombo (BP +COQ) foi de 3,91 'capas' por planta, enquanto na propriedade foi de 2,55 'capas' por planta, indicando que as plantas do quilombo eram mais produtivas, elevando o tempo de extração de cada planta. Um dos fatores que influenciaram essa maior produtividade de 'capas' por planta foi intervalo entre as extrações das palmeiras, a última extração ocorreu entre 13 a 14 meses na propriedade e entre 24 a 48 messes nas parcelas do quilombo.

É importante acrescentar que na propriedade em Canavieiras e, também na região de Ituberá e Nilo Peçanha, a extração ocorre em grupo de dois extratores, o segundo homem fica embaixo da palmeira, juntando as 'capas' e 'tocos' extraídos. Conforme relato dos extrativistas da piaçava, um 'tirador' com seu ajudante, em uma hora de trabalho, conseguem fazer a limpeza da palmeira, extrair as 'capas' de aproximadamente uma arroba de fibra bruta, gerando uma produtividade diária de aproximadamente seis arrobas para ambos, segundo os extrativistas 'tiradores'.

Em algumas situações o 'tirador' prefere trabalhar sozinho, neste caso a técnica consiste em extrair as 'capas' de piaçava, joga-las no chão e seguir para outra palmeira, durante a primeira metade do dia (5 às 11 horas, por exemplo) e após o almoço o extrativista retorna às plantas, para recolher as 'capas' de piaçava, arrasta-las para via mais próxima e fazer os feixes de fibras brutas. Essa segunda técnica foi observada somente na região de Ituberá, com uma produtividade diária de aproximadamente $45 \mathrm{~kg}$ de piaçava bruta (ou três arrobas). Essa quantidade rende $30 \mathrm{~kg}$ de material limpo, segundo os extrativistas.

\subsection{3 - Precisão da amostragem realizada nas duas áreas com plantação de piaçava}

A precisão do inventário realizado nos plantios de piaçava nas duas áreas estudadas, considerou tanto a densidade de palmeiras quanto o número de folhas encontrado nas palmeiras, por hectare. 
Em termos de densidade de palmeiras, foi considerada a amostragem que incluiu as quatro fases de crescimento (Patioba - PB, Bananeira Nova - BN, Bananeira em Produção - BP e Coqueiro - COQ) e também a amostragem que incluiu apenas as palmeiras que permitem exploração para a produção de fibras (BP e COQ).

É importante salientar que em ambas as áreas estudadas (área particular e comunidade quilombola) houve plantio direto dos frutos de piaçava e, além disso, a condução do plantio não previu reposição de plantas. Portanto, como as duas áreas foram cultivadas, a presença da patioba e bananeira nova, demonstra que nessas áreas está ocorrendo a regeneração natural da espécie.

A Tabela 17 apresenta os resultados do inventário realizado nos dois plantios (área particular e quilombola), considerando a variável densidade de palmeiras.

Tabela 17: Resultado do inventário que avaliou a densidade de piaçavas ( $\mathrm{n}$ \% $/ \mathrm{ha}$ ) em duas plantações (área particular e quilombola), localizadas no Estado da Bahia.

\begin{tabular}{|c|c|c|c|c|}
\hline \multirow[t]{2}{*}{ Estimadores do Inventário } & \multicolumn{2}{|c|}{$\begin{array}{c}\text { Densidade } \\
(\mathrm{PB}+\mathrm{BN}+\mathrm{BP}+\mathrm{COQ})^{(1)}\end{array}$} & \multicolumn{2}{|c|}{ Densidade (BP+COQ) } \\
\hline & Área Particular & Quilombola & Área Particular & Quilombola \\
\hline Média (n⿳⺈⿴囗十) & 835 & 1.250 & 545 & 1.037 \\
\hline Variância & $20.812,5$ & $80.000,0$ & $69.187,5$ & $124.937,5$ \\
\hline $\begin{array}{l}\text { Coeficiente de Variação - CV } \\
(\%)\end{array}$ & 17,3 & 22,6 & 48,3 & 34,0 \\
\hline Erro Amostral $(\%)$ & 21,4 & 23,3 & 59,9 & 35,0 \\
\hline Intervalo de Confiança (nº $/ \mathrm{ha}$ ) & 656 a 1.014 & 959 a 1.540 & 218 a 872 & 674 a 1.401 \\
\hline
\end{tabular}

Observe na Tabela 17 que, quando se considerou todas as quatro fases de desenvolvimento da piaçava $(\mathrm{PB}+\mathrm{BN}+\mathrm{BP}+\mathrm{COQ})$, a precisão do inventário ou erro amostral do inventário ficou em torno de $21 \%$ para a área particular e $23 \%$ para a comunidade quilombola. Erros amostrais ou precisão acima de $10 \%$ são considerados altos em inventários florestais, e, para a redução dos erros, uma alternativa é aumentar a intensidade amostral. Contudo, para algumas condições em que a vegetação apresenta alta variabilidade nos dados da variável analisada, erros acima de $10 \%$ são bastante comuns, e, muitas vezes, mesmo aumentando a intensidade amostral, dificilmente consegue-se reduzir o erro amostral ou, em outras palavras, aumentar a precisão, já que a variabilidade dos dados analisados é intrínseca a condição da vegetação.

De acordo com o Manual Técnico da Vegetação Brasileira (IBGE, 2012), a expectativa do erro ao se estimar os parâmetros quantitativos em inventários de formações 
florestais e campestres, está em torno de $20 \%(\alpha=0,05)$ e, eventualmente, até um pouco mais.

No caso das plantações de piaçava estudadas, a variabilidade entre as amostras em termos de densidade foi alta, o que já era esperado, considerando que os plantios não foram submetidos a tratamentos silviculturais que propiciassem um desenvolvimento mais homogêneo das palmeiras. Além disso, todos os plantios possuem palmeiras em diferentes fases de desenvolvimento. Deve ser destacado também, que no caso específico da comunidade quilombola, a amostragem incluiu plantios de diferentes idades, devido aos critérios estabelecidos na pesquisa, o que pode também aumentar a variabilidade entre as amostras, no que se refere a variável analisada, ou seja, densidade. Portanto, os erros encontrados para as duas plantações podem ser aceitáveis.

Os resultados apresentados na Tabela 17 mostram que a densidade média de palmeiras de piaçava estimada para a plantação na área particular, cujas parcelas amostradas possuem, na sua maioria, cerca de 50 anos, é igual a 835 palmeiras/ha, média esta que pode variar na área entre 656 a 1.014 palmeiras/ha. Tal média é bem inferior à registrada na comunidade quilombola, ou seja, 1.250 palmeiras/ha, que pode variar de 959 a 1.540 palmeiras/ha, considerando, para ambos os casos um nível de significância $\alpha=5 \%$ $(\mathrm{p} \leq 0,05)$.

Tais resultados podem ser justificados pelo espaçamento de plantio adotado pelas comunidades. Embora, segundo informações coletadas em campo, os plantios das duas áreas utilizam espaçamentos $3 \times 3 \mathrm{~m}$ e $4 \times 4 \mathrm{~m}$, o que corresponde a, respectivamente, 1.111 e 625 palmeiras/ha, é importante destacar que a comunidade quilombola também utiliza uma medida empírica de espaçamento, ou seja, espaçamento feito "no olho". Isto, consequentemente, pode gerar grande variabilidade na densidade dos plantios, ficando alguns mais adensados que outros. As parcelas amostradas na comunidade quilombola apresentaram densidades que variaram de 825 a 1.525 palmeiras/ha $(\mathrm{CV}=22,63 \%)$. Tais valores refletem o uso de diferentes espaçamentos.

$\mathrm{Na}$ área particular, a variabilidade na densidade de palmeiras nas parcelas amostradas foi menor, variando de 625 a 975 palmeiras por hectare $(\mathrm{CV}=17,28 \%)$. Observe que tais valores estão próximos aos valores de densidade que correspondem aos espaçamentos $3 \times 3 \mathrm{~m} \mathrm{e} 4$ × $4 \mathrm{~m}$.

Silva; Vinha (1982) recomendam que a quantidade ideal de palmeiras por hectare deve estar em torno de 1.000 a 1.500 plantas, o que corresponde a um espaçamento igual a aproximadamente 3 × 3 m entre 'piaçaveiras'. 
Ao ser avaliado a densidade apenas das palmeiras produtivas, ou seja, que produzem fibras $(\mathrm{BP}+\mathrm{COQ})$, verificou-se (Tabela 18) que a amostragem realizada apresentou alta variabilidade, com $\mathrm{CV}=43,8 \%$ para a plantação em área particular e CV = $34 \%$ para plantação na comunidade quilombola. Consequentemente, o erro amostral também foi elevado, especialmente no caso da plantação em área particular $(59,9 \%)$. Essa baixa precisão da amostragem pode ser decorrente da pequena amostragem na área, ou da alta variabilidade nas condições ambientais dos plantios (nutrientes do solo, tipo de terreno, fator hídrico etc.), ou de alguma ação antrópica nos plantios (corte de palmeiras, fogo nas áreas, morte natural de palmeiras etc.), entre outros.

$\mathrm{Na}$ comunidade quilombola, o erro amostral foi igual a 35\%. Embora este erro também seja considerado alto, foi bem inferior que o obtido no inventário realizado na área particular. Este erro amostral alto no quilombo já era esperado, considerando que as parcelas apresentam idades diferentes de plantio. Os plantios mais velhos (30 a 50 anos) apresentaram maiores densidades de palmeiras produtivas (1.175 a 1.425 palmeiras/ha) e os plantios mais jovens ( 7 a 18 anos), as menores densidades (575 a 925 palmeiras/ha).

O inventário realizado nas duas áreas estimou que a densidade média de palmeiras produtivas na área particular é igual a 545, podendo variar de 218 a 872 plantas/ha. Esta densidade média de palmeiras produtivas também é bem inferior a média registrada na comunidade quilombola, isto é, 1.037, que pode variar de 674 a 1.401 plantas/ha, considerando um nível de significância $\alpha=5 \%(\mathrm{p} \leq 0,05)$.

Um estudo também realizado no Município de Canavieiras - BA (SILVA; GUIMARÃES, 2006) registrou em plantios de piaçava, 700 palmeiras/ha, pertencentes a diferentes fases de desenvolvimento. Destas, 620 plantas/ha eram produtivas. Os valores encontrados pelos autores estão próximos aos registrados neste estudo, a área particular, que também está localizada no Município de Canavieiras (Tabela 18).

Nas duas plantações de piaçava estudadas foi observado que a percentagem de palmeiras não se encontra em equilíbrio. No total, os plantios amostrados apresentaram maior percentual de palmeiras produtivas $(\mathrm{BP}+\mathrm{COQ})$ do que palmeiras em fase inicial de desenvolvimento $(\mathrm{PB}+\mathrm{BN})$. $\mathrm{Na}$ área particular, $65 \%$ das palmeiras encontram-se em fase produtiva e $35 \%$ encontram-se na fase inicial de desenvolvimento e, na comunidade quilombola, $83 \%$ encontram-se na fase produtiva e $17 \%$ na inicial.

A precisão do inventário também considerou o número de folhas nas palmeiras (Tabela 18), já que a produção de fibras de piaçava está diretamente relacionada com a 
produção de folhas abertas (SILVA; GUIMARÃES, 2006), verdes e secas de plantas saudáveis.

Tabela 18: Resultado do inventário que avaliou o número de folhas abertas verdes e secas (plantas saudáveis) em palmeiras produtivas (BP e COQ) de piaçavas ( $\mathrm{n} / \mathrm{o} a)$ em duas plantações (área particular e quilombola), localizadas no Estado da Bahia.

\begin{tabular}{|c|c|c|c|c|}
\hline \multirow[t]{2}{*}{ Estimadores do Inventário } & \multicolumn{2}{|c|}{$\begin{array}{l}\text { Folhas Abertas Verdes } \\
\qquad(\mathrm{BP}+\mathrm{COQ})^{(1)}\end{array}$} & \multicolumn{2}{|c|}{$\begin{array}{l}\text { Folhas Abertas Secas } \\
\text { (BP+COQ) }\end{array}$} \\
\hline & Área Particular & Quilombola & Área Particular & Quilombola \\
\hline Média (n⿳⺈/ha) & 4.100 & 7.466 & 1.015 & 2.545 \\
\hline Coeficiente de Variação - CV (\%) & 58,5 & 40,7 & 96,4 & 57,6 \\
\hline Erro Amostral (\%) & 72,6 & 41,8 & 120 & 59,3 \\
\hline
\end{tabular}

${ }^{(1)} \mathrm{BP}=$ Bananeira em Produção; e COQ = Coqueiro

De uma forma geral, a variabilidade obtida para número total de folhas abertas verdes e secas de plantas saudáveis nas palmeiras inventariadas nas unidades amostrais de cada área foi bastante elevada $(\mathrm{CV} \geq 40 \%)$, o que, consequentemente, não permitiu a obtenção de uma boa precisão do inventário realizado em ambas as áreas (Tabela 18). Por exemplo, na área particular, os erros amostrais atingem valores na ordem de 72\%, para estimativa de número de folhas abertas verdes por hectare e de $120 \%$ para número de folhas secas. No caso do inventário na comunidade quilombola, os erros amostrais foram menores, embora tais valores sejam também considerados muito altos.

Portanto, para as duas áreas estudadas, não foi possível gerar estimativas precisas de número de folhas de piaçava por hectare, considerando a intensidade de amostragem utilizada no inventário, pois em cada área de estudo, a intensidade de amostragem aplicada, proporcionou baixa precisão das estimativas. Uma alternativa para diminuir o erro amostral, ou, consequentemente, aumentar a precisão das estimativas nos dois inventários, seria aumentar a intensidade de amostragem.

Entretanto, o aumento da intensidade amostral nas duas áreas não garante o aumento da precisão dos dois inventários, pois a alta variabilidade encontrada nas duas áreas, em relação a número de folhas por unidade de área, pode estar relacionada ao próprio manejo que é realizado em cada área. Embora tenham sido analisadas apenas as palmeiras em fase produtiva $(\mathrm{BP}+\mathrm{COQ})$, as parcelas amostradas nos dois plantios apresentam diferentes idades (em especial na comunidade quilombola) e, além disso, a idade das palmeiras amostradas em cada parcela é muito variável, pois embora cada parcela tenha uma idade específica, correspondente a época da implantação do plantio, muitas palmeiras surgiram nas parcelas pós-plantio, seja por meio de germinação de sementes de palmeiras no local e posterior estabelecimento das novas palmeiras, ou por 
meio de introdução de mudas de piaçava ao longo do tempo. Consequentemente, esta heterogeneidade causa grande variabilidade na produção de folhas entre unidades amostrais (Figuras 18 e 19).

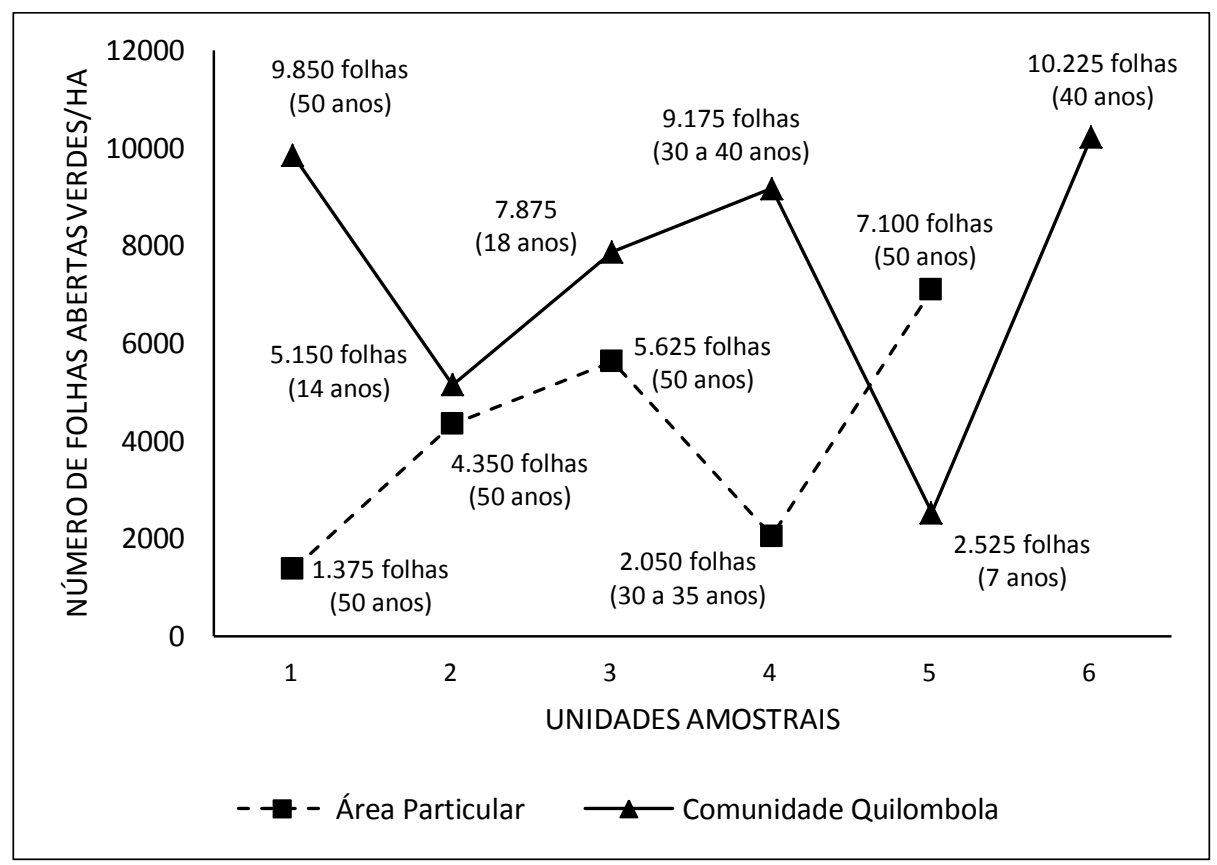

Figura 18: Número de folhas abertas verdes (plantas saudáveis) por hectare registradas em palmeiras produtivas (BP e COQ) de piaçavas em duas plantações (área particular e quilombola), localizadas no Estado da Bahia.

Contudo, independentemente da precisão dos inventários, os resultados mostram que o número médio de folhas abertas verdes e secas (plantas saudáveis) nas palmeiras de piaçava amostradas nas plantações da comunidade quilombola foi bem superior à registrada na plantação da área particular (Tabela 19), o que é justificável, considerando que os plantios da comunidade quilombola apresentam maior densidade de palmeiras produtivas $(\mathrm{BP}+\mathrm{COQ})$, com grande destaque para as palmeiras em produção, que apresentam maior quantidade de folhas abertas e verdes em relação aos coqueiros. Vale salientar que uma palmeira em produção investe grande parte dos seus recursos e da energia captada durante a fotossíntese, para a produção de folhas, ao passo que no coqueiro, grande parte dos recursos e da energia é alocada para a produção de flores e frutos, por isso, a quantidade de folhas é menor. 


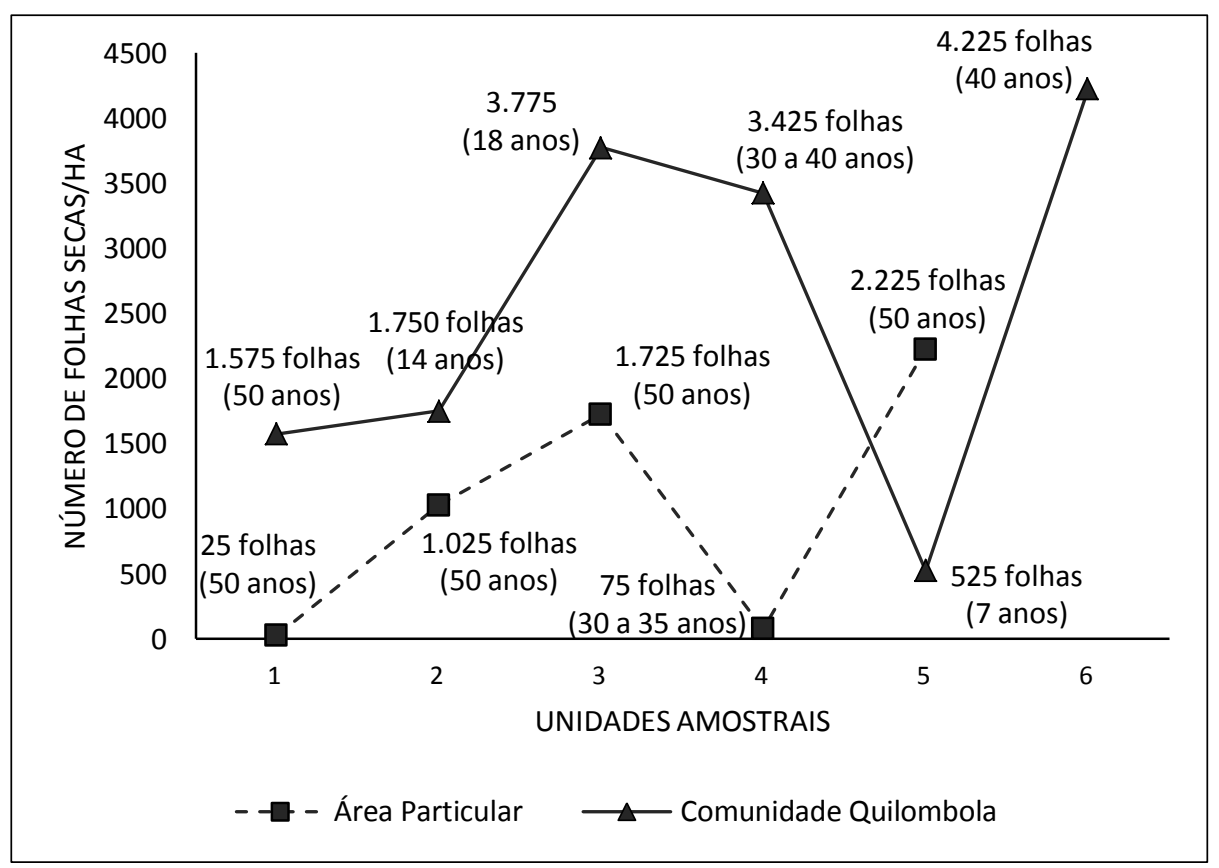

Figura 19: Número de folhas abertas secas (plantas saudáveis) por hectare registradas em palmeiras produtivas (BP e COQ) de piaçavas em duas plantações (área particular e quilombola), localizadas no Estado da Bahia

Mas, embora a produção de folhas de palmeiras produtivas $(\mathrm{BP}+\mathrm{COQ})$ tenha sido bem maior nos plantios da comunidade quilombola, o número médio de folhas abertas, tanto verdes quanto secas (plantas saudáveis), foi bastante similar nas duas áreas estudadas. Em média, para as duas áreas estudadas, uma palmeira produtiva apresenta cerca de 7 (sete) folhas abertas verdes e 2 (duas) folhas secas em plantas saudáveis.

\subsection{4 - Descrição estatística das variáveis relacionadas à produção da piaçava}

As Tabelas 19 a 22 apresentam as estatísticas descritivas das variáveis altura total estimada (HT), altura do estipe (HE), DB, DAP, número de folhas com 'capas' (NFC) e número de folhas com 'toco' (NFT), obtidas para palmeiras de piaçava em fase de produção (BP e COQ), amostradas tanto na propriedade particular, quanto na comunidade quilombola. Observe que, de uma maneira geral, todas as variáveis analisadas (HT, HE, DB, DAP, NFC e NFT), nas diferentes condições estudadas, apresentam alta heterogeneidade nos plantios, com coeficientes de variação acima de $30 \%$. 
TABELA 19: Estatística descritiva de palmeiras produtivas (BP) de piaçava amostradas na área particular, localizada no Município de Canavieiras, Bahia.

\begin{tabular}{lccccc}
\hline \multirow{2}{*}{ Estatísticas } & \multicolumn{5}{c}{ Variáveis } \\
\cline { 2 - 6 } & HT estimada $(\mathrm{m})$ & DB $(\mathrm{cm})$ & DAP $(\mathrm{cm})$ & NFC & NFT \\
\hline Média & 10,0 & 24,4 & 29,2 & 2,0 & 1,6 \\
Máximo & 14,0 & 35,0 & 57,3 & 4,0 & 4,0 \\
Mínimo & 6,0 & 12,7 & 18,5 & 1,0 & 1,0 \\
CV\% & 18,7 & 25,5 & 30,0 & 47,8 & 62,9 \\
IC & $10,0 \pm 1,9$ & $24,4 \pm 6,2$ & $29,2 \pm 8,7$ & $2,0 \pm 1,0$ & $1,6 \pm 1,0$ \\
\hline
\end{tabular}

TABELA 20: Estatística descritiva de palmeiras produtivas (BP) de piaçava amostradas no Quilombo Brejo Grande, localizado no Município de Ituberá, Bahia.

\begin{tabular}{lcccccc}
\hline \multirow{2}{*}{ Estatísticas } & \multicolumn{7}{c}{ Variáveis } \\
\cline { 2 - 7 } & HT estimada $(\mathrm{m})$ & $\mathrm{HE}(\mathrm{m})$ & $\mathrm{DB}(\mathrm{cm})$ & $\mathrm{DAP}(\mathrm{cm})$ & $\mathrm{NFC}$ & $\mathrm{NFT}$ \\
\hline Média & 9,0 & 1,5 & 28,5 & 28,6 & 2,3 & 1,4 \\
Máximo & 15,0 & 4,5 & 58,0 & 52,8 & 5,0 & 3,0 \\
Mínimo & 5,0 & 0,2 & 11,2 & 2,5 & 1,0 & 1,0 \\
CV\% & 19,5 & 53,7 & 35,7 & 25,4 & 41,1 & 41,9 \\
IC & $9,0 \pm 1,8$ & $1,5 \pm 0,8$ & $28,5 \pm 10,2$ & $28,6 \pm 7,3$ & $2,3 \pm 0,9$ & $1,4 \pm 0,6$ \\
\hline
\end{tabular}

TABELA 21: Estatística descritiva de coqueiros (COQ) de piaçava amostrados na área particular, localizada no Município de Canavieiras, Bahia.

\begin{tabular}{lcccccc}
\hline \multirow{2}{*}{ Estatísticas } & Variáveis & & \\
\cline { 2 - 7 } & HT estimada $(\mathrm{m})$ & $\mathrm{HE}(\mathrm{m})$ & $\mathrm{DB}(\mathrm{cm})$ & DAP $(\mathrm{cm})$ & NFC & NFT \\
\hline Média & 13,1 & 4,1 & 25,0 & 23,3 & 3,4 & 2,2 \\
Máximo & 21,0 & 9,8 & 40,4 & 35,9 & 8,0 & 4,0 \\
Mínimo & 4,0 & 1,0 & 12,4 & 14,7 & 1,0 & 1,0 \\
CV\% & 23,5 & 44,7 & 16,0 & 15,0 & 42,2 & 33,4 \\
IC & $13,1 \pm 3,1$ & $4,1 \pm 1,9$ & $25,0 \pm 4,0$ & $23,3 \pm 3,5$ & $3,4 \pm 1,5$ & $2,2 \pm 0,8$ \\
\hline
\end{tabular}

TABELA 22: Estatística descritiva de coqueiros (COQ) de piaçava amostrados no Quilombo Brejo Grande, localizado no Município de Ituberá, Bahia.

\begin{tabular}{lcccccc}
\hline \multirow{2}{*}{ Estatísticas } & HT estimada $(\mathrm{m})$ & $\mathrm{HE}(\mathrm{m})$ & $\mathrm{DB}(\mathrm{cm})$ & $\mathrm{DAP}(\mathrm{cm})$ & NFC & NFT \\
\hline Média & 10,9 & 2,8 & 37,6 & 31,5 & 4,3 & 1,9 \\
Máximo & 16 & 9 & 60 & 51,8 & 10 & 4 \\
Mínimo & 2 & 0,98 & 20 & 2,9 & 2 & 1 \\
CV\% & 19,0 & 48,5 & 27,0 & 25,6 & 31,3 & 47,3 \\
IC & $10,9 \pm 2,1$ & $2,8 \pm 1,3$ & $37,6 \pm 10,2$ & $31,5 \pm 8,1$ & $4,3 \pm 1,3$ & $1,9 \pm 0,9$ \\
\hline
\end{tabular}

Observe que as variáveis NFC e NFT apresentam elevada variabilidade em todas as condições analisadas (fase de desenvolvimento e local estudado). Nos dois ambientes estudados, as bananeiras em produção (BP) apresentaram menor número de capas (cerca de 2 capas) e tocos (cerca de 1 toco) em relação aos coqueiros (cerca de 3 a 4 capas e 2 tocos), o que já era de se esperar, já que, o número de capas está diretamente relacionado ao número de folhas verdes abertas e tal número aumenta com a idade da palmeira.

A capa está altamente relacionada com a produção de fibras de piaçava, sendo composta por fibra bruta e fitas. A quantificação desta variável é importante para se definir 
medidas de manejo para a espécie. Os tocos, que correspondem a pedaços de capas deixados na palmeira, após a extração da capa, também têm papel importante no manejo, pois serão aproveitados na próxima extração.

É importante destacar que a estimativa do número de 'capas' que foi feita pelos 'tiradores', antes da extração, embaixo da palmeira, foi menor que a quantidade real de capas contada pelo "tirador" após subir na palmeira.

A Figura 20 apresenta o resultado da comparação das médias de cada variável analisada (HT, HE, DB, DAP, NFC e NFT), a partir do teste t de variância combinada, ao nível de 5\% de significância, considerando as duas fases de produção da piaçava (BP e COQ) e as duas áreas estudadas (AP e QUI). Observe que, de uma maneira geral, para a grande maioria das variáveis analisadas, as médias são estatisticamente diferentes ( $\mathrm{P}<$ 0,05), confirmando, mais uma vez a heterogeneidade dos plantios tanto da área quilombola quanto da área particular, no que se refere às variáveis que, de alguma forma, podem estar relacionadas diretamente com a produção de fibras de piaçava.

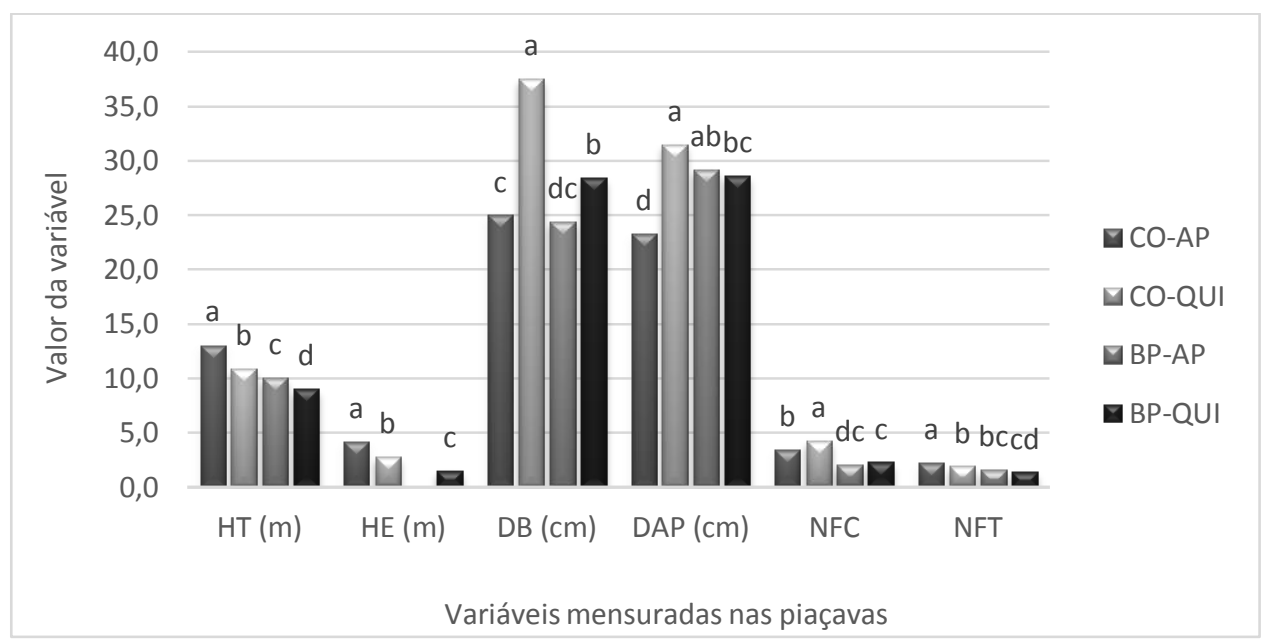

Figura 20: Médias ${ }^{19}$ das variáveis HT, HE, DB, DAP, NFC e NFT, das palmeiras produtivas de piaçava (BP e COQ) amostradas em duas plantações (área particular - AP e quilombola - QUI), localizadas no Estado da Bahia.

Os coqueiros apresentaram as maiores médias de altura (altura total e altura do estipe) e, os coqueiros mais altos foram registrados na propriedade particular $(\mathrm{HT}$ média $=$ $13,1 \mathrm{~m} \mathrm{e} \mathrm{HE}=4,1 \mathrm{~m}$ ).

As plantas COQ que já atingiram alturas superiores a $20 \mathrm{~m}$, devem ser explorados com mais critérios, devido aos riscos durante a subida e a extração da fibra vegetal, essas plantas fornecem frutos para o aproveitamento do mesocarpo, endocarpo e óleo vegetal das

\footnotetext{
${ }^{19}$ Médias seguidas de mesma letra não diferem estatisticamente pelo teste $t$ de variância combinada, ao nível de $5 \%$ de significância.
} 
sementes, também podem ser destinadas como porta sementes e alimento para fauna silvestre, até findar seu ciclo de vida.

Os maiores diâmetros das palmeiras (DB e DAP) foram registradas nos coqueiros quilombolas, apesar da média dos DAPs das palmeiras em produção da propriedade particular ter sido estatisticamente igual a média registrada nos coqueiros do Quilombo.

É importante ressaltar que as variáveis altura e diâmetro são muito importantes na caracterização da estrutura de formações vegetais, especialmente as florestais. Nas formações florestais, sejam nativas ou plantadas, estas variáveis apresentam alta correlação com a produção florestal, tanto em termos de volume de madeira quanto de estoque de biomassa, que são duas variáveis muito utilizadas na regulação da produção florestal CAMPOS; HELIO, 2013).

Portanto, estudos investigativos sobre a influência dessas duas variáveis na produção de fibras de piaçava devem ser essenciais para o estabelecimento de estratégias de manejo para a espécie.

\subsection{5 - Modelagem da produção de fibras de piaçava por palmeira (BP e COQ)}

As Tabelas 23 e 24 apresentam os valores dos coeficientes de correlação obtidos entre a variável produção de fibra bruta de piaçava (PFB) em quilogramas e as variáveis independentes registradas nos plantios: altura (H), idade do plantio (IDADE), Número de Folhas Verdes Abertas (NFA), DB e DAP.

Tabela 23: Valores de correlação entre produção de fibra bruta de piaçava (PFB) e variáveis independentes (IDADE, H, NFA, DB e DAP) para bananeiras em produção (BP) amostradas em dois plantios de piaçava, localizados no Estado da Bahia.

\begin{tabular}{ccccccc}
\hline & IDADE & H & NFA & DB & DAP & PFB \\
\hline IDADE & 1 & & & & & \\
H & 0,128 & 1 & & & & \\
NFA & $\mathbf{- 0 , 6 0 4 *}$ & 0,459 & 1 & & & \\
DB & $-0,415$ & $\mathbf{0 , 6 2 0 *}$ & $\mathbf{0 , 6 6 6 *}$ & 1 & & \\
DAP & $-0,137$ & 0,219 & 0,244 & 0,396 & 1 & \\
PFB & $\mathbf{- 0 , 5 0 6 *}$ & 0,392 & $\mathbf{0 , 6 0 6 *}$ & $\mathbf{0 , 8 5 6 *}$ & 0,361 & 1 \\
\hline (* significativo com $\mathrm{p}<0,05)$ & & & &
\end{tabular}


Tabela 24: Valores de correlação entre produção de fibra bruta de piaçava (PFB) e variáveis independentes (IDADE, H, NFA, DB e DAP) para coqueiros (COQ) amostrados em dois plantios de piaçava, localizados no Estado da Bahia.

\begin{tabular}{ccccccc}
\hline & IDADE & H & NFA & DB & DAP & PFB \\
\hline IDADE & 1 & & & & & \\
H & $\mathbf{0 , 5 3 4 *}$ & 1 & & & & \\
NFA & $-0,343$ & $-0,002$ & 1 & & & \\
DB & $-0,766^{*}$ & $-0,367$ & $\mathbf{0 , 5 0 1 *}$ & 1 & & \\
DAP & $-0,521^{*}$ & $-0,258$ & $\mathbf{0 , 5 3 4}$ & $0,920^{*}$ & 1 & \\
PFB & $-0,371$ & $-0,076$ & 0,468 & $\mathbf{0 , 5 8 7 *}$ & $\mathbf{0 , 6 1 3 *}$ & 1 \\
\hline
\end{tabular}

(* significativo com $\mathrm{p}<0,05)$

Observe que, para as bananeiras em produção (Tabela 23), a PFB apresentou maior correlação com as variáveis, número de folhas abertas das palmeiras (NFA) e diâmetro da base (DB). A variável $\mathrm{H}$, que é considerada uma das mais importantes para avaliar a produção florestal, se destacou neste estudo como uma das variáveis menos correlacionadas com a PFB nas bananeiras em produção de piaçava.

É importante observar ainda que, para as bananeiras em produção, a idade dos plantios analisados apresenta correlação relativamente alta, mas, negativa, com as variáveis NFA $(R=-0,604)$ e PFB $(R=-0,506)$. Portanto, existe certa tendência de redução do NFA com o aumento da idade. Contudo, para um plantio que visa produção, e cujas plantas encontram-se em fase de crescimento, este resultado é bem incoerente.

A variável NFA é a parte da palmeira mais diretamente relacionada com a produção de fibras e a produção de fibras deveria estar relacionada positivamente com a idade das palmeiras nos plantios. No entanto, não se pode deixar de considerar que durante o processo de exploração de fibras de piaçava, não se coleta todas as folhas. Segundo Gama et al (2009), o recomendável é que no processo de colheita de fibras de piaçava sejam retiradas, no máximo, 3 a 4 folhas (talas), por planta, e isto, de alguma forma, restringe a obtenção de alta correlação entre PFB e NFA, já que não se retira todas as folhas abertas da palmeira durante o processo de exploração para produção de fibras. Portanto, como neste estudo, tal recomendação foi seguida, o resultado da correlação entre PFB e NFA já era esperado, ou seja, não existência de correlação alta e positiva entre as duas variáveis.

No caso da correlação entre idade do plantio e PFB, a correlação encontrada também já era esperada, já que nos plantios avaliados não existe controle da idade das palmeiras, pois, numa mesma área existem palmeiras em diferentes fases de desenvolvimento e, dentro de cada fase, as palmeiras possuem diferentes idades. 
Consequentemente, não se pode afirmar que, num plantio com 50 anos, todas as plantas têm a mesma idade, pois, na realidade, todos os plantios analisados são inequiâneos.

Em função disto, pode-se afirmar que, para as condições dos plantios estudados, as variáveis idade do plantio e NFA não são indicadas para representar a produção de fibras brutas em bananeiras em produção.

No entanto, como as bananeiras em produção analisadas (considerando em conjunto, as duas áreas estudadas) estão distribuídas entre plantios cujas idades variam de 7 a 50 anos, era possível esperar a existência de tendência de aumento da PFB com a idade do plantio, caso esses plantios estivessem recebendo técnicas de manejo mais adequadas. Contudo, tal tendência não ocorreu $(R=-0,506)$. Provavelmente, esta correlação negativa, pode ser decorrente ou da falta de uma amostragem mais representativa nas duas áreas estudadas, quanto a PFB por palmeira, ou, também, devido ao próprio manejo que vem sendo adotado nas duas áreas. Ressalta-se, portanto, a importância da realização de um bom manejo nos plantios visando aumentar essa relação entre as variáveis.

Quanto aos coqueiros (Tabela 24), os resultados mostram que as variáveis que mais se correlacionam com a PFB são diâmetro da palmeira tomado a 1,30 m do solo (DB) e diâmetro tomado na base da palmeira (DAP).

A PFB nos coqueiros apresentou correlação baixa e negativa com idade dos plantios $(R=-0,371)$ e, correlação quase nula $(R=-0,076)$ com altura.

Quando se avalia o número de folhas abertas dos coqueiros, é possível observar que a correlação entre NFA e PFB é positiva, porém, baixa $(\mathrm{R}=0,468)$. Tal resultado mostra mais uma vez a incoerência dos dados, considerando que para os coqueiros, o esperado era que, quanto maior a PFB, maior seria NFA. Contudo, ressalta-se mais uma vez a impossibilidade de associar esta variável com a PFB, já que nas áreas estudadas, a recomendação de colher no máximo 3 a 4 folhas (talas), por planta é adotada.

Portanto, considerando tanto as bananeiras em produção, quanto os coqueiros, pode-se concluir que o diâmetro das palmeiras é a variável que melhor se correlaciona com a PFB, sendo que, no caso das bananeiras em produção, deve ser considerado o diâmetro da base (DB), e, no caso dos coqueiros, o diâmetro tomado a 1,30 m do solo (DAP).

Tomando como base os resultados encontrados na análise de correlação, foram testados, por meio de análise de regressão, vários modelos matemáticos alométricos (lineares e não lineares), com o objetivo de estimar a PFB de uma planta de piaçava (variável dependente do modelo) em função das variáveis independentes DB (no caso de bananeiras em produção) e DAP (no caso de coqueiros). Contudo, foram testados modelos 
envolvendo também a variável diâmetro combinada com a variável altura, já que, para modelos florestais, a combinação das variáveis diâmetro e altura das árvores proporcionam modelos com excelentes medidas de precisão.

As variáveis idade do plantio e NFA não foram consideradas no ajuste dos modelos em função das justificativas já descritas acima.

O emprego de equações de regressão que são geradas a partir de modelos alométricos, ajustados por meio de análise de regressão, constitui-se em uma das principais ferramentas para estimar determinada produção florestal de interesse, seja esta madeireira ou não, e, é base para o manejo sustentável de uma formação vegetacional, seja esta florestal ou não.

De todos os modelos testados, os quais envolveram a variável diâmetro (DB ou DAP) e também a variável altura, combinada com o diâmetro, foi verificado que o modelo que melhor se ajustou ao conjunto de dados analisados, tanto para bananeira em produção quanto para coqueiro foi um modelo que foi adaptado do modelo de Schumacher e Hall (1933), o qual se apresentava na forma não linear, isto é: $P F B=\beta_{0} \cdot D^{\beta_{1}} \cdot H^{\beta_{2}}$, em que:

$\mathrm{PFB}=$ Produção de fibra bruta $(\mathrm{kg})$ de uma palmeira (COQ ou BP)

$\beta_{0}, \beta_{1}, \beta_{2}=$ parâmetros do modelo

$\mathrm{D}$ = Diâmetro da palmeira em cm, sendo DB para o caso de BP e DAP² para o caso de COQ;

$\mathrm{H}=$ altura da palmeira $(\mathrm{m})$

O modelo de Schumacher e Hall tem sido o mais difundido na área florestal, para estimativa de volume de madeira e biomassa, especialmente por suas propriedades estatísticas, uma vez que resulta quase sempre em estimativas não tendenciosas (CAMPOS; LEITE, 2006).

A Tabela 25 apresenta o resultado do ajuste do modelo ajustado tanto para bananeiras em produção (BP) quanto para coqueiros (COQ).

Tabela 25: Estatísticas dos parâmetros, medidas de precisão e validação das equações de regressão ajustadas para estimar $\mathrm{PFB}$ em piaçavas produtivas ( $\mathrm{PB}$ e $\mathrm{CO}$ ), amostradas em dois plantios (AP e QUI), localizados no Estado da Bahia.

\begin{tabular}{l|lll|ll|l}
\hline \multirow{2}{*}{$\begin{array}{l}\text { Piaçavas } \\
\text { Produtivas }\end{array}$} & \multicolumn{3}{|l|}{$\begin{array}{l}\text { Estimativa dos Parâmetros do } \\
\text { Modelo }\end{array}$} & \multicolumn{2}{l|}{$\begin{array}{l}\text { Medidas de } \\
\text { Precisão }\end{array}$} & Validação do Modelo \\
\cline { 2 - 7 } & $\beta_{0}$ & $\beta_{1}$ & $\beta_{2}$ & $\mathrm{R}_{\text {ajustado }}^{2}$ & Syx\% & Teste de Wilcoxon \\
\hline BP & 0,00095454 & 1,90602 & $-2,60733$ & 0,86 & 42,15 & $\mathrm{Tc}=8 ; \mathrm{Ttb}=0 ; \mathrm{p}=0,6002 \mathrm{~ns}$ \\
COQ & 0,00814848 & 0,75454 & 0,35533 & 0,52 & 47,16 & $\mathrm{Tc}=12 ; \mathrm{Ttb}=2 ; \mathrm{p}=0,7353 \mathrm{~ns}$ \\
\hline
\end{tabular}


Observe na Tabela 25 que, embora o modelo de Schumacher e Hall modificado tenha sido selecionado para estimar a PFB em ambas as fases de desenvolvimento da piaçava (BP e COQ), a precisão do modelo é considerada baixa, com erros de estimativa iguais a $42 \%$ e $47 \%$ para PFB de Bananeira em Produção (BP) e de Coqueiro (COQ), respectivamente. Embora esta técnica de estimativa de PFB possa ser considerada

De acordo com o teste de Wilcoxon e considerando um nível de $5 \%$ de significância, os valores estimados pelo modelo de PFB ajustado, não difere significativamente dos valores reais de campo, indicando, portanto, que o modelo de Schumacher e Hall modificado que foi ajustado a partir de dados de PFB de piaçava, tanto de $\mathrm{BP}$ quanto de $\mathrm{COQ}$, pode ser uma técnica utilizada para estimar a PFB, a partir do DB e $\mathrm{H}$ de palmeiras, no caso de $\mathrm{BP}$, ou a partir de DAP e H, no caso de COQ.

Contudo, embora a modelagem tenha sido considerada estatisticamente válida para estimar a PFB de piaçava, as estimativas podem gerar erros na ordem de $40 \%$, e, neste sentido, recomenda-se que uma amostra mais representativa seja utilizada para o ajuste do modelo, visando minimizar o erro da estimativa.

A partir dos modelos ajustados foram estimados os valores de PFB para cada bananeira em produção e para cada coqueiro amostrados nas duas áreas estudadas, ou seja, comunidade quilombola e área particular. Para a comunidade quilombola, estima-se que a PFB é, em média, igual a 1,49 kg por palmeira (BP) e 3,60 kg por coqueiro. No caso da área particular, a PFB é, em média, igual a $0,59 \mathrm{~kg}$ por palmeira $(\mathrm{BP})$ e $2,35 \mathrm{~kg}$ por coqueiro. Isto equivale a dizer que a produção média das palmeiras produtivas ( $\mathrm{BP}+\mathrm{COQ})$ na área quilombola é, em média, igual a $2,10 \mathrm{~kg}$ e na área particular essa produção é igual a $1,90 \mathrm{~kg}$.

Considerando que a densidade estimada de palmeiras produtivas $(\mathrm{BP}+\mathrm{COQ})$ na área particular é igual a 545 piaçavas/ha, estima-se que a PFB nesta área seja igual a 1.035,5 kg/ha, enquanto na comunidade quilombola, como a densidade é maior, ou seja, 1037 palmeiras por hectare, essa produção média atinge $2.177,7 \mathrm{~kg} / \mathrm{ha}$.

\subsection{6 - Estoque Produtivo das Áreas Amostradas}

O estoque produtivo da piaçava nas duas áreas amostradas (área quilombola e área particular) foi observado em cada uma das 11 parcelas $^{20}$. Em ambas as áreas houve plantio

\footnotetext{
${ }^{20}$ As parcelas de 1 a 5 correspondem à área da propriedade particular e as parcelas de 6 a 11 correspondem à área quilombola.
} 
direto dos frutos de piaçava e a condução do plantio não previu reposição de plantas. Como as duas áreas foram cultivadas, o número de plantas encontradas no estágio de muda (patioba) e bananeira nova $(\mathrm{BN})$, foi em média, menor em relação ao número coqueiros (COQ) e bananeira produção (BP).

Foram analisadas 467 piaçavas, sendo que 156 (33\%) delas estavam na fase de coqueiro (produzindo fibras e frutos), 202 (43\%) estavam na fase de bananeira em produção (iniciando a fase de produção de fibra comercial), 59 (13\%) eram bananeiras novas e $50(11 \%)$ eram mudas ou patiobas (Tabela 26).

Tabela 26: Percentual de Piaçavas por Fase de Desenvolvimento em cada Parcela Amostrada.

\begin{tabular}{cccccccccccc}
\hline Fase de Desenvolvimento & \multicolumn{11}{c}{ Parcelas Amostrais } \\
\cline { 2 - 13 }$(\%)$ & 1 & 2 & 3 & 4 & 5 & 6 & 7 & 8 & 9 & 10 & 11 \\
\hline Coqueiros (\%) & 16 & 49 & 56 & 27 & 79 & 36 & 42 & 46 & 26 & 0 & 8 \\
Bananeiras (\%) & 16 & 8 & 19 & 30 & 13 & 46 & 45 & 44 & 66 & 48 & 88 \\
Bananeiras Novas (\%) & 28 & 8 & 0 & 23 & 3 & 14 & 9 & 7 & 8 & 42 & 3 \\
Patiobas (\%) & 40 & 35 & 25 & 20 & 5 & 5 & 3 & 2 & 0 & 10 & 0 \\
\hline
\end{tabular}

A quantidade de coqueiro variou bastante entre as 11 parcelas amostradas, mesmo sendo plantadas nos mesmos períodos e localizadas umas próximas das outras, não é possível estabelecer um modelo, um comportamento. A Tabela 26 indica que as quatro fases ocorreram em 9 parcelas, somente em 4 parcelas alguma das fases é inexistentes: a parcela 3 não apresentou $\mathrm{BN}$; a parcela 09 e 11 não apresentaram mudas (patiobas); e a parcela 10 não apresentou plantas na fase coqueiro. As parcelas 09 e 11 têm em comum as maiores proporções de piaçavas na fase BP e essas plantas não produzem frutos, o que pode justificar a ausência de mudas (patiobas) nas parcelas. As mudas existentes na parcela 10 são germinações tardias dos frutos plantados há aproximadamente 07 anos atrás.

A idade dos plantios variou de 7 a 50 anos. Das 11 parcelas amostradas, uma tinha 7 anos (parcela 10), duas tinham 14 anos, duas tinham 18 anos e, as demais, tinham idade superior a 30 anos. Em três parcelas no quilombo não foram encontrados indivíduos mortos. Em todas as cinco parcelas da propriedade foram encontradas piaçavas na fase coqueiro mortas, algumas tombadas, outras com estipe em pé e sem folhas.

\subsubsection{1 - Potencial produtivo da piaçava no quilombo}

No Quilombo Brejo Grande foram encontradas em média 1.250 palmeiras por hectare, considerando todos os estágios de desenvolvimento. Como o território quilombola 
possui 78 ha de plantio de piaçava, estima-se, com base no levantamento realizado, que o Quilombo tem, aproximadamente, 97.500 palmeiras de piaçava, sendo que 80.925 (83\%) estão nos estágios de desenvolvimento coqueiro e bananeira em produção (COQ e BP), isto é, aptas à extração comercial.

AQBGI administra um galpão de produção de vassouras dentro do quilombo, em parceria com COOPAFBASUL, adquire e vende fibras brutas, limpas e cortadas, dos quilombolas da região e agricultores familiares. A associação e cooperativa ainda não estabeleceu um canal de comercialização dos produtos oriundos da piaçava da Bahia.

O território quilombola vai muito além dos plantios de piaçava aqui apontados, a comunidade cultiva outras espécies florestais em seus roçados, além de áreas com Mata Atlântica, córregos, lago, estradas e áreas residenciais e de lazer, como o campo de futebol do Sr. Amâncio, veterano na região.

Especificamente nos 40 plantios, identificados, como sendo de famílias Quilombolas de Brejo Grande, a Tabela 27 apresenta os plantios de piaçava com as suas respectivas áreas, quantidade total de palmeiras encontradas e quantidade de palmeiras no estágio de coqueiro (COQ) e de bananeira em produção (BP). A estimativa foi estrapolada para menurar a quantidade de plantas totais e plantas produtivas (COQ e BP) existentes em cada plantio quilombola.

Tabela 27: $\mathrm{N}^{\circ}$ de piaçava por plantio e $\mathrm{N}^{\circ}$ de COQ e BP por plantio do Quilombo Brejo Grande conforme levantamento realizado e informações dos extrativistas da piaçava

\begin{tabular}{|c|c|c|c|c|}
\hline $\mathbf{N}^{\circ}$ & Plantio de Piaçava do Sr. ou Sra. & Tamanho (ha) & $\begin{array}{c}\mathbf{N}^{\circ} \text { Piaçava / } \\
\text { Plantio }\end{array}$ & $\begin{array}{c}\mathrm{N}^{\circ} \text { COQ e BP / } \\
\text { Plantio }\end{array}$ \\
\hline 1 & Cal 40 ha & 4 & 5000 & 4150 \\
\hline 2 & Agnaldo & 4 & 5000 & 4150 \\
\hline 3 & João & 2 & 2500 & 2075 \\
\hline 4 & André & 4 & 5000 & 4150 \\
\hline 5 & Elias & 15 & 2500 & 2075 \\
\hline 6 & Diorge -52 ha & 2 & 18750 & 15562,5 \\
\hline 7 & Amâncio & 0,5 & 2500 & 2075 \\
\hline 8 & Carlos & 2 & 625 & 518,75 \\
\hline 9 & Lió & 1 & 2500 & 2075 \\
\hline 10 & Manoel Ângelo & 1 & 1250 & 1037,5 \\
\hline 11 & Domingos & 2 & 1250 & 1037,5 \\
\hline 12 & Liotéro & 2 & 2500 & 2075 \\
\hline 13 & Manoel Dison & 4 & 5000 & 2075 \\
\hline 14 & Evandro & 1 & 1250 & 4150 \\
\hline 15 & Zé Rocha & 1 & 1250 & 1037,5 \\
\hline 16 & Manoel Siríaco & 1 & 1250 & 1037,5 \\
\hline 17 & Aló́sio de Jesus -10 ha & 2 & 2500 & 1037,5 \\
\hline 18 & Antônio Conceição -50 ha & 1 & 1250 & 2075 \\
\hline 19 & Nelson & & & 1037,5 \\
\hline
\end{tabular}




\begin{tabular}{|l|c|c|c|c|}
\hline 20 & Domingo Rosário & 2 & 2500 & 2075 \\
\hline 21 & Domingo Araújo & 2 & 2500 & 2075 \\
\hline 22 & Ducan & 1,5 & 1875 & 1556,25 \\
\hline 23 & Emília & 1 & 1250 & 1037,5 \\
\hline 24 & Braz & 2 & 2500 & 2075 \\
\hline 25 & Antônio Francisco & 2 & 2500 & 2075 \\
\hline 26 & André Ricardo - 50 ha & 2 & 2500 & 2075 \\
\hline 27 & Antônia das Neves & 1 & 1250 & 1037,5 \\
\hline 28 & Domingo Mantídeo & 2 & 2500 & 2075 \\
\hline 29 & Francisco & 3 & 3750 & 3112,5 \\
\hline 30 & Cosme - 15 ha & 1 & 1250 & 1037,5 \\
\hline 31 & Sabina & 1 & 1250 & 1037,5 \\
\hline 32 & Damiana Anja & 1 & 1250 & 1037,5 \\
\hline 33 & Antônio de Novaes & 1 & 1250 & 1037,5 \\
\hline 34 & Maria Caetano & 1 & 1250 & 1037,5 \\
\hline 35 & Pedro -3 ha & 1 & 1250 & 1037,5 \\
\hline 36 & Mabo - 25 ha & 1 & 1250 & 1037,5 \\
\hline 37 & André da Moto & 1 & 1250 & 1037,5 \\
\hline 38 & Aurélio & 1 & 1250 & 1037,5 \\
\hline 39 & Adonia Conceição dos Santos & 8 & 6250 & 8300 \\
\hline 40 & Adelino & 5 & 1250 & 5187,5 \\
\hline 41 & Zeu & 1 & $\mathbf{1 1 6 . 2 5 0}$ & $\mathbf{9 6 . 4 8 7 , 5 0}$ \\
\hline \multicolumn{2}{|c|}{ Total } & & $\mathbf{8 0 . 9 2 5}$ \\
\hline
\end{tabular}

O plantio número 06 (Tabela 27) não está sendo considerada neste estudo, pois os atuais moradores não se consideram quilombolas e não são reconhecidos como tal pela comunidade, apesar de residirem dentro do território quilombola. Adquiriram esta área dos parentes quilombolas do Sr. Amâncio que repassam suas áreas aos outros agroextrativistas ou produtores interessados. Os plantios números: 10,12,17,30 e 32 foram selecionados para implantação das parcelas no quilombo, essas áreas estavam a mais de dois anos sem exploração, com exceção da parcela do Cosme (número 10) em que as plantas estavam com 7 anos de idade, durante o levantamento em 2014, quando sofreram a primeira exploração.

Em três parcelas no quilombo não foram encontrados indivíduos mortos. Nas parcelas 06, 09 e 11 do quilombo foram encontrados indivíduos de palmeiras mortas, essas são as parcelas mais antigas do quilombo variando a idade entre 40 a 50 anos. A parcela 10 não apresentou plantas na fase COQ. Todas as parcelas apresentaram plantas na fase BP e, somente as parcelas 09 e 11 não apresentaram plantas na fase de patioba.

A parcela 09 do Sr. Manoel apresentou o maior numero de plantas, seguida pela parcela 11 e 06 do Sr. Liotério. A parcela 06 apresentou o maior número de plantas na fase coqueiro, alta densidade de plantas, podendo ser classificada como a parcela mais antiga avaliada neste estudo. 
O número de plantas com inflorescência em cada parcela, no quilombo, variou de cinco plantas com presença de inflorescência por parcela a 14 plantas com inflorescência, em janeiro de 2014. A parcela 06 apresentou 11 plantas com inflorescência e a parcela 08 da Sra. Damiana apresentou 14 plantas com inflorescência. A média de plantas com inflorescência foi de 8,2 plantas por parcela.

O número de plantas com cachos de frutos variou entre uma planta com fruto a onze plantas com fruto por parcela. A parcela 08 apresentou onze plantas com cachos de frutos e a parcela 06 apresentou oito plantas com cachos de frutos. A média de plantas com cacho de frutos no quilombo, em janeiro de 2014, foi de 5,2 plantas por parcela, incluindo a parcela 10 que não possui plantas na fase de coqueiro.

\subsubsection{2 - Potencial produtivo da piaçava do produtor local}

A propriedade particular localizada em Canavieiras, apresentou, considerando as cinco parcelas implantadas, 835 palmeiras por hectare, em média, distribuídas entre todos os estágios de desenvolvimento considerados neste estudo. $\mathrm{O}$ estoque estimado de palmeira nos 50 hectares de plantio, disponibilizados para pesquisa, é de aproximadamente 41.750 palmeiras, sendo que $27.250(65,3 \%)$ piaçavas são produtivas, ou seja, estão nos estágios coqueiro (COQ) e bananeira em produção (BP).

A área disponibilizada para pesquisa, dentro da propriedade, é composta pelos plantios de piaçava entra a vegetação da Mata Atlântica, pelas vias de acesso, áreas abertas (capoeiras) e um núcleo residencial. Apesar dos plantios serem contínuos, ao longo das vias de acesso e escarpas das serras, o produtor não sabe afirmar o tamanho em hectares da área plantada com piaçava. Portanto não é correto extrapolar os valores de densidade de plantas por hectare para a totalidade dos 50 hectares, somente um levantamento detalhado da quantidade de área da propriedade com piaçava poderia apontar uma estimativa real de plantas nesses 50 hectares.

Em todas as cinco parcelas amostradas foram identificadas plantas produtivas na fase COQ e BP, somente a parcela 03 não apresentou plantas na fase de bananeira nova, todas as outras parcelas apresentaram plantas em todas as fases. A parcela 05 apresentou o maior numero de plantas na propriedade com 39 plantas, sendo 31 na fase COQ, 5 na fase $\mathrm{BP}$, uma na fase $\mathrm{BN}$ e duas patiobas. Apesar dos plantios apresentarem 50 anos de idades como no quilombo, esses apresentam um menor número de plantas por parcela. 
Em todas as cinco parcelas na propriedade foram encontradas piaçavas na fase coqueiro mortas, algumas tombadas e outras com estipe em pé, mas sem folhas. Nas parcelas 01 e 05 foi encontrada uma planta morta; nas parcelas 03 e 04 foram encontradas duas plantas mortas; e na parcela 02 foram encontradas três piaçavas coqueiros mortas.

As plantas com sinais de perda de vitalidade, seja devido à extração danosa ou ataque de pragas e doenças, foram classificadas como plantas 'danificadas' o que corresponde ao entendimento extrativista de piaçava 'pasmada'. A sanidade da planta é percebida pelo número de folhas verdes e secas, bem como a presença de pelo menos uma folha fechada, protegendo o 'olho' da palmeira ou meristema apical. Na parcela 01 não foi encontrada planta 'danificada'; nas parcelas 02, 04 e 05 identificaram-se duas plantas 'danificadas' em cada uma das parcelas; e na parcela 03 foram identificadas cinco plantas 'danificadas'.

Quando uma planta na fase de desenvolvimento BP é sobre explorada, a planta perde a estabilidade e diante deste dano, diminui a produtividade de folhas e fibras, podendo chegar à morte se não for tomada medidas de controle. Uma pratica adota pelo produtor e amarrar os pecíolos das folhas para aumentar a estabilidade da planta, bem como fazer explorações bianuais em plantas nessa fase de desenvolvimento.

O levantamento na propriedade foi realizado em outubro de 2013, época em que as plantas apresentam uma maior quantidade de inflorescências fechadas ('busas') que entre os meses de março, abril e maio frutificarão. Neste sentido a parcela 01 apresentou duas plantas com inflorescência; parcela 02 nove plantas com inflorescência; parcela 03 doze plantas; parcela 04 cinco plantas; e parcela 05 apresentou dezoitos plantas com inflorescência. A presença de frutos nas plantas variou entre zero e seis plantas por parcela: parcela 01 e 04 não apresentaram coqueiros com frutos; parcelas 05 e 03 apresentaram seis plantas com frutos; e parcela 02 apresentou cinco plantas com cachos de frutos.

Comparando-se as duas áreas amostradas, Ituberá e Canavieiras, observa-se que o plantio quilombola tem maior densidade de plantas por área, apresenta uma maior quantidade de plantas na fase de bananeira em produção (BP) e pouquíssimas plantas na fase patioba (Tabela 28). No quilombo $25 \%$ das plantas estão na fase coqueiro e $58 \%$ na fase BP, o que reflete na regeneração natural com apenas 3,4\% das plantas na fase de patioba. Em Canavieiras, por outro lado, 48,5\% das plantas estavam na fase COQ e 16,8\% na fase de BP e uma parcela significativa, $23 \%$ das plantas, estavam na fase de patioba. 
Tabela 28: Médias do $\mathrm{N}^{\circ}$ de plantas por hectare (ha) e $\mathrm{N}^{\circ}$ coqueiro, $\mathrm{BP}, \mathrm{BN}$, Patioba, nos dois sistemas produtivos avaliados.

\begin{tabular}{|c|c|c|c|c|c|c|c|c|c|}
\hline \multirow{2}{*}{$\begin{array}{c}\text { Sistema } \\
\text { Produtivo }\end{array}$} & $\begin{array}{c}\mathrm{N}^{\circ} \sum \\
\text { Planta/ha }\end{array}$ & $\begin{array}{c}\mathrm{N}^{\circ} \\
\mathrm{COQ} / \mathrm{ha}\end{array}$ & $\%$ & $\begin{array}{c}\mathrm{N}^{\circ} \\
\mathrm{BP} / \mathrm{ha}\end{array}$ & $\%$ & $\begin{array}{c}\mathrm{N}^{\circ} \\
\mathrm{BN} / \mathrm{ha}\end{array}$ & $\%$ & $\begin{array}{c}\mathrm{N}^{\circ} \\
\text { Patioba/h } \\
\mathrm{a}\end{array}$ & $\%$ \\
\hline Brejo Grande & 1.250 & 312,5 & 25 & 725 & 58 & 170,83 & 13,7 & 41,66 & 3,4 \\
\hline Canavieiras & 835 & 405 & 48,5 & 140 & 16,8 & 90 & 10,8 & 200 & 23 \\
\hline
\end{tabular}

Com menos indivíduos por área, as parcelas em Canavieiras, permitem mais entrada de luz e pela elevada presença de coqueiros tem mais material propagativo. As doenças e estado de sanidade das plantas, presença de indivíduos mortos e muitos buracos no chão, formados após a queda de palmeiras, são indicativos de que em Canavieiras a condução do plantio, e a extensa área contínua plantada, podem estar agravando os problemas para o produtor.

O inventário comunitário da piaçava realizado junto ao Povo Pataxó apresentou a densidade média de 402,3 indivíduos por hectare (indivíduos em todos os estágios de desenvolvimento), aproximadamente $45 \%$ desses indivíduos estão na fase produtiva. As áreas manejadas pela comunidade indígena ainda correspondem em sua maior parte, em áreas de mata em estágios sucessionais secundários a clímax e, o manejo tradicional da piaçava ainda não considera a etapa de plantio de piaçava, o que explica a baixa densidade de planta por hectare encontrada pelos pesquisadores (GAMA et al., 2009).

Em Santa Cruz de Cabrália/Bahia, foi realizado um inventário florestal em nove áreas, incluindo áreas de reserva legal e demais, da empresa de papel e celulose Veracell S.A. com objetivo de quantificar as piaçavas produtivas. O censo da piaçava apontou uma densidade populacional de 14 indivíduos produtivos por hectare (BERGAMO, 2007).

\subsection{7 - Produtividade de Fibra por Planta}

A produção média de fibra de piaçava foi obtida a partir da amostragem de 42 plantas distribuídas nas duas áreas estudadas (AP e QUI) e entre as duas fases de produção das palmeiras (BP e COQ). No total, a produção de fibra bruta foi realizada em 22 BP e 20 COQ.

As Tabelas 29 e 30 apresentam, respectivamente, os valores de produção média de fibra bruta registrada em plantas de piaçava na fase $\mathrm{BP}$ e na fase $\mathrm{COQ}$, com os correspondentes valores de altura média das palmeiras e número de folhas. 
Tabela 29 - Estatísticas da produção de fibras com correspondentes valores de altura e número de folhas registradas em palmeiras piaçavas, fase Bananeira em Produção, em dois plantios localizados na Bahia.

\begin{tabular}{cccc}
\hline ESTATÍSTICA & ALTURA PALMEIRA (m) & $\mathbf{N}^{\circ}$ FOLHAS & FIBRA (Kg) \\
\hline Média & 9,25 & 5,68 & 1,06 \\
Desvio padrão & 1,92 & 1,76 & 1,36 \\
C.V. $(\%)$ & 20,74 & 30,91 & 127,64 \\
\hline
\end{tabular}

Tabela 30 - Estatísticas da produção de fibras com correspondentes valores de altura e número de folhas registradas em palmeiras piaçavas, fase Coqueiro, em dois plantios localizados na Bahia.

\begin{tabular}{cccc}
\hline ESTATÍSTICA & ALTURA PALMEIRA (m) & $\mathbf{N}^{\circ}$ FOLHAS & FIBRA (Kg) \\
\hline Média & 12,39 & 11,50 & 3,68 \\
Desvio padrão & 1,88 & 2,70 & 2,63 \\
C.V. $(\%)$ & 15,15 & 23,52 & 71,55 \\
\hline
\end{tabular}

Em média, a produção de fibra para uma BP, considerando as duas áreas de estudo, foi igual a aproximadamente $0,92 \mathrm{~kg} /$ planta. Contudo, essa produção apresentou alta variabilidade entre as palmeiras BP amostradas $(\mathrm{CV}=106,4 \%)$. A maior produção de fibra extraída por planta foi igual a 3,54 kg de fibra vegetal, e foi registrada em uma palmeira da comunidade quilombola, e, a menor produção foi igual a $0,09 \mathrm{~kg}$, registrada em uma palmeira da área particular.

No caso dos coqueiros, a produção média de fibras foi igual a 3,68 kg/planta, e, da mesma forma que o observado na $\mathrm{BP}$, a variabilidade também foi bastante alta $(\mathrm{CV}=$ $71,5 \%)$. O coqueiro com maior produção de fibras atingiu $10,73 \mathrm{~kg}$ e o de menor produção atingiu $0,285 \mathrm{~kg}$.

Segundo informações de quilombolas e técnicos extensionistas, a produção média por hectare de plantios de piaçava, com 1.111 palmeiras por hectare, varia de 300 a 500 arrobas de fibra bruta, sendo que, para 300 arrobas, a produtividade média é de 4,05 kg de fibra bruta/planta/ano, e, para 500 arrobas a produtividade média é de $6,75 \mathrm{~kg}$ de fibra bruta/planta/ano. Em áreas de ocorrência natural da piaçava, onde predomina o extrativismo, a produtividade média é de $1,5 \mathrm{~kg}$ de fibra/planta e nas áreas plantadas a produtividade é de 3,0 kg de fibra/planta. Um trabalhador experiente chega a colher $45 \mathrm{~kg}$ de piaçava bruta/dia (rende $30 \mathrm{~kg}$ de material limpo).

Neste estudo, considerando as duas áreas amostradas, a média de produção das palmeiras produtivas amostradas (20 COQ e $22 \mathrm{BP}$ ) foi igual a 2,3 kg/planta, diferindo dos dados dos produtores e também de alguns pesquisadores, como Bondar (1942), Moreau (1997), Silva (2002), Cantuária (2008) e Gama et al. (2009). 
No estudo desenvolvido por Silva (2002), realizado em um plantio de piaçava, foi verificado que uma planta $\mathrm{BP}$ produz $0,92 \mathrm{~kg} /$ planta e uma planta COQ produz 1,28 $\mathrm{kg} /$ planta. Tais valores foram os que mais se aproximaram dos resultados encontrados neste levantamento, em que palmeiras BP produziram em média 1,1 kg/planta (Tabela 2.14) e coqueiros $3,7 \mathrm{~kg} /$ planta (Tabela 2.15). No estudo de Silva (2002) foram mensuradas 50 palmeiras, sendo 25 no estágio BP e 25 no estágio COQ.

Moreau (1997) também quantificou a produção de fibras em um plantio de piaçava com 20 anos, plantado no espaçamento $3 \times 3 \mathrm{~m}$, e, selecionou 150 palmeiras, mas, não as diferenciou em estágio de desenvolvimento (BP e COQ). $\mathrm{O}$ autor encontrou uma produção média de $3,32 \mathrm{~kg} /$ planta, com coeficiente de variação de $25,58 \%$.

As diferenças registradas entre os resultados deste estudo e os outros estudos citados acima, possivelmente estão relacionadas a variáveis como: diferentes ciclos de extração, diferentes qualidades de sítio (características do solo, tipo de clima etc), diferentes idades dos plantios, homogeneidade dos plantios, técnicas de manejo aplicadas, intensidade de amostragem, entre outras etc.

Após mais de um ano de implantação das 11 parcelas constatou-se que as parcelas 01, 03 e 04 da propriedade em Canavieiras foram parcialmente alteradas e as parcelas $02 \mathrm{e}$ 05 foram totalmente alteradas. Deste modo não foi possível, nessas duas últimas parcelas, novas análises de produtividade por planta. As parcelas 06 e 10 no quilombo foram completamente alteradas, havendo inclusive a retirada de todas as palmeiras de piaçava da parcela 10.

\subsubsection{Produtividade de Fibra por Planta do Quilombo}

No quilombo onde os plantios foram formados com espaçamentos empíricos, no 'olho', foram encontradas uma média de 1.250 plantas/ha de todas as fases de desenvolvimento, em plantios entre 07 e 50 anos de idade. A produtividade média por planta foi de 3,3 kg/planta/ano, com coeficiente de variação de $85,64 \%$, neste caso foram mensuradas 22 plantas, sendo 12 plantas no estágio de desenvolvimento de BP e 10 plantas COQ.

A parcela 09 do Sr. Manoel apresentou os maiores valores de produção por planta, com uma média de 7,79 kg/planta na fase COQ e o terceiro maior valor de produção de fibra na fase BP com 1,71kg/planta (Tabela 31). 
Tabela 31: Produção média de fibra $(\mathrm{kg})$ e número médio de folhas por fase de desenvolvimento no quilombo.

\begin{tabular}{|c|c|c|c|c|}
\hline \multirow[b]{2}{*}{ PARCELAS } & \multicolumn{2}{|c|}{ COQUEIRO (MÉDIA) } & \multicolumn{2}{|c|}{ BANANEIRA PRODUTIVA (MÉDIA) } \\
\hline & FIBRAS (KG) & $\mathrm{N}^{\circ}$ FOLHAS & FIBRAS (KG) & $\mathrm{N}^{\circ}$ FOLHAS \\
\hline 6 & 2,62 & 9,5 & 0,53 & 5,0 \\
\hline 7 & 4,27 & 10,5 & 3,95 & 9,5 \\
\hline 8 & 5,71 & 16,5 & 2,11 & 6,5 \\
\hline 9 & 7,79 & 11,0 & 1,71 & 4,5 \\
\hline 10 & 0 & 0 & 0,46 & 6,0 \\
\hline 11 & 6,53 & 13,5 & 0,94 & 6,0 \\
\hline
\end{tabular}

A parcela 06 do Sr. Liotério apresentou a mais baixa produtividade de fibra, entre as parcelas mais maduras, com uma média de 2,62 kg/planta COQ e uma média de 0,53 $\mathrm{kg} /$ planta na fase BP. A parcela 06 apresentou um total de 58 plantas e a parcela 11 apresentou 59 plantas, as maiores densidades de plantas por área amostrada, em relação à totalidade de parcelas implantadas neste estudo. Isso possivelmente está provocando muita sombra e fazendo com que as plantas reduzam sua produtividade de fibra. Outro fator que pode está afetando é a baixa intensidade de extração, neste caso um intervalo de 48 messes.

A parcela 10 do Sr. Cosme não possui plantas na fase de COQ e estava com aproximadamente sete anos de idade, sendo esta extração a primeira do plantio. A parcela 11 também pertence ao Sr. Liotério e apresentou uma média de $0,94 \mathrm{~kg}$ de fibra por planta na fase BP, esta parcela fica próxima a parcela 06 , estão localizadas no mesmo tipo de solo e foram plantadas com aproximadamente 10 anos de intervalo, ou seja, a parcela 11 é mais jovem do a parcela 06.

A parcela 08 da quilombola Sra. Damiana, apresentou o maior número médio de folhas por planta na fase COQ, média de 16,5 folhas por planta, com 41 plantas por área amostrada. Essa parcela apresentou boa luminosidade e plantas de piaçava na fase COQ de pequena altura.

Para averiguar a variação da produtividade por planta em um ciclo de treze meses, realizaram-se novas extrações (Tabela 32) nas plantas que foram preservadas pelos quilombolas. Na primeira extração foram 12 plantas na fase BP e na segunda extração restaram 7 plantas dessas 12 plantas na fase BP. As plantas na fase COQ correspondiam a 10 plantas na primeira extração e 09 plantas COQ na segunda extração. 
Tabela 32: Produção média de fibra vegetal no ciclo de 13 messes em plantas COQ e BP do Quilombo Brejo Grande de Ituberá.

\begin{tabular}{|c|c|c|c|c|}
\hline \multirow[b]{2}{*}{ PARCELAS } & \multicolumn{2}{|c|}{ COQUEIRO } & \multicolumn{2}{|c|}{ BANANEIRA PRODUTIVA } \\
\hline & $1^{\mathrm{a}}$ EXTRAÇÃO & $2^{\mathrm{a} a}$ EXTRAÇÃO & $1^{\text {a }}$ EXTRAÇÃO & $2^{\mathrm{a}}$ EXTRAÇÃO \\
\hline 7 & 5,40 & 4,12 & 1,88 & 1,92 \\
\hline 7 & 3,15 & 2,53 & 0 & 0 \\
\hline 7 & 5,52 & 3,33 & 0 & 0 \\
\hline 8 & 7,50 & 2,62 & 3,54 & 1,09 \\
\hline 8 & 3,92 & 3,26 & 0,68 & 0,71 \\
\hline 9 & 4,85 & 2,58 & 0,44 & 0,30 \\
\hline 9 & 10,73 & 4,77 & 2,99 & 1,57 \\
\hline 11 & 6,84 & 3,24 & 1,25 & 1,35 \\
\hline 11 & 6,21 & 5,78 & 0,64 & 0,36 \\
\hline
\end{tabular}

Observou-se que as plantas na fase COQ mensuradas no quilombo apresentaram uma menor massa de fibra na segunda extração. Na fase de BP três plantas apresentaram uma maior massa na segunda extração, após treze meses, e quatro plantas apresentaram massa inferior ao da primeira extração. A parcela 07 possui três plantas COQ devido à dificuldade de definir precisamente em que fase do desenvolvimento estava essa planta na primeira extração.

\subsubsection{2 - Produtividade de Fibra por Planta da Propriedade}

Em Canavieiras o plantio também foi implantado num espaçamento $3 \times 3$ e atualmente possui uma densidade de 835 plantas/ha, plantio com 40 a 50 anos de idade. A produtividade por planta foi de $1,2 \mathrm{~kg} /$ planta/ano, com coeficiente de variação de $100 \%$, neste caso foram mensuradas 20 plantas, sendo 10 plantas no estágio de desenvolvimento de BP e 10 plantas COQ.

A parcela 04 apresentou a menor massa de fibras vegetais brutas, tanto nas plantas na fase $\mathrm{BP}$ como na fase COQ. A parcela 03 apresentou a maior massa de fibras vegetais nas plantas na fase de COQ com uma média de 3,35 kg de fibra por planta (Tabela 33).

Tabela 33: Produção média de fibra e número de folhas por fase de desenvolvimento da piaçava e em cada parcela da propriedade particular de Canavieiras.

\begin{tabular}{c|cc|cc}
\hline \multirow{2}{*}{ PARCELAS } & \multicolumn{2}{|c|}{ COQUEIRO (MÉDIA) } & \multicolumn{2}{c}{ BANANEIRA PRODUTIVA (MÉDIA) } \\
\cline { 2 - 5 } & FIBRAS $($ KG) & $\mathrm{N}^{\circ}$ FOLHAS & FIBRAS $(\mathrm{KG})$ & $\mathrm{N}^{\circ}$ FOLHAS \\
\hline 1 & 1,26 & 13 & 0,72 & 6,5 \\
2 & 2,67 & 10 & 0,23 & 4,5 \\
3 & 3,35 & 11 & 0,38 & 5,0 \\
4 & 0,78 & 10,5 & 0,10 & 5,0 \\
5 & 1,84 & 9,5 & 0,83 & 4,0 \\
\hline
\end{tabular}

A parcela 01 apresentou o maior número de folhas nas duas fases produtivas de desenvolvimento das plantas, BP e COQ, esse elevado número de folhas pode ser 
justificado pela grande insolação da área, essa parcela apresentou o menor número de plantas por área amostrada, 25 plantas, entre as onze parcelas implantadas nas duas áreas produtivas. Dessas 25 plantas 10 plantas são mudas (patiobas), 07 bananeira nova (BN) e $04 \mathrm{BP}$ e $04 \mathrm{COQ}$. Essa área foi plantada a mais de 50 anos, porém muitas plantas morreram e atualmente a regeneração natural predomina. A massa média de fibra produzida foi de $0,72 \mathrm{~kg}$ por planta na fase $\mathrm{BP}$ e uma média de $1,26 \mathrm{~kg}$ de fibra por planta na fase COQ.

$\mathrm{Na}$ propriedade particular em Canavieiras para averiguar a variação da produtividade por planta o ciclo foi de 15 meses, ou seja, o intervalo entre as extrações foi superior ao do quilombo. Também nesta área o proprietário não conseguiu manter a integridade das plantas amostradas. Na primeira extração foram 10 plantas na fase BP e na segunda extração restaram 4 plantas dessas 10 plantas na fase BP. As plantas na fase COQ correspondiam a 10 plantas na primeira extração e passou para 08 plantas COQ na segunda extração. A Tabela 34 apresenta a massa de fibra vegetal na primeira e segunda extração.

Tabela 34: Produção média de fibra vegetal no ciclo de 15 meses em plantas COQ e BP na propriedade.

\begin{tabular}{c|cccc}
\hline \multirow{2}{*}{ PARCELAS } & \multicolumn{2}{c}{ COQUEIRO } & \multicolumn{2}{c}{ BANANEIRA PRODUTIVA } \\
\cline { 2 - 5 } & $1^{\mathrm{a}}$ EXTRAÇÃO & $2^{\mathrm{a}}$ EXTRAÇÃO & $1^{\mathrm{a}}$ EXTRAÇÃO & $2^{\mathrm{a}}$ EXTRAÇÃO \\
\hline 1 & 0,29 & 2,2 & 0,23 & 0 \\
1 & 2,23 & 4,83 & 1,2 & 0 \\
2 & 1,31 & 1,66 & 0,24 & 0,19 \\
2 & 4,02 & 1,65 & 0,22 & 0 \\
3 & 3,60 & 3,81 & 0,57 & 0 \\
3 & 3,11 & 3,64 & 0,2 & 0,08 \\
4 & 1,00 & 2,39 & 0,09 & 0,11 \\
4 & 0,59 & 1,82 & 0,11 & 0,08 \\
\hline
\end{tabular}

Observa-se que as plantas na fase COQ que foram analisadas na propriedade, quatro plantas apresentaram uma menor massa de fibra na segunda extração e, quatro plantas COQ apresentaram maior massa na segunda extração. Na fase de BP três plantas apresentaram uma menor massa de fibra na segunda extração, após quinze meses, somente uma planta apresentou massa superior à massa da primeira extração.

Possivelmente as plantas na fase de COQ que apresentaram maior massa na segunda extração, após 15 meses da primeira extração, foram decorrentes de um maior intervalo entre as extrações, diferentes 'tiradores' em cada uma dessas avaliações e o controle do próprio proprietário sobre o tempo de repouso das plantas na primeira extração que foi feita pelo proprietário. 


\subsection{8 - Transporte e Armazenamento}

Tradicionalmente os feixes ou fardos de fibras brutas são chamados de 'mondongos' de piaçava (Figura 21), medem mais de $2 \mathrm{~m}$ de comprimento e pesam aproximadamente $60 \mathrm{~kg}$ a $80 \mathrm{~kg}$. A massa dos fardos é uma forma de mensurar, mas a prática extrativista define o fardo pelo volume e formato, ou seja, conforme o transporte utilizado e o destino dos fardos, esses fardos de fibras brutas são finalizados com determinadas dimensões. Nas áreas de extração não existe balanças, este equipamento é utilizado no momento da compra e venda dos fardos de fibra bruta, limpa e/ou cortadas nos ‘catadouros' familiares ou armazéns.

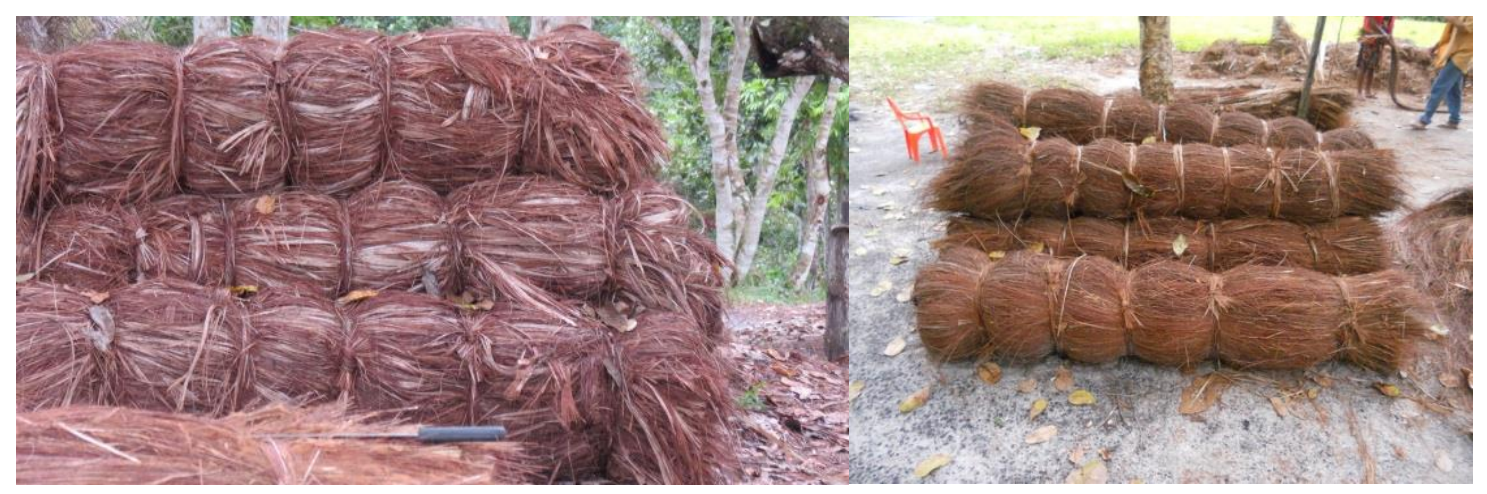

Figura 21: 'Mondongos', feixes ou fardos de fibra bruta e 'mondogos' de fibra limpa.

Os fardos de fibra bruta são feitos na área de extração com a junção das fibras brutas extraídas de várias palmeiras. A cada 'capa' extraída e jogada no chão o extrativista que dá o apoio (Figura 22), vai juntando e esticando, envolvendo os 'tocos' no feixe, quando atinge o volume desejado, faz as dobras e amarra o feixe com as próprias fibras da piaçava.

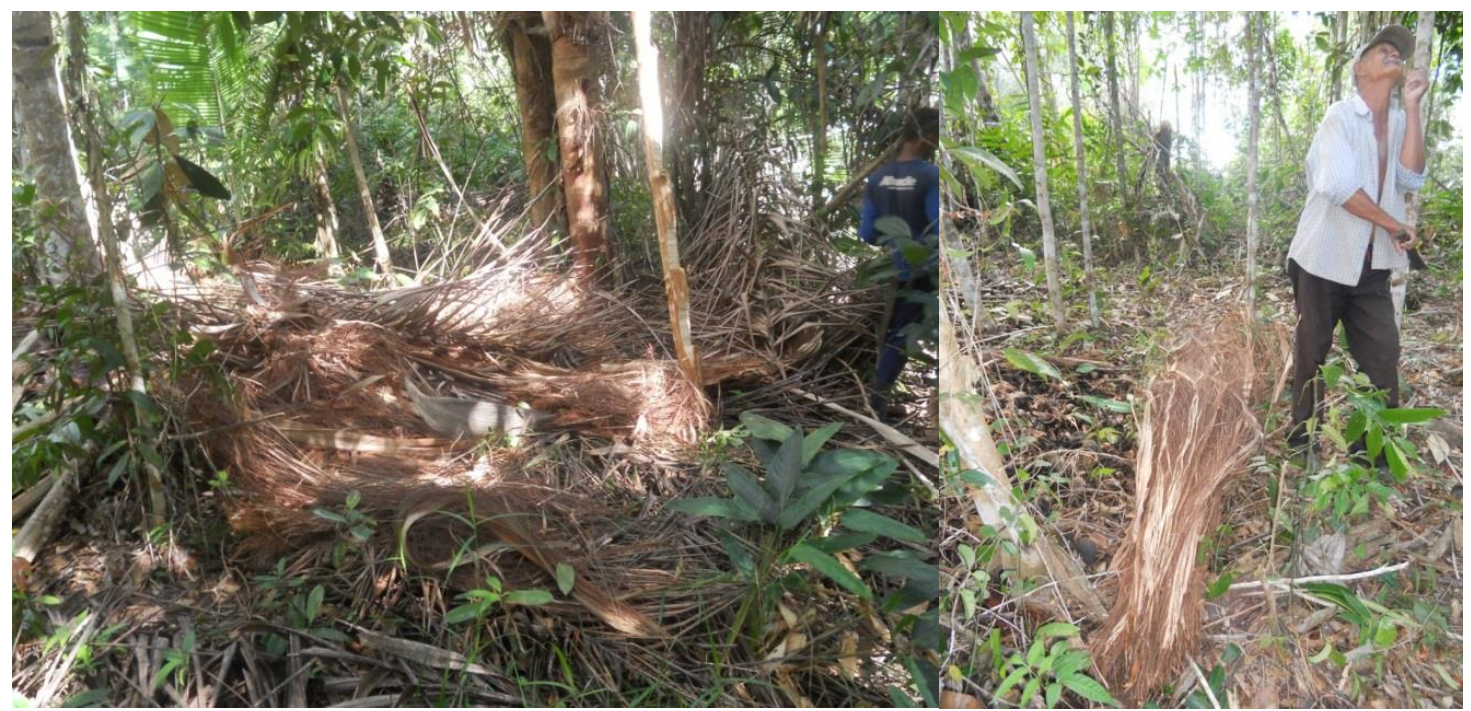

(a)

(b)

Figura 22: Capas de piaçava jogadas no chão pelo extrator (a) e 'capas' esticadas pelo auxiliar para posterior formação dos fardos de fibras brutas (b). 
Em Canavieiras na propriedade particular a prática é de trabalho em conjunto, na área quilombola em Ituberá o 'tirador' trabalhava sozinho nas matas de piaçava. Em ambas as áreas o transporte interno da fibra bruta são realizados por automóveis.

As vias de acesso aos piaçavais (Figura 23) comumente não são pavimentadas, localizam-se entre os talhões dos plantios, próximas às matas de piaçava, fragmentos de Mata Atlântica e são estradas que dão acessos aos sítios, chácaras, fazendas e quilombos até a sede dos municípios baianos.

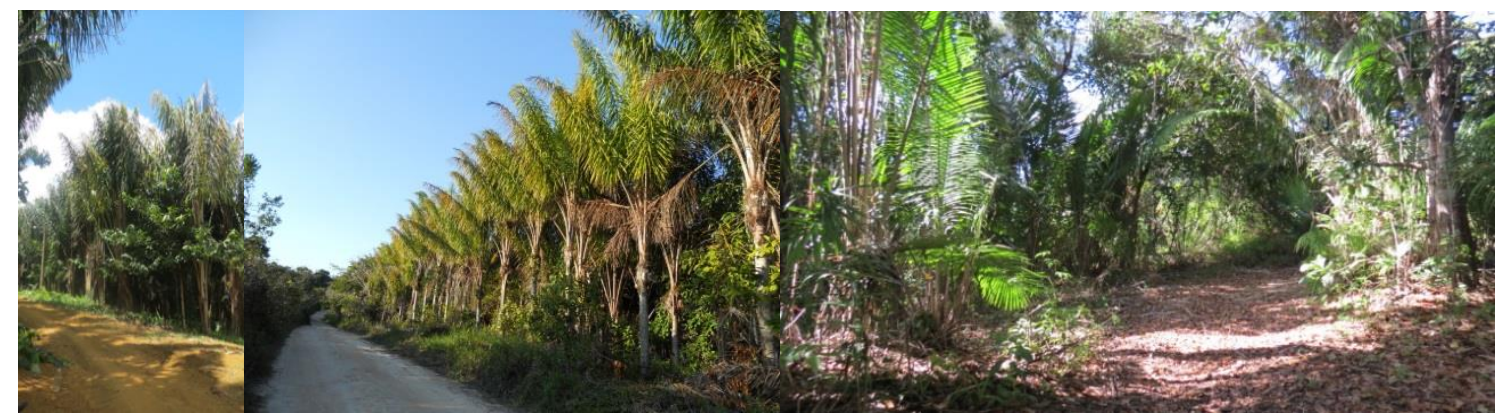

(a)

(b)

(c)

Figura 23: Vias de acesso aos piaçavais: mata de piaçava (a), plantio (b) e vicinais (c).

Dentro dos plantios e matas de piaçavas o transito dos agroextrativistas é feita á pé em trilhas ou mesmo embaixo do sub-bosque dos piaçavais que são bem transitáveis, a dificuldade, neste caso, são as grandes distâncias percorridas dentro dos piaçavais. Juntam algumas 'capas' de fibras brutas, colocam nas costas e armazena-as nas margens das vias de acesso mais próximas, locais onde são feitos os fardos de fibra bruta. Deste ponto em diante os fardos podem ser transportados por animais domésticos, principalmente no lombo dos burros e, em alguns casos, pequenos tratores ou veículos, transportam os fardos para sede da fazenda, galpão ou 'catadouro' familiar (Figura 24).

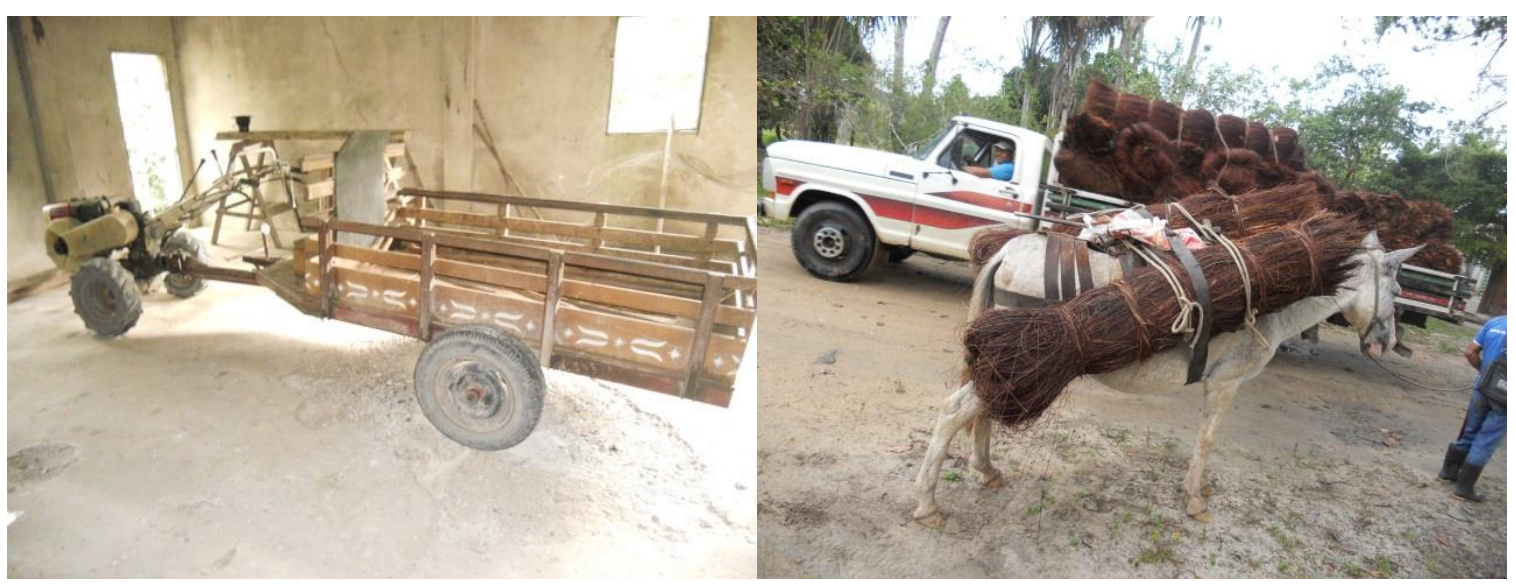

(a) (b)

Figura 24: Veículos utilizados para transporte da fibra vegetal: trator de rabeta (a), jumento e caminhão (b). 
Em áreas de Mata Atlântica onde as palmeiras ocorrem mais espaçadas umas das outras, os agroextrativistas fazem trilhas de acesso até as palmeiras, com conexão entre as plantas e um centro onde fazem a junção das 'capas' extraídas e também realizam o 'amarrio' das fibras brutas, ou seja, a formação dos fardos ou feixes. Nestes locais de 'amarrio' o animal de carga chega pela trilha e leva os fardos até os 'catadouros' familiares. Em alguns casos os agroextrativistas também levam até as vias de acesso onde são transportadas por fretes até os 'catadouros' familiares (Figura 25).

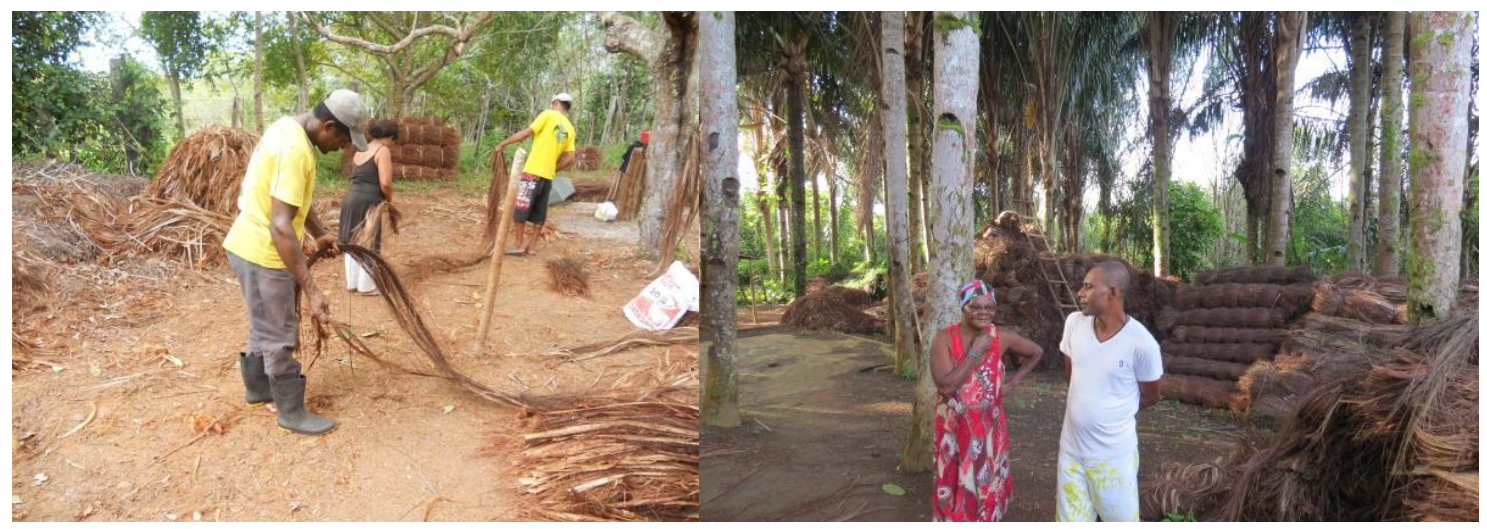

Figura 25: Vista de‘catadouros’ familiares em Canavieiras e Ituberá, respectivamente.

Toda a atividade de manejo florestal da piaçava requer força física do extrativista, principalmente no 'amarrio' (Figura 26) e transporte dos fardos, devido ao tamanho dos volumes formados, além de tomar uma boa parte do tempo do agroextrativista. Sobre essas dificuldades o Sr. Leonardo (Lió) da comunidade de Brejo Grande comenta:

\section{“(...) os antigos criavam cabelos nos ombros de tanto carregar mondongos de piaçava".}

O 'amarrio' é feito com a piaçava bruta e, posteriormente, após a separação e limpeza da fibra e 'fita', as fibras limpas são novamente amarradas em fardos para comercialização com atravessadores.

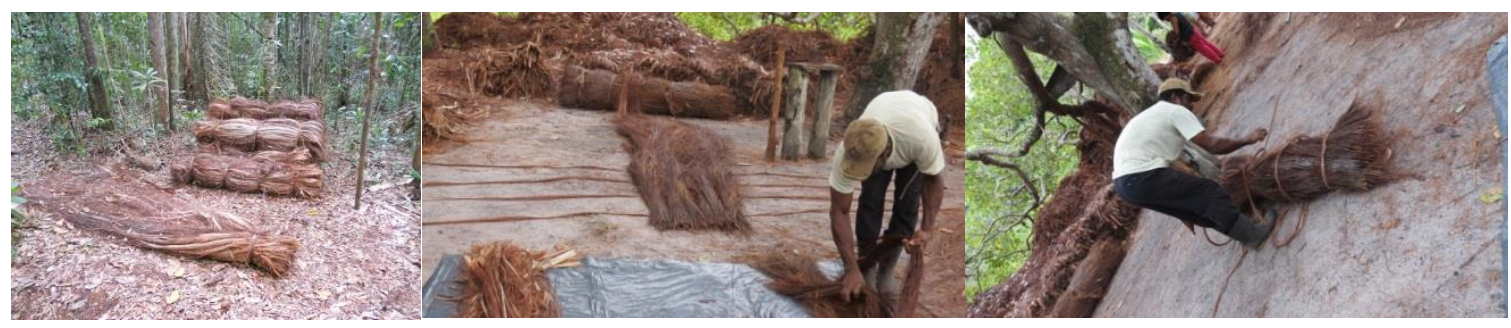

(a) (b) (c)

Figura 26: (a) Fardos e 'cabeças' formados na mata atlântica e (b) 'amarrio da fibra limpa no 'catadouro' e (c) finalização do fardo ('mondongo'). 
Segundo informações dos agroextrativistas e observações de campo, o extrativista leva aproximadamente de 10 a 15 minutos para amarrar um mondongo, considerando um dia de trabalho, um extrativista sozinho consegue amarrar entre 8 a 10 arrobas de piaçava suja.

Em um dia de trabalho na mata o 'tirador' consegue subir na palmeira, realizar a limpeza e extração de duas arrobas $(30 \mathrm{~kg}$ ) de fibras brutas. Alguns 'tiradores' gostam de trabalhar sozinhos, neste caso o 'tirador' sobe em muitas palmeiras, num determinado

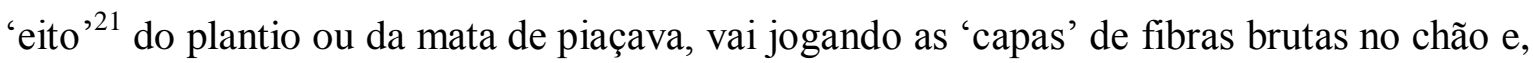
no final do dia ele retorna amarrando as 'cabeças' de fibras brutas e arrastando- as até próximo a via de acesso do plantio ou mata de piaçava. Neste caso um único 'tirador' tem uma produtividade entre duas a três arrobas por dia. Posteriormente ocorre o transporte para os 'catadouros' familiares, galpão/armazém (Figura 27) ou venda das fibras para atravessadores.

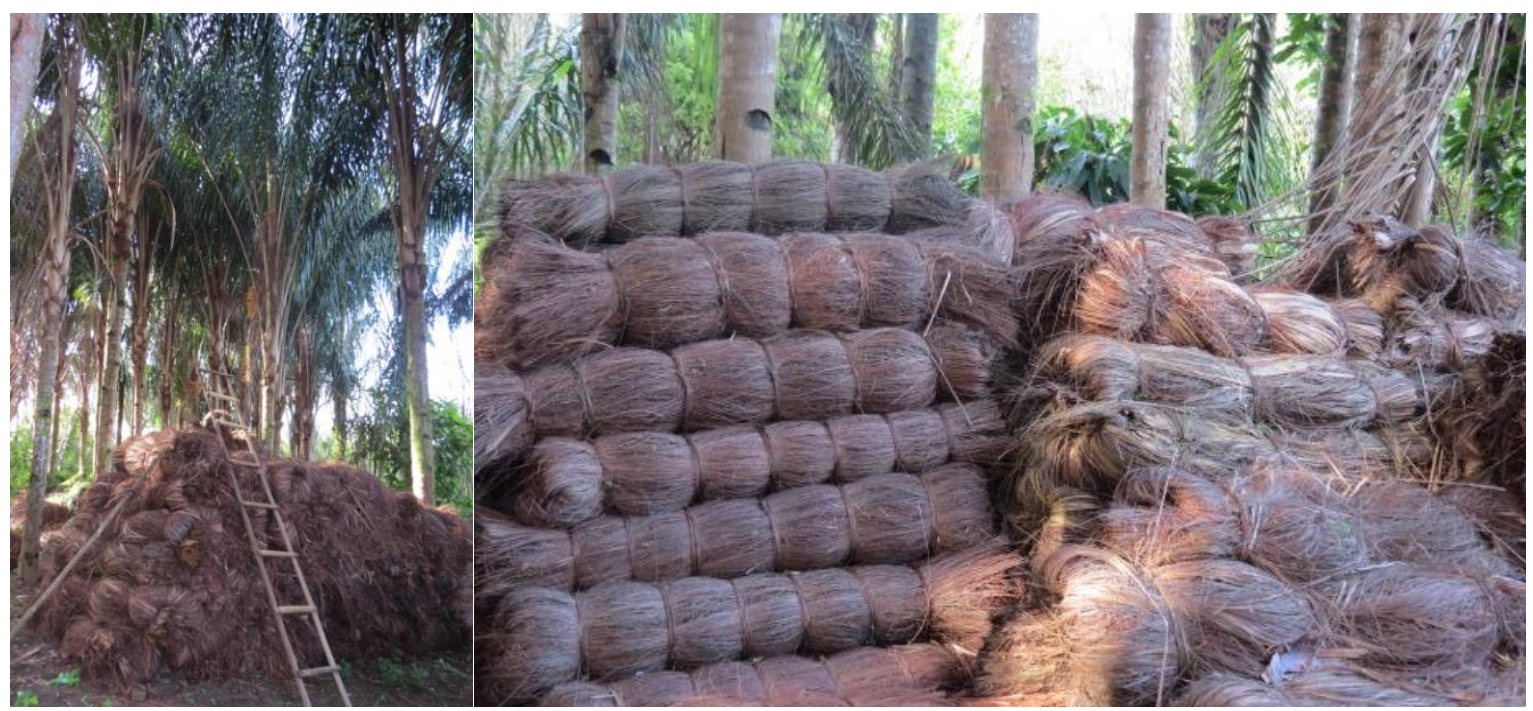

Figura 27: Armazenamento dos feixes de piaçava no 'catadouro' familiar do quilombola André Taraca Assunção, Ituberá, Bahia.

A prática tradicional de comercialização das arrobas de fibras brutas ou limpas de piaçava era deixa-las descansando por um dia no rio e, no dia seguinte repassar ao atravessador. Neste momento fazia-se a pesagem dos fardos de fibra. Os atravessadores, por sua vez, definiam os preços da piaçava molhada inferior aos da piaçava seca. Na região de Canavieiras ainda persiste essa prática de molhar os fardos de piaçava e por isso a

21 'Eito' é uma unidade de trabalho dentro da mata de piaçava ou plantio, destinada a determinado 'tirador'. Esse local é definido no início da extração pelo grupo de 'tiradores', cada um fica com um 'eito' da área de extração. As áreas quilombolas nativas são dividas por 'eitos' de determinada pessoa ou família. Cada 'eito' pertence a uma família, em áreas de mata atlântica o 'eito' são as reboleiras de piaçavas. 
arroba nessa região equivale a $16 \mathrm{~kg}$, em algumas transações comerciais. Já no município de Ituberá e Nilo Peçanha não foi identificado esse tipo de procedimento no manejo das fibras brutas entre os extrativistas consultados. Inclusive para maior durabilidade das fibras, deve-se armazena-las em locais secos, sob estrados de madeira para evitar sua degradação. Na etapa seguinte de pré-beneficiamento e beneficiamento da fibra vegetal, os agroextrativistas afirmam que trabalhar com a piaçava úmida facilita a separação, desembaraço e limpeza das fibras e 'fitas' de piaçava, além de diminuir a poeira. 


\section{6 - CONCLUSÕES E RECOMENDAÇÕES}

A metodologia adotada no inventário das palmeiras de piaçava considerou o saber quilombola e, junto com a comunidade, definiu a área total plantada no quilombo, através do mapa mental ou croqui do território quilombola. Essa metodologia de levantamento do potencial produtivo, mostrou-se eficiente, precisa e barata. $\mathrm{O}$ erro amostral do inventário florestal foi menor no quilombo, e as estimativas extrapoladas nas plantações quilombolas está mais próxima a realidade, do que as estimativas feitas para área particular.

O levantamento também indica que plantios descontínuos, como na área quilombola, aumenta a proteção das plantas contra pragas e doenças, elevando a densidade dos plantios. No quilombo foram estimado 1.250 plantas/ha e na propriedade foi estimada 835 plantas/ha.

As práticas extrativistas de incisões no estipe das palmeiras não se mostraram tão prejudiciais, visto que os plantios quilombolas se apresentaram mais saudáveis quando comparados com a área particular, onde o manejo florestal praticado não permite incisões nos estipes das palmeiras. Ressalta-se que as áreas foram implantadas na mesma época.

Outro fator que está contribuindo com a sanidade dos plantios quilombolas é a diversidade dos mesmos, a ausência de tratos silviculturais após o sombreamento da área plantada, e o desenho descontínuo da produção familiar, onde cada família quilombola tem sua roça e piaçaval, intercaladas por áreas com Mata Atlântica.

A ocorrência de indivíduos mortos e danificados também foi maior em Canavieiras, nas cinco parcelas, contabilizaram-se nove mortos e onze danificados, em Ituberá nas seis parcelas foram encontrados quatro mortos e sete danificados. Na propriedade a média ficou em 1,8 plantas mortas por parcela e 2,2 plantas danificadas por parcela. No quilombo uma média de 0,67 plantas mortas por parcela e 1,17 plantas danificadas por parcela.

Os objetivos da pesquisa foram atingidos com êxito, sugere-se que a metodologia adotada para o levantamento do potencial produtivo da área quilombola seja testadas em novos levantamentos. A produtividade média das plantas no quilombo foi de $3,3 \mathrm{~kg} / \mathrm{planta} /$ ano e a produtividade média da propriedade foi de $1,2 \mathrm{~kg} / \mathrm{planta} / \mathrm{ano}$.

Identificou-se que os plantios de piaçava são bastantes heterogêneos, apresentando altas variações entre parcelas, dentro de parcelas e entre as variáveis mensuradas no inventário florestal. E que as fases de desenvolvimento das palmeiras devem ser adotadas em novos levantamentos. 
Sugere-se a adoção do modelo de produção de fibras brutas (PFB) em função do diâmetro e altura das palmeiras (BP e COQ) para mensurar a produção por planta.

Quanto ao manejo florestal dos frutos observou-se que a coleta dos frutos é feita no chão e embaixo da palmeira o epicarpo e mesocarpo são extraídos dos frutos e esses são ensacados e comercializados pelo milheiro de frutos. O acompanhamento de equipes de extratores em ambas as áreas, as observações de campo e as entrevistas realizadas constataram que, parte dos 'tiradores' não estão respeitando o conhecimento tradicional que preconiza que os frutos e inflorescências das piaçavas devem permanecer nas palmeiras após a extração da fibra vegetal. Fato bastante lembrado pelos 'tiradores' profissionais mais idosos, principalmente os quilombolas da região de Ituberá. Deve-se monitorar a regeneração e mortalidade da palmeira.

A média de fruto por planta nas parcelas de Canavieiras (outubro, 2013) foi de 3,4 plantas com fruto e 9,2 plantas com inflorescência por parcela. Em Ituberá (janeiro, 2014) foi encontrado a média de 5,2 plantas com fruto e 8,2 plantas com inflorescência por parcela. Observa-se um aumento da quantidade de plantas com fruto em detrimento a quantidade de plantas com inflorescência, fato que pode estar relacionado à época da realização do levantamento. 
CAPÍTULO 2 - PROCESSAMENTO DA FIBRA VEGETAL E FRUTO DA PIAÇAVA (Attalea funifera Mart.) DA BAHIA 


\section{1 - INTRODUÇÃO}

A fibra vegetal extraída da palmeira Attalea funifera Mart. é o principal PFNM que essa espécie fornece às pessoas. Por ser uma planta endêmica da Bahia, com ocorrência restrita, é conhecida popularmente como a piaçava da Bahia, inclusive para diferencia-la da piaçava do Amazonas (Leopoldina piassaba) e piaçava do Acre (Aphandra natalia).

A fibra vegetal era utilizada pelos índios, principalmente pelas etnias Tupinambá e Tupiniquim que residiam nas áreas de ocorrência natural da espécie. Os portugueses se apropeiaram deste conhecimento tradicional associado à espécie vegetal e iniciaram o aproveitamento da fibra vegetal para fazer cordas de navios, entre outros produtos com a fibra vegetal.

Os índios praticavam o uso integral, ou uso multiplo da palmeira de piaçava da Bahia, esses compartilharam o conhecimento tradicional com os negros encarregados de fazer a exploração econômica da fibra vegetal a mando dos senhores de engenho, durante a escravidão. Após a libertação dos negros, esses se organizaram em núcleos familiares, em regiões de difícil acesso, nas matas da Bahia, formando comunidades que hoje são reconhecidas como comunidades quilombolas.

Os relatos dos extrativistas negros, remetem ao aproveitamento integral da piaçava da Bahia, como uma estratégia de sobrevivência nas áreas com Mata Atlântica, além da fibra vegetal, utilizavam as folhas para cobertura de casas e confecção de objetos como esteiras, os frutos e o palmito para alimentação humana.

Os negros conservaram a atividade econômica em torno da exploração da fibra vegetal até os dias atuais, substituindo o senhor do engenho pelos atravessadores, que também detinham e, ainda detém, o monopólio do mercado consumidor da fibra vegetal. Os negros dominavam e, ainda dominam, a etapa de extração da fibra vegetal, o prébeneficiamento da fibra vegetal e, aqueles que possuem territórios, com estoque da matéria prima, podem auferir melhores ganhos com esse PFNM. Infelizmente observa-se que as mudanças nas relações de trabalho, do período colonial aos dias atuais, dentro da cadeia produtiva, são poucas.

Por muito tempo a região Sul da Bahia foi fornecedora de matéria prima para as fabricas de vassouras localizadas nos estados de São Paulo, Rio de Janeiro, Espírito Santo e Minas Gerais, em menor proporção também fornece para cidade de Feira de Santana no proprio estado da Bahia. O montante exportado também segue de forma pré-beneficiada para países como Holanda, Alemanha, Portugal e Inglaterra. 
O aproveitamento integral da palmeira de piaçava é uma das alternativas de renda que deve ser aprimorada tendo em vista a versatilidade desta espécie florestal. De uma planta na fase de desenvolvimento COQ pode-se obter: fibras vegetais, manta vegetal ('fita'), polpa ('satim'), endocarpo (biojóias), sementes (óleo vegetal) e folhas (artesanatos). O único PFNM com aniquilamento da palmeira é o palmito, fato que impossibilita a extração e o aproveitamento dos demais produtos. A palmeira é uma espécie importante na manutenção da fauna silvestre que em troca realiza a propagação dos frutos pelas matas da região. Essa palmeira também tem potencial para utilização como paisagismo, por ser alta.

A 'fita' é um subproduto do pré-beneficiamento da fibra vegetal do qual se faz os 'pentes' para cobertura de quiosques. A polpa do fruto é utilizada no prato tradicional quilombola, conhecido localmente por 'satim'. O endocarpo ósseo é utilizado para fazer biojóias. A semente é consumida pelos agroextrativistas em seus trabalhos pela mata, tem potencial para extração do óleo vegetal e é o embrião de uma nova palmeira. As folhas são utilizadas para coberturas de paióis dos animais domésticos e confecção de artesanatos.

O domínio das técnicas de confecção de vassouras da fibra vegetal, por parte dos agroextrativistas locais, ocorreu inicialmente por empresas de 'fundo de quintal' que trabalhavam e, ainda trabalham, informalmente na cidade de Feira de Santana, entre outras cidades nordestinas, abastecendo o comércio local com as vassouras de piaçava. Com o passar dos anos algumas empresas formalizaram o negócio, mas até hoje o que se observa é uma gama de pessoas produzindo informalmente vassouras de piaçava redondas (tradicional), esse é o tipo de vassoura preferida dos consumidores das cidades baianas, consumidores de baixa renda, quilombolas, indígenas e agroextrativistas.

Nas redes de supermercados das cidades como Salvador, entre outras capitais nordestinas e no sudeste brasileiro, a preferencia é pela vassoura de chita com cepo de madeira ou plástico com dezoito furos. Adequada para uso domestico, interno e externo das residências. Empresas de limpeza urbana utilizam vassourões com 30 a 40 furos e cepo de madeira. Essas últimas também são utilizadas para limpezas de pátio de empresas e fezes de gado nos currais das fazendas nordestinas.

Após a instalação de cooperativas na região de Nilo Peçanha e Ituberá e, a organização dos agroextrativistas e quilombolas em associações locais e devidas adequações legais para acessar a subvenção do governo federal, nos anos de 2011 e 2012, observou-se, o domínio das etapas de confecção das vassouras por parte dos agroextrativistas e quilombolas da região. 
Em 2013, após mais de 500 anos de exploração da fibra vegetal da piaçava da Bahia, o Quilombo Brejo Grande, localizado na zona rural do município de Ituberá, passa a produzir vassouras de fibra da piaçava, ou seja, o primeiro quilombo da Bahia e do Brasil a conseguir dominar todas as etapas de produção até o produto final, vassouras e artesanatos para venda direta ao consumidor.

As etapas do aproveitamento da fibra vegetal da piaçava, neste estudo, podem ser resumidas em manejo florestal, pré-beneficiamento, beneficiamento e confecção das vassouras de piaçava. Em cada etapa dessas, atualmente, as atividades são realizadas por diferentes profissionais entre extrativistas, atravessadores, operadores e empresários, provocando a dispersão dos ganhos de ator da cadeia produtiva, aumentando as perdas da matéria prima e aumentando os custos com transporte e armazenamento dos produtos de cada etapa do processo produtivo.

Em uma região com disponibilidade deste recurso e, com populações negras e índios que dominam o aproveitamento integral da piaçava, estratégias de desenvolvimento de modelos onde esses extrativistas possam auferir mais ganhos, são urgentes.

Diante desta realidade, este trabalho apresenta informações inéditas sobre processamento dos PFNMs oriundos das fibras vegetais em uma análise integrada. Para tanto detalha as etapas de processamento da fibra vegetal da piaçava, apresenta coeficientes técnicos de aproveitamento da fibra vegetal bruta até a confecção de vassouras de piaçava, bem como produtividade por dia, por pessoa e as possiveis rendas extrativistas no beneficiamento e comercailização dos PFNMs oriundos das fibras vegetais.

Disponibiliza informações preliminares sobre o aproveitamento dos frutos da piaçava, indica principalmente sugestões de metodologias para aferiguar rendimentos de epicarpo, mesocarpo, endocarpo, sementes e oleo vegetal da piaçava.

Os frutos da piaçava são aproveitados na elaboração de uma comida tradicional chamada 'satim'. Não se identificou nenhum trabalho científico, relatórios, publicações na mídia em que esse processo foi descrito. Atualmente esse alimento é pouco consumido entre as comunidades quilombolas e somente as pessoas mais velhas dominam as técnicas de preparo, fato que dificulta a descrição e documentação desse fazer tradicional. Para o preparo do 'satim' é utilizada a polpa do fruto da piaçava, mais especificamente o mesocarpo do fruto.

As sementes dos frutos são consumidas in natura pelas crianças e 'piaçaveiros' em suas andanças pela mata quando a fome aperta. Neste caso parte-se o fruto com o facão e retira-se uma ou duas sementes, amêndoas, da piaçava. As sementes 'de vez' presenta-se 
mais macias, sendo mais agradável ao consumo. Quando a semente está madura é mais rica em óleo vegetal e, portanto é utilizada para esse fim.

Acredita-se que o conhecimento do estado da arte do processamento, atual, desta fibra vegetal é fundamental par se iniciar a mudança necessária e desejada pelas populações tradicionais e pelo poder publico, quando promove ações para cumprir sua função socioambiental. Para criar novos modelos produtivos que realmente afetem a qualidade de vida de comunidades tradicionais como as indígenas, quilombolas, pescadores, entre outras, que vivem nas áreas de ocorrência natural da Attalea funifera no Bioma Mata Atlântica, é necessário conhecer a realidade produtiva desses extrativistas da piaçava da Bahia. Novos produtos, tecnologias e técnicas devem ser desenvolvidos junto com essas comunidades, em um diálogo próximo e constante, com vistas à inovação.

Este capítulo exibe as técnicas e tecnologias envolvidas no processamento da fibra vegetal da piaçava, apresenta resultados dos ensaios de rendimento em fibra vegetal aproveitável para confecção de vassouras de piaçava, em sistemas produtivos distintos. Os resultados são decorrentes da pesquisa-ação, dos diálogos e trocas de saberes realizadas, intervenções realizadas nos anos de 2012 a 2015 que qualificam as informações e imprimem uma característica mais realista a este trabalho de pesquisa cientifica e aplicada. As entrevistas aos atores chaves e realização de experimentos em campo fornece uma gama de dados quantitativos, úteis aos extrativistas tradicionais e, demais produtores que trabalham com a piaçava da Bahia, além de contribuir com informações inéditas no meio formal do conhecimento.

\subsection{1 - Hipótese}

O domínio das etapas de produção por parte dos extrativistas, bem como a diminuição das perdas e aproveitamento dos resíduos ao longo da cadeia produtiva, gera ganhos financeiros aos extrativistas da piaçava da Bahia.

\section{2 - OBJETIVOS}

Analisar, mensurar e determinar os coeficientes técnicos do processamento da fibra vegetal da Attalea funifera Mart., bem como demais PFNMs da espécie, processamento praticados pelas comunidades agroextrativistas e quilombolas. 


\subsection{1 - Objetivos Específicos}

(a) Disponibilizar dados técnicos e informações dos produtos não madeireiros oriundos da Attalea funifera Mart;

(b) Mensurar as perdas em todas as etapas da cadeia produtiva da piaçava, desde a extração da fibra vegetal até a confecção da vassoura de piaçava;

(c) Indicar o rendimento em vassouras de cada arroba de fibra suja, tempo gasto em cada etapa do processo produtivo;

(d) Com as informações geradas na pesquisa, mensurar a renda aproximada dos extrativistas da piaçava no modelo atual e no cenário onde o extrativista domina todas as etapas de prosução;

(d) Apontar rendimento em polpa do fruto da piaçava; e

(e) Indicar rendimento em óleo vegetal das sementes da piaçava.

\section{3 - REVISÃO DE LITERATURA}

Estima-se que entre 4.000 e 6.000 espécies de plantas não madeireiras tenham importância comercial em todo o mundo, destas, algumas têm grandes mercados de exportação e as condições ecológicas e sociopolíticas adequadas para certificação. Na Índia, 95\% das 400 espécies de plantas usadas pela indústria indiana de ervas provêm de áreas nativas. $\mathrm{Na}$ Alemanha, 93\% a 98\% das mais de 1.500 plantas medicinais comercializadas são extraídas de populações vegetais silvestres (IQBAL; 1993).

Segundo a ITTO (1998), os esforços requeridos para viabilizar e obter sucesso na comercialização de produtos florestais não madeireiros seria: maiores informações econômica e estatística; buscar mercados mundiais; identificar o potencial de suprimento e padrão de qualidade destes produtos; desenvolver tecnologias de estocagem e transformação; desenvolver regulamentos de manejo e estudos de custos para os mesmos; buscar marketing adequado; e criar conceito de comercialização conjunta de vários produtos ao mesmo tempo, buscando o mesmo canal de comercialização.

A comercialização dos PFNMs no Brasil ocorre principalmente nos mercados locais das cidades, próximo aos locais de coleta, apanha ou extração do produto. Há oferta 
de muitas plantas medicinais, cascas, raízes, folhas, exsudatos ${ }^{22}$, garrafadas com a mistura de ervas, mas também muitas frutas, sementes, castanhas, fibras vegetais, ceras e artesanatos criados com as mais variadas partes das plantas. Normalmente esses produtos são apresentados in natura, embalados e com pouca ou nenhuma informação em rótulos.

Os alimentos que sofrem processamento como polpas, licores, biscoitos, compotas, sabonetes, cosméticos e medicamentos que utilizam plantas medicinais como principio ativo, comumente são comercializados em supermercados, farmácias, entreposto de produtos naturais. Diante deste contexto, observa-se que o processamento dos PFNMs brasileiros necessita de uma atenção especial, tanto no que concerne às tecnologias necessárias para elaboração de produtos que mantenham suas propriedades medicinais (nutitivas), quanto às técnicas e tecnologis que envolvem às questões fitosanitárias e segurança para o consumidor final. É primordial que está tecnologia seja elaborada em conjunto com as comunidades, que seja apropriada aos modelos de produção familiar, onde os extrativistas consigam dominar o processaento (beneficiamento) e que os novos produtos supram necessidades reais do mercado consumidor local, regional, nacional e internacional.

Agregar valor a produtos advindos da sociobiodiversidade, valoriza modos de vida e conhecimentos intrínsecos à natureza local, permitindo a manutenção, para além da mera sobrevivência, de grupos sociais e suas relações com o meio ambiente físico e cultural (SIMONI, 2010).

Tecnologia é um corpo de conhecimentos de diferentes tipos, científicos e outros, que pode ser empregado em qualquer ramo ou atividade. É um conhecimento aplicado na concepção, na produção e na distribuição de bens e serviços. É um meio e não um fim em si mesmo (BARBIERI; ÁLVARES, 2003).

Frank (2005) afirmou que o conhecimento dos mecanismos de funcionamento dos sistemas produtivos, desde a produção até a comercialização, necessita ser compreendido em maior profundidade, principalmente no tocante aos aspectos relacionados às tecnologias adotadas e aos processos internos à produção e organização. Coloca que as inovações, em seu estudo, são entendidas como as melhorias que acrescentam novidades e aperfeiçoamentos de pequena monta em produtos, processos e serviços.

\footnotetext{
${ }^{22}$ Todas as substâncias que saem dos caules, galhos, pecíolos ou folhas das plantas, após algum ferimento provocado pelo homem ou não. Exemplo são as resinas de breu, amescla de cheiro, sangue de draco, látex, a seiva de jatobá, as bolsas de óleo da copaíba, entre outros.
} 
Tecnologia Social (TS) incorpora a ideia de que existe um processo de inovação interativo em que o ator diretamente envolvido com essa função inovativa contém (ou conhece) ao mesmo tempo, por assim dizer, tanto a "oferta" quanto a "demanda" da tecnologia. Portanto, a inovação tecnológica - e por extensão a TS - não pode ser pensada como algo que é feito num lugar e utilizado em outro, mas como um processo desenvolvido no lugar onde essa tecnologia vai ser utilizada pelos atores que vão utiliza-la (DAGNINO; BRANDÃO; NOVAES; 2004).

O beneficiamento de PFNM pode ser entendido como o conjunto de tratamentos dados à matéria prima (PFNM bruto) até se chegar ao produto final. Estes podem ser produtos in natura e os produtos transformados (modificados) que sofrem alterações em suas propriedades químicas e/ou físicas. Na etapa do beneficiamento de PFNM existe a necessidade de pesquisas que permitam a realização de ajustes tecnológicos aos diferentes tipos de unidades de beneficiamento, visando o estabelecimento de pacotes tecnológicos básicos que possibilitem uma maior eficiência na produção, diminuição de custos e melhoria da qualidade do produto final. $\mathrm{O}$ beneficiamento contribui para diminuição da perecibilidade e diminuição dos volumes/pesos dos produtos, facilitando o armazenamento e transporte aos centros urbanos (MACHADO, 2008).

Tão importante quanto à visão de todas as etapas do processo produtivo é o conhecimento do arranjo produtivo local como está organizado, ou seja, quem, onde e por quanto os concorrentes adquirem seus produtos para o beneficiamento, quais os canais de comercialização existentes para o seu produto final, onde estão os gargalos ou pontos de estrangulamento da atividade produtiva como um todo. A atividade extrativista de determinado PFNM será mais intensas nas áreas com povoamentos naturais da espécie explorada, consequentemente configurando um arranjo natural entre os produtores do bioma (PIMENTEL; 2008).

O Plano Nacional da Sociobiodiversidade (MMA) conceitua o Arranjo Produtivo Local - APL como um agrupamento de empreendimentos de um mesmo ramo, localizados em um mesmo território, que mantêm algum nível de articulação, interação, cooperação e aprendizagem entre si e com os demais atores locais - governo, pesquisa, ensino, instituições de crédito (PNSB, 2008). Segundo Diniz (2008) os Sistemas Produtivos Locais - SPL são aglomerações de agentes de diferentes naturezas, localizados num mesmo território, com ações consistentes de articulação, interação, cooperação e aprendizagem. Relações de cooperação entre atores diferentes com o objetivo comum de discutir junto em um setor onde são especialistas. 
Segundo Pimentel; Matias (2004) a metodologia de Plataformas Tecnológicas em Arranjos Produtivos ou Cadeias Produtivas, tem se mostrado um instrumento eficaz. Tratase de uma abordagem sistêmica que une o planejamento e as ações estratégicas, sendo ao mesmo tempo um processo de mobilização, envolvimento e negociação entre todos os atores participantes. Os autores exemplificam o ocorrido com o Arranjo Produtivo de Fitoterápicos e Fitocosmésticos em Manaus/AM. Inicialmente o arranjo foi dividido em quatro grupos temáticos, procurando abarcar as principais etapas: obtenção de matériaprima vegetal; processamento inicial; processamento produtivo; e mercado. Em seguida foram identificados os gargalos tecnológicos e não tecnológicos, bem como as ações possíveis de execução para obter suas soluções. Das análises dos gargalos tecnológicos foram derivadas as oportunidades de projetos cooperativos, que em seguida seriam desenvolvidos por entidades de pesquisas em conjunto com os demais atores e, principalmente, com empresas e comunidades.

Segundo Souza; Vicente (2003) a cadeia produtiva consiste em acompanhar todos os passos do processo produtivo, desde o manejo até a comercialização, evitando que o fracasso de uma das etapas da cadeia impeça o êxito da atividade como um todo. Observase que as atividades de campo devem considerar a técnica de colheita de menor impacto, armazenagem adequada, tempo de espera do transporte, procedimentos diferenciados para cada espécie explorada. As fases de beneficiamento e industrialização devem obedecer a normas de higiene e produção, de acordo com o tipo de produto, alimentício, limpeza, fitoterápicos, cosméticos, entre outros. A fase de comercialização deve descobrir nichos de mercado, definir a demanda destes e se comunicar com as duas fases anteriores para organização da produção conforme a demanda. Outro risco de insucesso no manejo das espécies florestais não madeireiras é não incorporar dentro do conceito de cadeia produtiva a etapa de manejo e a aquisição do produto nas áreas nativas remanescentes, em plantios adensados, em sistemas agroflorestais, em cultivos homogêneos das espécies potenciais entre outras formas de estoque do recurso natural. Portanto o controle da qualidade e as análises do processo produtivo deve considerar a etapa de manejo da espécie em campo, a fim de garantir a qualidade do produto final apresentado.

Segundo o Manual de Value Link (GTZ, 2008), cadeia de valor é um conjunto de empresas (operadores) que desempenham atividades comerciais relacionadas (funções). São produtores, processadores, comerciantes e distribuidores de um produto particular. As empresas são ligadas por uma série das transações comerciais em que o produto é passado 
de produtores primários aos consumidores finais. De acordo com a sequência de funções e de operadores, as cadeias de valor consistem em uma série elos da cadeia (ou estágios).

A produção agroextrativista depende, em larga medida, da oferta natural dos recursos, que oferece uma dinâmica sazonal. Muitas comunidades rurais se veem embaraçadas com esse dado, face ao desafio de manter uma cadeia produtiva em fluxo constante, para que seja também regular a sua comercialização. As indústrias mantêm esse fluxo por meio da especialização e massificação (ou ganho de escala), desde o plantio, com a implantação de extensas áreas de monoculturas, um processo mecanizado de beneficiamento e uma larga estocagem baseada na adição de conservantes químicos em seus produtos finais. A realidade do pequeno produtor é bem distinta, pois é na diversidade de produtos que ele encontra uma base econômica segura. Além disso, o manejo artesanal e a substituição de insumos químicos por orgânicos são diferenciais que podem atribuir valor agregado aos seus produtos. A lógica de escala e especialização das indústrias é, nesse sentido, contrária ao modelo diversificado e multifuncional ${ }^{23}$ da pequena produção (NOGUEIRA; 2005).

Segundo Clement et al. (2005) no seu estudo sobre o potencial das palmeiras no Brasil, afirma que o que foi (e é) bom para os povos indígenas e tradicionais, não terá necessariamente uma demanda no mercado atual. Também ressalta que para entrar num mercado altamente competitivo, exige um produto diferenciado, pois concorrer com um produto muito similar exige competência de alto nível. O conhecimento detalhado da cadeia de produção contribui para um projeto bem desenhado, com escala de produção apropriada para o mercado. Ainda segundo os autores, as instituições envolvidas precisam garantir a continuidade necessária para desenvolver um produto novo em uma, duas ou três décadas, afirmam que essa situação é raríssima na América Latina.

\subsection{1 - Fibra Vegetal da Piaçava}

As fibras vegetais, comercializadas no mundo, podem ser agrupadas da seguinte forma: sementes (ex. algodão); líber (juta, linho, cânhamo, crotalária, papoula-de-São Francisco e guaxima); folha (sisal, piaçava, caroá, abacá, henequém, cantala, formio, istle e pita); fruto (coco e paina); raiz (zacatão). Destas, algodão, juta, linho, sisal, abacá, cânhamo e henequém são as de maior significação econômica. Excetuando-se a fibra de

$23 \mathrm{O}$ conceito de multifuncionalidade é de origem francesa e diz respeito à conjugação da produção, identidade cultural e conservação do meio ambiente que se estabelece na produção rural de base familiar. 
coco, que constitui um subproduto da produção de fruto de coco, e as fibras de caroá e piaçava, que são extraídas de áreas nativas, as demais são originarias de plantas cultivadas (MEDINA; 1959 apud AQUINO; 2003).

A utilização das fibras vegetais vem sendo estimulada por serem biodegradáveis, representarem recursos renováveis, não são abrasivas (menor abrasividade aos equipamentos), apresentam baixa densidade, boa flexibilidade no processamento e podem ser facilmente modificadas pela presença de agentes químicos. Porém também não apresentam propriedades uniformes, exibindo uma grande variação nos vetores de suas propriedades, as quais estão diretamente relacionadas com a composição dos seus constituintes celulose e lignina, conforme Aquino (2003). A autora ressalta que as fibras naturais também não apresentam boa estabilidade dimensional devido à absorção de umidade, não exibem termoplasticidade, têm baixa temperatura de processamento e são incompatíveis com os termoplásticos mais comuns.

As principais fibras vegetais Brasileiras em volume de produção, aquelas apontadas pelo IBGE (2013), são as fibras de piaçava, carnaúba e buriti. O principal PFNM da carnaúba é a cera extraída de suas folhas, mas a planta também fornece fibra vegetal e, entre as três espécies, foi a única que teve aumento na quantidade produzida entre os anos de 2012 e 2013, um aumento de 39\%, enquanto a piaçava e o buriti, tiveram decréscimo, $22 \%$ e o $0,6 \%$, respectivamente. Conforme já mencionado a piaçava continua se destacando quanto à quantidade produzida anualmente, mesmo quando comparamos com esses outros PFNMs fornecedores de fibras vegetais: piaçava 44.617 toneladas; carnaúba 2.317 toneladas; e buriti 466 toneladas.

As fibras da Attalea funifera são extremamente resistentes, duradoras e são aproveitadas em uma diversidade de usos. Durante muito tempo foi utilizada exclusivamente para amarras (cordas reforçadas para navios), devido a sua flexibilidade e à alta resistência à salinidade. Atualmente sua importância econômica tem aumentado interna e externamente pelo uso da fibra natural para fins industriais e artesanais, através da fabricação de vassouras para uso doméstico, limpeza urbana, manual ou mecânica, equipamentos para varrer neve e enchimento de estofados de carros (COSTA; 1998).

Os trabalhos encontrados na literatura sobre fibras vegetais da piaçava estão relacionados com o uso dos resíduos das fabricas de vassouras de piaçava na fabricação de 
$\operatorname{compósitos~}^{24}$ poliméricos para substituição de fibras sintéticas (fibra de vidro, carbono, etc.) em diversos campos de aplicação tais como, componentes eletrônicos, peças automotivas, aeronáuticas e aeroespaciaias, eletrodomesticos entre outros (AQUINO, 2003; D'ALMEIDA et al., 2006; NASCIMENTO, 2009; MONTEIRO et al., 2009; MIRANDA et al., 2012).

As fibras vegetais da piaçava da Bahia são principalmente constituídas de células formadas por microfibrilas cristalinas que são constituídas por celulose e uma matriz amorfa de lignina e celulose (THOMAS, 2010).

Essas fibras também são conhecidas por fibras lignocelulosica com comprimento muitas vezes superior a largura, por isso o termo fibra vegetal tem sido usado para designar uma grande variedade de tipos de células que se caracterizam pela forma alongada e parede secundária espessa (YOUNG; 1997). O autor classifica a fibra de piaçava como sendo fibras intraxilares, ou seja, aquelas que são partes integrantes do xilema ou lenho, oriundas de plantas monocotiledôneas, com feixes fibro-vasculares das folhas. A função destes feixes é dar resistência e rigidez à folha e servir de sustentação aos vasos condutores de seiva.

A fibra da piaçava da Bahia é resistente, rígida, lisa, de textura impermeável, variando na cor de marrom claro a marrom vermelho escuro e, na forma, desde cerca de 5 mm de diâmetro, na base, até a espessura de um fio de cabelo na extremidade superior, tendo em média 1,1 $\mathrm{mm}$ de espessura e alcançando 3,5 metros de comprimento. Além disso, conservam sua elasticidade quando umedecidas (AQUINO, 2003). Fornari; Fornari Junior (2013) afirma que a fibra apresenta resistência ao desgaste e às intempéries, baixo peso, elevado comprimento, fato que propicia explorar ao máximo sua propriedade de tração.

Os valores de resistência mecânica e módulos de elasticidade são superiores à fibra do coco e inferiores a fibra de juta e sisal (AQUINO, 2003). As propriedades mecânicas da fibra vegetal da piaçava são: módulo de resistência a tração $143 \mathrm{MPa}$; módulo de elasticidade 5,60 GPa; deformação a ruptura 5,9\%; massa especifica 1,05g/ $\mathrm{cm}^{3}$, conforme Neto; Padine (2006).

A composição química da fibra vegetal da piaçava é rica em lignina $(48,4 \%)$ o que lhe confere impermeabilidade e rigidez, quando comparada com as fibras da juta (16\% de lignina) e sisal (10\% de lignina) e menores teores de celulose: $31,6 \%$ de celulose na

\footnotetext{
${ }^{24}$ Compósitos são materiais compostos estruturais fabricados a partir da mistura de dois ou mais tipos de materiais diferentes e com propriedades mecânicas iguais ou melhores que as dos materiais considerados isoladamente
} 
piaçava; e $60 \%$ de celulose nas fibras da juta e sisal. A temperatura de inicio da decomposição térmica e degradação das fibras de piaçava através do método de análise termogravimétrica (TGA) foram de $225^{\circ} \mathrm{C}$, neste caso a fibra de juta apresenta uma temperatura de decomposição térmica $282^{\circ} \mathrm{C}$ e o sisal $302^{\circ} \mathrm{C}$, valores superiores à fibra vegetal de piaçava. Essas características fazem da fibra de piaçava um material promissor para a utilização como reforço em compósitos poliméricos (AQUINO, 2003)

Avelar (2008) testou a utilização dos resíduos de confecção das vassouras de piaçava na preparação de carvões ativados, concluiu que os resíduos de fibra vegetal são bons percursores de carvões ativados, apresentando alto rendimento. Os carvões ativados quimicamente tiveram maior rendimento que os ativados fisicamente.

Souza (2012) avaliou a resistência mecânica de argamassas leves produzidas por meio da incorporação de resíduos industriais de EVA (Etileno-Acetato de Vinila) e de fibras curtas de piaçava, servindo como reforço para a matriz cimentícia. Os resultados apontaram que o aumento da temperatura de cura residual fez reduzir as resistências à compressão e tração na flexão.

Fornari; Fornari Junior (2013) utilizaram as fibras longas de piaçava em poliéster insaturado, concluíram que a força de atração entre a fibra longa de piaçava e a resina poliéster ortoftálica tem uma relação linear com a área de contato entre a fibra e o polímero, até um valor crítico de aproximadamente $67 \mathrm{~mm}^{2}$.

Bezerra (2014) utilizou os resíduos do pré-beneficiamento em mistura com cimento Portland para produção de painéis compósitos e concluiu que a fibra de piaçava apresenta boa compatibilidade com o cimento, exercendo influência quase nula sobre a reação de hidratação.

Interessados, especialistas e pesquisadores vêm apontando outros usos para os resíduos do processo de produção da vassoura de piaçava, como compostos de borracha, substrato para floricultura tropical (em substituição ao xaxim), a fibra vegetal também tem potencial para ser utilizada na composição de aglomerados para isolantes térmicos, espuma na indústria automotiva e na extração de substâncias químicas da fibra para a área de biomédica, como membranas de permeabilidade seletiva na extração de polímeros (SILVA; GUIMARÃES, 2006). 
Experimentos realizados na sede da Casa Familiar Agroflorestal (CFAF) ${ }^{25}$ em Nilo Peçanha, testaram o uso dos resíduos para confecção de tubetes para produção de mudas de euliptus. O trabalho foi realizado em parceria com a Universidade Federal do Recôncavo da Bahia (UFRB), não concluído e portanto não foi publicado, mas a aparência dos tubetes apontam para um aprimoramento na aderência das fibras residuais, conforme ilustrado na Figura 28 (comunicação pessoal, 2013) .

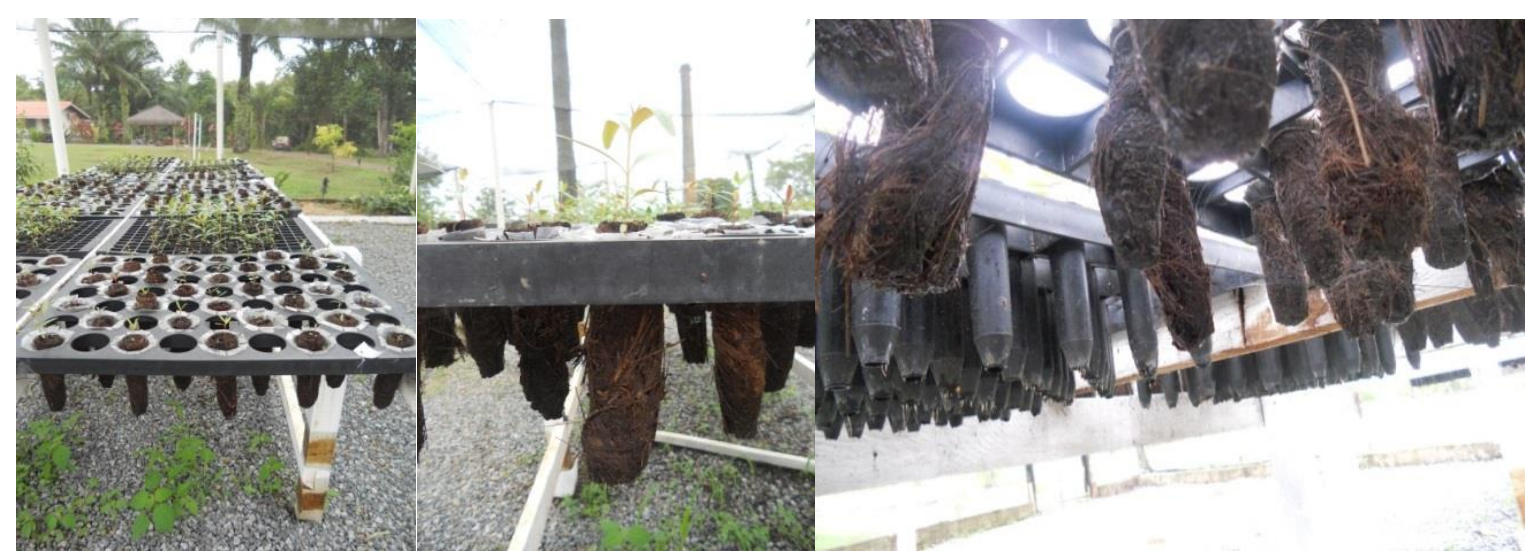

Figura 28: Tubetes para mudas, produzidos com os resíduos de produção da vassoura de piaçava, cidade de Nilo Peçanha na Casa Familiar Agroflorestal - CFAF.

Savastano Jr.; Pimentel (2000) testaram a utilização dos resíduos de piaçava para obtenção de materiais como telhas, painéis de vedação vertical, caixas d’água e pias de cozinha. Esses autores afirmam que na etapa de limpeza e penteamento (prébeneficiamento) das fibras vegetais perde-se cerca de $30 \%$ do material e, que estes são queimados ao ar livre. Além dos materiais que são descartados na etapa de confecção das vassouras.

Alguns autores estimam que cerca de $30 \%$ da fibra vegetal é descartada como resíduo nas ndustrias de transformação, após a produção (AGRELA, 2009; D’ALMEIDA et al., 2006; D’ALMEIDA et al., 2006b; AQUINO, 203).

Análises sobre os efeitos de alguns tratamentos nas propriedades mecânicas das fitas da piaçava, subproduto do pré-beneficiamento da fibra bruta, realizadas por Miranda et al. (2014), concluíram que a lavagem da fita de piaçava com água removeu parcialmente as impurezas da superfície das fibras, deixando-a mais rugosa, preservando os maiores

\footnotetext{
${ }^{25}$ A CFAF é uma unidade de ensino que oferece o Curso de Educação Profissional Técnico em Florestas, integrado ao ensino médio, para os jovens agroextrativistas da região de Nilo Peçanha e municípios vizinhos. Ação financiada e gerida pela Fundação Odebrecht.
} 
valores das propriedades mecânicas das fitas, quando comparado aos tratamentos da fita com aditivos.

Estudos para o aproveitamento dos resíduos decorrentes do aproveitamento da fibra vegetal na confecção de vassouras são de grande importância para indústrias de vassouras localizadas na Bahia, Rio de Janeiro, São Paulo, Minas Gerais, Espirito Santo. Ressalta-se que não foi encontrado produtos a base de resíduos da piaçava no mercado consumidor brasileiro. Todos ainda estão em fase experimental, necessitando de aprimoramento e análises de custos, além de empresários interessados em fabrica-los e comercializa-los.

Portanto o principal produto florestal da piaçava, oriundo das fibras vegetais, brasileiro, é a vassoura de piaçava para uso doméstico e limpeza urbana. A Figura 29 apresenta os diversos tipos de vassouras encontradas no mercado consumidor nacional.

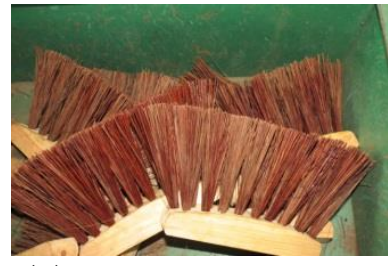

(a)

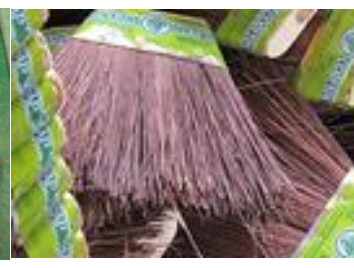

(b)

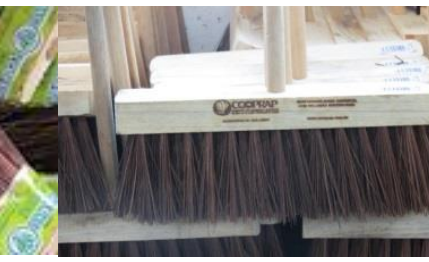

(c) (d)

Figura 29: Vassouras de piaçava: cepo de chita em madeira (a), cepo de metal (b), vassoura para limpeza urbana (c) e vassoura de pia e banheiro (d).

Silva; Guimarães (2006) apontaram que o comprimento das fibras nas plantas jovens foi $36 \%$ superior à de plantas adultas, porém não apresentou diferenças significativas no diâmetro. Os autores afirmaram também que a produção de fibras está diretamente relacionada com a produção das folhas, a maior e melhor quantidade de fibras nas plantas jovens foi atribuída ao fato de que nestas, toda a energia é alocada na produção vegetativa, enquanto na planta adulta uma grande parte da energia obtida é alocada para a produção de flores e frutos.

Para Silva (2002) as fibras colhidas e beneficiadas podem atingir mais de $2 \mathrm{~m}$ de comprimento, têm grande resistência à ruptura; a produtividade de uma palmeira está entre $2,5 \mathrm{~kg}$ a $7,5 \mathrm{~kg}$ de fibra por planta (valor médio de 5,3 kg); a elasticidade varia entre 1,75\% e $9 \%$ e o diâmetro, em torno de $1,1 \mathrm{~mm}$.

É possível notar a importância da fase fenológica da palmeira na qualidade e quantidade de fibra, bem como época de produção de frutos, técnicas de manejo florestal adotadas na extração vão influir nas etapas seguintes: pré-beneficiamento, beneficiamento e confecção de vassouras. 


\subsection{2 - Cadeia Produtiva da Fibra Vegetal da Piaçava}

Segundo Guimarães; Silva (2012) a cadeia produtiva da piaçava é essencialmente extrativista e, por isso, observam a carência de pesquisas, falta de assistência técnica e a desorganização do setor, fato que também é prejudicial na competição com as fibras sintéticas (por exemplo o nylon) e outras fibras naturais. Os autores acreditam que a perspectiva é a definição de um pacote técnico, com base em estudos, para que a piaçava deixe de ser puro extrativismo e torne-se uma cultura agrícola. Os autores acreditam que o mercado para as fibras vegetais, bem como para borra ('fita'), o carvão, os óleos etc., não podem ser feitos baseados em demandas extrativistas. Também afirma que de todas as espécies de palmeiras do mundo, a ciência só considera quatro em fase avançada de domesticação: o coco (Cocos nucifera L.), o dendê (Elaeis guineenses Jacq), a tâmara (Phoenix dacttylifera L.) e a pupunha (Bactris gasipaes Kunth). Especificamente sobre a piaçava (VINHA; SILVA, 1998; SILVA, 2002) esses autores apontam a necessidade de estudar e caracterizar diferentes fenótipos existentes entre os povoamentos para futura seleção de variedades e híbridos mais produtivos, conforme exigências do mercado: plantas produtoras de fibras (massa, comprimento, diâmetro e flexibilidade) e de frutos (quantidade/cacho, tamanho e espessura do endocarpo). Ressaltam a necessidade de desenvolver consistentes trabalhos de conservação de germoplasma dessa palmeira com potencial para a produção agrícola.

O sistema de comercialização da fibra da Piaçava na Bahia, apresentado por Moreu (1997), afirma que o caminho seguido pela fibra vegetal, desde a sua extração até o consumidor final, passa pelo piaçaveiro, segue para o empreiteiro, produtor, $1^{\circ}$ comprador, $2^{\circ}$ comprador, indústria e consumidores (fábricas locais, outros estados e exportações). Afirma que neste contexto a margem de ganho do extrativista na extração e comercialização da fibra bruta, varia entre $15 \%$ em 4 dos 6 caminhos apontados no fluxograma do sistema de comercialização (Anexo II), e 50\% em um único caminho onde o piaçaveiro é proprietário da área, colhe sua produção de forma familiar e vende para o $1^{\circ}$ comprador que ficaria com $10 \%$ e o $2^{\circ}$ comprador com $40 \%$ da renda bruta obtida na comercialização da fibra da piaçava.

Diante deste contexto, na etapa de manejo e pré-beneficiamento, etapas onde o extrativista da piaçava fica com a menor margem da renda na comercialização da fibra bruta, mesmo sendo os responsáveis pelas etapas mais insalubres de todo a cadeia produtiva, iniciou-se uma pequena ação do governo federal na região. A esses fatores 
soma-se o fato de que os preços praticados no mercado são inferiores ao custo de produção ou de extração da fibra vegetal bruta e que essas pessoas são em sua maioria quilombolas ou agricultores familiares, pessoas com pequenas propriedades nas áreas de ocorrência natural da espécie, ou donas de antigos roçados com mata de piaçava plantada, o governo federal através da PNSB $^{26}$ incluiu a cadeia de valor da piaçava em suas ações desde o ano de 2008.

A cadeia de valor da piaçava foi desenhada considerando os vários elos, atores locais, operadores e caminhos realizados pela fibra vegetal até o consumidor final (Anexo III). O principal resultado deste esforço foi a implantação da Politica de Garantia de preço Mínimo da Biodiversidade (PGPMBio) durante os anos de 2010, 2011 e 2012. Em 2010, os municípios de Cairu, Ituberá e Nilo Peçanha atingiram a quantidade de $262.281 \mathrm{~kg}$, atendendo 133 extrativistas, perfazendo um valor de R\$182.106,46. Em 2012 a quantidade negociada atingiu $4.600 .820 \mathrm{~kg}$, atendendo 1.136 extrativistas, perfazendo um valor de $\mathrm{R} \$$ 2.056.006,45. Em 2012 a média do preço pago ao produtor da fibra de piaçava bruta é de $\mathrm{R} \$ 1,23 \mathrm{~kg}$, representando um acréscimo nominal de 14,95\% em relação ao preço praticado no espaço de doze meses atrás. As ações da CONAB elevaram o preço da arroba de fibra bruta de $\mathrm{R} \$ 14,00$ para $\mathrm{R} \$ 25,00$ (CONAB, 2012).

A cadeia de valor da piaçava na Bahia, enquanto politica publica, atuou na região do Território do Baixo Sul, região também conhecida como Costa do Dendê ou costa Sul da Bahia, nos municípios: Valença, Cairu, Taperoá, Nilo Peçanha, Ituberá, Igrapiúna e Camamu (Figura 30). As ações tiveram como meta a formação do arranjo produtivo local APL da piaçava no Baixo Sul Baiano (OLIVEIRA, 2012).

${ }^{26}$ Plano Nacional da Sociobiodiversidade 


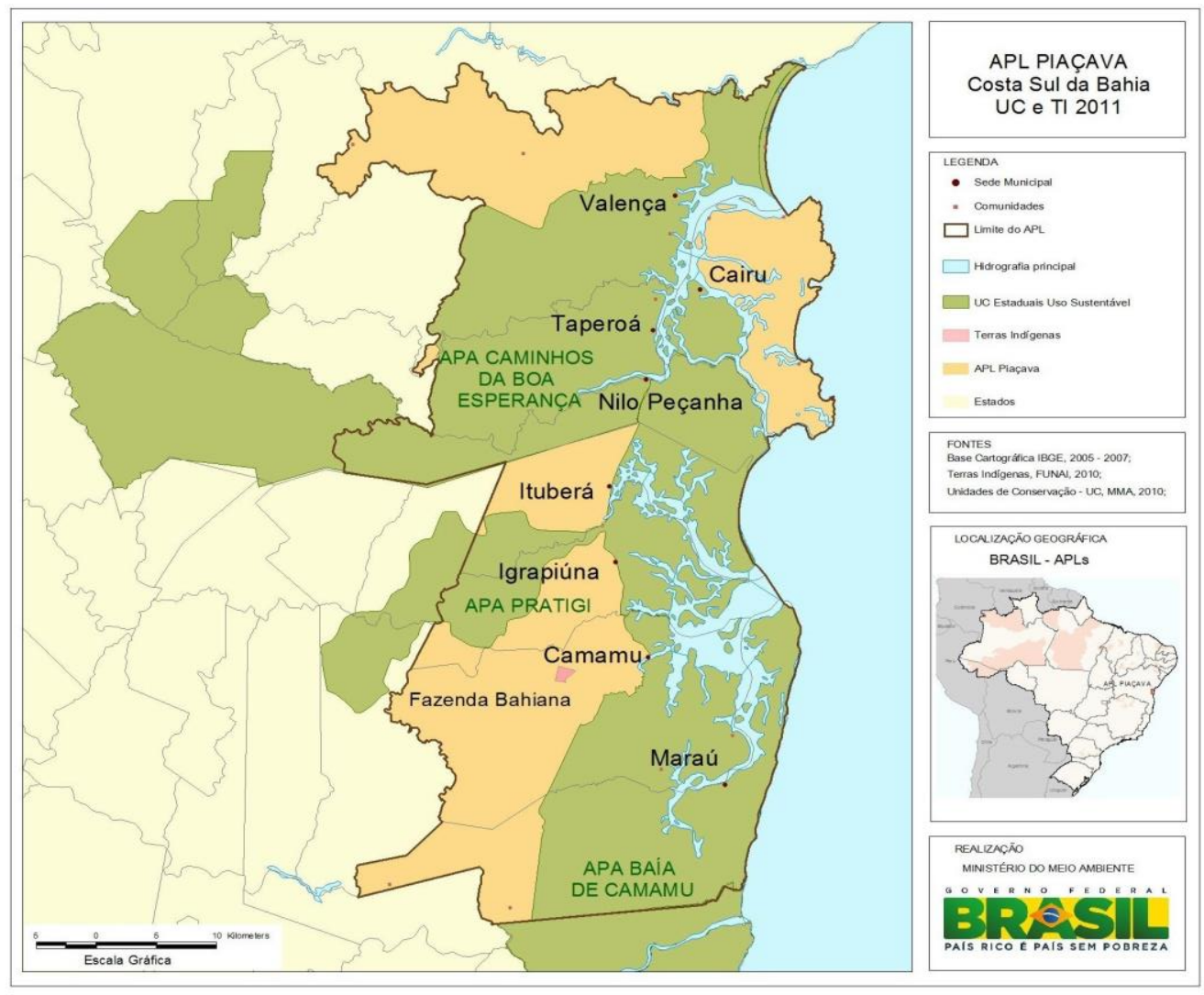

Figura 30: APL da Piaçava, unidades de conservação e terras indígenas (2011). Fonte: MMA apud Oliveira (2012).

A população total do território do APL - Arranjo Produtivo Local do Baixo Sul da Bahia em 2010 foi de 229.540 habitantes. Em 2009, o valor total do Produto Interno Bruto - PIB dos municípios foi de R\$ 1.594.869.000 e o valor total adquirido com o extrativismo da fibra da piaçava, $\mathrm{R} \$ 58.832 .000$. O extrativismo da fibra de piaçava representou, em média, 3,69\% do PIB do APL local, sendo ainda mais significativo para a economia do município de Nilo Peçanha que representou 29,60\% do PIB (OLIVEIRA, 2012).

A população total do território do APL - Arranjo Produtivo Local do Baixo Sul da Bahia em 2010 foi de 229.540 habitantes. Em 2009, o valor total do Produto Interno Bruto - PIB dos municípios foi de R\$ 1.594.869.000 e o valor total adquirido com o extrativismo da fibra da piaçava, $\mathrm{R} \$ 58.832 .000$. O extrativismo da fibra de piaçava representou, em média, 3,69\% do PIB do APL local, sendo ainda mais significativo para a economia do município de Nilo Peçanha que representou 29,60\% do PIB (OLIVEIRA, 2012).

Porém, juntando as subvenções pagas em 2010 e 2011 foi gastos apenas 49,7\% do valor previsto, fato que evidencia a falta de organização, capacitação e experiência de gestão das associações e cooperativas da região, com vista à construção de um canal de comercialização, ou simplesmente inserir seu produto no mercado (CONAB, 2013). 
O custo de produção da fibra bruta, calculado pela CONAB, considera principalmente gasto com a mão de obra ( $\mathrm{R} \$ 23,99$ por arroba); gastos com transporte interno ( $\mathrm{R} \$ 1,31$ por arroba); administrativo ( $\mathrm{R} \$ 0,78$ por arroba); e transporte externo (R\$ 0,86 por arroba) totalizando na safra de 2014. O preço mínimo é a somatória destes custos que na safra de 2014 foi de $\mathrm{R} \$ 26,94$ por arroba de fibra suja ou $\mathrm{R} \$ 1,80$ por quilo de fibra suja (CONAB, 2014). O valor da fibra bruta comercializada na região de Ituberá e Nilo Peçanha, em 2014, ficou entre 17,00 a 18,00 por arroba de fibra suja. A subvenção é a diferença entre o preço justo menos o valor comercializado, considerando esses valores apresentados, a subvenção é aproximadamente $\mathrm{R} \$ 9,94$ por arroba de fibra bruta comercializada com nota fiscal no ano de 2014.

O aproveitamento da folha da piaçava mirim que ocorre no litoral norte da Bahia, município de Entre Rios, principalmente na comunidade de Massanrudupió, são utilizadas para fazer o artesanato. Segundo (BARRETO, 2009) as extrativistas da Associação das Artesãs de Massarandupió - ADM obtinham uma renda em torno de R\$180,00 por mês. As mulheres fazem todo o trabalho de colheita da palha (folha da piaçava da Bahia), cozinham, secam, riscam, pintam, trançam e fazem as peças artesanais com a linha do licuri (Syagrus coronata) para vender na própria comunidade e feiras externas.

\section{4 - MATERIAL E MÉTODOS}

\subsection{1. Área de Estudo}

O processo produtivo de aproveitamento da fibra vegetal foi avaliado através da aplicação de questionário junto a duas cooperativas, COOPRAP e COOPAFABSUL (Apêndice C); visita in loco para acompanhamento da rotina produtiva nos 'catadouros' da região de Ituberá, Nilo Peçanha e Canavieiras; realização de experimentos, ou seja, ensaios de rendimentos em seis unidades produtivas: duas cooperativas; 'catadouro' familiar quilombola; 'catadouro' familiar dos 'meeiros' da propriedade particular; e 'catadouro' familiar em Ituberá e Nilo Peçanha. A Figura 31 ilustra a localização dos empreendimentos englobados neste estudo, nas etapas de processamento da fibra vegetal e fruto da piaçava da Bahia.

O município de Ituberá está localizado na coordenada geográfica S $13^{\circ} 44^{\prime} 15^{\prime \prime}$ e W $39^{\circ} 08^{\prime} 47^{\prime}$ '. O município de Nilo Peçanha está localizado na coordenada geográfica $13^{\circ}$ 
$36^{`} 36^{\prime \prime} \mathrm{S}$ e $39^{\circ} 06^{\prime} 13^{\prime \prime} \mathrm{W}$. O município de Canavieiras está localizado na coordenada geográfica S $15^{\circ} 46^{\prime} 37^{\prime \prime}$ e W $38^{\circ} 58^{\prime} 19^{\prime \prime}$.

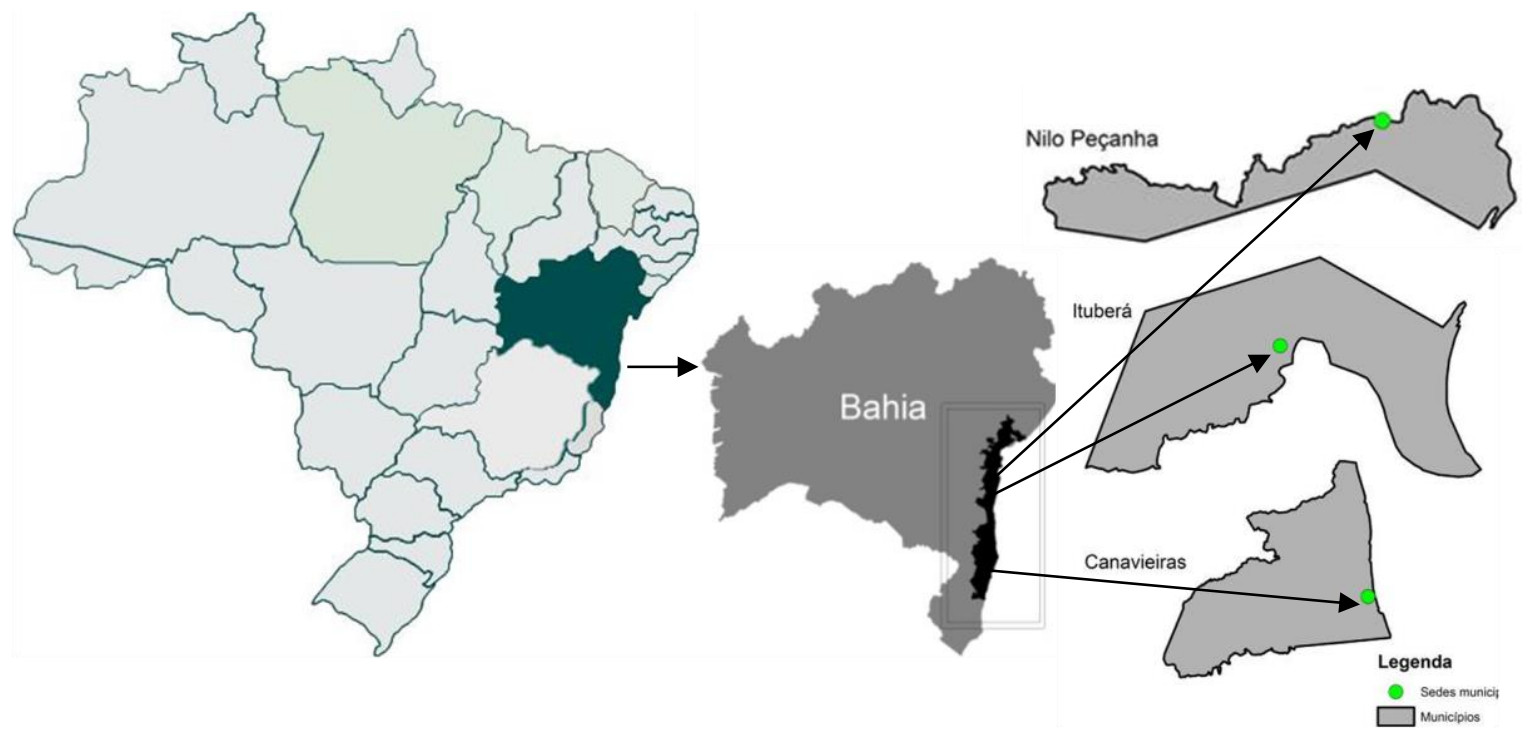

Figura 31: Localização dos empreendimentos avaliados na etapa de processamento da fibra vegetal e frutos da piaçava da Bahia.

\subsection{2 - Metodologia do Processo Produtivo da Fibra Vegetal da Piaçava}

A metodologia utilizada para avaliar o processo produtivo dos produtos oriundos da piaçava (Attalea funifera Mart.) consistiu: a) visita in loco às áreas de extração da fibra bruta; b) realização de ensaios de rendimento com a fibra bruta até a confecção de vassouras, em empreendimentos que realizam o pré-beneficiamento, beneficiamento e confecção da vassoura (Apêndice C).

Os ensaios de rendimento apontaram parâmetros quantitativos sobre o rendimento das etapas e técnicas utilizadas dentro do processo; rendimentos de fibra limpa; formação de matéria prima para subprodutos e quantificação de resíduos do processamento; rendimento do conjunto de atividades e equipamentos necessários para beneficiar a fibra de piaçava; a partir da etapa de extração da fibra bruta até a confecção de vassouras, além de informações qualitativas.

Os resultados apresentados consideram todos os ensaios realizados ao longo dos anos de 2012, 2013 e 2014, nos seis empreendimentos, adotou-se diferentes repetições nos ensaios realizados ao longo da pesquisa. $\mathrm{O}$ aumento do numero de repetições e diminuição 
da massa inicial dos ensaios de rendimento, objetivaram diminuir o coeficiente de variação apontado nas análises preliminares. Como já foi dito, a realidade produtiva dos empreendimentos diferem entre si, principalmente quanto às etapas do processamento da fibra (Figura 32).

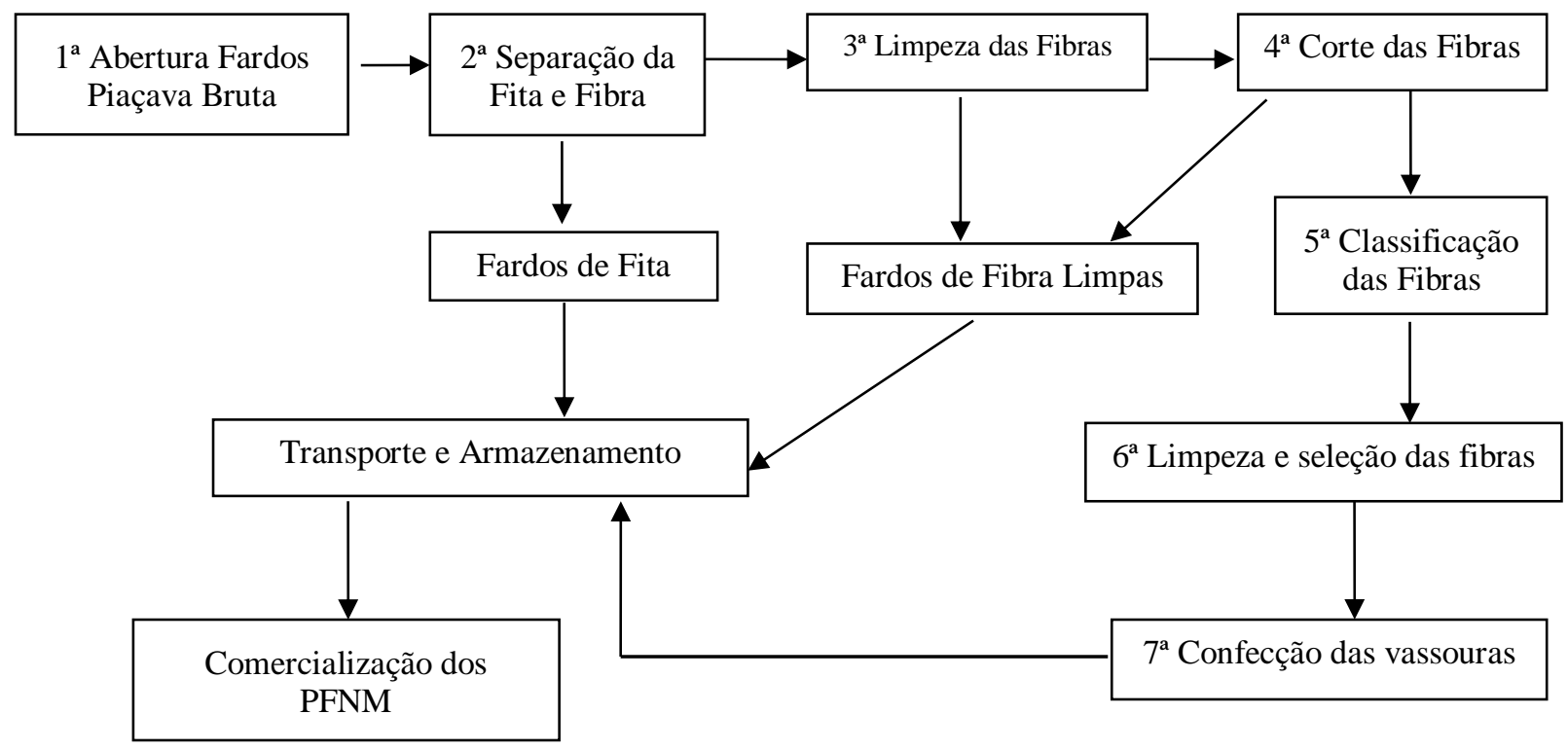

Figura 32: Etapas do processamento da fibra vegetal na confecção de vassouras de piaçava.

Esse fluxograma da Figura 32 reúne as diferentes etapas, realizadas nesses seis empreendimentos analisados, assim o processamento da vibra vegetal da piaçava está dividido em sete etapas. As etapas 1, 2 e 3 correspondem ao pré-beneficiamento; as etapas 3,4 e 5 ao beneficiamento e as etapas 6 e 7 ocorrem no momento da confecção das vassouras de piaçava.

\subsubsection{1 - Empreendimentos Avaliados}

O empreendimento I está inserido no quilombo Brejo Grande e tem a produção da piaçava da Bahia organizada pela Associação Quilombola do Brejo Grande de Ituberá AQBGI, localizada na zona rural de Ituberá, Bahia, distante $35 \mathrm{~km}$ da sede do município. Foram avaliadas as etapas de pré-beneficiamento (janeiro, 2014) e beneficiamento (abril, 2013) da fibra vegetal da piaçava. A declaração de anuência da comunidade quilombola consta no Anexo I.

O empreendimento II corresponde aos trabalhadores 'meeiros' que extraem em parceria com a propriedade particular do produtor Sr. Pedro Matos, fazenda Nova Vida, 
localizada a $30 \mathrm{~km}$ da sede do munícipio de Canavieiras, Bahia. Neste caso somente a etapa de pré-beneficiamento foi avaliada junto aos 'meeiros' (abril, 2013).

O empreendimento III consiste no 'catadouro' familiar do Sr. Alan, localizado na zona rural a $25 \mathrm{~km}$ da sede do município de Nilo Peçanha, Bahia. Essa unidade produtiva processa a fibra vegetal bruta e comercializa a fibra cortada, o experimento avaliou as duas etapas: pré-beneficiamento e beneficiamento (outubro, 2012).

O empreendimento IV trata do 'catadouro' familiar do Sr. Hamilton Assunção, está localizado na cidade de Ituberá, Bahia. Essa unidade produtiva processa a fibra vegetal bruta e comercializa cortada, para a COOPRAP, pois este produtor é um cooperado. Experimento realizado em março de 2014.

$\mathrm{O}$ empreendimento $\mathrm{V}$ corresponde à COOPRAP, localizada na cidade de Nilo Peçanha, Bahia. Realizaram-se dois experimentos, outubro de 2012 e março de 2014, iniciando com as fibras limpas e cortadas (beneficiadas) e finalizando com a vassoura de cepo (18 frutos) pronta para o cabeamento e comercialização. Para diferir cada experimento adotou-se $\mathrm{V}$ (a) para o experimento de março de 2014 e $\mathrm{V}(\mathrm{b})$ para o experimento de 2012.

O empreendimento VI é a COOPAFBASUL, localizada na cidade de Ituberá, Bahia, com dois galpões de produção descentralizados na zona rural do município, comunidade Chico de Dora e quilombo Brejo Grande. Foi realizado experimento no quilombo Brejo Grande, em abril 2013, análise das etapas de confecção das vassouras de piaçava. A Tabela 35 sintetiza o delineamento experimental adotado em cada empreendimento e o período em que foi realizado o levantamento dos dados.

Tabela 35: Delineamento experimental pré-beneficiamento e beneficiamento

\begin{tabular}{|c|c|c|c|c|c|c|}
\hline Empreendimento & $\mathbf{N}^{\circ}$ & Rep. & $\begin{array}{c}\text { Fibra }(\mathrm{kg}) / \\
\text { sistema }\end{array}$ & $\begin{array}{c}\text { Total (kg)/ } \\
\text { sistema }\end{array}$ & $\begin{array}{l}\text { Massa } \\
\text { Inicial }\end{array}$ & $\begin{array}{l}\text { Mês } \\
\text { Ano }\end{array}$ \\
\hline $\begin{array}{l}\text { Quilombo Brejo } \\
\text { Grande }\end{array}$ & I & 14 & 4 & 56 & Bruta & Jan/14 \\
\hline $\begin{array}{c}\text { Quilombo Brejo } \\
\text { Grande }\end{array}$ & I & 8 & 2 & 16 & Limpa & Abril/13 \\
\hline $\begin{array}{c}\text { 'Meeiros' } \\
\text { Canavieiras }\end{array}$ & II & 8 & 4 & 32 & Bruta & Abril/13 \\
\hline "Catadouro" Alan & III & 5 & 7 & 35 & Bruta & Out/12 \\
\hline $\begin{array}{l}\text { 'Catadouro' } \\
\text { Hamilton }\end{array}$ & IV & 14 & 3 & 42 & Limpa & Março/14 \\
\hline COOPRAP & $\mathrm{Va}$ & 14 & 2 & 28 & Cortada & Março/14 \\
\hline COOPRAP & $\mathrm{Vb}$ & 5 & 2,6 & 13 & Cortada & Out/12 \\
\hline COOPAFBASUL & VI & 8 & 2 & 16 & Cortada & Abril/13 \\
\hline
\end{tabular}


Os ensaios do pré-beneficiamento da fibra iniciaram com $4 \mathrm{~kg}$ de fibra bruta e 14 repetições no empreendimento $\mathrm{I}$; com $4 \mathrm{~kg}$ de fibras brutas e 8 repetições no empreendimento II; e com $7 \mathrm{~kg}$ e 5 repetições do empreendimento III.

As variáveis mensuradas na etapa de pré-beneficiamento foram: o tempo de separação da fibra e 'fita'; massa da fibra vegetal comercializável, fita e resíduos formados.

Os ensaios de beneficiamento da fibra vegetal, ou seja, corte, limpeza e seleção das fibras vegetais comercializáveis, iniciaram com $2 \mathrm{~kg}$ de fibras limpas e 8 repetições no empreendimento I; uma média de 4,7 kg e 5 repetições no sistema III; e $3 \mathrm{~kg}$ de fibra limpa e 14 repetições no empreendimento IV.

As variáveis mensuradas na etapa de beneficiamento foram: tempo de corte e seleção das fibras limpas; massa da fibra cortada comercializável; e massa dos resíduos formados.

Os ensaios de confecção de vassouras consistiram na seleção das fibras fino-médias e médio-grossas, limpezas e pregueamento das fibras cortadas no cepo das vassouras de piaçava, iniciaram com $2 \mathrm{~kg}$ de fibras cortadas e 14 repetições no empreendimento $\mathrm{V}(\mathrm{a}) ; 3$ $\mathrm{kg}$ e 5 repetições no empreendimento $\mathrm{V}(\mathrm{b})$; e uma média de $1,2 \mathrm{~kg}$ de fibras cortadas e 8 repetições no empreendimento VI.

As variáveis mensuradas na etapa de confecção das vassouras de piaçava foram: tempo de fixar as fibras no cepo das vassouras; massa de fibras fina-médias; massa de fibras grossas, $\mathrm{V}(\mathrm{a})$ e $\mathrm{V}(\mathrm{b})$, e resíduo formado nesta etapa produtiva.

Os equipamentos utilizados para os ensaios de rendimento foram os mesmos que os agroextrativistas e cooperativas utilizam para o pré-beneficiamento, beneficiamento e confecção de vassouras de piaçava. Todos os experimentos realizados com a fibra vegetal foram feitos em campo, dentro das unidades produtivas, sempre com a presença da pesquisadora e as determinações da massa inicial e as geradas foram realizadas com a balança eletrônica da marca Toledo modelo digital Prix 3/Prix 3 (bateria), com capacidade até $30 \mathrm{~kg}$, três casas decimais, adquirida para este fim. A Tabela 36 descreve todos os equipamentos utilizados na etapa de processamento da fibra vegetal. 
Tabela 36: Equipamentos necessários para produção de vassouras de piaçava e experimentos realizados em campo.

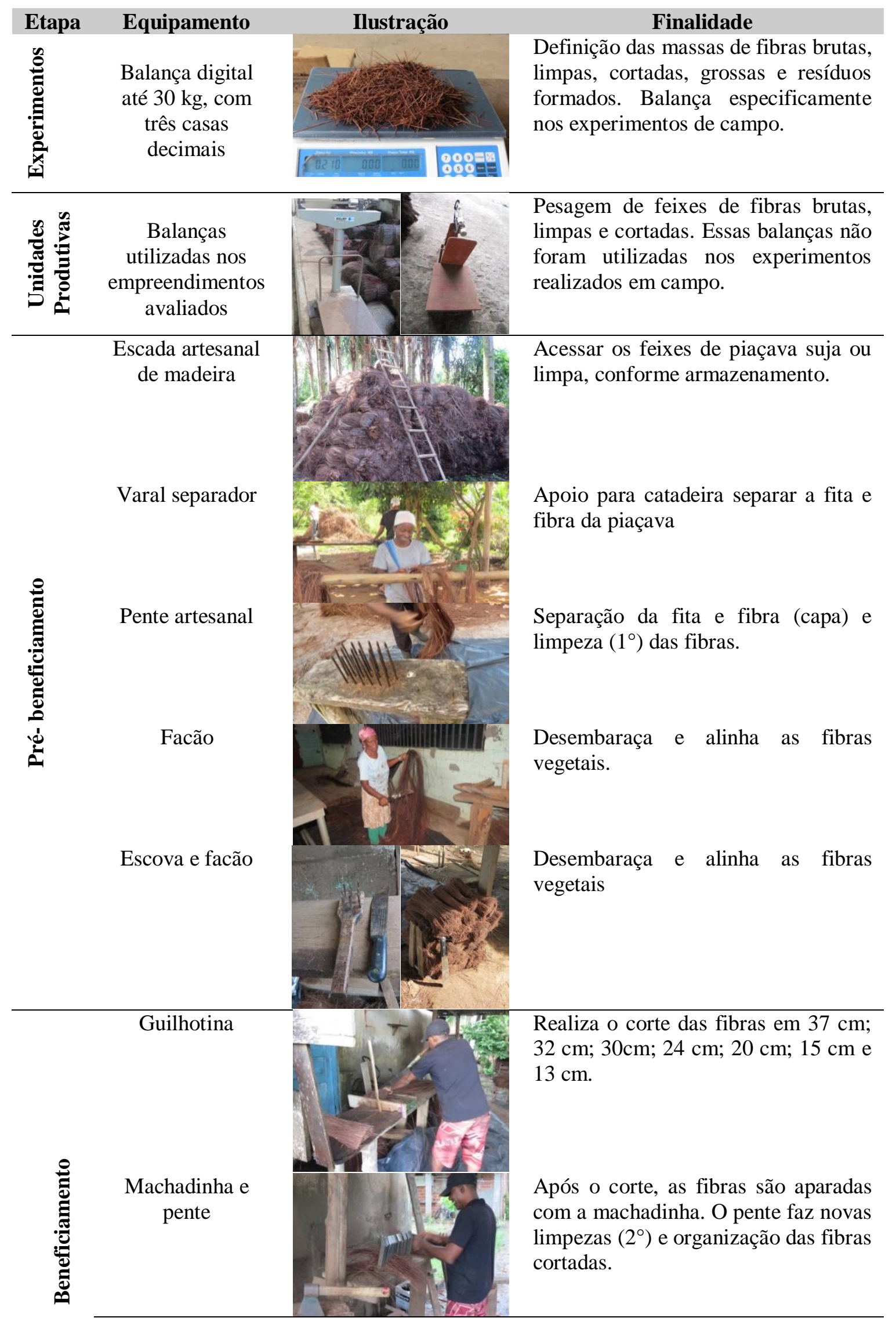




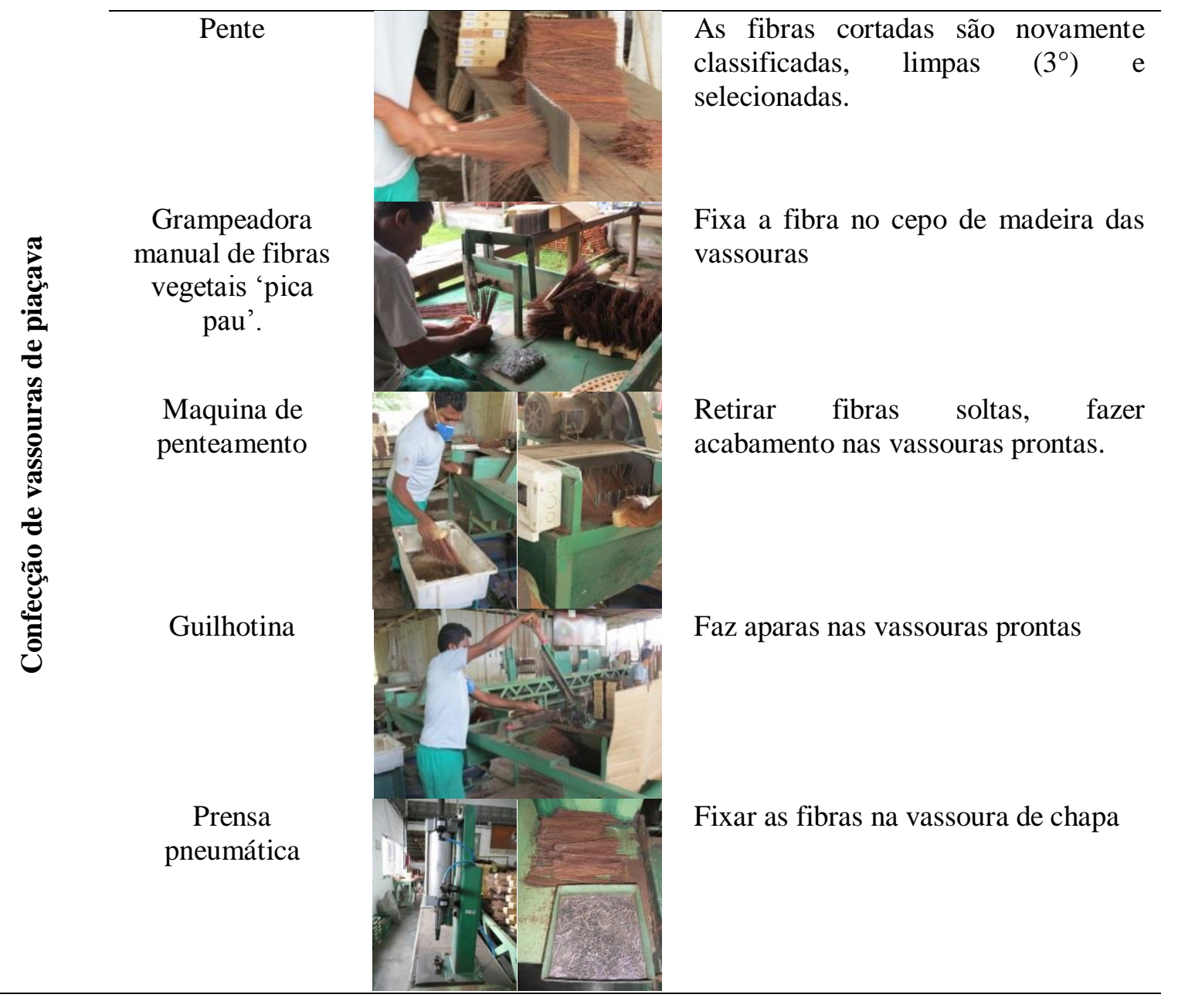

\subsubsection{1 - Tratamentos dos Dados}

As variáveis mensuradas para calcular os rendimentos em fibra vegetal dos seis empreendimentos foram: massa de fibra bruta (MFB); massa de 'fita' (MF); massa de fibra limpa (MFL); massa de fibra cortada (MFC); massa de fibra fina-media (MFF); massa de fibra grossa (MFG); massa de resíduos mensurados (MRM); massa de resíduos reais (MRR) e o tempo de seleção e cata (TSC), tempo de confecção das vassouras (TCV).

Para o calculo da percentagem do rendimento em fibra vegetal na etapa de prébeneficiamento utilizou-se a seguinte relação: massa de fibra limpa (MFL) dividido pela massa e fibra bruta (MFB), multiplicado por cem para obter a porcentagem. O rendimento de pré-beneficiamento final foi calculado considerando a média dos empreendimentos I, II e III. Assim o rendimento de 'cata' (RendCata) do pré-beneficiamento, foi dado pela equação:

$$
\operatorname{RdCata}(\%)=\frac{M F L}{M F B} * 100
$$


O rendimento em 'fita' também na etapa de pré-beneficiamento utilizou-se a seguinte relação: massa de 'fita' (MF) dividido pela massa e fibra bruta (MFB), multiplicado por cem para obter a porcentagem. O rendimento de 'fita' foi calculado considerando a média dos empreendimentos I, II e III. Assim o rendimento de 'fita' (RendFita) do pré-beneficiamento, foi dado pela equação:

$$
\text { RdFita }(\%)=\frac{M F}{M F B} * 100
$$

O calculo da percentagem do rendimento em fibra vegetal no beneficiamento utilizou-se a seguinte relação: massa de fibra cortada (MFC) dividido pela massa e fibra limpa (MFL), multiplicado por cem para obter a porcentagem. O rendimento do beneficiamento final foi calculado considerando a média dos empreendimentos I, III e IV. Assim o rendimento de corte (RdCorte) do beneficiamento foi dado pela seguinte equação:

$$
\text { RdCorte }(\%)=\frac{M F C}{M F L} * 100
$$

O calculo da percentagem do rendimento em fibra vegetal na confecção das vassouras de piaçava utilizou-se a seguinte relação: massa de fibra fina (MFF) dividido pela massa e fibra limpa (MFC), multiplicado por cem para obter a porcentagem. O rendimento da confecção de vassouras final foi calculado considerando a média dos empreendimentos $\mathrm{V}(\mathrm{a}), \mathrm{V}(\mathrm{b})$ e VI. Assim o rendimento de corte (RdFina) do beneficiamento foi dado pela seguinte equação:

$$
\text { RdFina }(\%)=\frac{M F F}{M F C} * 100
$$

A média de rendimento em fibras grossas foi calculada com os valores levantados na etapa de confecção de vassouras de piaçava, utilizando a relação da massa de fibra grossa (MFG), dividida pela massa de fibra cortada (MFC), multiplicado por cem para obter a porcentagem. Assim o rendimento em fibras grossas (RdGrossa) foi dado pela seguinte equação:

$$
\operatorname{RdGrossa}(\%)=\frac{M F G}{M F C} * 100
$$


O rendimento de resíduo formado em cada etapa foi calculado pela massa de resíduo mensurado (MRM) dividido pela massa de fibra inicial, seja massa de fibra bruta (MFB), ou massa de fibra limpa (MFL), ou massa de fibra cortada (MFC). Conforme a etapa analisada.

O rendimento de resíduo real (RdResíduo) foi calculado pela diferença entre cem por cento, menos as equações (somatória dos rendimentos da etapa em questão). Assim o RdResíduo foi dado pela seguinte equação:

$$
\text { RdResíduo }(\%)=100-(\text { RdCata }+ \text { RdFita })^{27}
$$

O rendimento residual formado menos o rendimento do resíduo real (RdResíduo), em cada etapa, corresponde ao erro do experimento realizado, ou seja, os materiais vegetais que se perderam ao longo do processo produtivo, aquilo que não é possível mensurar em um experimento de campo.

O rendimento do processo produtivo foi calculado com base nos coeficientes encontrados em cada uma das etapas produtivas: RdCata (\%); RdCorte (\%); RdFina (\%). Assim o rendimento do processo produtivo (RdProc) foi dado pela seguinte equação:

$$
\operatorname{RdProc}(\%)=((\text { RdCata }) *(\underline{\text { RdCorte }}) *(\underline{\text { RdFina }})) * 100
$$

Com essas informações foi possível calcular o índice de rendimento dos resíduos reais (RdResT), o resíduo formado no processo produtivo foi calculado somando-se o RdProc com RdFita menos cem, pela seguinte equação:

$$
\operatorname{RdResT}(\%)=100-(\text { RdProc }+ \text { RdFita }+ \text { RdGrossa })
$$

Esses índices foram utilizados para apontar cenários de ganhos dos agroextrativistas com a unificação das etapas produtivas em um único empreendimento familiar, conforme metodologia adota por Pimentel (2008).

\subsection{3 - Metodologia da Cadeia Produtiva}

A cadeia produtiva da piaçava apresentada neste estudo teve como base informações dos agroextrativistas, produtores e especialistas na piaçava, nos empreendimentos visitados: produtor particular de Canavieiras; 'meeiros' dessa

\footnotetext{
${ }^{27}$ Nas três etapas foram calculados os rendimentos em resíduos reais formados, ou seja, cem por cento menos o rendimento aproveitável comercialmente na etapa.
} 
propriedade; 'catadouro' familiar do Quilombo Brejo Grande; 'catadouro' familiar de Ituberá; 'catadouro' familiar na zona rural de Nilo Peçanha, COOPRAP e COOPAFBASUL, localizados nos municípios de Canavieiras, Ituberá e Nilo Peçanha, estado da Bahia, Brasil. Foram realizadas visitas às áreas de extração, entrevistas com os extrativistas da piaçava, cooperados e demais envolvidos com a cadeia produtiva da fibra vegetal da piaçava. O roteiro semiestruturado (Apêndice A) foi aplicado junto a esses atores da cadeia produtiva da piaçava.

Foram mapeados os atores e valores pagos aos profissionais envolvidos na cadeia produtiva, bem como os valores de venda da fibra bruta, fibra pré-beneficiada e beneficiada. Os cálculos das margens brutas de ganhos extrativistas foram feitos considerando o valor final de venda de uma arroba $(15 \mathrm{~kg})$ de fibra vegetal bruta e uma arroba (15 kg) de fibra vegetal cortada (beneficiada).

Considerando o potencial de uso multiplo da piaçava da Bahia, a seguir, apresentase as metodologias elaboradas para averiguar os rendimentos do epicarpo, mesocarpo (polpa), endocarpo, sementes e óleo veegtal dos frutos da piaçava da Bahia. Realizou-se dois experimentos distintos, pois, os frutos adequados para o aproveitamento da polpa do ‘satim' são diferentes dos frutos adequados para o aproveitamento das sementes para extração do óleo vegetal, entre outras questões específicas da espécie florestal e de logística de campo.

\subsection{4 - Metodologia de Aproveitamento do Fruto e da Polpa de 'Satim'}

O mingau de 'satim' é um alimento tradicionalmente consumido pelas comunidades quilombolas de Ituberá e Nilo Peçanha. Esse alimento tradicional é feito com a polpa ou mesocarpo do fruto da piaçava, também denominado de farinha do 'satim'.

A metodologia adotada para o aproveitamento do 'satim' e definição da porcentagem de epicarpo, mesocarpo, endocarpo e sementes, considerou os critérios tradicionais adotados na seleção dos frutos adequados para extração do 'satim'. Os critérios tradicionais foram informados pela família quilombola residente na zona rural de Ituberá, os especialistas foram: a Sra. Joanita Ribeiro Assunção, o Sr. André Souza Assunção e sua filha Sra. Josy Assunção.

Segundo a família extrativista, quilombola, o fruto ideal para fazer o 'satim' deve ser aquele que esta no inicio da maturação, ou seja, o cacho com os frutos ainda está na palmeira, mas alguns frutos já iniciaram o desprendimento do cacho e se encontram no 
chão. Esses frutos que estão no chão possuem as caracteristicas apropriadas para o aproveitamento do 'satim'. Esses frutos não devem ter sinais de ataque de roedores ou outros microrganismos, fato que inviabiliza o aproveitamento da polpa. A Figura 33 ilustra os frutos com as características adequadas para o aproveitamento do 'satim', detalhe da polpa e endosperma ósseo e um fruto que foi consumido pela fauna silvestre.

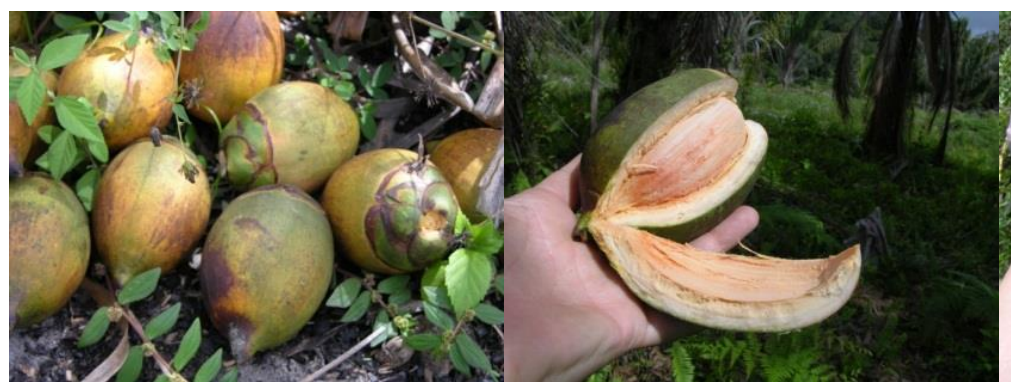

(a) (b)

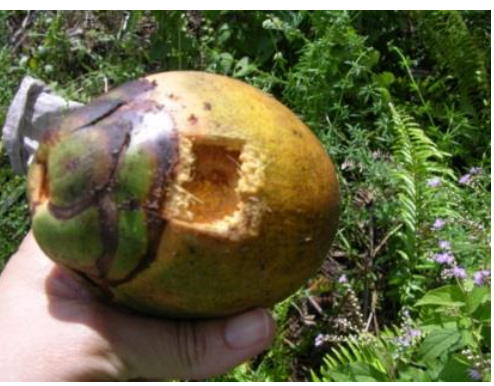

(c)

Figura 33: (a) Frutos da piaçava adequados para o aproveitamento da polpa do 'satim'; (b) fruto aberto e (c) detalhe de um fruto já consumido pela fauna silvestre.

A coleta dos frutos adequados para o aproveitamento da polpa de 'satim' foi realizada na propriedade do Sr. Carlos Alex Lima Guimarães, Fazenda São Miguel, localizada no município de Itacaré, Bahia. O experimento para definir as porcentagens de epicarpo, mesocarpo, endocarpo e sementes foi realizado na AQBGI, no município de Ituberá, Bahia, no mês de setembro de 2014.

Entre os frutos coletados (dia de chuva), foram selecionados, aleatoriamente, 30 frutos. Esses foram lavados em água corrente para retirar impurezas das áreas de extração, ou matas de piaçava, enxutos, numerados e pesados (Figura 34). Entre esses, após a retirada do epicarpo (casca) verificou-se que três frutos não apresentavam polpa de 'satim' ou mesocarpo, essas amostras foram descartadas. Entre os 27 frutos restantes, 13 frutos apresentaram sementes e 14 frutos não possuíam sementes. Portanto as médias de rendimento de epicarpo, mesocarpo e endocarpo foram calculadas com 13 repetições.

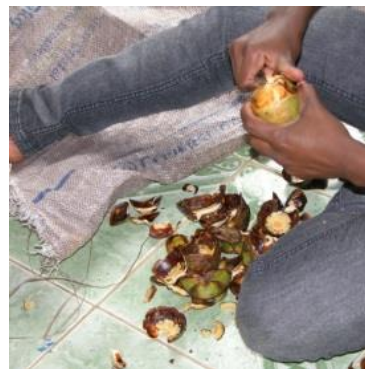

(a)

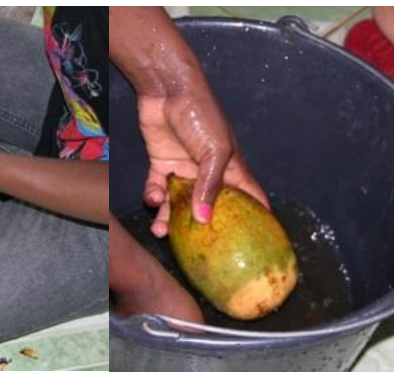

(b)

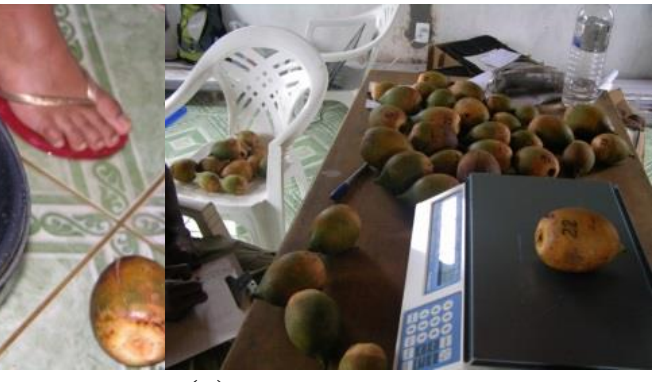

(c)

Figura 34: (a) Retirada do pedúnculo, (b) lavagem e (c) pesagem dos 30 frutos selecionados aleatoriamente. 
As massas foram definidas na balança eletrônica digital da marca Toledo modelo Prix 3/Prix 3 (bateria), com capacidade até $30 \mathrm{~kg}$, três casas decimais, para auferir as massas de epicarpo, mesocarpo e endocarpo. Para auferir as massas das sementes foi necessário a balança de precisão (Figura 35), cedida pela UFS (Universidade Federal de Sergipe).

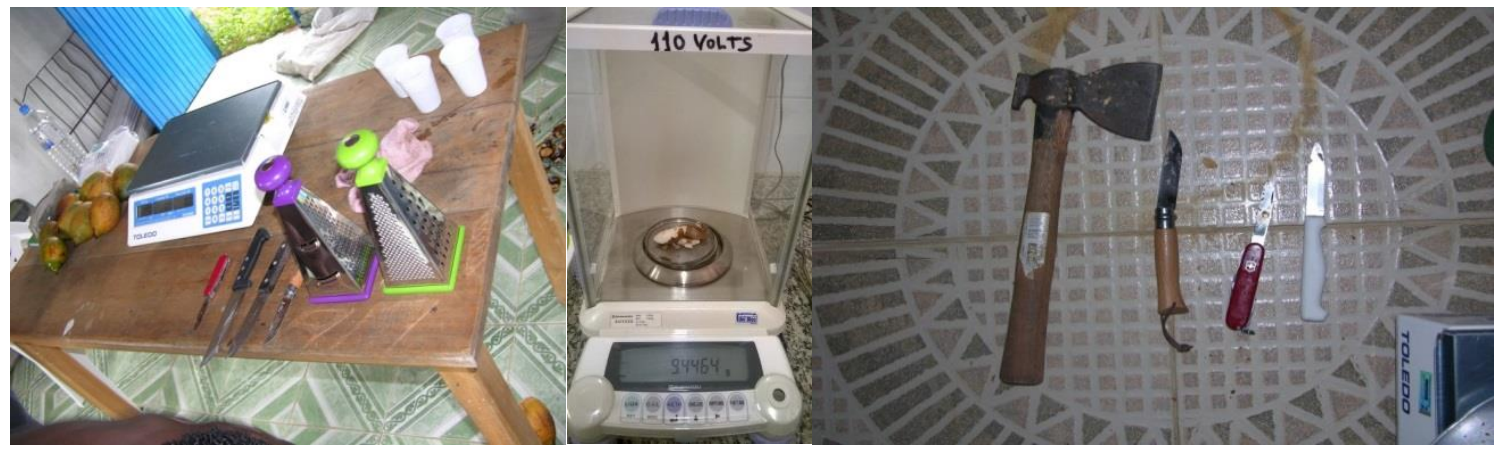

Figura 35: Materiais utilizados nos experimentos: balanças, raladores, facas e machadinha.

O beneficiamento dos frutos consistiu na retirada do epicarpo (casca) de cada fruto, com o uso de uma faca, a casca foi pesada e definida a massa. Em seguida retirou-se a parte mais fibrosa da polpa (mesocarpo fibroso) do fruto e pesado. A polpa restante é a matéria prima para se fazer o 'satim', neste experimento o 'satim' foi extraída por meio de ralador comum (Figura 36), conforme as técnicas tradicionais e recomendações dos quilombolas. Definiu-se a massa do 'satim', o tempo de extração e as amostras geradas foram acondicionadas em sacos plásticos e colocadas no freezer.

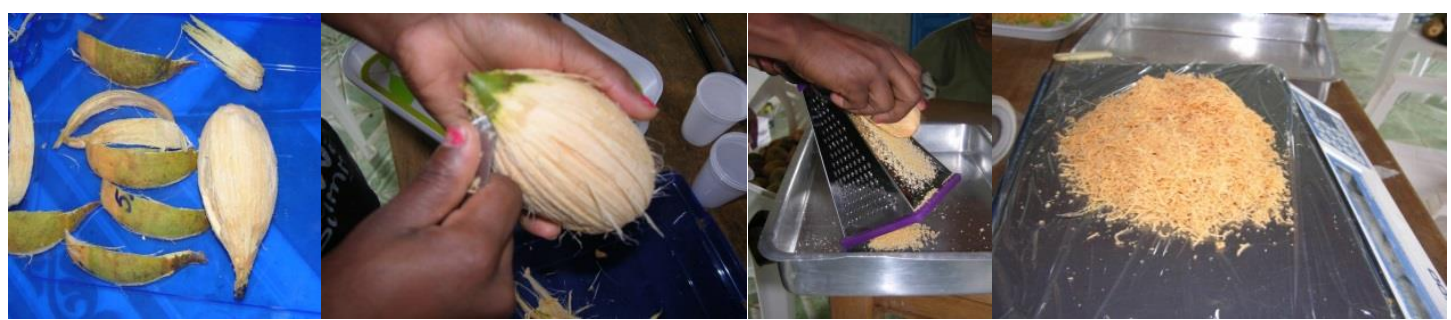

(a)

(b)

(c)

(d)

Figura 36: (a) Retirada da casca e (b) fibras grossas da polpa; e (c) extração do 'satim' com ralador e (d) a polpa de 'satim'.

O endocarpo e sementes foram pesados e acondicionados durante 48 horas até a extração das sementes. A extração das sementes de dentro do mesocarpo (ósseo) foi realizada manualmente, com uso do facão e faca, as sementes foram separadas 
cuidadosamente do endocarpo (Figura 37). Normalmente essas sementes estão aderidas ao mesocarpo. A escolha dos frutos para este experimento primou pela presença de polpa ou 'satim', esses frutos, geralmente, possuem pouca massa de semente, então essas tiveram que ser mensuradas em balança de precisão.

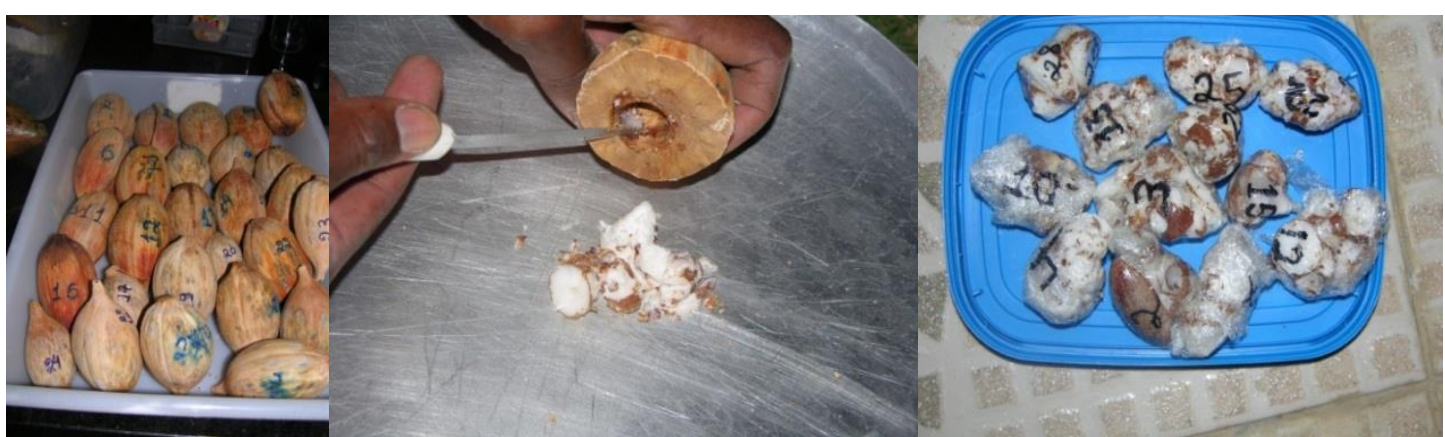

(a)

(b)

(c)

Figura 37: (a) Endocarpos dos frutos numerados; (b) extração das sementes de piaçava do interior do endocarpo e (c) sementes embaladas e numeradas.

Para o calculo da percentagem do rendimento em epicarpo utilizou-se a seguinte relação: massa do epicarpo (MEpicarp) dividido pela massa do fruto (MFruto), multiplicado por cem para obter a porcentagem.

$$
\text { RdEpicarp }(\%)=\frac{\text { MEpicarp }}{\text { MFruto }} * 100
$$

Para o cálculo da percentagem do rendimento em mesocarpo fibroso utilizou-se a seguinte relação: massa do mesocarpo (Mmesocarp Fibroso) dividido pela massa do fruto (MFruto), multiplicado por cem para obter a porcentagem.

$$
\text { RdMesocarp Fibroso }(\%)=\frac{\text { Mmesocarp Fibroso }}{\text { Mfruto }} * 100
$$

Para o cálculo da percentagem do rendimento em mesocarpo 'satim' utilizou-se a seguinte relação: massa do mesocarpo (Mmesocarp Satim) dividido pela massa do fruto (MFruto), multiplicado por cem para obter a porcentagem.

$$
\text { RdMesocarp Satim }(\%)=\frac{\text { Mmesocarp Satim }}{\text { Mfruto }} * 100
$$


Para o calculo da percentagem do rendimento em endocarpo utilizou-se a seguinte relação: massa do endocarpo (MEndocarpo) dividido pela massa do fruto (MFruto), multiplicado por cem para obter a porcentagem. Neste caso utilizou-se o valor calculado da massa do endocarpo, ou seja, diminui-se o valor da massa do mesocarpo pela massa das sementes.

$$
\text { RdEndocarp }(\%)=\frac{\text { MEndocarp }}{\text { Mfruto }} * 100
$$

Para o cálculo da percentagem do rendimento em sementes utilizou-se a seguinte relação: massa do endocarpo (Msementes) dividido pela massa do fruto (Mfruto), multiplicado por cem para obter a porcentagem.

$$
\text { RdSementes }(\%)=\frac{\text { Msementes }}{\text { Mfruto }} * 100
$$

\subsection{5 - Metodologia de Aproveitamento do Óleo Vegetal}

A coleta de frutos da piaçava foi realizada em março de 2014, na Fazenda Santa Rita, zona rural do município de Ituberá, Bahia, plantio do quilombola Sr. André Souza Assunção (Figura 38). Esse plantio foi implantado há aproximadamente 50 anos atrás e a coleta foi feita durante o período de safra (março a junho).

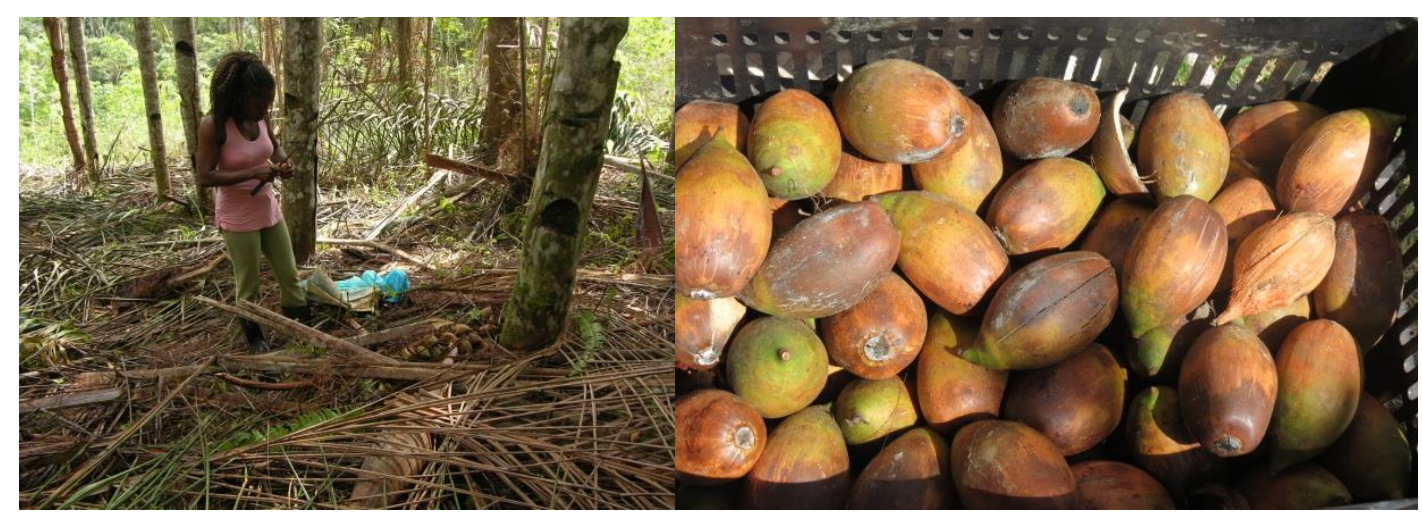

Figura 38: Coleta dos frutos 'de vez' e maduros da piaçava.

Os frutos foram colhidos no chão, após a queda espontânea, que possivelmente ocorreu há um mês. Os frutos são encontrados de duas formas: (a) frutos com casca externa e (c) frutos sem a casca externa (Figura 39) devido à ação de roedores e processos de decomposição dos mesmos. Deve-se ressaltar que a amostra coletada, neste experimento, estava com a polpa do 'satim' seca, sendo retirada junto com epicarpo durante a extração 
Figura 45. Portanto o epicarpo (casca) e mesocarpo (polpa) foram pesados juntos devido ao estágio de maturação dos frutos. Os ensaios foram realizados em campo, balança digital com precisão de até três casas decimais (marca Toledo modelo Prix 3/Prix 3).

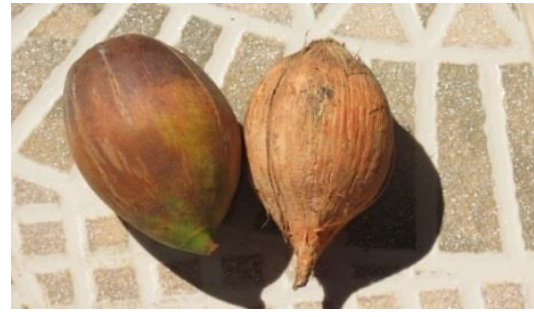

(a)

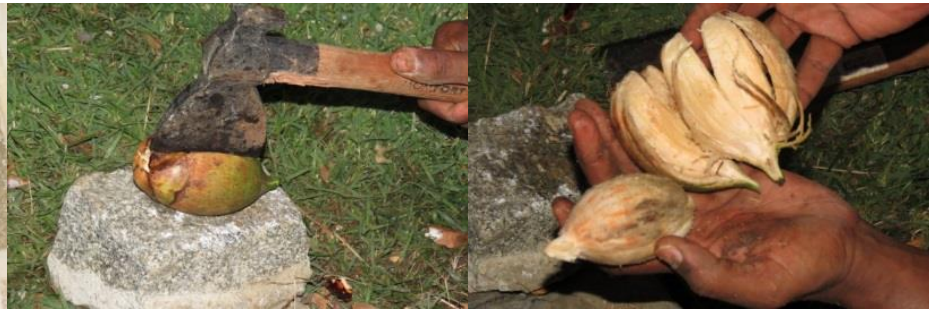

(b) (c)

Figura 39: (a) Fruto com casca externa e sem casca externa; (b) Retirada da casca e polpa do fruto com machadinha e; (c) casca e polpa separada do endocarpo.

Foram selecionados 14 frutos com casca, a amostra diminui para 10 frutos devido ao cancelamento de quatro amostras sem sementes. Os frutos foram pesados e a retirada da casca (epicarpo) e a polpa (mesocarpo) foi feita de uma só vez, devido ao estágio de maturação dos mesmos. Os endocarpos foram apoiados em uma pedra para a aplicação da força de quebra do endocarpo ósseo e posterior extração das sementes.

A extração das sementes foi feita manualmente com faca (Figura 40), posteriormente pesadas e armazenadas em câmara fria $\left(10^{\circ} \mathrm{C}\right)$ para conservação do endosperma, ou seja, massa interior de coloração branca e homogênea, até o seu processamento ainda no mês de março de 2014.

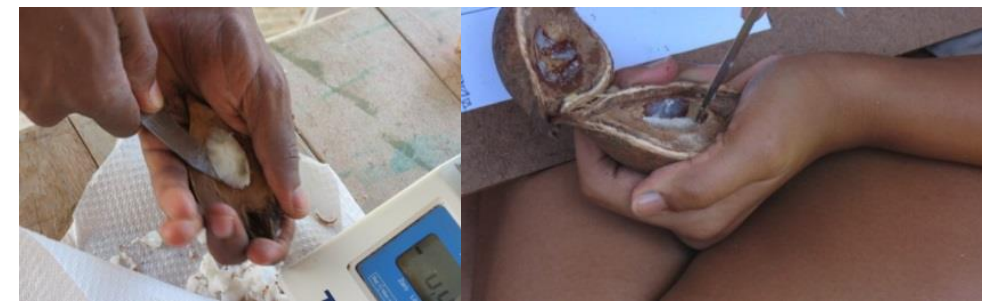

(a) (b)

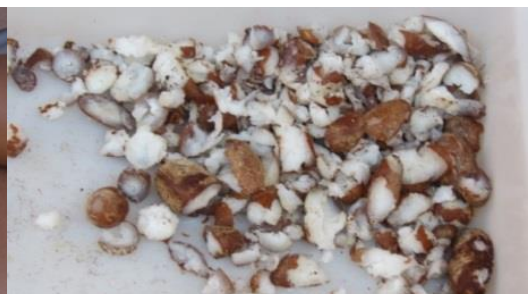

(c)

Figura 40: (a) e (b) Extração manual das sementes da piaçava de dentro do endocarpo ósseo com faca e (c) sementes já retiradas.

A extração do óleo vegetal foi realizado no Laboratório de Oleaginosas da Embrapa Cerrados (Planaltina-DF), no mês de março de 2014 e, as amostras de óleo foram entregues ao Prof. Floriano Pastore, do Instituto de Química da UnB, para as devidas análises e continuidade das análises aqui iniciadas. 


\subsubsection{1 - Secagem e Determinação do Teor de Umidade Percentual}

Para determinação do teor de umidade percentual das sementes foram separadas amostras de 50g cada, em cinco repetições das sementes maduras e cinco repetições das sementes 'de vez'. Foram submetidas à secagem em estufas $\left(65^{\circ} \mathrm{C}\right)$ durante $24 \mathrm{~h}$, conforme procedimento usual adotado pelo Laboratório de Oleaginosas da Embrapa Cerrados (Planaltina-DF), com objetivo de se atingir a massa constante após este período. O teor de umidade percentual das sementes (TU) foi determinado utilizando-se a Equação 2.14 proposta por Brasil (2009), com base na massa úmida das sementes (MUS).

$$
T U(\%)=\frac{M U S-M S S}{M U S} * 100
$$

\subsubsection{2 - Extração do Óleo Vegetal e Determinação do Rendimento em Óleo Fixo}

Após a secagem e definição da massa seca (MSS), as amostras de sementes foram prensadas mecanicamente a frio na prensa mecânica hidráulica laboratorial MARCONI MA-098 de 15 a 50 toneladas, com cilindro filtrante em aço inox do Laboratório de Oleaginosas da Embrapa Cerrados (Planaltina-DF).

Foi definida a massa de óleo (MO) produzido a partir da prensagem a frio das amostras, massa da torta e borra residual do filtro. Com essas informações foi definido o rendimento médio em óleo com cinco repetições de sementes maduras e mais cinco repetições de sementes 'de vez'.

A Equação 2.15 determina o rendimento em óleo fixo percentual de cada amostra. A massa seca de sementes úmidas (MSS) colocadas na prensa para extração de óleo dividido pela massa de óleo (MO) formada.

$$
\text { RdOleo }(\%)=\frac{M O}{M S S} * 100
$$

Os dados gerados neste experimento também permitiram calcular o rendimento do endocarpo e o rendimento em sementes por fruto, neste caso utilizou-se as Equações $2.12 \mathrm{e}$ 2.13 como no primeiro experimento, a diferença entre os experimentos está relacionados ao número de repetições, época de coleta dos frutos, bem como características desejadas para o aproveitamento do 'satim'. Alterou-se o tamanho da amostra inicial, o ensaio para averiguação do rendimento em óleo vegetal considerou 10 frutos secos, coletados em 
março de 2014 e o ensaio para o rendimento em 'satim' foi realizado com 27 frutos com polpa e 13 frutos com sementes viáveis, coletados em setembro de 2014.

O rendimento médio em óleo em relação ao fruto também foi calculado através da massa média em óleo (MO) gerada dividida pela massa do fruto (Mfruto), multiplicadas por cem para obter a porcentagem de óleo em relação ao fruto.

$$
\text { RdOleo }(\%)=\frac{M O}{\text { Mfruto }} * 100
$$

\subsection{6 - Extração da Folha da Piaçava Mirim do Norte da Bahia}

O levantamento das informações sobre o aproveitamento tradicional da folha da piaçava mirim foi feito por meio de levantamento descritivo, acompanhamento da extração e troca de saberes com as extrativistas da comunidade de Massarandupió, município de Entre Rios na Bahia. Os trabalhos de campo ocorreram no mês de março de 2015.

\section{5 - RESULTADOS E DISCUSSÃO}

Os principais PFNMs oriundos da palmeira da piaçava da Bahia são: fibra vegetal bruta; fibra limpa; fibra cortada; vassouras de fibra vegetal; 'fitas' para cobertura de quiosques; artesanatos da fibra vegetal; frutos para o plantio; biojóias do endocarpo dos frutos secos; óleo vegetal da semente dos frutos; polpa de 'satim'; artesanatos da folha (bolsas, esteiras, chapéus) e o palmito utilizado na alimentação tradicional quilombola e indígena.

Entre esses produtos, oriundos da piaçava da Bahia, aqueles encontrados no mercado brasileiro foram: vassouras da fibra vegetal da piaçava da Bahia (mais de seis tipos); uma grande variedade de artesanatos confeccionados com a fibra vegetal e palha da costa; bijuterias e biojóias feitas do endocarpo do fruto; venda de frutos sem o epicarpo e mesocarpo para o plantio da palmeira e exportação; a farinha de 'satim' já foi comercializada nas feiras das cidades de Ituberá e Nilo Peçanha, mas não são mais encontradas no mercado.

A COOPRAP recebeu o prêmio do SEBRAE Top 100 de artesanatos, no ano de 2012, com os artesanatos da fibra vegetal da piaçava e a palha da costa (Raphia vinifera). A Figura 41 ilustra algumas peças confeccionadas pelos artesões cooperados e independentes, residentes em Ituberá e Nilo Peçanha, artesões em sua maioria quilombolas. 


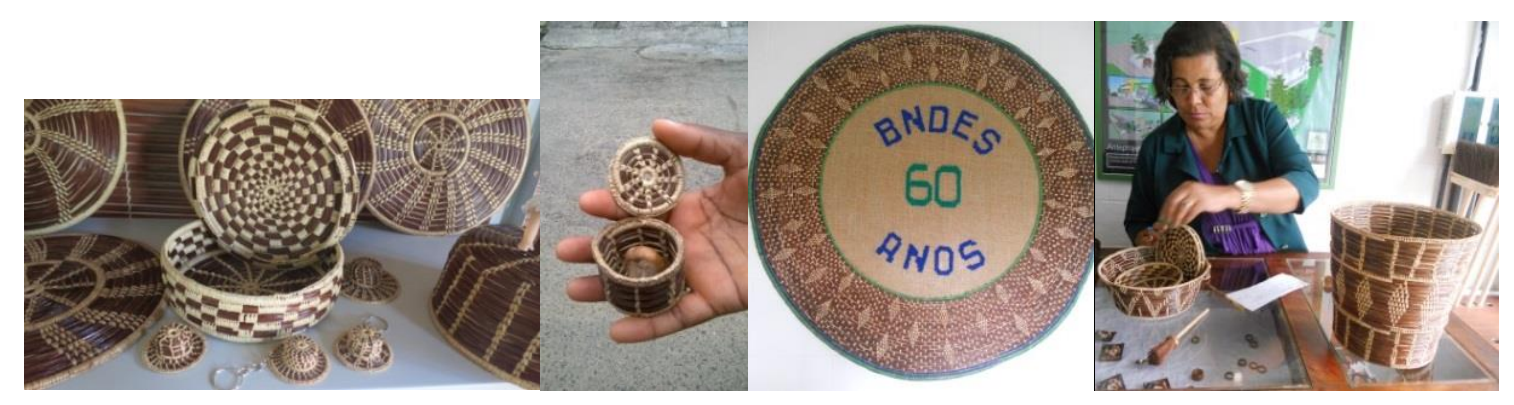

Figura 41: Artesanatos da fibra vegetal limpa da piaçava da Bahia, COOPRAP (2013).

As folhas da piaçava mirim (acaule) são transformadas em bolsas, cestos, tapetes, entre outros objetos, são intensamente comercializados nos Municípios de Mata de São João e Entre Rios além das feiras locais, regionais, nacionais e internacionais. O fluxograma da Figura 42 ilustra as possibilidades do uso integral da Attalea funifera Mart. e descreve algumas etapas do processamento e o aproveitamento destes produtos florestais. 


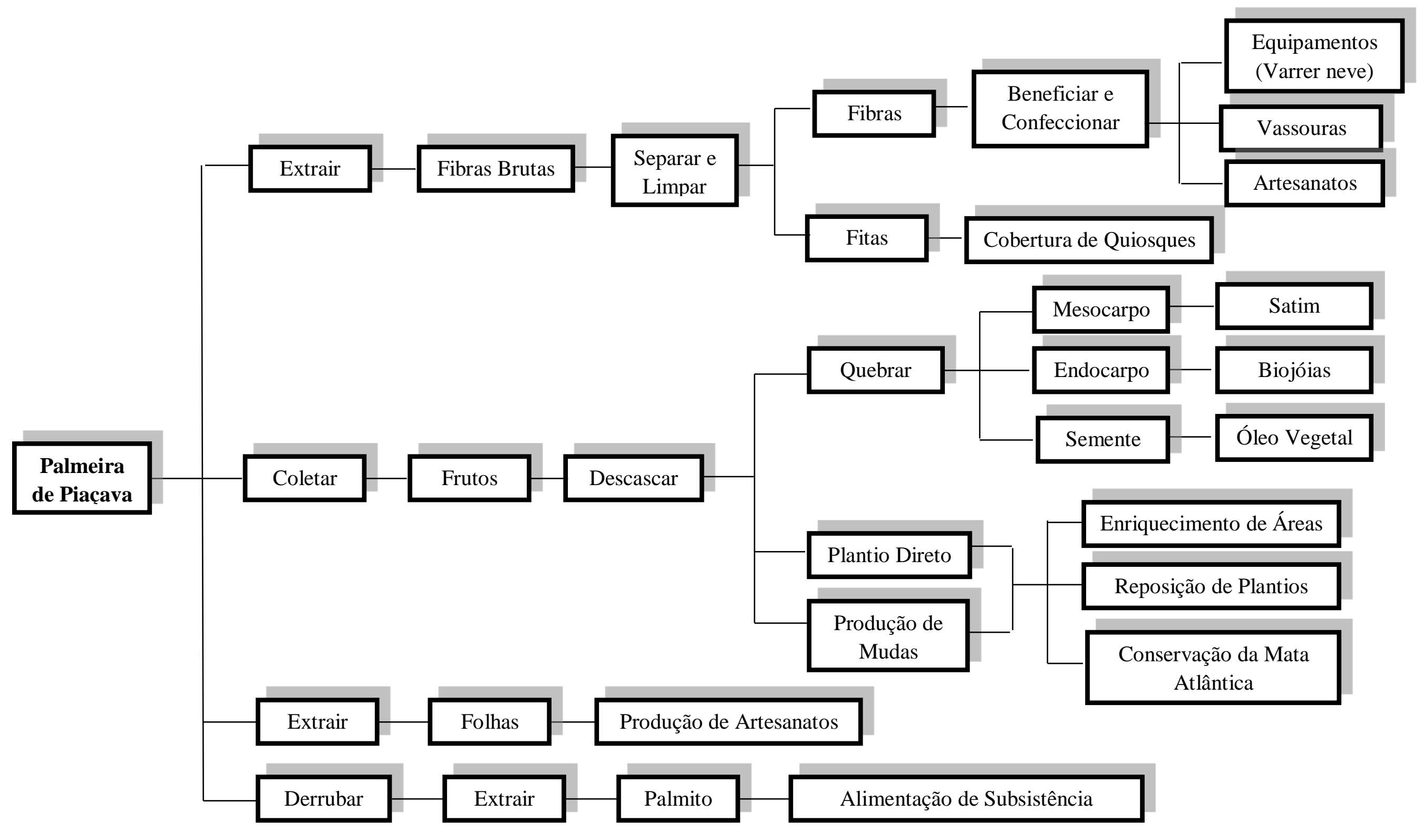

Figura 42: Fluxograma dos PFNMs oriundos da palmeira da piaçava da Bahia. 


\subsection{1 - Fibra Vegetal da Piaçava da Bahia}

As principais características da fibra vegetal é a sua resistência física, fibra maleável, impermeável, durável e encontrada em abundância no litoral sul da Bahia. As fibras de $1^{\circ}$ são aquelas que possuem maior flexibilidade, coloração avermelhada e estão presentes nas plantas que sofrem exploração de 8 a 12 messes e principalmente nas plantas em desenvolvimento, conhecidas como bananeira em produção (BP), antes de iniciar a produção de frutos. Nesta fase de desenvolvimento a planta produz pouca fibra, sempre de $1^{\circ}$ qualidade para produção de vassouras e exportação, pois são finas e menos quebradiças.

Segundo informações levantadas em campo, a fibra vegetal é considerada de primeira (tipo exportação) quando apresenta a cor avermelhada, tem uma espessura finomédia, adequada para vassouras de cepo tradicional ou de 'chita', ou seja, vassouras de uso doméstico. Essas fibras vegetais devem estar secas, sem impurezas e bem penteada (solta), inteira ou do tamanho encomendado. Em Canavieiras Ituberá e Nilo Pçenha, os informantes foram precisos ao afirmar que nas regiões de Canavieiras, Bel Monte e Nazaré é possível encontrar com facilidade fibras consideradas de $1^{\circ}$, sugerindo que as plantas dessa região passaram por uma espécie melhoramento genético.

As fibras de segunda apresentam uma cor marrom claro ou escuro, possuem espessura médio-grossa, são destinadas à confecção de vassouras de chapa, vassouras de gari e vassourões. As fibras médio/grossas são menos flexíveis do que as fibras de primeira (fino-média) e, portanto menos trabalháveis. As fibras de segunda (médio-grossa) são mais quebradiças e, quando são dobradas, rompem-se e são inutilizadas aumetando os reíduos presentes no processo produtivo.

Outra diferença entre as fibras de primeira e de segunda está relacionada com o tamanho dos fios de fibras limpas, neste aspecto, os feixes de piaçava são classificados, como sendo: fibras de primeira, aquelas com comprimento $\geq 1,20 \mathrm{~m}$; e de segunda, feixes de fibras limpas entre 0,5 a 1,0 m de comprimento. Existe ainda os pedaços de fibra curta, com comprimento de até $0,5 \mathrm{~m}$, essas, por sua vez, são oriundas dos tocos, deixados na palmeira.

As fibras das palmeiras localizadas em áreas nativas de Mata Atlântica, possuem a espessura média fina (tipo exportação) devido ao sombreamento da área e a competitividade com as outras plantas da floresta. As palmeiras mais vigorosas, com disponibilidade de sol e espaço, produzem fibras de espessuras mais grossas. As palmeiras 
menos vigorosas, tradicionalmente conhecidas por plantas 'sengas', também produzem fibras do tipo exportação.

Pelo exposto é possível observa-se que os critérios para diferenciar as fibras de primeira e de segunda, ainda não estão padronizados entre os agroextrativistas, produtores e consumidores das fibras vegetais. Esses critérios são de difícil padronização, pois se trata de um produto vegetal heterogêneo, manejado por diversos atores, utilizado para mais de um fim, caraceristcas estas que dificulta definições clares e precisas quanto ao tipo de fibra ofertado. A classificação das fibras vegetais da piaçava deve considerar a espessura, o tamanho, a fase de desenvolvimento da planta mãe, a região onde ocorreu a extração e, também as variedades genéticas presentes na região, como por exemplo a piaçava acaule (piaçava mirim) que produz uma fibra vegetal diferente da piaçava.

O processamento da fibra vegetal consiste em etapas de beneficiamento, visando, principalmente, oferecer ao mercado consumidor, sejam atravessadores, indústrias ou consumidor final, fibras vegetais dentro dos padrões de qualidade exigidos ${ }^{28}$, fibras de primeira e segunda, com presença de 'toco' ou não, em determinados tamanhos de corte e com ausência de água nas fibras.

Os equipamentos utilizados no processamento da fibra vegetal são tecnologias criadas pelos agroextrativistas, operadores e produtores da fibra. São de domínio social e especificamente os equipamentos para confecção de vassouras, grampeadora para vassouras, também denominada de "pica-pau", é comercializado por ferreiros na cidade de Feira de Santana na Bahia (Figura 43). O processo de confecção das vassouras de piaçava tem sua principal etapa à fixação das fibras vegetais no cepo de madeira, conhecida entre os produtores como "entufamento" da vassoura. Assim sendo a "entufadeira pica-pau" é acionado pelos pés do operador/extrativista, que por sua vez aciona o fixador de grampos no cepo de madeira, com as mãos ele segura as fibras, coloca o grampo no centro do furo do cepo e fixa as fibras vegetais em cada furo.

\footnotetext{
${ }^{28} \mathrm{O}$ decreto 5.739/1940 classificam as fibras de piaçava (Attalea funifera Martius e Leolpoldina piassaba Wallace) estabelecendo-se dois grupos: piaçava em molhos e piaçava cortada. Em molhos se divide em tipo 1, 2 e 3 . Tipo 1 com fibras de 3 metros; tipo 2 com fibras de 1,5 metros; tipo 3 com 0,75 metros. A fibra cortada é classificada em fina, média e grossa (ZUGAIB; COSTA, 1998 apud GUIMARÃES; SILVA, 2012).
} 


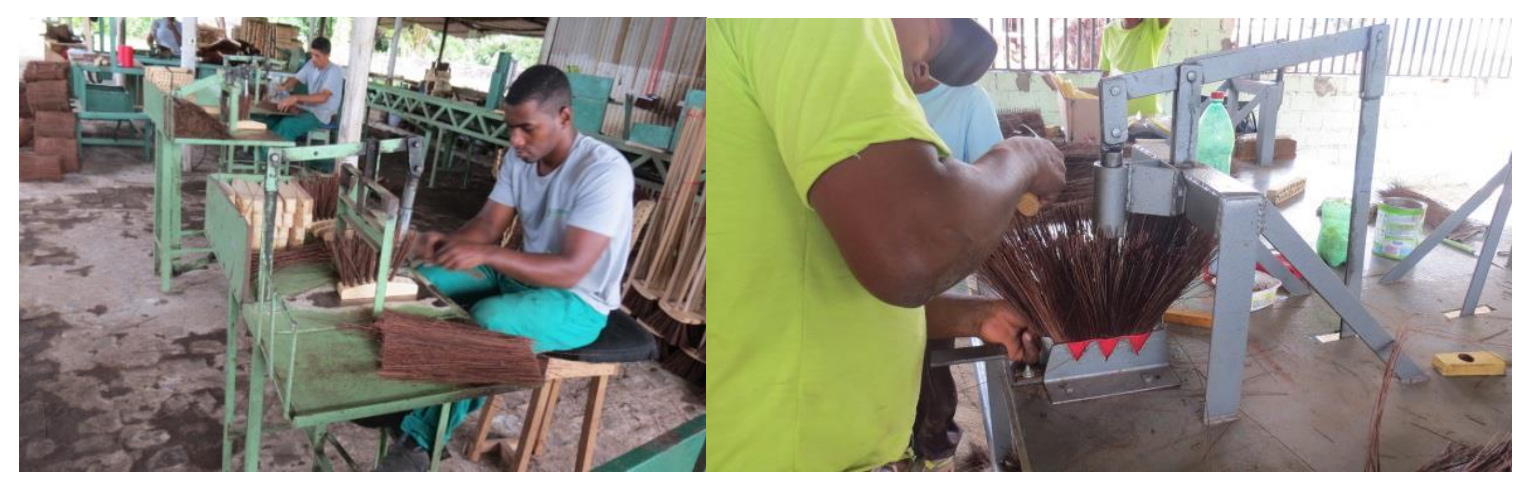

(a)

(b)

Figura 43: Grampeadora e prensa manual ou de pedal, equipamentos produzidos por ferreiros locais, unidades produtivas da (a) COOPRAP e da (b) COOPAFBASUL

Empresas como a Rossi utilizam equipamentos desenvolvidos para padronizar o produto final, diminuir o tempo de processamento e a mão de obra. Um dos equipamentos utilizados pela ROSSI (Figura 44) foi adquirido pela COOPRAP e testado pelos operadores da cooperativa. Esse equipamento foi desenvolvido para fabricar vassouras sintéticas e os insumos das vassouras sintéticas são uniformizados. Infelizmente não foi bem aceito pela equipe de operadores da COOPRAP, esses verificaram interrupções de funcionamento do equipamento durante os testes realizados, principalmente devido as diversas espessuras que a fibra vegetal da piaçava possui.

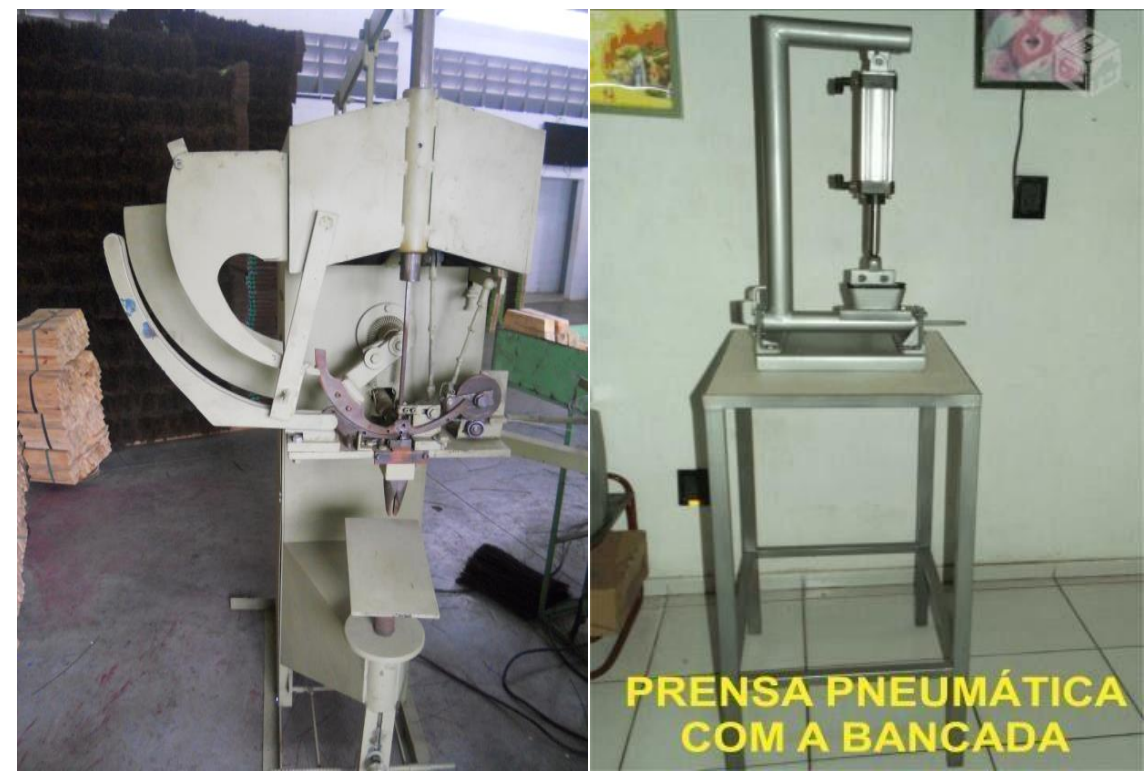

(a)

(b)

Figura 44: (a) Grampeadora automática e (b) prensa pneumática produzida pela empresa Pozzi Máquinas. Fonte: Marcado Livre. 
A grampeadora automática ficou sub-utilizada dentro da COOPRAP e os operadores mantiveram a grampeadora manual ou de pedal denominada de 'pica pau' para fixar as fibras limpas e cortadas no cepo da vassoura de piaçava.

Esse fato reforça a importância de se desenvolver tecnologias voltadas às realidades produtivas locais, juntamente com aqueles que vão utilizar as novas criações, considerar também que a redução de mão de obra por equipamentos pouco funcionais pode trazer problemas em etapas produtivas que antes da intervenção não eram consideradas gargalos para produção agroextrativista.

Entre os sistemas produtivos analisados, áquele que mais verticalizou a produção foi o galpão instalado no Quilombo Brejo Grande. Mesmo neste empreendimento, como é tradição na região a 'cata' da fibra bruta é feita em um 'catadouro' familiar dentro do quilombo e em seguida a fibra selecionada e limpa é transportada para o galpão, onde a fibra é pré-beneficiada, beneficiada e as vassouras são confeccionadas.

Os resultados deste capítulo sobre o processamento da piaçava iniciam na etapa de pré-beneficiamento até a confecção das vassouras; segue para a cadeia produtiva da fibra vegetal; as margens de ganhos dos extrativistase e o cenário dos ganhos extrativistas, com aproveitamento da fibra vegetal, supondo o domínio de todo o processo produtivo pelos quilombolas e, a inserção do seu produto no mercado consumidor. Também apresenta os rendimentos relacionados ao fruto da piaçava, uma breve descrição do processo produtivo da folha da piaçava mirim Os índices de rendimento do processamento dos frutos da piaçava para o aproveitamento alimentar e óleo vegetal foram realizados de forma experimental, considerando o saber quilombola e critérios técnicos científicos para averiguação das variáveis de interesse.

\subsubsection{1 - Pré-beneficiamento da Fibra Vegetal}

Essa etapa consiste na seleção e limpeza das fibras brutas, ou seja, principalmente na separação manual das fibras e fitas, realizado a partir do direcionamento e descolamento das fibras com auxílio do facão (Figura 45). Após esse processo, a extrativista ou 'catadeira' de fibra prepara manualmente as fibras sujas para limpeza, organiza as fibras para 'penteamento' propriamente dito. 


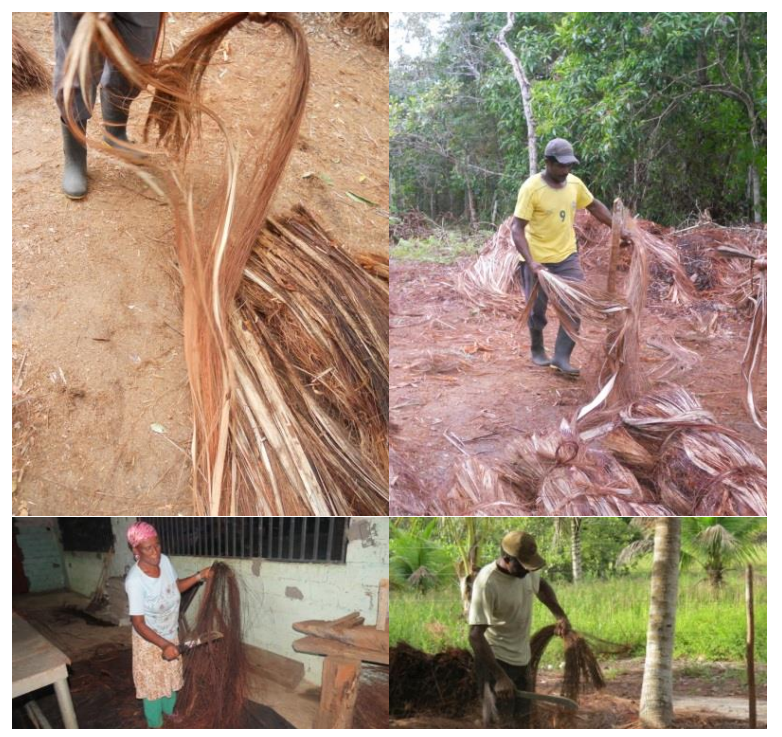

Figura 45: 'Cata' manual das fibras brutas da piaçava, Canavieiras e Ituberá, Bahia

Essa atividade é genuinamente feminina, mas os homens contribuem com a abertura dos feixes ou 'mondongos' de fibras sujas e fechamento dos 'mondongos' de fibras limpas e 'mondongos' de fitas, resultantes da separação. Porém conforme ilustrado na Figura 46 existe homens que realizam a atividade de 'cata' dentro da cadeia produtiva.

O procedimento de limpeza das fibras sujas é realizado com equipamento rústico com dentes de ferro (pregos ou ancinhos metálicos), preso a uma base de madeira, denominado localmente de 'pentes fixos' ou 'escovas', ilustrados na Figura 49.

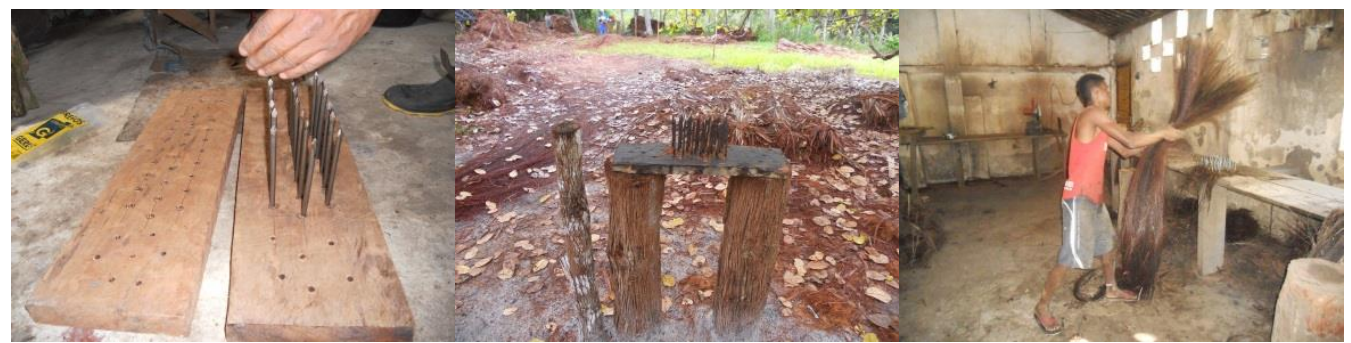

Figura 46: 'Pentes' utilizados no pré-beneficiamento da fibra bruta de piaçava.

Ressalta-se que nesta etapa de pré-beneficiamento, o 'pente' utilizado para limpeza da fibra vegetal, tem os ancinhos feitos de prego, espaçados entre si, na etapa seguinte o 'pente' utilizado possui os ancinhos metálicos mais próximos uns dos outros, promovendo uma limpeza mais profunda nas fibras vegetais.

Portanto o pré-beneficiamento, etapa de limpeza, separação e formação dos feixes de fibras e 'fitas', bem como a confecção dos pentes de 'fitas' são realizadas com excelência pelas comunidades tradicionais, envolvidas com o extrativismo da piaçava, 
principalmente por ser um trabalho manual realizado com ferramentas artesanais e de baixo impacto, ilustrados nas Figuras 45 e 46.

Os ensaios de rendimento realizados em Canavieiras, Ituberá e Nilo Peçanha, apontaram para um rendimento médio de 65,6\% em fibras limpas; formação de 17,1\% de 'fitas' e 9,8\% de resíduos mensurados (Tabela 37).

Tabela 37: Rendimentos em fibra vegetal, 'fitas', resíduo mensurado e resíduo real formado nos sistemas produtivos avaliados, etapa de pré-beneficiamento.

\begin{tabular}{|c|c|c|c|c|c|c|c|c|c|}
\hline \multirow[t]{2}{*}{ Sistema $^{29}$} & \multirow{2}{*}{$\begin{array}{c}\mathrm{N}^{\circ} \\
\text { repetiçã } \\
\mathbf{0}\end{array}$} & \multirow{2}{*}{$\begin{array}{c}\text { Massa } \\
\text { inicial } \\
(\mathrm{Kg})\end{array}$} & \multicolumn{2}{|c|}{ FIBRA (\%) } & \multicolumn{2}{|c|}{ FITA (\%) } & \multicolumn{2}{|c|}{ RESÍDUO (\%) } & \multirow{2}{*}{$\begin{array}{c}\text { RESÍDUO } \\
\text { REAL }^{30} \\
(\%) \\
\text { Rend }\end{array}$} \\
\hline & & & Rend & C.V & Rend & C.V & Rend & C.V & \\
\hline I & 14 & 4 & 67,2 & 9,1 & 15,1 & 25,9 & 11,6 & 40,3 & 17,7 \\
\hline II & 8 & 4 & 63.5 & 8.2 & 20,4 & 15.6 & 10,7 & 36,3 & 16 \\
\hline III & 5 & 7 & 66 & 6,2 & 15,9 & 13,2 & 7,2 & 14,2 & 18,1 \\
\hline \multicolumn{3}{|c|}{ Médias } & 65,6 & 7,9 & 17,1 & 18,1 & 9,8 & 30,3 & 17,3 \\
\hline
\end{tabular}

Apesar dos cuidados e acuidade dos experimentos, a massa de resíduo gerada se perde ao longo dos passos dos ensaios, por isso calculou-se o resíduo médio real formado nesta etapa, ele passa de $9,8 \%$ para $17,3 \%$, demonstrando que $7,5 \%$ de material vegetal não foram mensurados no experimento adotado.

$\mathrm{Na}$ Tabela 30 é possível observar as diferenças encontradas em cada experimento realizado (2012, 2013 e 2014), nos três diferentes sistemas produtivos, localmente denominados de 'catadouros' familiares.

O sistema I apresentou o melhor rendimento em fibras vegetais limpas e prébeneficiadas, com rendimento em 'fitas' inferior aos sistemas I e II e formação de resíduo real maior do que a média encontrada para os três sistemas. O coeficiente de variação foi superior no sistema I para o rendimento em fibras, 'fitas' e formação de resíduos, quando comparado com os sistemas II e III. Ressalta-se que o aumento na quantidade de repetições não reduziu o coeficiente de variação, mantendo o sistema III entre aqueles com menor coeficiente de variação. O sistema III foi aquele com maior formação de resíduo, fato que diretamente relacionado a uma limpeza e seleção mais apurada, necessário quando o ‘catadouro' familiar comercializa a fibra vegetal da piaçava cortada, ou seja, a fibra vegetal beneficiada. O sistema produtivo II comercializa os feixes de fibras limpas e 'fitas', nesta relação à massa $(\mathrm{kg})$ ou arrobas $(15 \mathrm{~kg})$ são mensuradas no momento da venda, observa-se

\footnotetext{
${ }^{29}$ Sistema I: AQBGI (janeiro, 2014); II: Meeiros (abril, 2013) e III: Allan (outubro, 2012).

30 A porcentagem de resíduo real foi calculado considerando os rendimentos de fibra vegetal e 'fitas' formados no processo de pré-beneficiamento.
} 
que neste sistema produtivo a formação de resíduo real foi a menor, contrastando com sistema III com maior formação de resíduo real.

O tempo mensurado nos ensaios de rendimentos está relacionado à agilidade da 'catadeira' ou 'catador' na separação entre fibra e 'fita' e, limpeza da fibra vegetal. No sistema I o experimento foi realizado por uma quilombola (mulher), no sistema II com um agroextrativista (homem) e no sistema III com dois quilombolas (homens), ou seja, neste último sistema, houve variação do operador nas 5 repetições realizadas, o que pode justificar o maior coeficiente de variação entre os três sistemas conforme Tabela 38.

Tabela 38: Média do tempo de 'cata' da fibra vegetal da piaçava.

\begin{tabular}{|c|c|c|c|c|}
\hline Sistema & $\mathbf{N}^{\circ}$ repetição & $\begin{array}{c}\text { Massa inicial } \\
(\mathbf{K g})\end{array}$ & $\begin{array}{c}\text { Tempo de Cata } \\
(\mathbf{m i n})\end{array}$ & $\begin{array}{c}\text { C.V. } \\
(\mathbf{\%})\end{array}$ \\
\hline I & 14 & 4 & 30 & 29,6 \\
\hline II & 8 & 4 & 12,4 & 10,5 \\
\hline \multicolumn{6}{|r|}{ III } & 5 & Médias & $\mathbf{2 1 , 2}$ & $\mathbf{2 0}$ \\
\hline
\end{tabular}

A média de tempo gasto na 'cata' da piaçava é de aproximadamente 21 minutos para pré-beneficiar $4 \mathrm{~kg}$ de fibra bruta e 45 minutos para transformar $7 \mathrm{~kg}$ de fibra bruta em fibra limpa. Portanto para transformar $1 \mathrm{~kg}$ de fibra bruta em fibras limpas e 'fitas', a 'catadeira' (operador) gasta em média 5,9 minutos na separação e limpeza. Infere-se destes dados que uma 'catadeira' consegue pré-beneficiar uma arroba (15 kg) de piaçava bruta, em uma hora e trinta minutos, portanto em oito horas de trabalho por dia, uma 'catadeira' tem o potencial de pré-beneficiar, aproximadamente, $81 \mathrm{~kg}$ de fibra bruta. Essa atividade normalmente é realizada pelas mulheres e filhas, em ambientes familiares, onde elas se dividem entre os compromissos domésticos e atividades de separação e limpeza das vibras brutas, por isso, a produtividade diária das 'catadeiras' é um pouco menor.

A produtividade informada pelas 'catadeiras' refere-se a quantidade de fibras limpas geradas, podendo chegar até 6 arrobas por dia por 'catadeira', ou seja, uma capacidade produtiva de até $90 \mathrm{~kg}$ de fibras limpas por dia por pessoa. O pagamento por este trabalho é feito considerando o valor da fibra limpa, ou seja, o produto final após o pré-beneficiamento $(\mathrm{R} \$ 8,00$ por arroba de fibra limpa).

Além do domínio da técnica deve-se considerar o volume da fibra vegetal bruta e limpa, tanto no transporte quanto na formação dos feixes, sendo estes os fatores que demandam tempo e esforço. A formação dos feixes ou fardos é conhecida localmente como 'amarrio dos mondogos', conforme mencionado na etapa de manejo florestal. Neste sentido é importante ressaltar que os feixes de piaçava bruta, pesam entre 60 a $80 \mathrm{~kg}$, e 
após a 'cata' os feixes com fibras limpas são novamente fechados, esses também são formados com grandes volumes, para facilitar o posterior transporte do produto, apesar de elevar o esforço do agroextrativista.

\subsubsection{2 - Beneficiamento de Fibra Vegetal}

A etapa de beneficiamento da piaçava consiste na reabertura dos fardos limpos de piaçava, nova seleção e divisão das fibras conforme sua espessura e comprimento. Os equipamentos utilizados na etapa de beneficiamento são os 'pentes' para limpezas e ajustes nas direções das fibras e a guilhotina para cortar as fibras nos comprimentos requeridos. Também são utilizados facão, machadinha, balança e pequenas ferramentas para manutenção e ajustes dos equipamentos.

Os cortes das fibras limpas são feitos com a guilhotina, tanto pode ser manual como elétrica, essa última gera gastos adicionais com energia, mas traz eficiência ao processo, devido à rapidez e a qualidade final do corte (Figura 46). Os cortes variam entre $37 \mathrm{~cm} ; 32$ $\mathrm{cm}, 24 \mathrm{~cm}$ e $13 \mathrm{~cm}$ de comprimento.

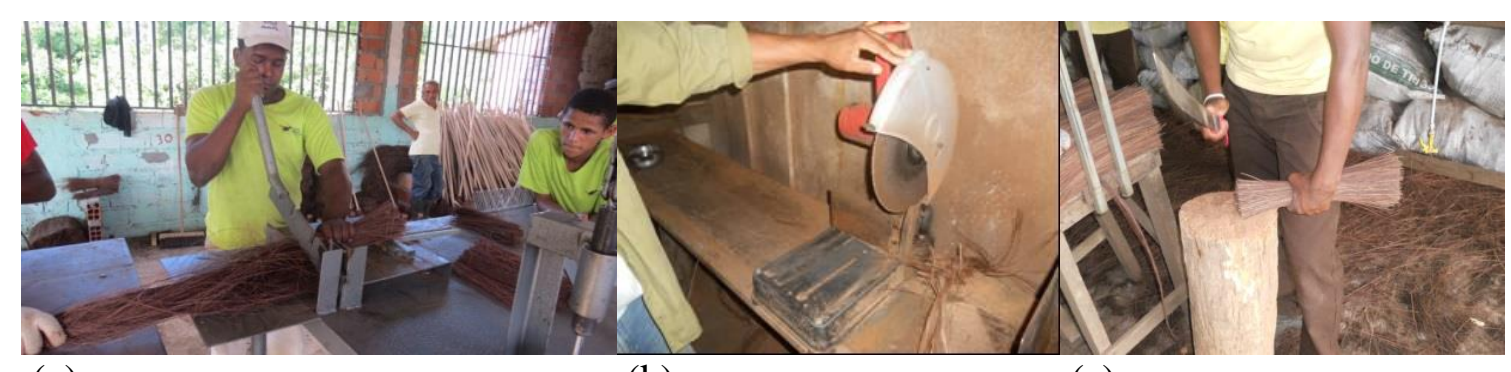

(a)

(b)

(c)

Figura 46: Equipamentos de corte da fibra: (a) guilhotina manual, (b) elétrica e (c) facão.

As fibras são selecionadas entre fino-médias, grosso-médias e grossas, as duas primeiras espessuras são aproveitadas para confecção das vassouras de piaçava, as fibras grossas são descartadas, pois, se utilizadas, provocam a ruptura ao serem dobradas e fixadas no cepo da vassoura (Figura 47). 


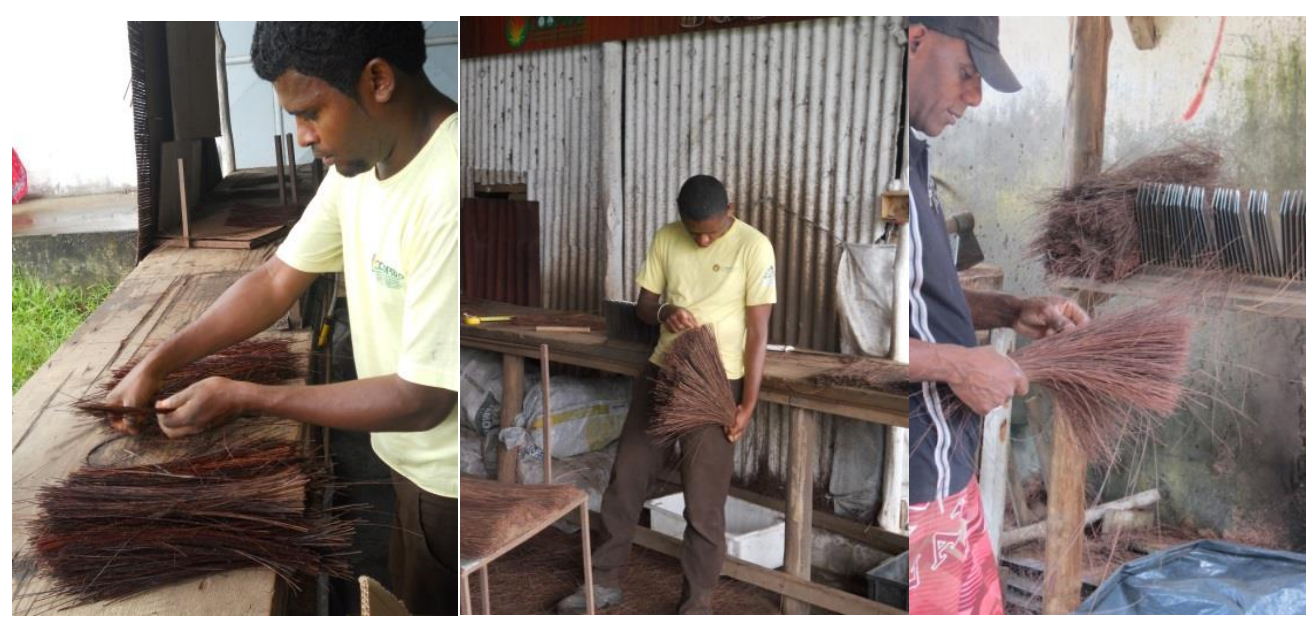

Figura 47: Seleção manual das fibras finas, médias e grossas na COOPRAP (Nilo Peçanha) e 'catadouro do Hamilton (Ituberá).

Novas limpezas são necessárias para retirada de resíduos e direcionamento das fibras selecionadas para confecção das vassouras. Esses 'pentes fixos' ou 'escovas' possuem seus dentes de ferro mais próximos, tornando essa segunda limpeza da fibra vegetal mais aprimorada, com capacidade de retirar impurezas menores (Figura 48). Esse equipamento é constantemente utilizado no processamento da fibra, inclusive após a confecção da vassoura de piaçava para reorganizar as fibras e retirar resíduos ainda presentes.

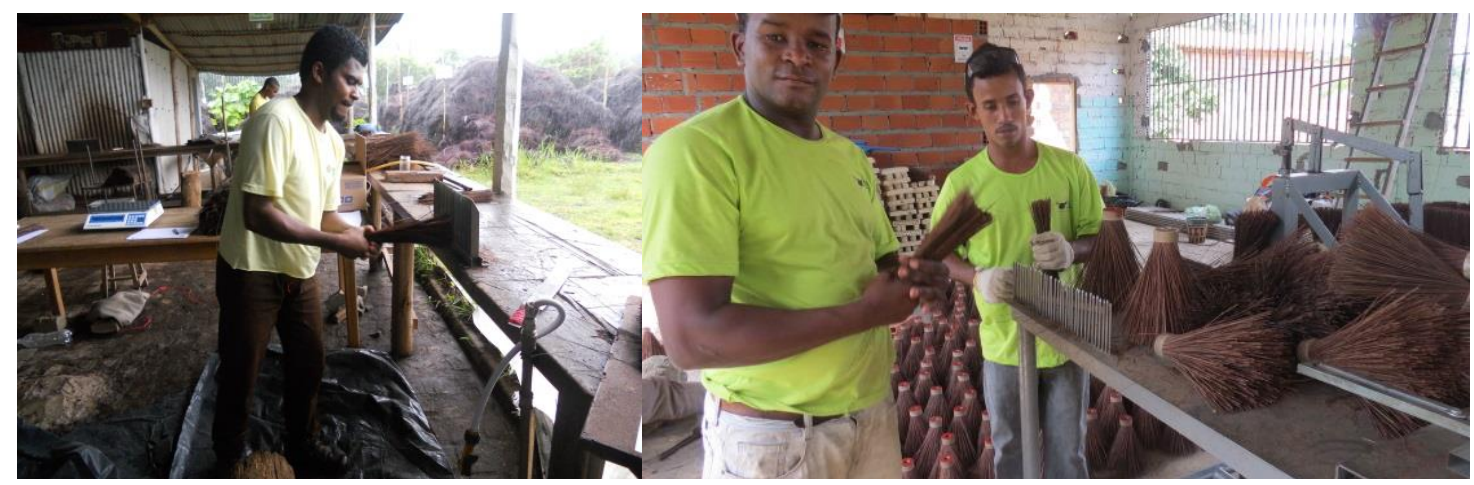

Figura 48: 'Pentes metálicos' utilizados no beneficiamento da fibra limpa da piaçava.

Os três sistemas produtivos analisados na etapa de beneficiamento foi o 'catadouro do Hamilton' (março, 2014); AQBGI (abril, 2013); ambos no município de Ituberá e 'catadouro do Alan'(outubro, 2012) em Nilo Peçanha na Bahia. Neste estudo denominados sistemas IV; III e I, respectivamente.

O sistema I executava a etapa de confecção das vassouras de piaçava e comercializa com a COOPAFABASUL; o sistema III vende as fibras vegetais cortadas aos 
atravessadores de fora do estado da Bahia; e o sistema IV fornecia fibra cortada a COOPRAP. Essas fibras foram comercializadas nas seguintes dimensões:

- Sistema Produtivo I: $30 \mathrm{~cm} ; 24 \mathrm{~cm}$ e $13 \mathrm{~cm}$;

- Sistema Produtivo III: $37 \mathrm{~cm} ; 24 \mathrm{~cm} ; 20 \mathrm{~cm}$;

- Sistema Produtivo IV: $32 \mathrm{~cm} ; 24 \mathrm{~cm} 15 \mathrm{~cm}$.

Observem que todos esses sistemas I, II e IV foram encontrados na região de Ituberá e Nilo Peçanha, são iniciativas de grupos de extrativistas que vislumbram melhores ganhos com a fibra vegetal, em todos esses três sistemas, as fibras brutas são compradas de outros extrativistas ou produtores da região. Nestes casos os extrativistas envolvidos com o corte da fibra limpa possuem áreas familiares com piaçavas, mas optam por comprar as fibras brutas.

Em Canavieiras o corte das fibras vegetais limpas ocorre nos galpões ou armazéns, nestes locais os funcionários ganham por produção, os donos compram fibras brutas e/ou limpas dos médios e grandes produtores da região e, repassam as fibras cortadas aos atravessadores para serem comercializadas em outras regiões.

Considerando os três sistemas produtivos analisados, os ensaios de rendimento apontaram uma média aproximada de 73,2 \% de fibras limpas e cortadas; e a formação de aproximadamente $26,8 \%$ resíduos na etapa de beficiamento da fibra vegetal da piaçava, conforme Tabela 39.

Tabela 39: Rendimentos em fibra vegetal cortada e resíduo real formado nos sistemas produtivos I, III e IV, etapa de beneficiamento.

\begin{tabular}{|c|c|c|c|c|c|c|c|}
\hline \multirow[t]{2}{*}{ Sistema $^{31}$} & \multirow{2}{*}{$\begin{array}{c}\mathbf{N}^{\circ} \\
\text { repetição }\end{array}$} & \multirow{2}{*}{$\begin{array}{c}\text { Massa } \\
\text { inicial } \\
(\mathrm{Kg})\end{array}$} & \multicolumn{2}{|c|}{ FIBRA } & \multicolumn{2}{|c|}{ RESÍDUO } & \multirow{2}{*}{$\begin{array}{c}\text { RESÍDUO } \\
\text { REAL }^{32} \\
\text { Rend. } \\
(\%)\end{array}$} \\
\hline & & & $\begin{array}{c}\text { Rend. } \\
(\%)\end{array}$ & $\begin{array}{l}\text { C.V } \\
\text { (\%) }\end{array}$ & $\begin{array}{c}\text { Rend. } \\
(\%)\end{array}$ & $\begin{array}{l}\text { C.V } \\
\text { (\%) }\end{array}$ & \\
\hline I & 8 & 2 & 61,3 & 12,4 & 38 & 21,6 & 38,7 \\
\hline III & 5 & 4,7 & 89,5 & 10,8 & 3,7 & 33,8 & 10,5 \\
\hline IV & 14 & 3 & 68,9 & 68,9 & 26,5 & 15,5 & 31,1 \\
\hline \multicolumn{3}{|c|}{ Médias } & 73,2 & 30,7 & 22,7 & 23,6 & 26,8 \\
\hline
\end{tabular}

O sistema III apresentou maior rendimento em fibra limpa e cortada, com 89,5\% de fibras vegetais comercializáveis, o sistema IV com $68,9 \%$ e o sistema I com rendimento de $61,3 \%$ de fibras vegetais cortadas, observa-se que o sistema III e IV são 'catadouros'

\footnotetext{
${ }^{31}$ Sistema I: AQBGI (Abril, 2013); III: Alan (outubro, 2012) e IV: Hamilton (março, 2014)

${ }^{32}$ A porcentagem de resíduo real foi calculado considerando os rendimentos de fibra vegetal e 'fitas' formados no processo de pré-beneficiamento.
} 
familiares e, neste caso, adotam a venda das fibras limpas e cortadas, após a formação dos feixes. A diferença entre os dois está relacionada às exigências do comprador das fibras vegetais cortadas, o sistema III comercializa seu produto com atravessadores de fora da região e o sistema IV é cooperado da COOPRAP. Esses atravessadores pagam menos por um produto de qualidade inferior, ou seja, fardos de fibras cortadas de espessuras indesjadas, bem como presença de outras impurezas. O sistema I realiza o beneficiamento e repassa as fibras cortadas para o sitema VI realizar a confecção das vassouras de piaçava, a AQBGI é parceira da COOPAFBASUL.

Nesta etapa de beneficiamento da fibra vegetal para obtenção da fibra cortada (tipo exportação), observa-se que o aumento no número de repetições, adotado nos experimentos realizados, não representou a diminuição no coeficiente de variação da variavél rendimento em fibra vegetal (Tabela 39). O que indica que as variações apresentadas, entre as repetições, está inerente a heterogenidade presente nas amostras de fibras vegetais. Os feixes de fibras limpas, processados nos experimentos (amostras), foram comprados pelos extrativistas beneficiadores de diferentes áreas de extração, podendo ser oriundos de palmeiras de diversas fases de desenvolvimento.

O tempo de seleção e corte foi mensurado para cada um dos três sistemas, o maior coeficiente de variação foi encontrado no sistema III que teve mudança no operador no momento das análises. O tempo de corte de $1 \mathrm{~kg}$ de fibra vegetal limpa é de 11,2 minutos (Tabela 40), esse valor equivale a 2 horas e 48 minutos para beneficiar $15 \mathrm{~kg}$, mais os tempos de preparo para o corte (12 minutos/15 kg), em três horas, um operador tem capacidade produtiva de beneficiar em média $15 \mathrm{~kg}$ ou uma arroba de fibra limpa. Portanto em um dia de trabalho, oito horas diária, o operador consegue cortar aproximadamente duas arrobas e meia $(37 \mathrm{~kg} / \mathrm{dia} / \mathrm{pessoa})$.

Tabela 40: Média do tempo de seleção e corte da fibra vegetal da piaçava

\begin{tabular}{|c|c|c|c|c|c|}
\hline $\begin{array}{c}\text { Experimento/ } \\
\text { Sistema }\end{array}$ & $\mathbf{N}^{\circ}$ repetição & $\begin{array}{c}\text { Massa inicial } \\
(\mathbf{K g})\end{array}$ & $\begin{array}{c}\text { Tempo de Corte } \\
(\mathbf{m i n})\end{array}$ & $\begin{array}{c}\text { C.V. } \\
(\mathbf{\%})\end{array}$ & $\begin{array}{c}\text { Temp. Corte } \\
\mathbf{1 k g}(\mathbf{m i n})\end{array}$ \\
\hline I & 8 & 2 & 31,25 & 27,4 & 15,8 \\
\hline III & 5 & 4,7 & 39,4 & 39,2 & 8,4 \\
\hline IV & 14 & 3 & 28,1 & 15,4 & 9,4 \\
\hline \multicolumn{5}{|c}{ Média } \\
\hline
\end{tabular}

Os índices de rendimento aqui apresentados referem-se ao extrativista que não ganha por produção e sim pela quantidade comercializada, esse trabalhador normalmente é dono do seu próprio 'catadouro familiar'. Esses valores diferem dos índices de produtividade dos trabalhadores que recebem por produção, neste caso especifico, essa 
etapa do processamento é comumente realizada no galpão ou armazém local. Outra possibilidade de caminho para a fibra vegetal beneficiada, consiste na venda direta da fibra vegetal às fabricas de confecção das vassouras de piaçava. Segundo informações dos operadores de corte da fibra vegetal, os trabalhadores que recebem por produção, podem atngir uma produção máxima de até 5 arrobas/dia/pessoa de fibra cortada.

\subsubsection{3 - Confecção das Vassouras de Piaçava}

A confecção de vassouras de piaçava consiste na fixação das fibras vegetais no cepo, no cano de PVC das vassouras redondas, na chapa ou plástico e argola para vassoura de pia. A vassoura de cepo utilizam grampos para aderir às fibras nos furos da madeira, as vassouras de chapa de plástico e alumínio, são pressionadas e presas nestes materiais (Figura 49).

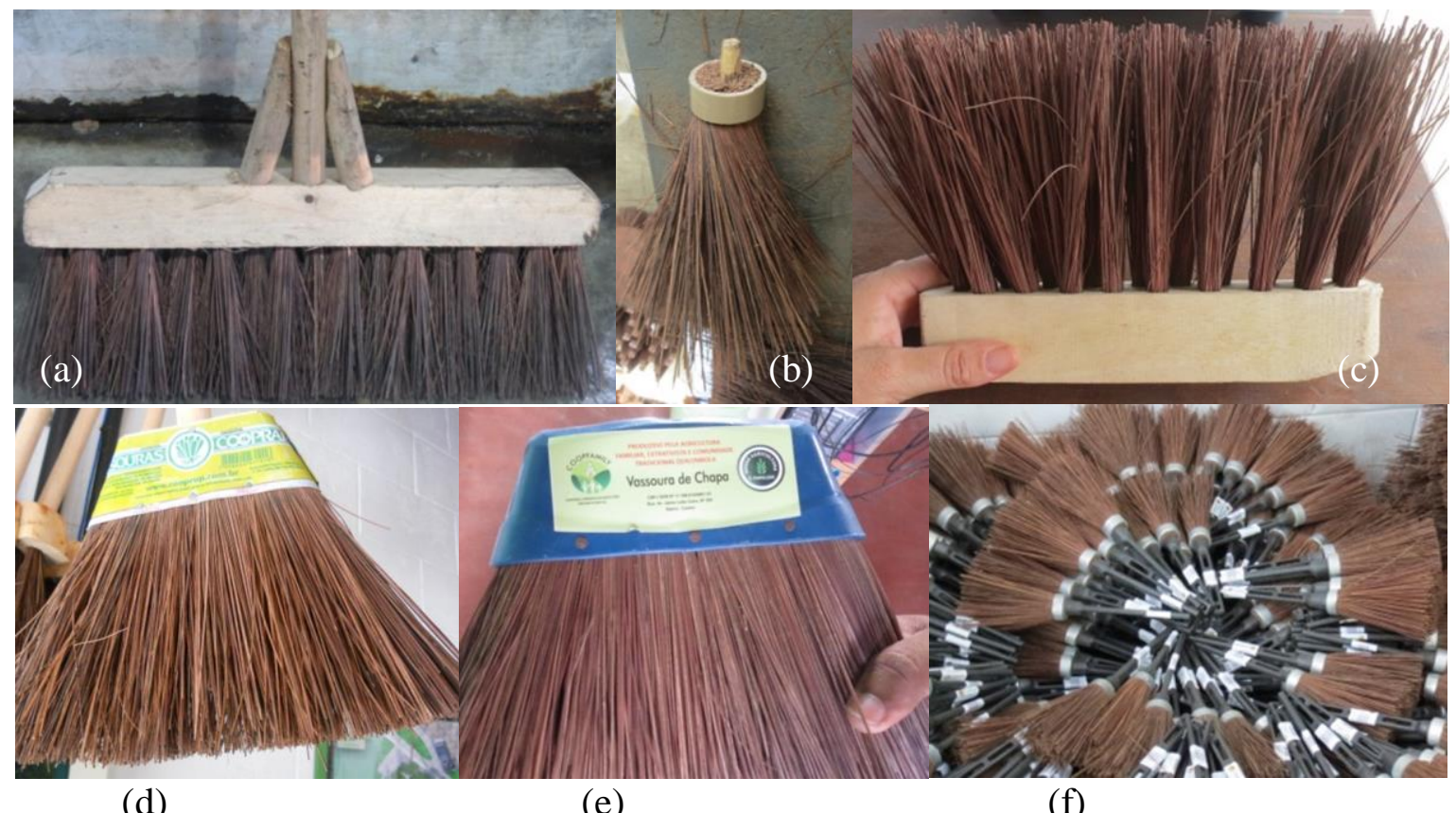

(d)

(e)

(f)

Figura 49: (a) Vassourão de cepo de madeira; (b) vassoura redonda; (c) vassoura de chita de cepo em madeira, (d) vassoura de chapa de alumínio e (e) plástico; e (f) vassouras de pia. Todas confeccionadas com a fibra vegetal da piaçava.

Os experimentos realizados para averiguar o processo de confecção das vassouras de piaçava, V(a), V(b) e VI, iniciaram com as fibras limpas e cortadas a $32 \mathrm{~cm}$, utilizadas na fabricação de vassouras de cepo de madeira, também denominada de 'vassoura de chita', de uso doméstico, produto comercializado com 18 e/ou 22 furos de fixação da fibra vegetal. 
Essa etapa inicia com abertura dos feixes de fibras cortadas e limpas, faz-se a classificação das fibras em fibra fino-médias, grosso-médio e o descarte de fibras vegetais fora do padrão (novos resíduos). As fibras fino-médias passam por novas limpezas e são fixadas no cepo, pelo operador, com a grampeadora manual ou máquina 'pica-pau' (Figura $50)$.

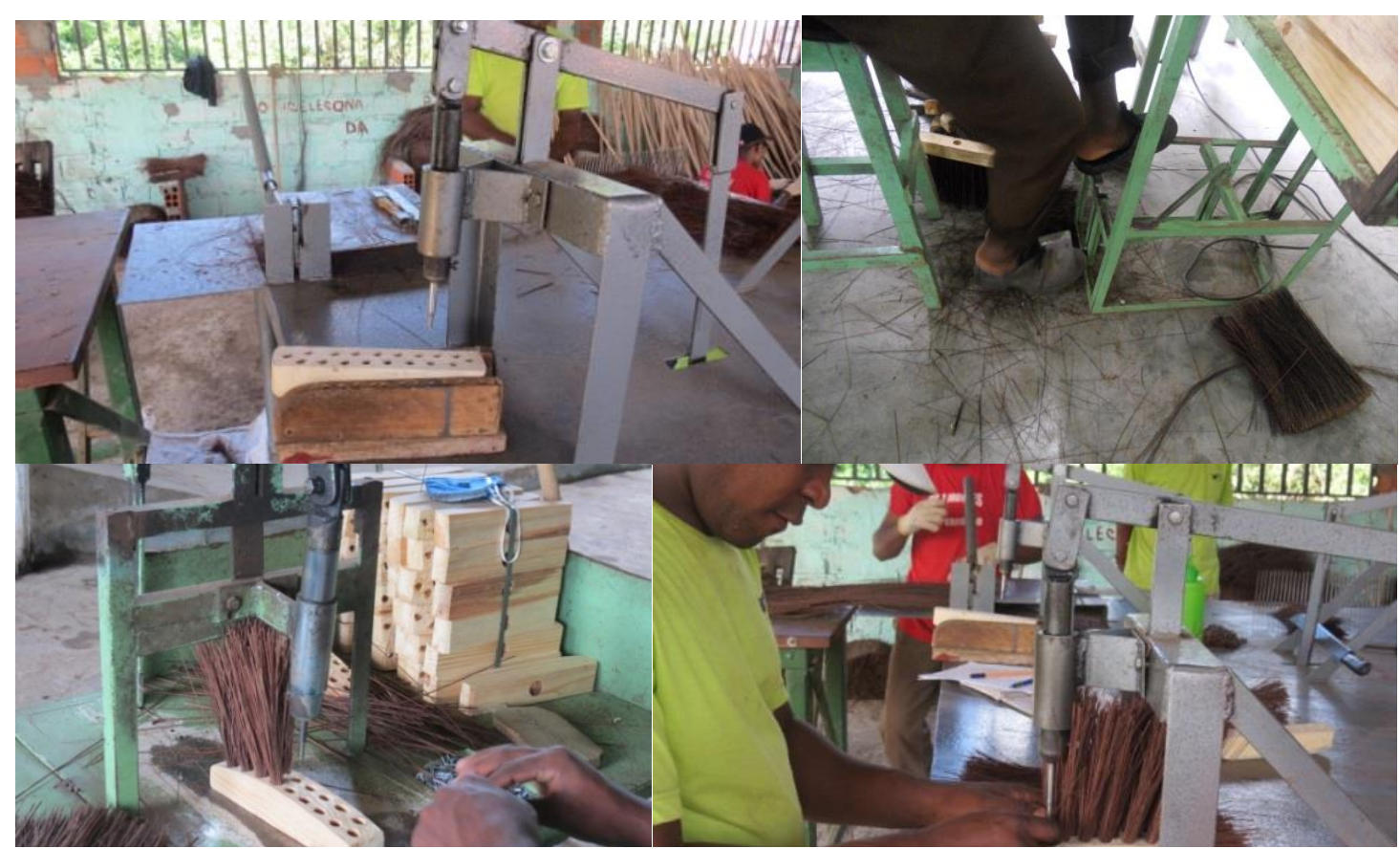

Figura 50: Máquina para fixar a fibra vegetal no cepo da vassoura, denominada de grampeadora ou 'pica-pau'.

Durante esse procedimento o operador faz novas seleções das fibras que compõem o maço de fibras que será fixado em cada furo das vassouras, produzindo um pouco mais de fibras grossas e resíduos. Esses 'tufos' ou maços de fibras são selecionados de forma manual por cada operador da grampeadora, no momento do 'entufamento', o operador A apresentou uma média de $6 \mathrm{~g} /$ furo e o operador B 9,5 g/furo, o equivalente a uma média de 7,75 g/furo da vassoura de cepo com 18 furos.

$\mathrm{Na}$ etapa de confecção das vassouras de cepo de 18 furos, observou-se que as fibras grosso-médias representam $11,5 \%$ das fibras selecionadas para confecção das vassouras de uso doméstico. A retirada das fibras grosso-médias são de suma importância, pois quando usadas na confecção da vassoura de uso doméstico com 18 furos, as fibras podem se romper. A Figura 51 ilustra como fica o 'tufo' (molho) de fibras beneficiadas, que são descartadas, devido ao rompimento da fibra vegetal. Os vassourões de limpeza urbana possuem furos maiores e, por isso, os fabricantes dos vassourões misturam as fibras 
grossas com as médias para confecciona-los, sem prejuízo de qualidade do produto final e elevando o aproveitamento das fibras vegetais beneficiadas.

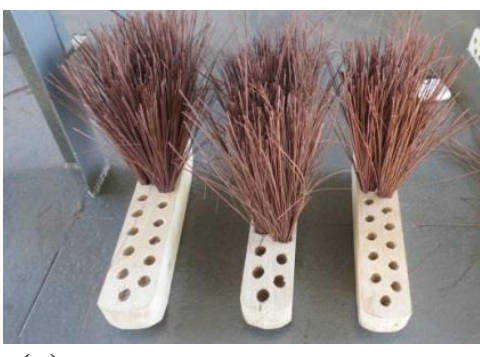

(a)

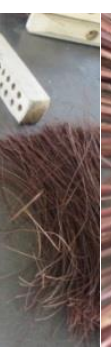

(b)

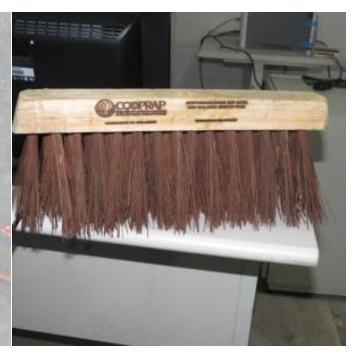

(c)

Figura 51: (a) Vassouras de cepo de madeira com 18 furos; (b) 'tufo' de fibras quebradas; e (c) vassourão da piaçava da Bahia com fibras grossas.

As vassouras redondas (Figura 51b) de uso tradicional na Bahia são confeccionadas sem a necessidade de dobras, as fibras são fixadas sob pressão, com um anel metálico ou de plástico. Essas vassouras também permitem a utilização das fibras grossas e o seu uso é para limpeza de áreas externas e quintais.

Nesta etapa de confecção das vassouras de cepo de madeira (uso doméstico) as fibras comercializáveis são aquelas fino-médias, selecionadas e, limpas pelos operadores, após a abertura dos feixes de fibras limpas e cortadas. O rendimento médio de fibras finamédio, considerando os três sistemas avaliados, foi de $74 \%$ de aproveitamento de fibras vegetais cortadas, gerou um resíduo real médio de aproximadamente 15,3\% na etapa de confecção de vassouras (Tabela 41).

Tabela 41: Rendimentos em fibra vegetal fino-média, resíduo mensurado e resíduo real formado nos sistemas produtivos avaliados, etapa de confecção.

\begin{tabular}{|c|c|c|c|c|c|c|c|c|c|c|}
\hline \multirow[t]{2}{*}{ Sistema $^{33}$} & \multirow[t]{2}{*}{$\begin{array}{c}\mathbf{N}^{\circ} \\
\text { repetição }\end{array}$} & \multirow{2}{*}{$\begin{array}{l}\text { Massa } \\
\text { inicial } \\
(\mathrm{Kg})\end{array}$} & \multicolumn{2}{|c|}{$\begin{array}{l}\text { FIBRA FINO- } \\
\text { MÉDIA }\end{array}$} & \multicolumn{2}{|c|}{$\begin{array}{c}\text { FIBRA } \\
\text { GROSSA }\end{array}$} & \multicolumn{2}{|c|}{ RESÍDUO } & \multicolumn{2}{|c|}{$\begin{array}{l}\text { RESÍDUO } \\
\text { REAL }\end{array}$} \\
\hline & & & $\begin{array}{c}\text { Rend } \\
(\%)\end{array}$ & $\begin{array}{l}\text { C.V } \\
(\%)\end{array}$ & $\begin{array}{l}\text { Rend } \\
(\%)\end{array}$ & $\begin{array}{l}\text { C.V } \\
(\%)\end{array}$ & $\begin{array}{c}\text { Rend } \\
(\%)\end{array}$ & $\begin{array}{l}\text { C.V } \\
(\%)\end{array}$ & $\begin{array}{c}\text { Rend } \\
(\%)\end{array}$ & $\begin{array}{l}\text { C.V } \\
(\%)\end{array}$ \\
\hline Va & 14 & 2 & 76 & 10,9 & 11 & 76,9 & 10,8 & 29,7 & 10 & 27,6 \\
\hline $\mathbf{V b}$ & 5 & 3 & 71 & 17,3 & 12 & 72,3 & 1.6 & 29,4 & 13 & 96,8 \\
\hline VI & 8 & 1,2 & 75 & 17,9 & & & 5,6 & 28,6 & 23 & 58,3 \\
\hline & Médias & & 74 & 15,3 & 11,5 & 74,6 & 6 & 29,2 & 15,3 & 45,6 \\
\hline
\end{tabular}

O sistema produtivo $\mathrm{Va}$ (março, 2014) apresentou $76 \%$ de rendimento em fibras comercializáveis (fino-média), valor superior do o sistema produtivo $\mathrm{Vb}$ (outubro, 2012) com $71 \%$ de aproveitamento das fibras fino-médias. Essa diferença encontrada dentro da

\footnotetext{
${ }^{33}$ Sistema Va: COOPRAP (março, 2014); Vb: COOPRAP (outubro, 2012) e VI: COOPAFABASUL (abril, 2013).
} 
COOPRAP justifica-se pelos critérios exigidos na compra das fibras cortadas, transferindo o aumento de resíduo à etapa anterior, beneficiamento da fibra vegetal (corte), como foi possível observar sistema IV, onde aproximadamente $31 \%$ da fibra limpa cortada se transforma em resíduo. O sistema VI apresentou uma média de $75 \%$ de fibras comercializáveis (fino-média) e $23 \%$ de resíduos reais formados nesta etapa de confecção das vassouras.

Considerando a massa de fibras fino-médias cortadas e limpas formadas e o numero de vassouras geradas em cada ensaio de rendimento é possível afirmar que $1 \mathrm{~kg}$ de fibras fino-médias geram em média aproximadamente 6,22 vassouras de cepo de 18 furos. A média de rendimento de vassouras por quilo de fibras médio-finas variou entre os sistemas, no sistema VI um quilo de fibras fino-médias gerou 4,78 vassouras e no sistema V(a) um quilo de fibras fino-médias gerou 8,68 vassouras, apresentou um coeficiente de variação na ordem de $34,6 \%$ (Tabela 42).

Tabela 42: Quantidade média de vassouras por sistema produtivo analisado

\begin{tabular}{|c|c|c|c|c|c|}
\hline $\begin{array}{c}\text { Experimento/ } \\
\text { Sistema }\end{array}$ & $\mathbf{N}^{\circ}$ repetição & $\begin{array}{c}\text { Massa inicial } \\
(\mathbf{K g})\end{array}$ & $\begin{array}{c}\text { Massa Fibra } \\
\text { Fino-Média }\end{array}$ & $\begin{array}{c}\mathbf{N}^{\circ} \\
\text { Vassoura }\end{array}$ & $\begin{array}{c}\mathbf{N}^{\circ} \text { Vassoura } \\
\text { por 1 kg }\end{array}$ \\
\hline Va & 14 & 2 & 1,52 & 13 & 8,68 \\
\hline Vb & 5 & 3 & 2,16 & 11 & 5,19 \\
\hline VI & 8 & 1,2 & 0,9 & 4 & 4,78 \\
\hline \multicolumn{7}{r}{} & & Média & $\mathbf{6 , 2 2}$ \\
\hline \multicolumn{7}{r|}{} \\
\hline
\end{tabular}

Segundo informações levantadas junto aos gestoes e administradores da COOPAFBASUL, um quilo de fibra vegetal fino-média gera 4 vassouras de cepo tradicional ou chapa ou redonda; e um quilo gera 2 vassouras de gari ou vassourões.

Conforme análise dos dados coletados, é possível afirmar que cada vassoura de cepo de madeira com 18 furos, necessita de aproximadamente 160 gramas de fibras finomédias de piaçava para sua confecção. Valor muito próximo ao que a COOPRAP adota nas suas análises do custo de produção, ou seja, 164 gramas por vassoura de cepo tradicional.

Em uma hora de trabalho, cada operador consegue produzir 9,5 vassouras de cepo com 18 furos (Tabela 43), então para confeccionar 6,22 vassouras, a partir de fibras limpas e cortadas, o operador necessitará em média 39,3 minutos de trabalho. 
Tabela 43: Tempo de confecção das vassouras de cepo com 18 furos

\begin{tabular}{|c|c|c|c|c|c|}
\hline $\begin{array}{l}\text { Experimento/ } \\
\text { Sistema }\end{array}$ & $\mathbf{N}^{\circ}$ repetição & $\mathbf{N}^{\circ}$ Vassouras & $\begin{array}{c}\text { Tempo de } \\
\text { Confecção (min) }\end{array}$ & $\begin{array}{l}\text { C.V. } \\
(\%)\end{array}$ & $\begin{array}{c}\mathbf{N}^{\circ} \text { vassouras/ } \\
\text { horas }\end{array}$ \\
\hline Va & 14 & 13 & 59,6 & 19,8 & 13,0 \\
\hline $\mathbf{V b}$ & 5 & 11 & 64,2 & 25,3 & 10,3 \\
\hline VI & 8 & 4 & 46,9 & 26,7 & 5,1 \\
\hline \multicolumn{5}{|c|}{ Média } & 9,5 \\
\hline \multicolumn{5}{|c|}{ C.V. \% } & 42,6 \\
\hline
\end{tabular}

A produtividade média diária dos operadores é de 72 vassouras de cepo por dia, em um modelo produtivo onde o operador recebe as fibras limpas e separadas, separa os pequenos molhos e fixa as fibras no cepo de madeira, repassando a vassoura para mais limpezas e aparos nas fibras para posterior armazenamento. Neste caso deve-se considerar mais um operador para apoio na consolidação dessas 72 vassouras, ou seja, a produtividade de um operador é de 36 vassouras por dia. Para produzir essas 36 vassouras é necessário aproximadamente $6 \mathrm{~kg}$ de fibras fino-médias.

A produtividade média informada pelos extrativistas é bem similar a produtividade média encontrada nos experimentos realizados, aproximadamente 60 vassouras por operador por dia, neste caso, o operador só desenvolve essa atividade ao longo do dia.

\subsubsection{4 - Rendimento Total do Processo Produtivo da Fibra Vegetal}

As perdas de fibra vegetal da piaçava, aqui apresentadas, referem-se à todas as etapas da cadeia produtiva da piaçava da Bahia, desde do pré-beneficiamento até a confecção das vassouras de piaçava. Destaca-se que somente não foi mensurado as perdas do arraste das fibras brutas da mata até as vias de acesso mais próximas (transporte interno), bem como possíveis perdas no transporte e armazenamento das fibras vegetais brutas. As análises ora apresentadas, referem-se ao processamento das fibras vegetais brutas, armazenadas em galpões ou unidades familiares.

A etapa com menor formação de resíduo é o pré-beneficiamento da fibra vegetal, pois é aproveitado o subproduto gerado deste processo, a 'fita' para cobertura de quiosques. A etapa de beneficiamento, limpeza, seleção e corte da fibra vegetal, mensurados nos empreendimentos I, III e VI, apresentaram a maior média de geração de resíduos, devido, principalmente ao grau de exigências do mercado comprador e o descarte das fibras grossas.

Os experimentos realizados apontaram que na etapa de pré-beneficiamento o rendimento em fibras limpas é de $65,6 \%$; sendo formados $17,3 \%$ de 'fita' e $17,3 \%$ de 
resíduo. No beneficiamento o rendimento em fibras limpas e cortadas foi de $73,2 \%$ e a formação de resíduos 26,8\%. Na etapa de confecção de vassouras as fibras fino-médias representaram $74 \%$ das amostras analisadas, $11,5 \%$ representam as fibras grossa-médias, e com a formação de $15,3 \%$ de resíduo.

$\mathrm{Na}$ análise integrada desses indíces, considerando no pré-beneficiamento a 'fita' como um subproduto gerado e, na etapa de confecção das vassouras, as fibras grossomédias como aproveitáveis, apresenta-se o rendimento final do processamento dos PFNMs oriundos da fibra vegetal da piaçava (Tabela 44). A partir das de fibras brutas iniciais, 35,6\% são transformadas em fibras fino-médias, $17 \%$ dessa massa inicial corresponde ao subproduto 'fitas', 5,3\% corresponde as fibras grosso-médias e 41,8\% é o total de resíduos formados ao longo do processamento da fibra vegetal de piaçava.

Tabela 44: Rendimento final do processamento da fibra vegetal em vassoura de piaçava.

\begin{tabular}{|c|c|c|c|c|}
\hline & \multicolumn{3}{|c|}{ RENDIMENTO DO PROCESSAMENTO \% } \\
\hline PODUTOS & $\begin{array}{c}\text { PRÉ- } \\
\text { BENEFICIAMENTO }\end{array}$ & BENEFICIAMENTO & $\begin{array}{c}\text { CONFECÇÃO } \\
\text { VASSOURA }\end{array}$ & $\begin{array}{c}\text { TOTAL } \\
\text { ACUMULADO }\end{array}$ \\
\hline $\begin{array}{c}\text { FIBRA FINO- } \\
\text { MÉDIA }\end{array}$ & 65,6 & 73,2 & 74 & 35,6 \\
\hline $\begin{array}{c}\text { FIBRA GROSSO- } \\
\text { MÉDIA }\end{array}$ & - & - & 11,5 & 5,3 \\
\hline FITAS & 17 & - & - & 17 \\
\hline RESÍDUOS & 17,3 & 26,8 & 15,3 & 41,8 \\
\hline
\end{tabular}

A COOPRAP (2013) considerava 35\% de perdas na etapa de confecção das vassouras de piaçava, sendo esta estimativa a utilizada na definição de custos do seu processo produtivo. Os gestores e líderes da cooperatva afirmaram que na etapa de corte (beneficiamento) as perdas eram aproximadamente de 50\%, porém, atualmente esses valores são embutidos no custo de produção dos fornecedores (cooperados) das fibras coratdas (beneficidas). Estimam que o rendimento do processo produtivo como um todo está em torno de $37,33 \%$.

Os coeficientes técnicos apresentados pela COOPAFBASUL, com relação aos rendimentos do processo produtivo e, formação de resíduos nos três galpões são: etapa de pré-beneficiamento apresenta $10 \%$ de resíduo, $20 \%$ de 'fita' e $70 \%$ de fibra limpa; etapa de beneficiamento forma-se $12 \%$ de resíduo.

Moreau (1997) estimou que o percentual de desperdício nas indústrias, que trabalham com esta fibra, é da ordem de 20\%. Savastano Jr.; Pimentel (2000) afirmram que na etapa de limpeza e penteamento (pré-beneficiamento) das fibras vegetais perde-se cerca 
de $30 \%$ do material e, que estes são queimados ao ar livre. Além dos materiais que são descartados na etapa de confecção das vassouras.

Os experimentos realizados no ambito desta pesquisa, apontam que a etapa de confecção das vassouras de piaçava é a etapa que apresenta a menor quantidade de resíduos formados $(15,3 \%)$, a etapa com maior produção de resíduos é o beneficiamento (corte) da fibra veegtal da piaçava $(26,8 \%)$, o pré-beneficiamento apresentou a formação de proximadamente $(17,3 \%)$ de resíduo, informações sintetizadas na Tabela 44 já mencionada.

A partir das informações geradas nesta pesquisa, elaborou-se equações para uso na rotina dos empreendimentos que processam a fibra vegetal bruta da piaçava. Para tanto, o agroextrativista ou produtor que quiser saber a massa de fibra fino-média (MFF), a massa de fibra vegetal que será aproveitada na confecção de vassouras de cepo de uso doméstico, deve multiplicar a massa fibra bruta (MFB) pelo índice de rendimento da fibra vegetal fino-média. A equação abaixo foi elaborada para faciliatar o cálculo da massa de fibra vegetal fino-média da piaçava da Bahia.

$$
\operatorname{MFF}(\mathrm{kg})=M F B * 0,36
$$

$$
\begin{aligned}
& \text { Em que: } \\
& \text { MFF = massa de fibra vegetal fino-média }(\mathrm{kg}) \\
& \mathrm{MFB}=\text { massa de fibra vegetal bruta inicial }(\mathrm{kg})
\end{aligned}
$$

Considerando que as fibras grosso-médias também são aproveitadas na confecção das vassouras de limpeza urbana, vassouras de chapa e vassouras tradicionais (redondas), a massa de fibras grosso-médias (MFG) pode ser obtida pela seguinte equação:

$$
M F G(k g)=M F B * 0,05
$$

\section{Em que:}

$$
\begin{aligned}
& \text { MFG = massa de fibra vegetal grosso-média }(\mathrm{kg}) \\
& \mathrm{MFB}=\text { massa de fibra vegetal bruta inicial }(\mathrm{kg})
\end{aligned}
$$

Considerando que as 'fitas' também são comercializadas no mercado local, regional e nacional, são matéria-primas para construção e coberturas de quiosques, apresenta-se uma equação para calcular a massa 'fita' (MF) pela seguinte equação: 


$$
M F(k g)=M F B * 0,17
$$

\section{Em que:}

$\mathrm{MF}=$ massa de 'fita' $(\mathrm{kg})$

$\mathrm{MFB}=$ massa de fibra vegetal bruta inicial $(\mathrm{kg})$

Essas informações são relevantes para compreensão do sistema produtivo integrado, onde as etapas produtivas conversam entre si e os gargalos ficam mais evidentes, contribuindo para que os próprios atores locais, possam fazer modificações de pequena monta no processo produtivo para elevar o aproveitamento das fibras vegetais. Esses índices de rendimento são considerados nas análises de margem de ganhos dos extrativistas da fibra da piaçava.

O armazenamento das fibras brutas em campo é feito ao ar livre; as fibras limpas são armazenadas em feixes 'mondongos' no pátio nos galpões e em alguns 'catadouros'; e as fibras cortadas são fechadas por arroba e tamanhos de cortes (13, 26, 28, 30 e $40 \mathrm{~cm})$ secas e sob estrados (Figura 52). As vassouras sem os cabos são organizadas umas sob as outras, formando uma grande coluna com cada tipo de vassouras e, as vassouras com cabo são empilhadas juntas, em dúzia, prontas para comercialização ou são suspensas sob um alambrado com os cepos invertidos, evitando umidade, poeira e o ataque de cupins.

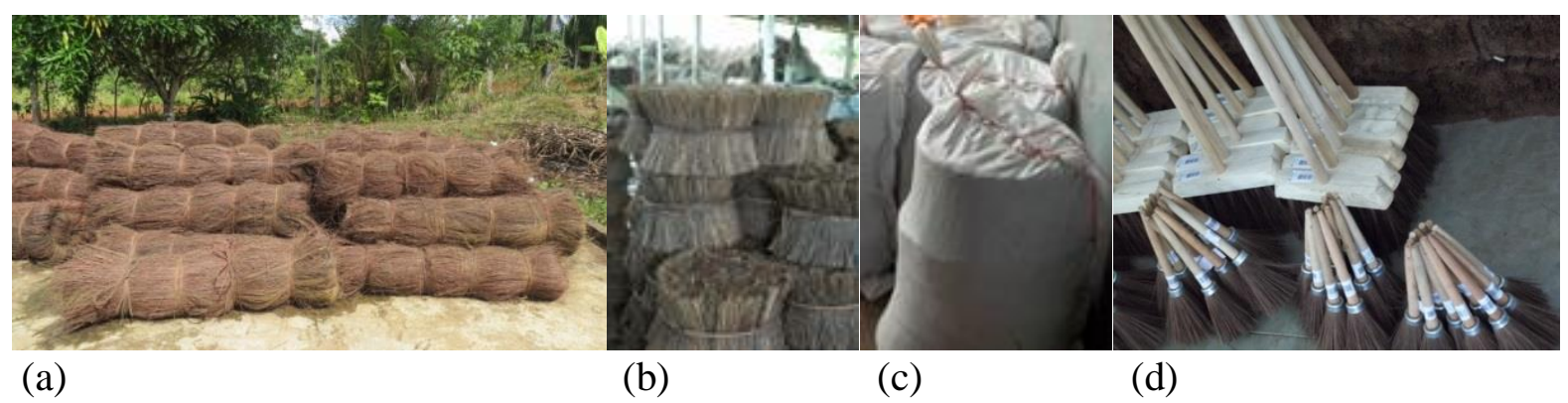

Figura 52: (a) Feixes de fibra vegetal limpa; (b) feixes de fibras cortadas; (c) fibras cortadas e embaladas e (d) vassouras de pia e vassourões de piaçava, armazenadas nas unidades produtivas.

Algumas vassouras recebem uma embalagem de plástico furada que cobre o cepo para evitar poeiras ou outras contaminações, nesse formato também são encontradas nas prateleiras dos supermercados, conforme Figura 53. 


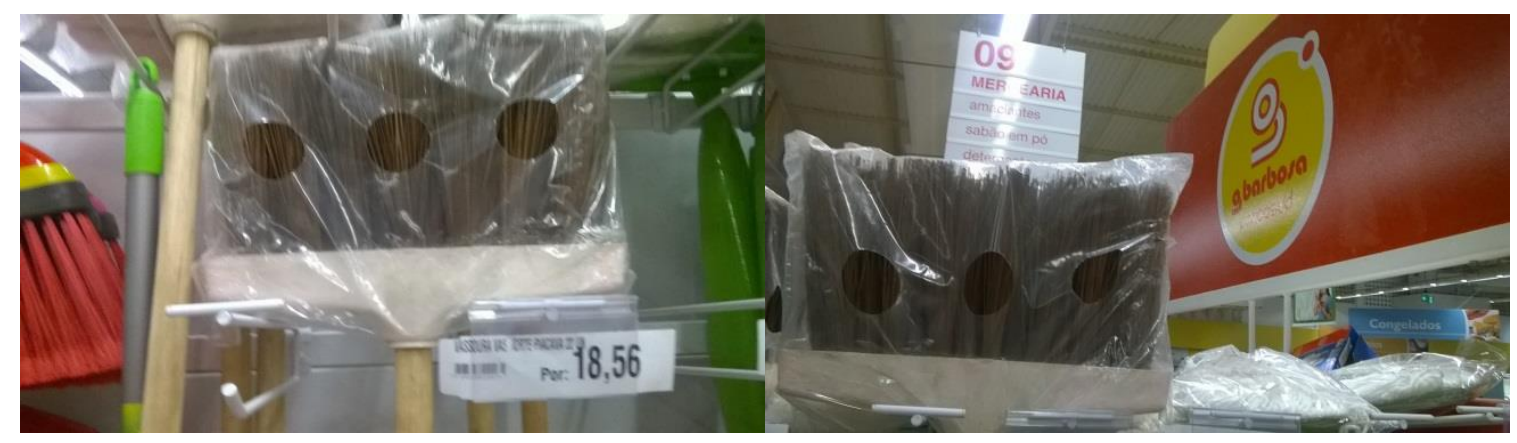

Figura 53: Vassoura de cepo de plástico para limpeza urbana, comercializada nas redes de supermercados de Aracaju, Sergipe (2014).

A comercialização das vassouras de piaçava é intensa no nordeste brasileiro, destinadas ao uso doméstico, limpeza urbana e industrial, essas vassouras são ofertadas em pequenos e grandes estabelecimentos comerciais. O principal gargalo encontrado é a concorrência com as vassouras de fibras sintéticas que são ofertadas a um preço mais acessível ao consumidor final. As fibras sintéticas são homogêneas, produzidas em larga escala, com menor custo de produção, dificultando ainda mais a concorrência da fibra vegetal.

\subsection{2 - Cadeia Extrativista da Fibra Vegetal da Piaçava}

Como já foi dito a piaçava é o quinto produto florestal não madeireiro do Brasil em valor de produção, entretanto, nos últimos anos o volume de fibra vegetal produzida e comercializada vem diminuindo, conforme os dados oficiais do IBGE, em contra ponto os preços da fibra bruta vêm melhorando. A melhora no preço pode está atribuída à política de garantia de preço mínimo para piaçava executada pelo governo federal (CONAB). Todos os extrativistas, produtores e demais atores da cadeia produtiva da piaçava, consultados, foram unânimes em afirmar que atualmente a oferta é maior que a demanda por fibra vegetal.

Esse grande volume de produção é alcançado devido à presença de grandes produtores, proprietários de extensas áreas nativas e plantadas, outra parcela da produção é destinada aos médios produtores e pequenas áreas pertencentes aos demais agroextrativistas. Esses pequenos produtores quilombolas e os agricultores familiares são responsáveis por pequena parcela desse volume produzido e registrado pelo IBGE. No entanto, é importante destacar que os agroextrativistas são responsáveis pela extração de 
todo esse volume de fibra produzida na Bahia e, parte desse volume também é prébeneficiado localmente pelos extrativistas tradicionais e agroextrativistas.

Técnicos agrícolas e extensionistas de Ituberá, afirmaram que 30\% das áreas com piaçava estão sob domínio dos quilombolas e agroextrativistas familiares, outros $20 \%$ pertencem aos médios produtores e os 50\% restantes pertencem as propriedade dos grandes produtores da região. O mapeamento das áreas com a piaçava da Bahia e os respectivos proprietários ainda não foi realizado, mesmo considerando a ocorrência restrita da espécie florestal. No anexo II consta os mapas com as áreas de ocorrência, apresentados nas literaturas disponíveis.

Em uma análise da produção de fibra bruta e a variação dos preços, nos municípios de Nilo Peçanha, Ituberá e Canavieiras, entre os anos de 2004 a 2013 é possível observar uma queda contínua (Figura 54) na quantidade de fibras brutas comercializadas no período.

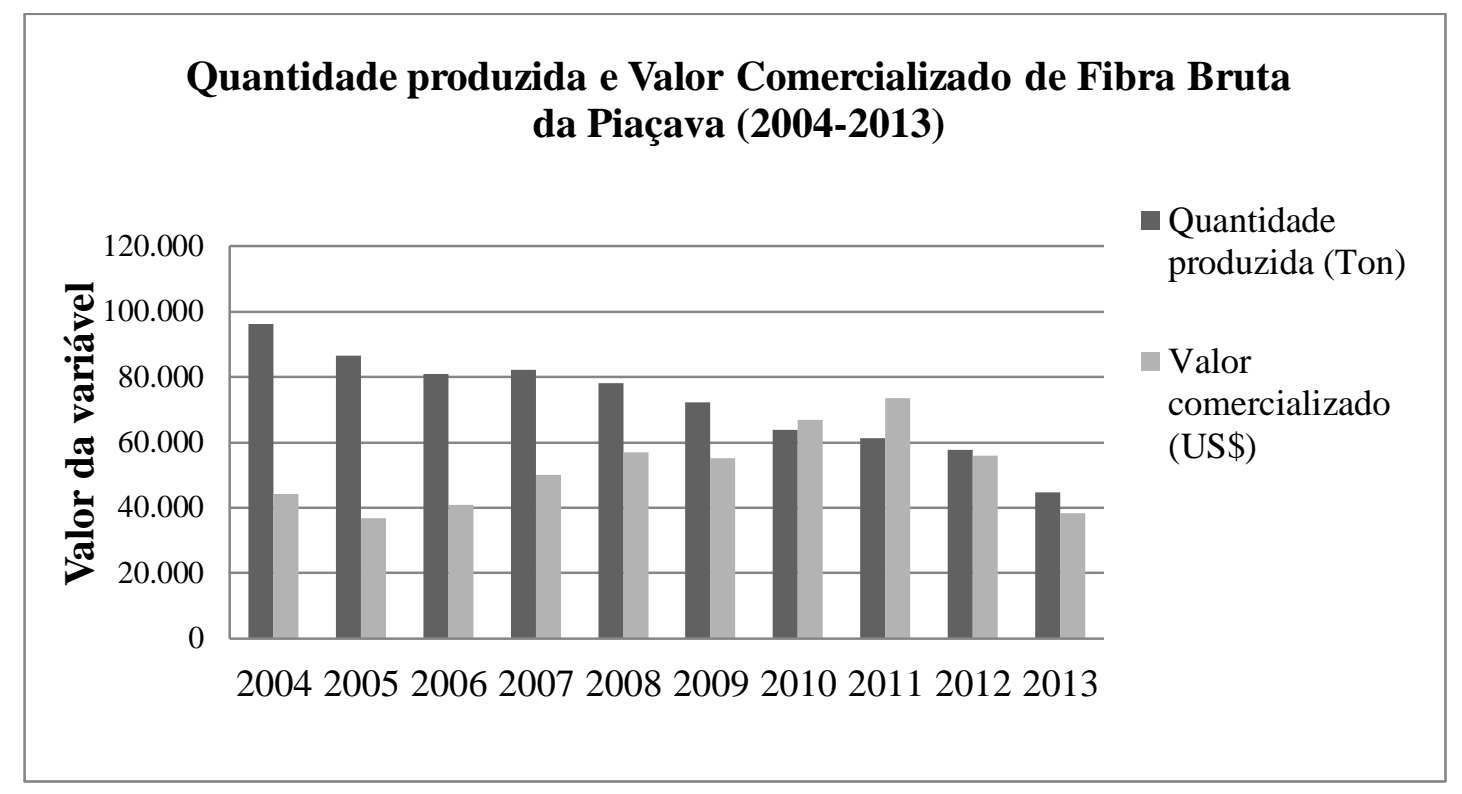

Figura 54: Quantidade produzida e valores comercializados em dólar (US\$) nos municípios de Ituberá, Nilo Peçanha e Canavieiras. Fonte: IBGE (2004-2013).

Quanto às variações do preço pago pelo quilo $(\mathrm{kg})$ de fibra vegetal bruta, observouse uma queda entre 2004 e 2005 de 8,7\% no preço final do quilo da fibra de piaçava, conforme (Figura 55). E depois uma retomada no aumento preço da fibra bruta entre o período de 2006 até 2011, com aumento de 140\% no valor do quilo da piaçava, se utilizarmos com base os US\$ 0,50 (R\$ 1,09) pagos no ano de 2006. A partir de 2012 os preços pagos por quilo da fibra bruta da piaçava vem caindo pregressivamente, chegando ao valor de US\$ 0,97/kg ( R \$ 1,89) no ano de 2012 e de US\$ 0,86/kg (R\$ 1,86) em 2013, essa queda representa $28,33 \%$ no valor final por quilo, tendo como base os US\$1,20/kg 
( $\mathrm{R}$ \$ 2,02) pagos no ano de 2011. O período de 2010 a 2013, compreende os anos em que os agroextrativistas acessaram a subvenção da piaçava, dentro da política de garantia preço mínimo - PGPM promovida pelo Governo Federal através da Companhia Nacional de Abastecimento - CONAB, onde o valor oferecido pela arroba da fibra bruta da piaçava deveria ser de no mínimo R $\$ 25,00$ (US\$ 11,54) no ano de 2013 e, o preço local que estava sendo praticado era de aproximadamente R\$20,00 (US\$ 9,26) para arroba de fibra suja. Então a cada arroba vendida, com nota fiscal, o agroextrativista poderia receber até $\mathrm{R} \$$ 5,00 (US\$ 2,31) da CONAB como garantia do preço mínimo na região.

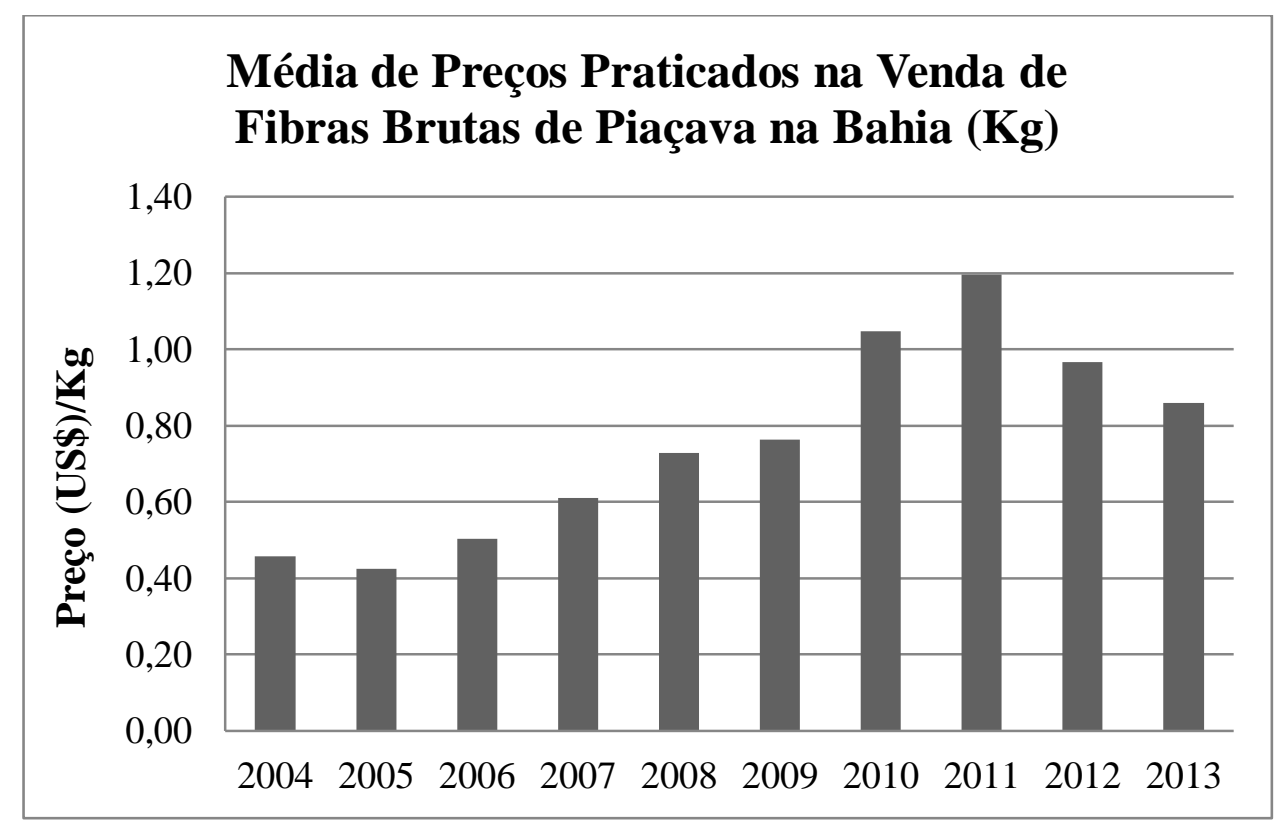

Figura 55: Quantidade de fibra bruta produzida e valores comercializados em dólar (US\$) nos municípios de Ituberá, Nilo Peçanha e Canavieiras. Fonte: IBGE (2004-20013)

O APL da Piaçava, costa Sul da Bahia (Figura 36), teve grande adesão de agroextrativistas. No entanto, entre os anos de 2011 a 2013, quando os agroextrativistas, junto com as associações e cooperativas locais foram empedidos de acessar os recursos da subvenção, devido a problemas de prestação de contas e dificuldades de escoamento da produção, a produção ocilou. Situação que continua sem solução até o momento e, os dados mostram que o preço da fibra bruta apresenta uma tendência de queda após este evento.

A exportação das fibras vegetais cortadas da piaçava da Bahia é uma realidade desde da época do descobrimento. Essas são utilizadas para fazer escovões e equipamentos para varrer neve e, segundo o IBGE em 2007, foram exportados um total de $189.840 \mathrm{~kg}$ de fibra vegetal, sendo os principais paises compradores de fibra a Alemanha, Belgica, 
Espanha, França, Holanda, Itália, Portugal e Reino Unido. Em 2014 foram exportados $116.181 \mathrm{~kg}$ de fibras para Alemanha, Belgica, Itália, Portugal e Reino Unido. Os valores anuais comercializados nas operações de exportação da piaçava estão expressos na Figura 56.

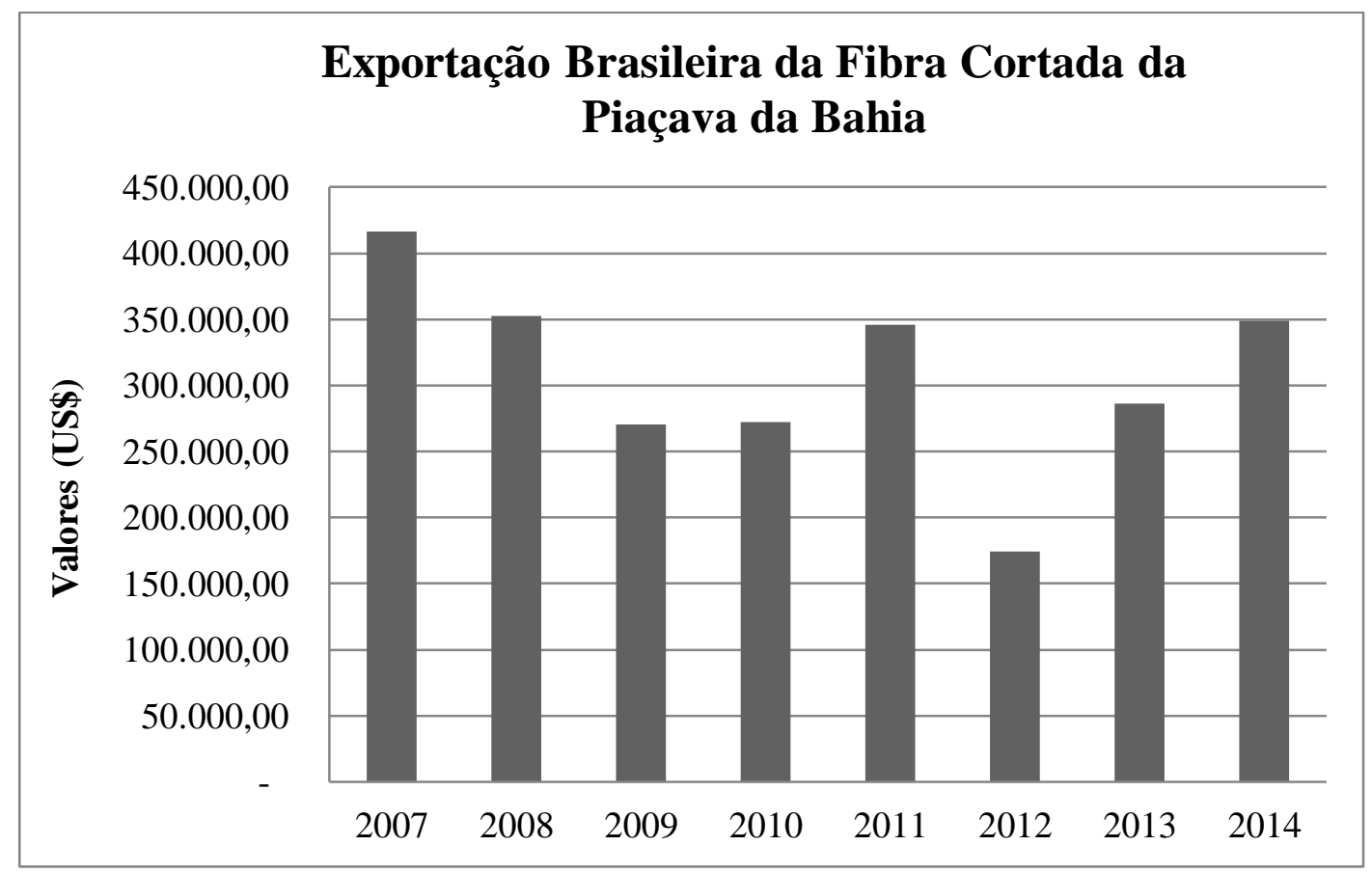

Figura 56: Valores em dólar (US\$) da exportação da fibra vegetal, via Salvador, Bahia, nos anos de 2007 a 2014. Fonte: ALICEWEB, 2015.

O ano de 2007 foi o que apresentou o maior valor de exportação e, com um total de mais de US\$ 416.000,00 ( $\mathrm{R} \$ 811.200,00)$ comercializados de fibra de piaçava cortada. $\mathrm{O}$ ano de 2012, com US\$ 174.591,00 (R\$ 304.452,45) se apresenta com o menor valor comercalizado nas exportações de piaçava cortada, no período que compreende a série entre 2007 a 2104. O ano de 2013 houve uma aumento de 64\% dos valores comercializados com exportações de piaçava, em relação ao ano anterior. E no ano de 2014 o aumento foi de $22 \%$ em relação ao ano de 2013 , com um total comercalizado de US\$ 348.661,00 ( $\mathrm{R} \$ 819.353,35)$, o segundo maior valor realizado na série histórica (20072014). No período observa-se o aumento dos volumes de importação de piaçava Alemnanha e Belgica em contrapartida a diminuição dos valores anuais importados pela Itália.

O preço praticado da fibra vegetal cortada da piaçava, no período que compreende os anos de 2007 a 2014, iniciou no valor US\$2,19/kg ( R \$ 4,27/kg) em 2007, apresentado baixa de preço nos anos seguintes (2008 e 2009). A recuperação dos preços de exportação ocorreu no ano de 2010, fato que ajudou o mercado para exportação da fibra cortada de 
piaçava da Bahia. Mesmo com uma pequena queda em 2011, os preços se estabilizaram e, novamente, apresentaram alta nos anos de 2012 e 2013, sendo estes os melhores preços alcançados, até hoje, com exportação de fibra cortada de piaçava, comercializada por US\$ $3,47 / \mathrm{kg}(\mathrm{R} \$ 6,77 / \mathrm{kg})$ e US\$2,26/kg ( $\$$ 4,88/kg ), respectivamente. Em 2014 o preço do $\mathrm{kg}$ da piaçava apresentou ligeira queda, no entanto, não saiu da casa dos US\$3,00/kg (R\$ $7,05 / \mathrm{kg}$ ) de fibra cortada.

A cadeia produtiva da fibra de piaçava se caracteriza por vários atores, com alto grau de divisão de tarefas entre os extrativistas, presença de atravessadores que compram a fibra bruta, fibra pré-beneficiada, fibra beneficiada (limpa, cortada e separada). Os caminhos que segue a fibra vegetal da piaçava da Bahia, da etapa de manejo da palmeira, extração, até o consumidor final são variados, conforme é ilustrado na Figura 57. A cadeia produtiva inicia nas áreas de extração, podendo ser encontrada na Mata Atlântica, de forma dispersa ou em grandes agregados, também são cultivadas em grandes áreas (50 a 100 hectares) nos sistemas de monocultivos, ou em pequenos cultivos, localmente denominados de 'matas de piaçava', com áreas que variam entre 1 e 15 hectares, esse último modelo consiste em um 'enriquecimento dos roçados', onde famílias quilombolas e agroextrativistas plantam piaçavas e outras culturas como seringueira (Hevea brasiliense), cupuaçu (Theobroma grandiflorum) e cacau (Theobroma cacao). 


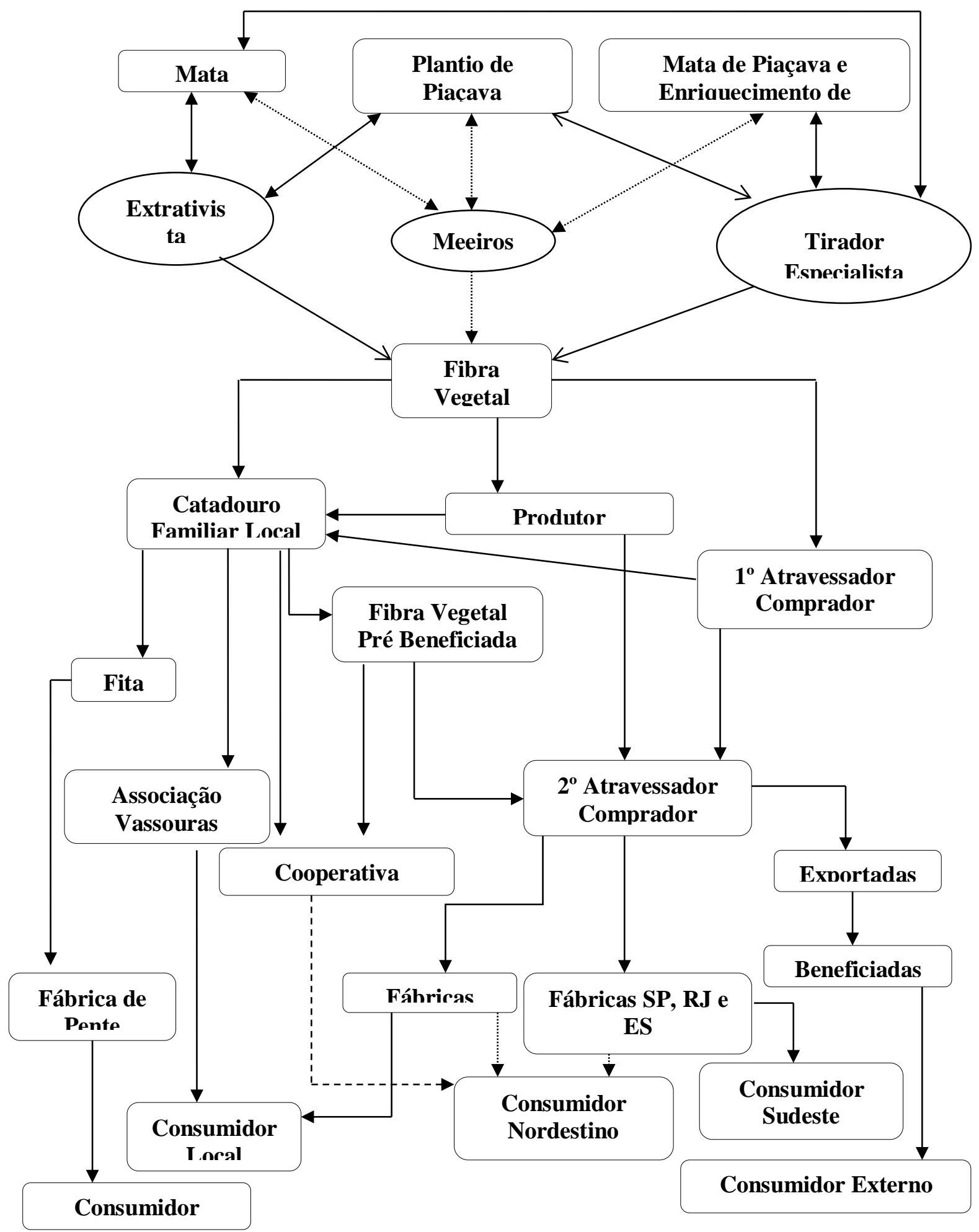

Figura 57: Fluxograma dos caminhos da fibra vegetal da piaçava da Bahia. Estados de São Paulo (SP), Rio de Janeiro (RJ) e Espírito Santo (ES).

As fibras são extraídas por 'tiradores' esses podem ser: extrativistas tradicionais; 'meeiros' e extrativistas especialistas. A fibra bruta é comercializada com o $1^{\circ}$ atravessador ou pré-beneficiada localmente em 'catadouros' familiares. As fibras pré- 
beneficiadas são comercializadas, com um $2^{\circ}$ atravessador, ou beneficiadas até o produto final, na forma de vassouras de piaçava, pelas fábricas, associações e cooperativas.

A Tabela 45 apresenta as etapas de produção da fibra vegetal da piaçava, detalhando os locais onde as atividades produtivas ocorrem, os extrativistas responsáveis por cada atividade e os respectivos valores e preços praticados pelo mercado local, na remuneração pelos serviços extrativistas e valores dos produtos não madeireiros gerados.

Tabela 45: Valores praticados na Bahia (2014), pagos aos extrativistas e preço de comercialização dos produtos gerados.

\begin{tabular}{|c|c|c|c|c|}
\hline \multicolumn{5}{|c|}{ MANEJO DA PAÇAVA - FIBRA BRUTA } \\
\hline Local & Mata & Plantio & \multicolumn{2}{|c|}{ Enriquecimento de roçados } \\
\hline Responsáveis & $\begin{array}{l}\text { Extrativista } \\
\text { Tradicional }\end{array}$ & Meeiros & $\begin{array}{l}\text { Extrativista } \\
\text { Especialista }\end{array}$ & Amarrador \\
\hline Valores pagos $\mathrm{R} \$ / 15 \mathrm{~kg}$ & 11,00 & 12,00 & 30,00 & 1,25 \\
\hline Produto & \multicolumn{4}{|c|}{ Fibra Vegetal Bruta } \\
\hline $\begin{array}{l}\text { Valor comercializado } \\
\mathrm{R} \$ / 15 \mathrm{~kg}\end{array}$ & \multicolumn{4}{|c|}{18,00 a 23,00 (média 20,50/15kg e 1,37/kg) } \\
\hline \multicolumn{5}{|c|}{ PRÉ-BENEFICIAMENTO - FIBRA VEGETAL LIMPA } \\
\hline Local & \multicolumn{4}{|c|}{ 'Catadouros' familiares } \\
\hline Responsáveis & \multicolumn{4}{|c|}{ Mulheres quilombolas e agroextrativistas } \\
\hline Valores pagos & \multicolumn{4}{|c|}{$\mathrm{R} \$ 8,00 / 15 \mathrm{~kg}$ e $\mathrm{R} \$ 0,53 / \mathrm{kg}$} \\
\hline Produto & \multicolumn{2}{|c|}{ Fibra vegetal limpa } & \multicolumn{2}{|c|}{ Fita } \\
\hline $\begin{array}{c}\text { Valor comercializado } \\
\mathrm{R} \$ / 15 \mathrm{~kg}\end{array}$ & \multicolumn{2}{|c|}{$\begin{array}{c}28,00 \text { a } 34,00 \\
\text { (média } 31,00 / 15 \mathrm{~kg} \mathrm{e} 2,1 / \mathrm{kg} \text { ) }\end{array}$} & \multicolumn{2}{|c|}{$\begin{array}{c}17,00 \text { a } 20,00 \\
\text { (média } 18,50 / 15 \mathrm{~kg} \mathrm{e} 1,23 / \mathrm{kg} \text { ) }\end{array}$} \\
\hline \multicolumn{5}{|c|}{ BENEFICIAMENTO: LIMPEZA, CORTE E SELEÇÃO DA FIBRA } \\
\hline Local & \multicolumn{2}{|c|}{$\begin{array}{c}\text { Fabricas RJ, SP, ES } \\
\text { e BA }\end{array}$} & \multicolumn{2}{|c|}{$\begin{array}{c}\text { Associações, cooperativas e } \\
\text { núcleos familiares. }\end{array}$} \\
\hline Responsáveis & \multicolumn{2}{|c|}{ Operários } & \multicolumn{2}{|c|}{$\begin{array}{c}\text { Quilombolas extrativistas e } \\
\text { agroextrativistas. }\end{array}$} \\
\hline Valores pagos $\mathrm{R} \$ / 15 \mathrm{~kg}$ & \multicolumn{2}{|c|}{ Assalariados } & \multicolumn{2}{|c|}{9,00 a 30,00 (média 19,5 ) } \\
\hline Produto & \multicolumn{4}{|c|}{ Fibra vegetal limpa e cortada } \\
\hline $\begin{array}{l}\text { Valores comercializados } \\
\mathrm{R} \$ / 15 \mathrm{~kg}\end{array}$ & \multicolumn{4}{|c|}{$\begin{array}{l}70,00 \text { a } 105,00 \\
\text { ia } 87,50 / 15 \mathrm{~kg} \text { e } 5,23 / \mathrm{kg} \text { ) }\end{array}$} \\
\hline \multicolumn{5}{|c|}{ CONFECÇÃO DA VASSOURA DE PIAÇAVA } \\
\hline Local & \multicolumn{2}{|c|}{ Fabricas RJ, SP, ES e BA } & \multicolumn{2}{|c|}{ Associações, cooperativas } \\
\hline Responsáveis & \multicolumn{2}{|c|}{ Operários } & \multicolumn{2}{|c|}{ Cooperados e quilombolas } \\
\hline $\begin{array}{l}\text { Valores pagos } \\
\mathrm{R} \$ / \text { vassoura }\end{array}$ & \multicolumn{2}{|c|}{ Assalariados } & \multicolumn{2}{|c|}{0,66 por vassoura de cepo } \\
\hline Produto & \multicolumn{4}{|c|}{ Vassoura de cepo tradicional } \\
\hline Valores comercializados & \multicolumn{2}{|c|}{$\begin{array}{l}\text { R\$ 6,00/vassoura } \\
\text { US\$ 2,55/vassoura }\end{array}$} & \multicolumn{2}{|c|}{$\begin{array}{c}\mathrm{R} \$ 3,17 / \text { vassoura } \\
\mathrm{US} \$ 1,35 / \text { vassoura }\end{array}$} \\
\hline
\end{tabular}

As margens brutas de ganho dos extrativistas, considerando somente a etapa de manejo, onde o extrativista extrai a fibra, amarra os feixes de fibra e comercializa com $1^{\circ}$ atravessador pelo valor final de $\mathrm{R} \$ 20,00$ (US\$ 8,51) cada $15 \mathrm{~kg}$ de fibra bruta, são apresentadas na Tabela 46. 
Tabela 46: Margem Bruta Ganho Extrativista com a fibra bruta (2014).

\begin{tabular}{|c|c|c|}
\hline Ator da cadeia produtiva & Valor pago em 15 kg fibra bruta & $\begin{array}{c}\text { Margem Bruta de Ganho } \\
\%\end{array}$ \\
\hline 'Tirador' & $\mathrm{R} \$ 11,00$ (US\$ 4,68) & 55 \\
\hline Amarrador & $\mathrm{R} \$ 1,25$ (US\$ 0,53) & 6,25 \\
\hline $1^{\circ}$ atravessador & $\mathrm{R} \$ 20,00$ (US\$ 8,51) & 38,75 \\
\hline
\end{tabular}

As margens brutas de ganho dos extrativistas quando ele domina as etapas de manejo, pré-beneficiamento e beneficiamento (corte e seleção da fibra limpa), são apresentados na Tabela 47. O calculo das margens brutas tem como base o valor final de venda da fibra cortada que é de $\mathrm{R} \$ 105,00$ (cento e cinco reais) por $15 \mathrm{~kg}$ de fibra cortada.

Tabela 47: Margem Bruta de Ganho Extrativista com fibra beneficiada (2014).

\begin{tabular}{|c|c|c|}
\hline Ator da cadeia produtiva & Valor pago em 15 kg fibra bruta & Margem Bruta de Ganho \% \\
\hline 'Tirador' & $\mathrm{R} \$ 11,00(\mathrm{US} \$ 4,68)$ & 10,4 \\
\hline Amarrador & $\mathrm{R} \$ 1,25(\mathrm{US} \$ 0,53)$ & 1,19 \\
\hline Catadeira & $\mathrm{R} \$ 8,00(\mathrm{US} \$ 3,40)$ & 7,62 \\
\hline Cortador & $\mathrm{R} \$ 30,00(\mathrm{US} \$ 12,77)$ & 28,57 \\
\hline $2^{\circ}$ atravessador & $\mathrm{R} \$ 105,00(\mathrm{US} \$ 44,68)$ & 52 \\
\hline
\end{tabular}

O atravessador recebe $\mathrm{R} \$ 105,00 / 15 \mathrm{~kg}$ (US\$ 44,68/15kg) da fibra limpa e cortada, destinadas as empresas de vassouras. As margens brutas de ganhos de cada ator da acadeia produtiva da fibra bruta vegetal: 10,47\% 'tirador'; 7,62\% 'catadeira'; $28,57 \%$ cortador; e $52 \%$ atravessador.

Conforme exposto acima a atividade produtiva onde a mulher se insere, a etapa da 'cata' da fibra bruta, fundamental dentro do processo produtivo, apresenta uma baixa remuneração das 'catadeiras', principalmente porque se baseia no volume de fibra limpa gerado, sendo desconsiderado o volume de 'fitas' gerados $(17,1 \%)$, esse retorno financeiro é do dono da área de extração ou dono das fibras vegetais brutas. Ou seja, os subprodutos gerados não são contabilizados para a remunaração das 'catadeiras', sendo destinados aos extrativistas que praticam a extração da fibra vegetal. Portanto, a participação feminina dentro da cadeia produtiva da piaçava, corrobora com a situação da mulher negra brasileira, onde essas recebem os menores salários e ocupam posições de menos prestígios.

As extrativistas, quilombolas ou agricultoras familiares, que possuem matas com piaçava ou plantios puros, passam a serem donas da produção ou área de extração e, consequentemente donas dos subprodutos gerados da 'cata' como as 'fitas' para cobertura de quiosques. $\mathrm{O}$ atravessador e o cortador da fibravegetal, obtiveram as melhores margens de ganhos brutos, neste caso o prduto final é a fibra cortada ou beneficiada. 
O custo de produção apresentado pela COOPRAP em agosto de 2013 considera um rendimento do processo em 37,33\% a partir da fibra bruta da piaçava, ainda segundo os administradores da COOPRAP uma palmeira produz uma arroba de fibra, por ano, o 'piaçaveiro' ganhava R\$10,00 (US\$ 4,26) por arroba de fibra bruta extraída e essa fibra é comercializada por $\mathrm{R} \$ 23,00$ (US\$ 9,79) no mercado local, estadual e regional. A piaçava limpa passa para R \$33,00 (US\$ 14,04) por arroba, após o pré-beneficiamento da fibra, e a fibra tratada $\mathrm{R} \$ 75,90$ (US\$ 32,30) por arroba de fibras beneficiadas. O custo de produção de uma única vassoura de cepo tradicional, deste empreendimento foi de $\mathrm{R} \$ 4,38$ (US\$ 1,86) e o preço de venda no atacado desta vassoura de piaçava é de R $\$ 4,52$ (US\$ 1,92). Em 2014 o sistema produtivo deste empreendimento funcionou com dificuldades, apesar do apoio financeiro da Fundação Odebrecht e, em 2015 a situação se intesificou e a COOPRAP fechou as portas.

O custo de produção da COOPAFBASUL foi apresentado em novembro de 2013, esta estimado em R $\$ 2,71$ (US\$ 1,15) por vassoura de cepo de madeira de 18 furos. Com esse modelo de produção descentralizada, a cooperativa é composta por aproximadamente 300 famílias diretamente envolvidas com o extrativismo da piaçava, sendo 200 agricultores familiares e 100 quilombolas. Essa cooperativa acessou a subvenção da piaçava em 2010, 2011, 2012 e 2013, quando, junto com AQBGI e agricultores familiares construíram os três galpões de produção descentralizada. A capacidade produtiva da COOPAFABASUL é de 1.200 vassouras de piaçava por mês, produzidas no Galpão da comunidade de Chico de Dora, Galpão do Quilombo Brejo Grande e 'Catadouro' do povoado de Caeira, todos localizados na zona rural do município de Ituberá. Devido a dificuldades de escoamento da produção, inserção do produto no mercado consumidor e adequações para o cumprimento das exigências legais exigidas pela PGPM-Bio, através da CONAB, os agroextrativistas deixaram de acessar a subvenção da fibra vegetal bruta da piaçava.

Em 2010 a cooperativa comprou fibra bruta de 110 agroextrativistas; em 2011 passou a adquirir de 400 agroextrativistas; em 2012 passou para 600 agroextrativistas. No ano seguinte (2013), somente 30 agroextrativistas comercializaram fibras com a cooperativa e solicitaram a subvenção, porém o dinheiro liberado pela CONAB retornou devido a problemas de prestação de contas. Neste sentido os diretores e gestores da cooperativa vêm afirmando que necessitam de assistência técnica, para acessar corretamente a subvenção da fibra bruta da piaçava. Antes da PGPM-Bio apoiar a cadeia produtiva da piaçava, essas associações e cooperativas da região de Ituberá e Nilo Peçanha, 
não praticavam a compra e venda dos PFNMs oriundos da fibra vegetal da piaçava ${ }^{34}$, somente trabalhavam para os produtores fazendo a extração e limpeza da fibra vegetal bruta, ganhando por produção.

\subsection{3 - Renda Mensal Extrativista}

A renda das famílias quilombolas da região de Ituberá e Nilo Peçanha está fortemente relacionada ao extrativismo da piaçava da Bahia. Os dois principais quilombos existentes no município de Nilo Peçanha, o Quilombo Boitaraca e o Quilombo Jatimane são áreas de ocorrência natural da piaçava, e as comunidades garatem a complementação da renda familiar com base no extrativismo da fibra vegetal da piaçava e da pesca tradicional, juntamente com auxílios governamentais e aposentadorias.

Comercializam a fibra vegetal da piaçva de diversas formas: no pé (produção estimada ainda na planta), bruta (mondongos transportados das áreas), limpa (prébeneficiada) e cortada (fibras para a produção de vassouras diversas), além do artesanato (com fibras e biojóias). No Quilombo Jatimane existe estrutura para produção de biojóias do fruto da piaçava, além do ecoturismo que também acrescenta ganhos financeiros, e utiliza a mão de obra jovem da comunidade quilombola.

Em Ituberá o Quilombo Lagoa Santa, Quilombo Brejo Grande, Quilombo Ingazeira e Quilombo São João de Santa Barbara diversificam os ganhos mensais, entre o extrativismo da fibra vegetal da piaçava (fibra no pé, bruta, limpa, cortada, vassouras e artesanatos), confecção de biojóias com o fruto da piaçava e, a comercialização de outros produtos cultivados na áreas, como: cravo, látex, cacau e cupuaçu, também são beneficiados por auxílios e aponsetadorias, via governo federal. As famílias de agricultores seguem a mesma organização econômica regional, baseada no agroextrativismo vegetal diversificado e complementando os recursos advindos de programas de transferência de renda e benefícios governamentais. Observou-se também um elevado número de ‘catadouros' familiares, tanto na zona rural, como na área urbana do município de Ituberá, na sede municipal encontra-se ainda diversos galpões para armazenamento da piaçava, além de porto fluvial para escoamento da produção em pequenas embarcações.

Os extrativistas de Canavieiras, conhecidos como 'meeiros', tem sua renda baseada essencialmente na extração e limpeza das fibras vegetais. Esta tipologia de extrativista muitas vezes não posssui residência fixa, morando sazonalmente em cada propriedade,

${ }^{34}$ PFNMs oriundos da fibra vegetal bruta: fibras limpas; 'fitas'; fibras cortadas (tipo exportação); fibras finomédias; fibras grosso-médias e vassouras de piaçava da Bahia. 
acompanhado de suas famílias nucleares ou ainda extensas, ou ainda formado por grupos de homens que possuem residência na região. Permanencem de dois a quatro meses em uma propriedade, onde realizam a extração da fibra bruta da piaçava o pré-beneficiamento das mesmas em campo. Depois do acertro realizado com o proprietário seguem para uma nova propriedade e assim continuamente. Outros 'tiradores' possuem residencias fixas na cidade de Canavieiras e se ausentam durante uma empreitada em campo. Em Canavieiras também podemos encontrar galpões direcionados para o pré-beneficiamento, beneficiamento e confecção de vassouras.

A renda mensal extrativista foi calculada pelos coeficientes técnicos da produtividade por pessoa e por dia, rendimentos em fibras vegetais em cada etapa do processo produtivo, média dos valores de compra, venda e a partir da remuneração de cada ator presente na cadeia produtiva, praticados no mercado local e no ano de 2014. Esses coeficientes técnicos são importantes para organização e gestão da atividade, além de ser imprescindíveis nos cálculos de custo de produção e estimativa de ganhos mensais dos extrativistas. Os rendimentos em fibras aproveitáveis e comercializáveis em cada etapa da cadeia produtiva, apresentados nos itens anteriores, também são necessários para mensurar a quantidade de resíduos formados, definição do custo de produção real e consequentemente apontar caminhos, prevendo a inovação tecnológica e manutenção da viabilidade econômica dos empreendimentos.

Os coeficientes técnicos aqui apresentados foram mensurados nos ensaios de rendimento realizados nesta pesquisa, somente na etapa de manejo, optou-se por considerar a produtividade média informada pelos extratores e demais agroextrativistas participantes da pesquisa. A produtividade média da cata e corte das fibras vegetais, além da confecção de vassoura de cepo foram calculados com bases nas médias de tempo, mensuradas nos experimentos realizados e validados junto aos agroextrativistas e operadores. Deste modo os coeficientes técnicos, relacionado ao manejo e processamento da fibra vegetal, apresentados neste trabalho de pesquisa estão sistematizados na Tabela 48.

Tabela 48: Coeficientes técnicos do processamento dos PFNMs oriundos da fibra vegetal bruta da piaçava da Bahia.

\begin{tabular}{|c|c|c|c|c|}
\hline Etapa & Produtividade/dia/pessoa & $\begin{array}{c}\text { Aproveitamento } \\
\text { em fibras \% }\end{array}$ & $\begin{array}{c}\text { Resíduos } \\
\text { gerados \% }\end{array}$ & $\begin{array}{c}\text { Índice de } \\
\text { aproveitamento }\end{array}$ \\
\hline Extração & 15 a $45 \mathrm{~kg}$ ou $37,5 \mathrm{~kg}$ & 100 & 0 & 1 \\
\hline Cata & $81 \mathrm{~kg}$ fibra bruta & 65,6 & 17,3 & 0,66 \\
\hline Corte & 37 kg fibra limpa & 73,2 & 26,8 & 0,73 \\
\hline Confecção & 36 vassouras & 74 & 15,3 & 0,74 \\
\hline \multicolumn{2}{|c|}{ Total Geral Processamento } & 35,6 & 41,8 & 0,36 \\
\hline
\end{tabular}


Os ganhos brutos mensais de um extrativista de piaçava, que se dedica a extração da fibra bruta, ao longo de um mês, trabalhando oito horas por dia, e com uma produtividade média de $37,5 \mathrm{~kg}$ de fibra bruta extraída dia (Tabela 47) é de aproximadamente R $\$ 600,00$ (US\$ 255,32) por mês. Conforme apresentado na Tabela 39 o valor médio pago ao 'tirador' é de R\$12,00 (US\$ 5,11) por arroba e, após um mês de trabalho, o extrativista tem a capacidade de extrair no minimo 50 arrobas.

As mulheres 'catadeiras' normalmente se dedicam quatro hora por dia à atividade de separação da fibra e 'fita' vegetal e, portanto, os calculos da produtividade por pessoa considerou essa forma tradicional de trabalhar. Neste caso, a produtividade por dia por pessoa é de $81 \mathrm{~kg}$ de fibra suja, após um mês é possível processar $1.618 \mathrm{~kg}$ de fibras sujas. Considerando o rendimento de 65,6\% nesta etapa, será formado $1.061,04 \mathrm{~kg}$ de fibras limpas. O valor pago para pré-beneficiar as fibras limpas é R \$ 8,00 (US\$ 3,40) por arroba de fibra limpa geradas. Portanto os ganhos brutos desta profissional, ao longo de um mês é de aproximadamente R \$ 566,08 (US\$ 240,89) para separar e limpar $1.618 \mathrm{~kg}$ de fibra bruta.

Os extrativistas e/ou operadores que se dedicarem somente a etapa de beneficiamento da fibra vegetal, ou seja, o corte, limpeza e selação das fibra vegetais (beneficiamento), ao longo de um mês, podem auferir ganhos brutos mensais na ordem de R \$ 868,56 (US\$ 369,60). Para definição dessa valor, considerou-se a produtividade de 37 kg de fibra limpa por dia, por pessoa (Tabela 48), que após os vinte dias trabalhados terá beneficiado $740 \mathrm{~kg}$ de fibra limpa. Neste caso, o operador adquiriu essa massa de fibra vegetal de outro extrativista e, teve que pagar em média R \$2,3 (US\$ 0,98) por kg de fibra limpa, um gasto de $\mathrm{R} \$ 1.677,33$ (US\$ 713,76). Considerando os 73,2\% de rendimento nesta etapa do processamento os $740 \mathrm{~kg}$ de fibras limpas se transformam em 541,68 kg de fibras cortadas. Essas são comercializadas em média por R\$ 4,67 (US\$2,99) por kg de fibras vegetais cortadas, gerando um ganho bruto de R $\$ 2.545,90$ (US\$ 1.083,36) ao operador que beneficia a fibra limpa. Esse valor menos o gasto com a compra das fibras pré-beneficiadas (limpas) resulta num ganho líquido mensal de $\mathrm{R} \$ \mathrm{R} \$ 868,56$ (US\$ 369,60 ) ao operador, caso ele consiga comercializar sua produção (fibra cortada) por um preço justo no mercado. Os ganhos por produção de fibras cortadas são inferiores, uma média de R \$ 19,50 (US\$ 8,30) por arroba de fibra cortada ou R \$ 1,30 (US\$ 0,55) por kg de fibra cortada, neste caso o extrativista pode auferir um ganho liquido mensal de R $\$ 740,20$ (US\$ 314,98) para beneficiar 541,68 kg de fibras cortadas. 
Ressalta-se que na prática alguns 'tiradores' afirmaram receber mais de $\mathrm{R} \$$ 1.000,00 (US\$ 425,53) por mês, exclusivamente com a extração da fibra bruta, tendo em vista o aumeno da produtividade diária, mais de vinte dias trabalhados e, principalmente, uma maior possibilidade de bargalhar os valores à receber por arroba, devido a falta de profissionais nesta etapa da cadeia produtiva. Enquanto os profissionais envolvidos, com o pre-beneficiamento e beneficiamento da fibra vegtal, afirmam reeber um pouco menos do que os valores aqui apresentados, provavelmente devido a grande oferta e pouca demanda pela fibra vegetal da piaçava. A renda média dos agroextrativistas da região de Nilo Peçanha e Ituberá varia em entre R $\$ 300,00$ (US\$ 127,66) a R \$ 600,00 (US\$ 255,32) por mês e por pesssoa nas etapas de pré-beneficiamento e beneficiamento da fibra vegetal

\subsection{4 - Cenário do Aproveitamento da Fibra Vegetal}

Elaborou-se um cenário onde o agroextrativista domina os processos de produção, realiza todas as etapas do processo produtivo, sozinho, ao longo de um mês. Neste cenário considera-se que as unidades produtivas familiares estão equipadas, funcionando e escoando a sua produção.

A média de produtividade diária de um único extrativista é de aproximadamente $37,5 \mathrm{~kg}$ de fibra vegetal bruta, após uma semana de trabalho, ou cinco dias de trabalho, ele terá extraído e transportado até o 'catadouro' familiar, $187,50 \mathrm{~kg}$ (12,5 arrobas) de fibras brutas. Após o pré-beneficiamento ou 'cata' da fibra vegetal bruta, o extrativista terá $121,88 \mathrm{~kg}$ (8,13 arrobas) de fibras limpas e $31,88 \mathrm{~kg}$ de (2,13 arrobas) 'fitas'. Essas podem ser comercializadas no mercado local por R $\$ 31,00$ (US\$ 13,19) a arroba de fibras limpas e $\mathrm{R} \$ 18,50$ (US\$ 7,87) a arroba de 'fitas'.

Esses $121,88 \mathrm{~kg}$ de fibras limpas, após o beneficiamento ou corte/limpeza/seleção das fibras vegetais, é transformado em 88,97 $\mathrm{kg}$ (5,93 arrobas) de fibras cortadas a $37 \mathrm{~cm}$ de comprimento. Neste caso há formação de $32,91 \mathrm{~kg}$ em resíduos de corte da fibra vegetal da piaçava. As fibras cortadas (beneficiadas) são comercializadas localmente por $\mathrm{R} \$ 4,67$ (US\$ 1,99) o quilo de fibras cortadas ou R \$ 70,00 (US\$29,79) a arroba de fibra cortada.

Para confecção das vassouras de cepo de piaçava com 18 furos é necessário mais limpezas e seleções desses 88,97 kg de fibras cortadas, essa massa é decomposta em 65,84 $\mathrm{kg}(4,39$ arrobas) de fibras fino-médias, $9,79 \mathrm{~kg}$ de fibras grosso-médias e 13,35 kg de resíduos. Com essa massa de fibras fino-médias é possível confeccionar 410 vassouras de cepo com 18 furos. Essas vassouras são comercializadas ao consumidor final por R \$ 6,00 
(US\$ 2,55) podendo gerar um ganho bruto de R\$ 2.460,00 (US\$ 1.046,81) por extrativista por mês, somente com as vassouras de piaçava.

O tempo de serviço do extrativista foi estimado em cinco dias para extrair, cinco dias na atividade de pré-beneficiamento deste volume de fibras brutas, três dias para cortar o volume gerado e mais doze dias para confeccionar as 410 vassouras de piaçava. Totalizando no máximo 25 dias para extrair as fibras, processar e produzir as vassouras, a partir das fibras brutas coletadas das palmeiras.

Adotando os valores de transporte interno apresentado pela CONAB, os custos com transporte interno é aproximadamente R \$ 1,31 (US\$ 0,56) por arroba, o que trazendo para essa realidade hipotética, onde o extrativista transporta $187,50 \mathrm{~kg}$ de fibras brutas, da mata até o 'catadouro' familiar, o custo do transporte equivale R\$ 16,38 (US\$ 6,97) para transportar as fibras brutas. Os insumos necessários para produção de vassoura de cepo são cepos de madeira, cabos, grampos, embalagens e rótulos, estimados pela COOPRAP em $\mathrm{R} \$ 1,90$ (US\$ 0,81) por vassouras de cepo de madeira com 18 furos. Totalizando um custo de produção de $\mathrm{R} \$ 795,38$ (US\$ 338,46) para processar e transformar 187,50 kg $(12,5$ arrobas) de fibras brutas em 410 vassouras.

Deste modo, subtraindo os ganhos brutos menos o custo de produção das 410 vassouras, o extrativista poderá auferir uma renda liquida mensal de aproximadamente R\$ 1.664,63 (US\$ 708,35) trabalhando sozinho durante os 25 dias no mês. Observa-se que os ganhos médios, por extrativista, com a fibra vegetal da piaçava ficaria bem superior, aos ganhos de cada ator separadamente, fato que comprova que a verticalização da produção e o domínio do processo produtivo, pelas famílias agroextrativistas, trazem ganhos sociais, ambientais e econômicos.

A verticalização da cadeia produtiva eleva o ganho bruto e líquido do extrativista da piaçava e, diminuem-se os volumes de fibra vegetal processado, por mês e, por pessoa. Em escala local, dentro dos 'catadouros' familiares, os volumes de fibras manejados será menor, elevando a qualidade do trabalho manual, diminuindo os esforços, elevando-se o aproveitamento da matéria-prima extraída e diminuindo-se as perdas ao longo do processamento. Examinando por uma escala mais abrangente, a verticalização da produção dos PFNMs oriundos da fibra vegetal da piaçava, adotada e praticada pelas comunidades tradicionais, provocará uma menor pressão sobre às áreas de Mata Atlântica, onde a espécie cresce naturalmente, bem como diminuirá a demanda para formação de novos plantios. Os custos de produção com transporte e armazenamento são otimizados e, as 
consequências na mudança do modelo de produção, afetará as demais etapas do processo produtivo, inclusive o manejo florestal da piaçava.

\subsection{5 - Aproveitamento do Fruto da Piaçava da Bahia}

O fruto da piaçava é aproveitado na alimentação dos agroextrativistas, com uso in natura, extração doméstica do óleo vegetal, ingredientes de moquecas e a polpa para o mingau de 'satim'. O endocarpo é utilizado para fazer as biojóias e, neste caso, podem-se utilizar cocos velhos. Os frutos (cocos) utilizados para plantio devem ser colhidos na safra (março, abril, maio, junho), aqueles que já caíram no chão, sem injúrias, furos, etc. Durante os levantamentos de campo os extrativistas e produtores afirmaram coletar e vender frutos in natura com valores bem diversos, mas sempre se referindo ao milheiro do fruto. Esses frutos são vendidos à atravessadores que possivelmente vendem os frutos sem polpa para queima como carvão e/ou exportam os frutos para fazer pisos na Turquia, também informaram que estão vendendo para Argentina. A Tabela 49 apresenta os valores do milheiro nas regiões abordadas neste estudo durante o período de safra do coco.

Tabela 49: Preços do milheiro de frutos por região: Nilo Peçanha, Ituberá e Canavieiras.

\begin{tabular}{|c|c|c|c|}
\hline Local & $\begin{array}{c}\text { Valor R\$/Milheiro do } \\
\text { Fruto }\end{array}$ & $\begin{array}{c}\text { Valor US\$/Milheiro } \\
\text { do Fruto }\end{array}$ & Data \\
\hline Nilo Peçanha & 60,00 & 25,53 & Julho, 2012 \\
\hline Ituberá & 45,00 a 50,00 & 19,15 a 21,28 & Fevereiro, 2015 \\
\hline Canavieiras & 70,00 a 150,00 & 29,79 a 63,83 & Fevereiro, 2015 \\
\hline
\end{tabular}

Os frutos secos e velhos que não possuem mais valor para consumo humano e formação de mudas de piaçava podem ser utilizados na confecção de artesanatos de piaçava, as biojóias (Figura 58), pois a parte utilizada é o endocarpo. Atualmente existem três unidades produtivas de confecção de artesanatos localizadas no Quilombo da Lagoa Santa; Quilombo Jatimane e comunidade de São Francisco. Essas unidades produtivas foram implantadas com apoio da CFAF e da COOPRAP no ano de 2013. Essas ações capacitaram jovens e mulheres quilombolas e, resultou no repasse das técnicas e tecnologias que envolvem a confecção das biojóias da piaçava. Porém os gargalos produtivos de gestão, promoção dos produtos e comercialização persistem e, estas instituições não conseguiram influir neste aspecto. No ano de 2015 a COOPRAP encerrou suas ações na região, após passarem por um período de dificuldades como relatado anteriormente. 


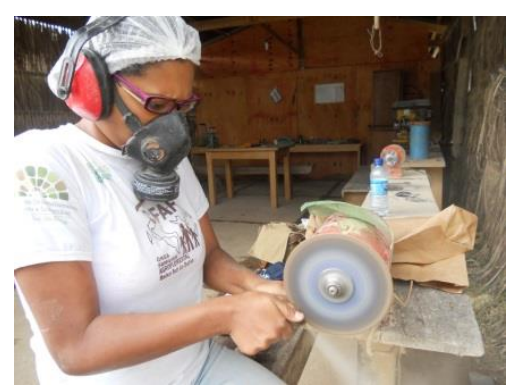

(a)

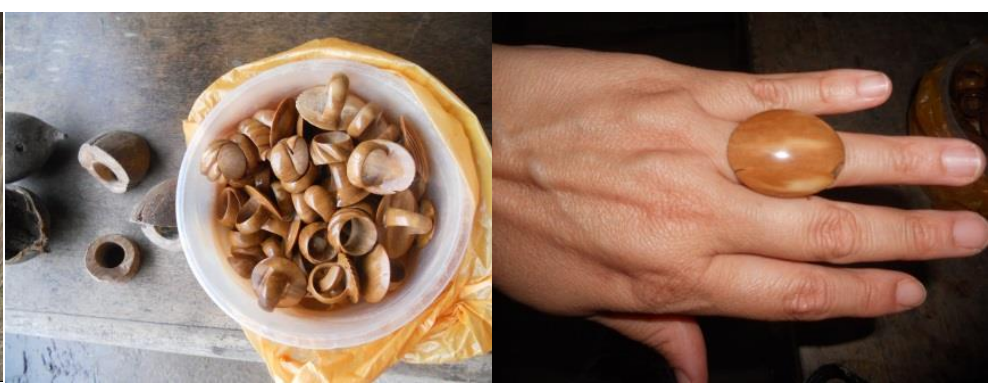

(b)

(c)

Figura 58: (a) Equipamento (esmeril) de lixar o endocarpo do fruto e (b) biojóias do quilombo e (c) anel do endocarpo da piaçava.

As análises do manejo florestal praticado pelos quilombolas do Brejo Grande de Ituberá, nas cinco parcelas de $400 \mathrm{~m}^{2}$ cada, implantadas neste estudo, encontrou-se uma média de 15 plantas na fase de coqueiro, por parcela. Entre essas plantas, em média 5,2 plantas apresentaram frutos (C.V. 80,66\%) e 8,2 plantas apresentaram inflorescências (C.V. 63,59\%) no momento do levantamento em janeiro de 2014. Assim sendo, é possível afirmar que as plantas com frutos representaram, em média, 34,7\% do total de plantas na fase coqueiro e, $54,7 \%$ de plantas na fase coqueiro apresentaram inflorescência ('busa') no mês de janeiro.

Em Canavieiras, as cinco parcelas implantadas, apresentaram 16,2 plantas na fase coqueiro por parcela, sendo encontradas, em média, 3,4 plantas com fruto por parcela, neste caso com elevado coeficiente de variação (C.V. 92,07\%). As plantas com inflorescência, no momento do levantamento (outubro, 2013), representaram em média 9,2 plantas por parcela (C.V. 67,62\%). De acordo com esses valores, encontrou-se 20,99\% de plantas na fase coqueiro e 56,79\% de plantas com inflorescência aparente no mês de outubro. Destaca-se que algumas plantas com fruto também apresentaram inflorescências ('busas') fechadas.

Considerando que as características dos frutos apropriados para o aproveitamento da polpa do 'satim' são diferentes dos frutos adequados para extração do óleo vegetal, por isso, realizou-se dois experimentos, um para cada parte aproveitada. Ambos os experimentos foram considerados nas análises do aproveitamento do endocarpo e rendimento em sementes viáveis. Os resultados encontrados são apresentados nos itens a seguir. 


\subsubsection{1 - Aproveitamento do 'Satim'}

Nas áreas com piaçava, sejam áreas nativas ou plantios implantados, é possível encontrar frutos com características distintas: tamanho dos frutos, porcentagem de polpa, tamanho, quantidade e qualidade de sementes presentes em cada fruto. Entre os frutos coletados para o experimento relacionado ao aproveitamento do 'satim' $90 \%$ de frutos apresentaram polpa de 'satim' e 10\% dos frutos foram descartados, pois não apresentaram polpa. Considerando também os frutos coletados para aproveitamento do 'satim' 43,33\% dos frutos apresentaram sementes no interior do endocarpo (Figura 59).

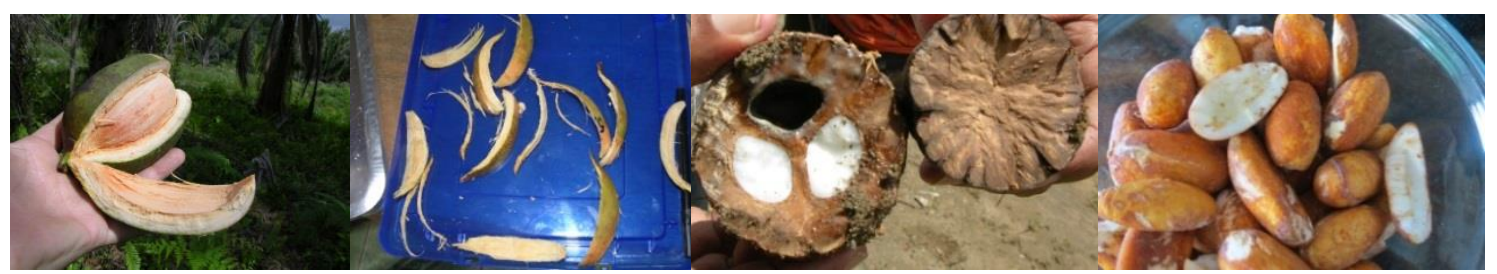

(a)

(b)

(c)

(d)

Figura 59: Fruto da piaçava com epicarpo (a), mesocarpo (b), endocarpo (c) e sementes do fruto da piaçava (d).

O mingau de 'satim' é uma comida quilombola tradicional, consumido nas festas de São João, entre os quilombolas dos municipios Ituberá e Nilo Peçanha, esse mingau é feito com a polpa do fruto ou mesocarpo do fruto da piaçava. $O$ fruto é colhido maduro, recentemente despregado do cacho e, após a sua queda no chão (Figura 60). O extrativista seleciona e coleta os frutos íntegros e viáveis para o aproveitamento da polpa, transporta esses frutos em sacos de polipropileno, a pé, até sua residência. Os frutos são lavados e descascados, ou seja, retira-se o epicarpo de cada um e em seguida retira-se a polpa com uma faca ou ralador manual.

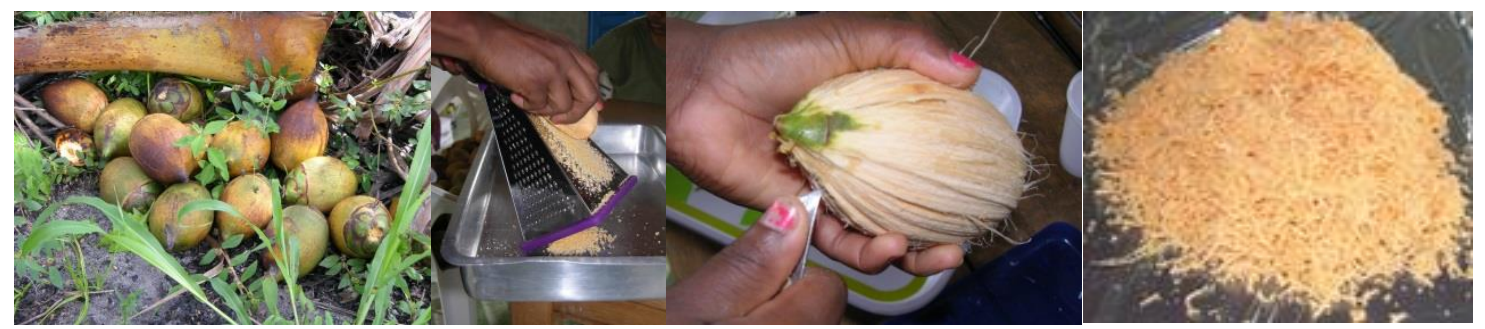

(a)

(b)

(c)

(d)

Figura 60: (a) Frutos maduros, (b) descascados, (c) ralados e (d) polpa do 'satim'.

Essa polpa fica de molho em água por 2 a 3 horas, é coada com pano de prato de algodão. A água coada fica descasando na bacia por mais 24 horas até a goma assentar 
(decante) no fundo da bacia. O sumo restante do coamento, ou seja, as fibras da polpa do fruto (torta) são descartadas, ficando somente o que as comunidades denominam de goma (fecula). A goma (Figura 61) é retirada da bacia e levada ao fogo com leite de coco bem ralo, açúcar e água, para cozimento. A mistura é mexida até formar um mingau de consistência firme, que é depositado em uma panela para esfriar e criar uma consistência ainda mais firme, após esfriamento total. Depois de frio está pronto para o consumo.

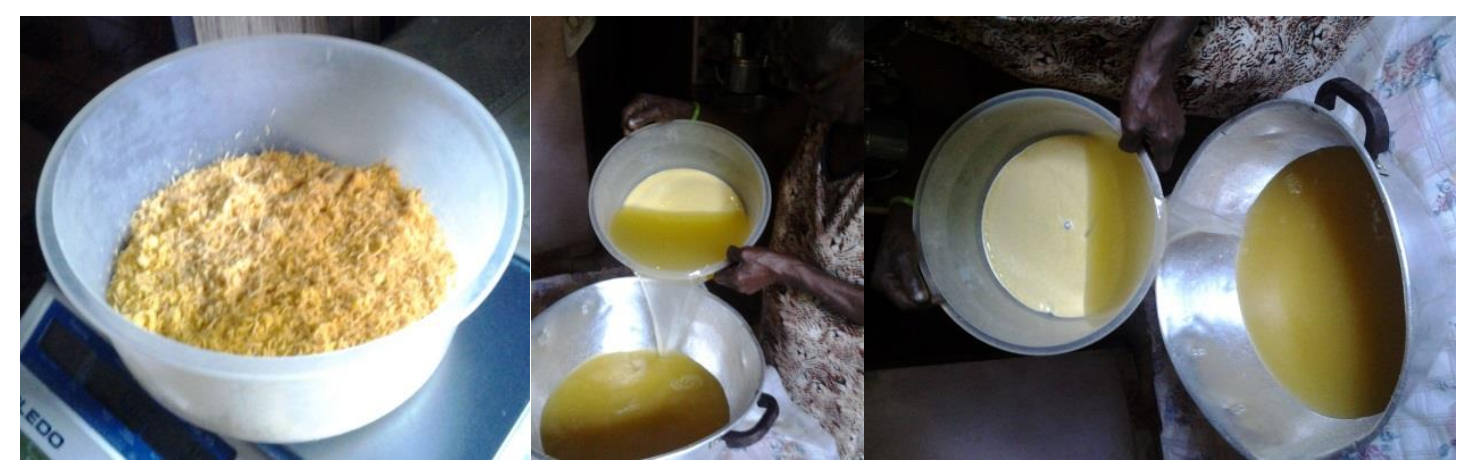

Figura 61: Aproveitamento da polpa do 'satim' para fazer o mingau tradicional.

Outra maneira de conseguir o 'satim' da polpa do fruto é através da extração da polpa, com auxílio de faca e ralador (Figura 60), e colocação da polpa em uma peneira para secar ao sol. Depois de seca, a polpa é pilada e transformada em farinha de 'satim'. Essa farinha de 'satim' era colocaca em garrafas pet e comercializada nas feiras locais. Para fazer o mingau de 'satim' a farinha é colocada de molho em água, coada e retirada à goma para o mingau, mesmo procedimento utilizado com a polpa úmida. $\mathrm{O}$ procedimento de secagem da polpa tem a finalidade de conservar a polpa por mais tempo. Segundo os extrativistas a farinha de 'satim' já foi comercializada nas feiras de locais, Nilo Peçanha, Ituberá e Cairu, há mais de trinta anos. Antigamente, na época de São João (junho), tinha muito mingau de 'satim', está época coincide com o fim do pico da safra do coco da piaçava. Atualmente é pouco consumida, devido aos novos hábitos alimentares das comunidades dessa região.

Os experimentos realizados com a polpa, recém-tirada do fruto, apontaram para o rendimento em torno de 39,8\% de mesocarpo no fruto, sendo aproximadamente 30,8\% em 'satim'(polpa aproveitada na alimentação quilombol) e $9 \%$ constitui-se de fibras grossas que são descartadas na elaboração do mingau. Portanto aproximadamente $40 \%$ do fruto correspondem ao mesocarpo; $16 \%$ correspondem ao epicarpo ou casca do fruto; $39 \%$ equivalem a massa do endocarpo (biojóias) e em média 2,15\% de cada fruto representam as sementes. Os coeficientes de variação estão expressos na Tabela 50. 
Tabela 50: Massa de epicarpo, mesocarpo, endocarpo e de sementes por fruto.

\begin{tabular}{|c|c|c|c|c|c|c|}
\hline & \multirow{2}{*}{$\begin{array}{c}\text { EPICARP } \\
0\end{array}$} & \multicolumn{2}{|c|}{ MESOCARPO } & \multirow{2}{*}{$\begin{array}{c}\text { ENDOCARP } \\
0\end{array}$} & \multirow[t]{2}{*}{ SEMENTES } & \multirow{2}{*}{$\underset{35}{\text { ERRO }}$} \\
\hline & & FIBRAS & SATIM & & & \\
\hline $\begin{array}{l}\text { Massa/fruto } \\
(\mathrm{kg})\end{array}$ & 0,064 & 0,04 & 0,122 & 0,16 & 0,008 & \\
\hline Massa (\%) & 16,63 & 9,67 & $\mathbf{3 0 , 8}$ & 39,4 & 2,15 & 1,3 \\
\hline C.V. (\%) & 21,87 & 16,9 & 11,57 & 8,7 & 36,95 & \\
\hline
\end{tabular}

A massa do endocarpo apresentou a menor variação entre as diferentes partes do fruto amostras, com $8,7 \%$ de coeficiente de variação, menor do que a variação encontrada na amostra de epicarpo dos frutos em torno de $21 \%$. A quantidade de massa da polpa de 'satim' também variou pouco dentro da amostra, pois a coleta dos frutos visou à presença da polpa comestível, no ponto certo e, a coleta foi feita em plantio domesticado, onde o produtor adota as técnicas de manejo para uniformizar a produção. Variação bem diferente para a média de massa de sementes existente em cada fruto, entre 0,005 a 0,02 kg, com C.V em $36,95 \%$, neste caso a semente representou $2,15 \%$ das partes dos frutos coletados. Neste experimento realizado, em campo, $1,3 \%$ corresponde às massas que não foram mensuradas, ou seja, o erro do experimento adotado.

\subsubsection{2 - Rendimento em Óleo Vegetal}

Entre os frutos coletados e processados com a finalidade de extração do óleo vegetal, a semente representa $6 \%$ da massa dos frutos. Entre os 14 frutos mensurados o coeficiente de variação em relação a essa média foi entorno de $38 \%$, demonstrando a heterogeneidade da amostra. Neste experimento os frutos foram beneficiados para aproveitamento das sementes e pelo estado de maturação dos frutos não foi possível separar epicarpo do mesocarpo, pois no fruto muito maduro a polpa vai secando e as fibras restantes ficam aderidas a casca (epicarpo) do fruto mais maduro. No caso dos frutos verdes e 'de vez' a polpa não está no ponto. Portanto neste experimento não foi mensurada a massa de polpa, individualmente.

O epicarpo e mesocarpo, juntos, representaram em média $48 \%$ dos frutos. O endocarpo com sementes correspondem a $36 \%$ do fruto, somando um total de $90 \%$ de aproveitamento dos frutos, restando $10 \%$ de erro ou resíduo não mensurado durante o experimento.

\footnotetext{
${ }^{35} \mathrm{O}$ erro foi calculado considerando que $100 \%$ dos frutos de cada repetição deveriam ter sido mensurados, porém $1,3 \%$ da massa inicial foram perdidas ao longo do experimento de campo.
} 
As sementes representaram 6\% do fruto, valor bem diferente do experimento com a polpa de 'satim', onde as sementes representaram $2 \%$ do fruto. Essa diferença está relacionada aos critérios de coleta dos frutos para extração de óleo e os critérios dos frutos para aproveitamento da 'satim'. Ambas as coletas foram orientadas pelo saber quilombola e a seleção dos frutos diretamente relacionada à parte aproveitada.

A média do rendimento em óleo vegetal das sementes úmidas de piaçava ficou em torno de $37,22 \%$ para sementes maduras e $29,65 \%$ para sementes 'de vez'. A média do rendimento em óleo das sementes secas em estufa a $60^{\circ} \mathrm{C}$, durante $24 \mathrm{hs}$, foi de $53,02 \%$ para as sementes maduras e $50,33 \%$ para as sementes 'de vez'. As sementes 'de vez' apresentaram um menor porcentual de óleo vegetal do que as sementes maduras. Portanto quanto mais maduras forem as sementes, maior a massa de óleo vegetal presente, confirmando informações levantadas em campo, ou seja, o saber quilombola, antes da realização do experimento. A Figura 62 ilustra as duas amostras avaliadas, sementes 'de vez' estão inteiras e sementes maduras foram picadas no momento da extração manual.

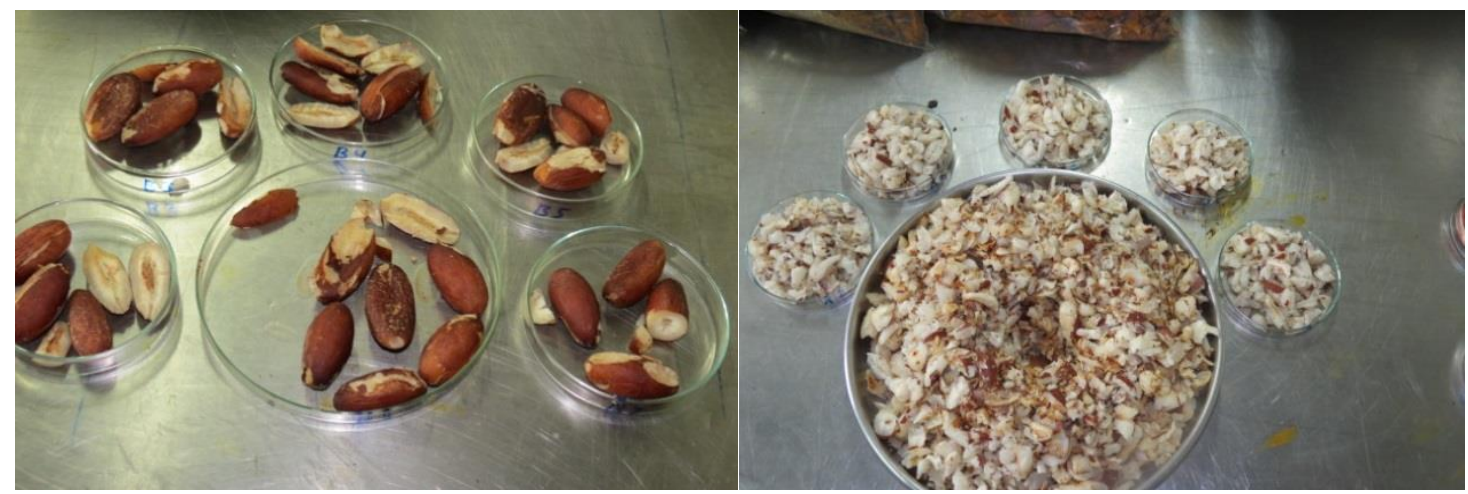

(a)

(b)

Figura 62: (a) Sementes 'de vez' inteiras e (b) sementes maduras picadas. Pós-secagem, antes da extração do óleo vegetal.

O óleo vegetal apresentou um aroma agradável, suave e leve. Na Figura 63 é possível notar as diferentes tonalidades do óleo vegetal extraído das sementes 'de vez' (A) e amostras das sementes maduras (B). 


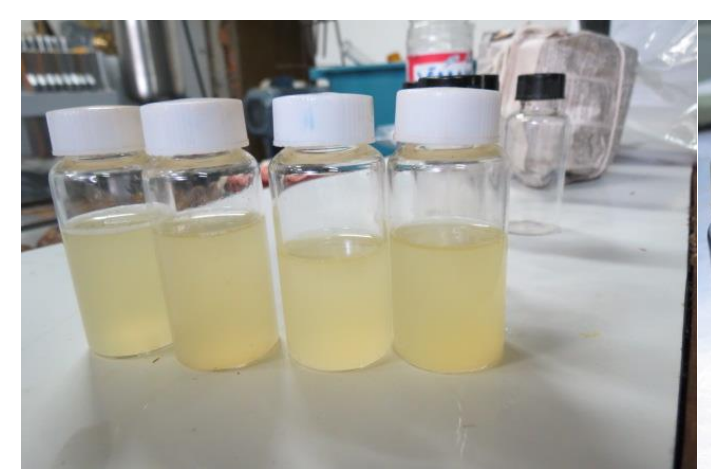

(a)

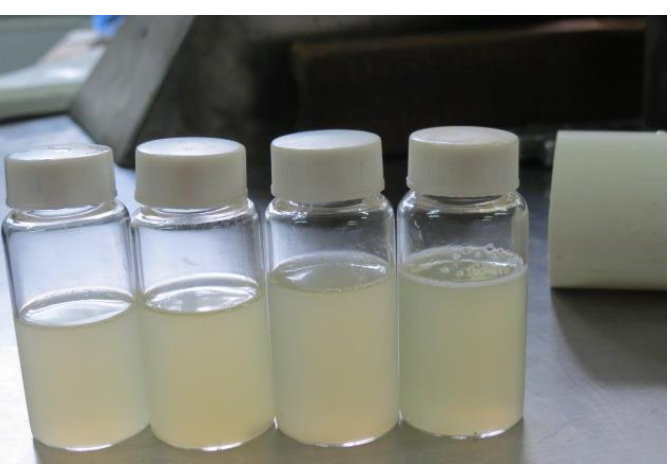

(b)

Figura 63: Óleo vegetal da piaçava: (a) são amostras das sementes 'de vez' e (b) são amostras com óleo das sementes maduras.

A amostra (a), sementes 'de vez' apresentou uma coloração mais amarelada quando comparada a amostra (b), sementes maduras. As sementes 'de vez' são utilizadas na dieta alimentar dos quilombolas e extrativistas da piaçava, são consumidas in natura e apresentam um menor teor de óleo vegetal. As sementes maduras, oriundas de frutos coletados no chão, são procuradas para fazer pratos tradicionais, como moqueca de peixe, ou mesmo extração doméstica do óleo vegetal da piaçava da Bahia.

Diante do exposto, é possível afirmar que os frutos adequados para o aproveitamento do 'satim', recentemente caídos no chão, também são adequados para a extração do óleo. Considerando também que no caso do aproveitamento do óleo vegetal o fruto pode estar sem o epicarpo e o mesocarpo, ou seja, pode estar num estágio mais avançado de maturação.

Existe inidcativos que o óleo vegetal da piaçava esteja sendo extraído e comercializado na cidade de Ilhéus, porém a informação não foi checada. O Dr. Antonio Sturaro, médico pediatra, está requerendo a patente do óleo vegetal do fruto da piaçava, produto rico em óleo laurico, junto ao Instituto Nacional de Propriedade Industrial (INPI), segundo reportagem da revista Conexão Bahia (SEBRAE, 2013), anexada na íntegra (Anexo IV).

\subsection{6 - Aproveitamento da Folha da Piaçava da Bahia}

A piaçava acaule (Attalea funifera) que ocorre no norte da Bahia, também conhecida como piaçava mirim, é aproveitada pela comunidade de Massarandupió, entre outras vizinhas, antes mesmo da colonização do Brasil. Os índios Tupinambá conheciam a planta e dela aproveitavam os frutos, folhas e possivelmente as poucas fibras presentes na 
base da palmeira. Essa fibra da piaçava mirim era denominada pelos Tupinambá de 'cajibá'.

A palmeira não forma o estipe como a piaçava da Bahia, e os grandes pecíolos, também denominadas de 'talas' ou 'tandú', dão estabilidade a palmeira. Atualmente a polpa e as sementes do fruto ainda são consumidas (in natura) pelas extrativistas, durante suas andanças pela restingas e matas da região. $O$ fruto é pequeno e também possui o epicarpo, mesocarpo, endocarpo e sementes (Figura 64).

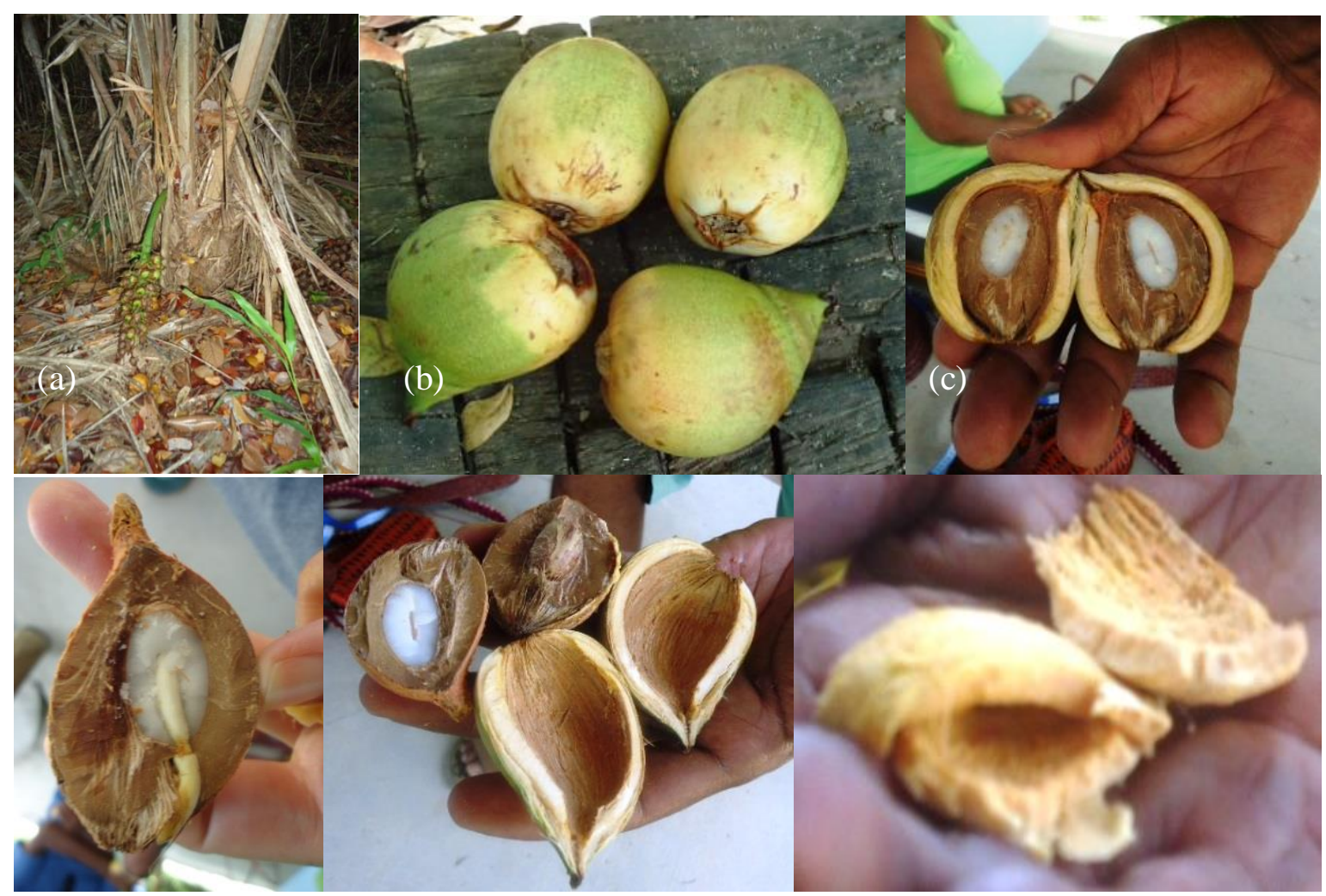

(d)

(e)

(f)

Figura 64: (a) Cacho de fruto da piaçava mirim, (b) frutos fechado, (c) um fruto aberto, (d) início da germinação das sementes, (e) separação do endocarpo e (f) mesocarpo e polpa.

Segundo as extrativistas, Sra. Joana Dias Pereira (Dona Jarinha) e a Sra. Cleonice Oliveira Santos, a polpa do fruto (Figura 64) ou “(...) a lapa do coco” é utilizada para fazer o mingau. As extrativistas também afirmaram que a época do ano que se encontra mais frutos da piaçava mirim é de março a maio. $\mathrm{O}$ fruto é coletado, retira-se o epicarpo, rala o mesocarpo e a polpa resultante é colocada em água limpa. Essa mesma matéria prima é passada nove vezes na água, no mesmo dia, com objetivo de retirar o amargo da polpa. Com essa goma resultante da polpa, faz-se a mistura com leite de coco e o mingau é finalizado. 
As palmeiras são encontradas no sub-bosque das áreas com Mata Atlântica (Figura 65), tem um pequeno porte (acaule) e apresenta uma população aleatória de palmeiras. Em áreas abertas de capoeira as plantas formam uma população agregada. $\mathrm{O}$ aproveitamento da folha do 'olho' da piaçava mirim inicia com a extração da folha da palmeira. As mulheres extrativistas vão em grupo para a mata e/ou restinga, procuram a palmeira que apresente folha nova e parcialmente fechada. Quando encontam a planta com essas caracteristicas, seguram essa folha nova e realizam a extração. O corte não deve afetar a folha do 'olho', folha ainda mais nova, em desenvolvimento, que está no centro da piaçava mirim.

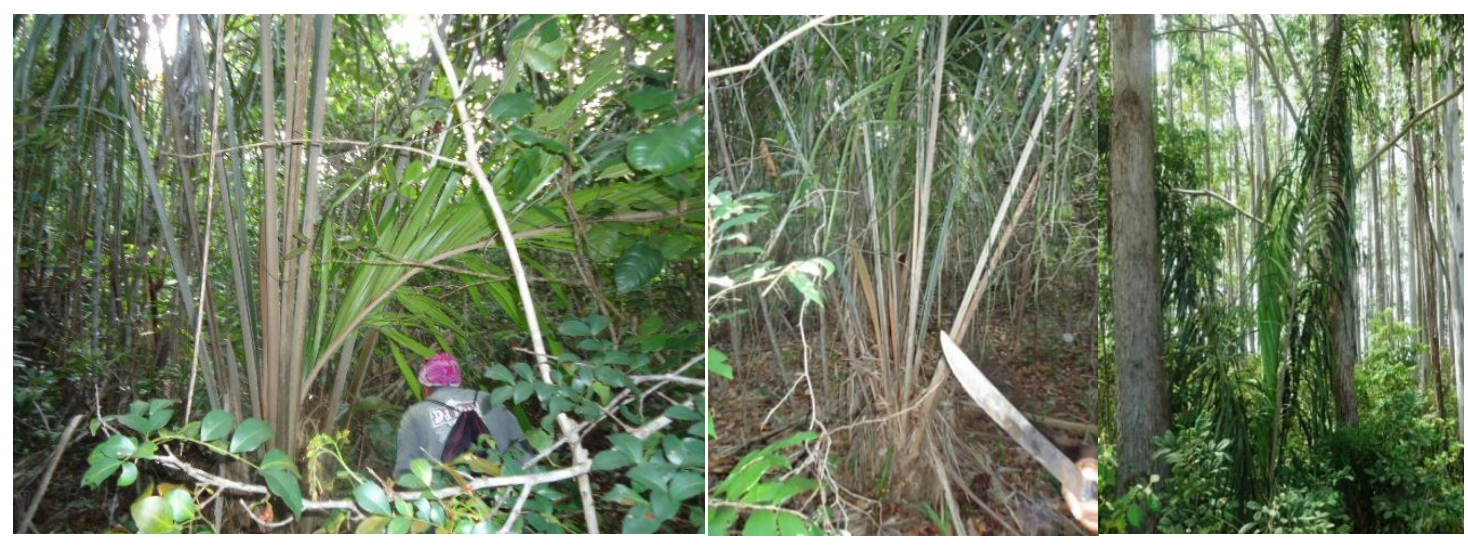

Figura 65: Piaçavas mirins no sub-bosque da mata e plantio de eucalipto.

Com o uso do facão a extrativista corta a folha parcialmente fechada, na direção contrária à pequena folha do 'olho' que está completamente fechada. As folhas maduras possuem todos os folíolos abertos, as folhas novas, iniciam seu desenvolvimento com os folíolos fechados. A folha parcialmente fechada é a selecionada para extração das palhas (folíolos), são os folíolos ainda fechados que são aproveitados, por serem mais trabalháveis, no entendimento das extrativistas, àquelas "palhas moles". Os folíolos fechados estão na base da folha extraída, possuem a coloração amarelada, conforme Figura 66, ao amadurecerem e abrirem passa para coloração verde. Esses folíolos novos e fechados são retirados manualmente da raque da folha, um por um, atividade conhecida como a "despenca das palhas". 


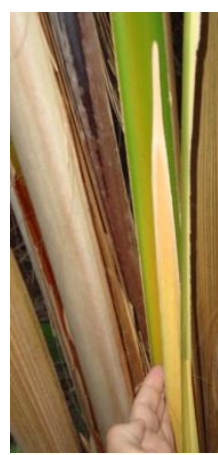

(a)

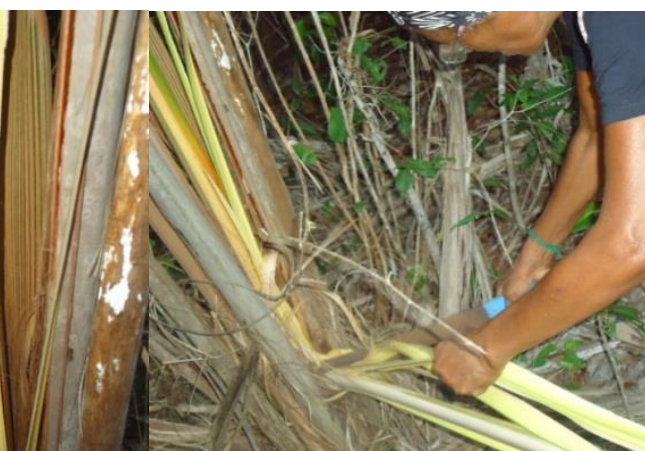

(b)

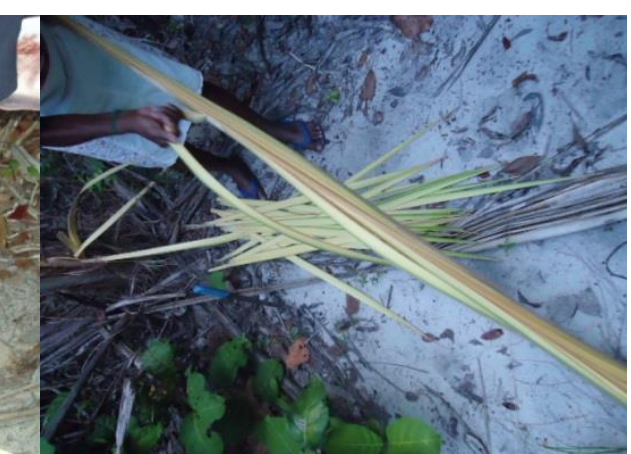

(c)

Figura 66: (a) Folha do 'olho', (b) folha parcialmente fechada extraída e (c) corte manual dos folíolos "despenca das palhas" após a extração, ainda em campo.

A extrativista junta os folíolos em um feixe ('molho') e os transporta a pé para o beneficiamento na sede da Associação das Artesãs de Massarandupió (ADAM). Esse material é organizado em rodelas dentro da panela, fixado com duas madeiras em formato de cruz, coloca-se água para o inicio do cozimento e, fervem-se os folíolos novos por aproximadamente vinte minutos.

O tingimento dos folíolos pode ser natural ou artificial com anilina. As extrativistas da comunidade de Massaradupió utilizam o cipó rego, encontrado na mata junto com a piaçava mirim, e as sementes de urucum (Bixa orellana). Neste caso as extrativistas fazem primeiro a tintura e, depois que os folíolos foram pré-cozidos, eles são colocados dentro da tintura e fervidos novamente. O cipó de rego apresenta uma coloração roxa escura e o urucum a cor laranjada. A Figura 67 ilustra os folíolos sendo pré-cozidos, em seguida sendo pintados com a tintura do cipó de rego na panela e, após aproximadamente dez minutos, o feixe pintado de roxo escuro. A última figura ilustra os folíolos tingidos de urucum escorrendo o excesso de água e fixando a tinta natural.

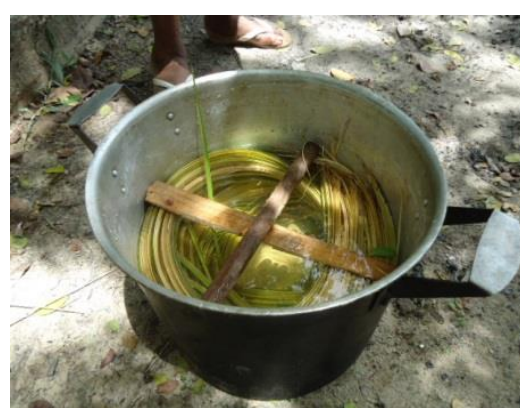

(a)

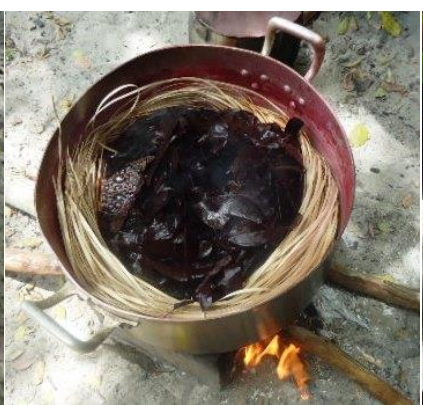

(b)

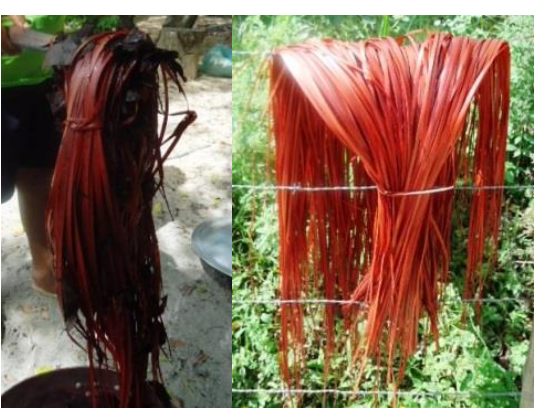

(c) (d)

Figura 67: (a) Cozimento dos folíolos novos, (b) e (c) tingimento natural com cipó de rego, (d) folíolos tingidos com urucum. 
Após o tingimento natural ou artificial, os folíolos são colocados para retirar o excesso de água e em seguida são abertos manualmente, um por um, formando um circulo localmente conhecidos como a "roda da palha" ou "caimbo" (Figura 68). Os folíolos devem ser secos ao avesso, ou seja, a parte interna do folíolo deve ficar para fora do circulo formado.

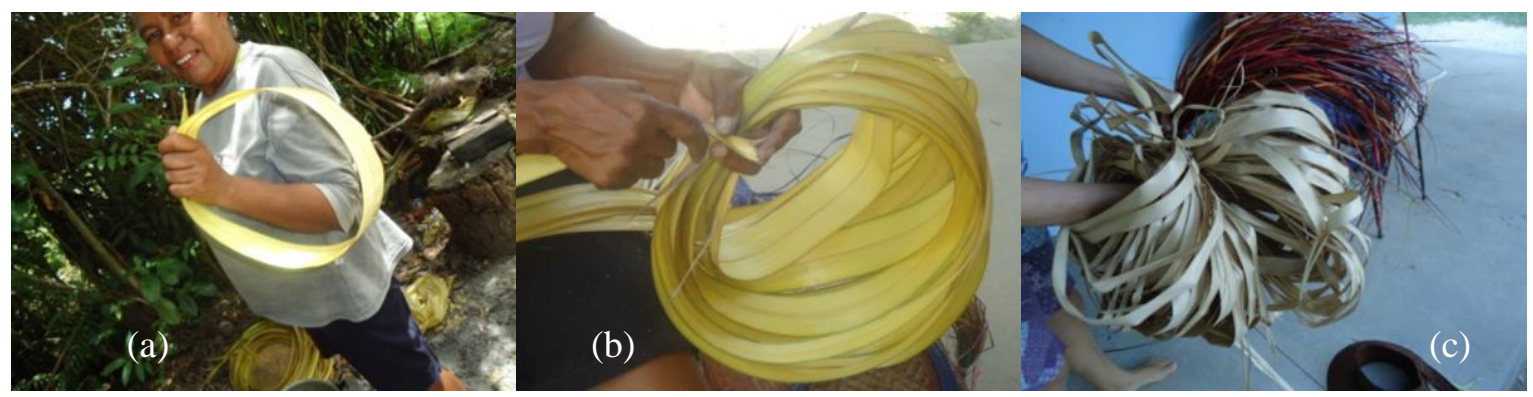

Figura 68: (a) Abertura dos folíolos pós-cozimento na coloração natural; (b) feixe formado após o cozimento; e (c) feixes ou "rodas da palha" da piaçava mirim secas.

Após a secagem dos folíolos abertos em circulo, esses são cortados, etapa conhecida como "riscar a palha" em pequenas tiras ou linhas que são trançadas para formar uma 'braça' com 1,70 metros em média de comprimento (Figura 69c). Essas 'braças' são costuradas com linha de licuri (Syagrus coronata) na confecção de esteiras, chapéus, bolsas, entre outras peças. As extrativistas da região próxima a Massarandupió comercializam o 'molho de palha bruta' por $\mathrm{R} \$ 40,00$ a $\mathrm{R} \$ 50,00$ entre os extrativistas e $\mathrm{R} \$ 1,50$ por braça (comprimento de 1,70 metros) de palha já trançada e utilizada na confecção dos artesanatos.

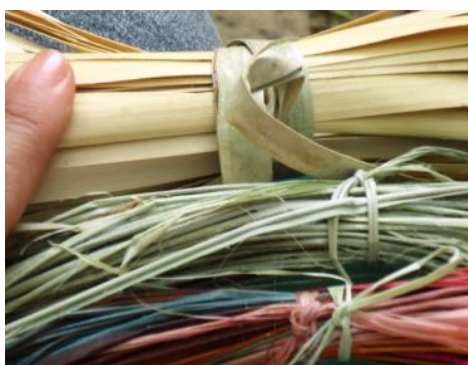

(a)

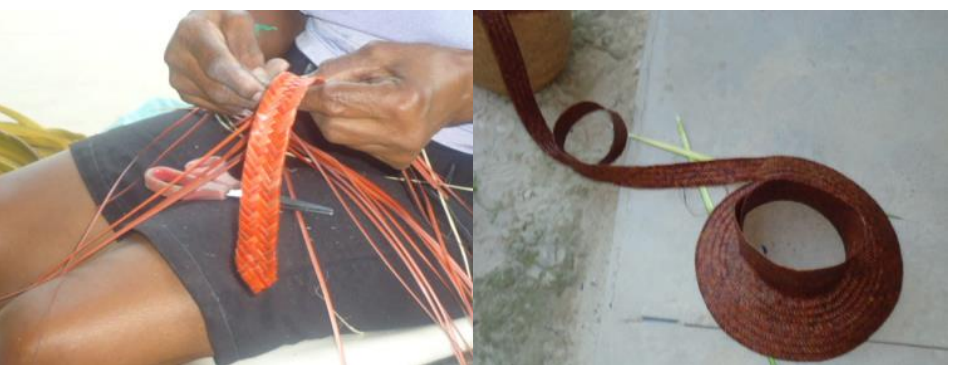

(c)

Figura 69: (a) são folíolos brutos, linha de licuri (verde) e tiras de piaçava; (b) trançado com as tiras de piaçava; (c) 'braça' das tiras trançadas sendo utilizadas para confeccionar um chapéu da palha da piaçava.

A pratica do extrativismo da folha nova da piaçava mirim não foi observada no sul da Bahia, tanto porque não foi identificda a presença dessa variedade, piaçava mirim, 
quanto pelo domínio das técnicas de extração, beneficiamento, trançados e confecção das peças de bolsas, tapetes, cestos, carteiras, chapéus, entre outros objetos (Figura 70).

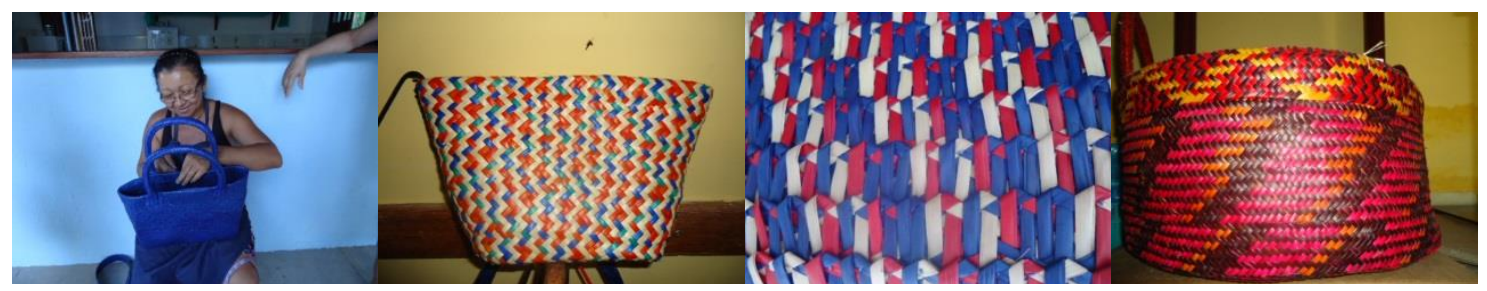

Figura 70: Bolsas, trançados e cestos com a folha da piaçava mirim confeccionados pelas extrativistas de Massarandupió.

Os insumos externos necessários para confecção desses artesanatos são a agulha e a anilina (tingimento artificial), pois a linha de licuri é retirada da palmeira de mesmo nome que também é de ocorrência natural na região. A renda da familiar na região é composta por aposentadorias, pela pesca, ou trabalhos relacionados ao turismo na região (barracas das praias e/ou nos hotéis da região). As artesãs da comunidade de Massarandupió, extrativistas da folha da piaçava mirim, recebem entre $\mathrm{R} \$ 300,00$ a $\mathrm{R} \$ 800,00$ por mês, com a venda das peças confeccionadas com a folha e comercializadas na comunidade e pontos turísticos como Porto de Sauipe. 


\section{6 - CONCLUSÕES E RECOMENDAÇÕES}

As metodologias empregadas foram satisfatórias para apontar os coeficientes técnicos de rendimento, bem como, apresentar equações para o extrativista estimar a massa de fibras fino-médias, fibras grosso-médias, fitas e resíduos a partir das fibras vegetais brutas extraídas da palmeira Attalea funifera.

As perdas apresentadas no processo produtivo foram na ordem de $17,3 \%$ na etapa de pré-beneficiamento; $26,8 \%$ na etapa de beneficiamento, $15,3 \%$ na etapa de confecção da vassoura. $\mathrm{Na}$ análise integrada das etapas do processo produtivo de confecção das vassouras de piaçava, os resíduos formados foram na ordem de $41,8 \%$.

O rendimento em vassouras de cepo com 18 furos foi resumido na seguinte relação, $1 \mathrm{~kg}$ de fibras fino-média gera 6,22 vassouras de piaçava. Portanto $15 \mathrm{~kg}$ de fibras brutas gera aproximadamente 33,2 vassouras de cepo com 18 furos. As análises de tempo, realizadas nos experimentos de campo, permitiu apontar a produtividade média diária de cada extrativista em cada etapa produtiva, coeficientes utilizados para estimar a renda, aproximada, de cada extrativista.

A renda média estimada de um extrativista da fibra bruta vegetal da piaçava foi de R \$ 600,00 (US\$ 255,32) por mês; a extrativista que transforma a matéria prima bruta em fibra limpa apresentou uma renda média mensal de aproximadamente R $\$$ 566,08 (US\$ 240,89); o extrativista que beneficia a fibra limpa transformando em fibra cortada (tipo exportação) exibiu uma renda de R \$ 868,56 (US\$ 369,60). A renda média mensal do extrativista que domina todas as etapas de produção, ou seja, aquele que realiza todas as etapas do processamento, sua renda líquida passa a ser de aproximadamente $\mathrm{R} \$ 1.664,63$ (US\$ 708,35) com a venda do produto final diretamente ao consumidor.

Comprova-se, portanto, que a verticalização da cadeia produtiva e a inserção no mercado local, regional e nacional dos produtos oriundos dessas comunidades agroextrativistas eleva a renda mensal extrativista. A margem de ganhos dos extrativistas será tanto maior quanto maior for o domínio das etapas produtivas pelas comunidades quilombolas e agroextrativistas

Deve-se considerar que o custo de produção com transporte da fibra bruta da mata até o 'catadouro' para o pré-beneficiamento; transporte do 'catadouro' até o galpão para o beneficiamento e do galpão até as industrias de confecção de vassouras; são elevados e desnecessários com a apropriação das etapas produtivas por parte dos agroextrativistas. 
O aproveitamento integral dos PFNMs oriundos da piaçava da Bahia pode gerar ainda mais ganhos aos agroextrativistas, bem como a elaboração de novos produtos, domínio das etapas do processamento da vassoura por parte dos extrativistas e escoamento da produção em determinados nichos de mercados.

As metodologias adotas para análise dos frutos se mostraram úteis, sugerindo um aumento no esforço amostral, fato que não diminue a importância dos resultados aqui apresentados, também informações inéditas. O fruto da piaçava com popa de 'satim' apresentou uma média de 16,63\% de epicarpo; 9,67\% de polpa (mesocarpo) com fibras e $30,8 \%$ de polpa (mesocarpo) de 'satim'; 39,4\% de endocarpo ósseo; e 2,15\% de sementes neste ensaio. $\mathrm{O}$ endocarpo representou $38 \%$ no ensaio de rendimento para aproveitamento do óleo vegetal e, as sementes representaram $6 \%$ dos frutos beneficiados para extração do óleo vegetal.

O rendimento em óleo vegetal das sementes úmidas foi em média 37,22\% em se tratando das sementes maduras e $29,65 \%$ das sementes 'de vez'. A média de rendimento do óleo vegetal extraídos das sementes secas $\left(60^{\circ} \mathrm{C}\right)$ foi de $53,02 \%$ para as sementes maduras e 50,33\% para as sementes 'de vez'. Portanto as sementes maduras apresentam maior teor de óleo vegetal, exatamente àquelas utilizadas para extração doméstica do óleo vegetal pelas comunidades quilombolas.

Recomenda-se que seja feito o mapeamento detalhado das áreas com a palmeira, definição precisa do território, elucidando se as áreas são unidades especialmente protegidas, assentamentos, posseiros ${ }^{36}$, empreendimentos turísticos, pequenos, médios e grandes produtores da fibra vegetal no sul da Bahia. Também são relevantes estudos para averiguar a viabilidade genética e modificações na população da palmeira. Com essas informações e as geradas pelos estudos anteriores, bem como as contribuições fetais nessa tese, é possível definir políticas públicas para a gestão do território da piaçava.

Estudos com a caracterização das espessuras das fibras limpas, conforme às exigências do mercado; propriedades mecânicas das fibras grossas descartadas na etapa de beneficiamento da fibra vegetal da piaçava; novos vassouras de limpeza urbana que utilizem as fibras grossas descartadas; equipamentos de limpeza urbana adaptados à realidade local brasileiro que utilizem a fibra vegetal da piaçava; e um melhor aproveitamento do fruto (polpa, endocarpo e sementes) e das folhas da Attalea funifera.

${ }^{36}$ A categoria de posseiro é entendida como aquele que adquire (ou ocupa) e faz uso de uma determinada área de terra sem ter título de propriedade expedido, em seu nome, pelo Estado ou pela União (MYSKIW, 2002 apud SILVA, 2013). 


\section{REFERENCIAS BIBLIOGRÁFICAS}

AGOPYAN, V; SAVASTANO Jr, H. 1997. Uso de materiais alternativos a base de fibras vegetais na construção civil: experiência brasileira. In: Seminário Ibero-americano de materiais Fibrorreforçados. p 23-40.

AGRELA, S. P.; THOMAS, N.I.R.; JOSE, N. M.; CARVALHO, R. F. 2009. Phisical Characterization of piassava (Attalea funifera Mart) fibre and lees. In: $11^{\text {th }}$ International Conference on Non-conventional Materials and Technologies. Bath, UK : University of Bath, v. 1.

ALICEWEB, 2015. Sistema de Análise das Informações do Comercio Exterior. Ministério do Desenvolvimento, Indústria e Comercio Exterior. http://aliceweb.mdic.gov.br

AQUINO, R. C. M. P.; D’ALMEIDA, J. R. M.; MONTEIRO, S. N. 2002. Desenvolvimento de compósitos de matriz polimérica e piaçava, como substitulo de produtos de madeira. Vértices, v. 1, p. 42-47.

AQUINO, R. C. M. P. 2003. Desenvolvimento de compósitos de fibras de piaçava da espécie Attalea funifera Mart e matriz de resina poliéster. Tese de Doutorado em Engenharia e Ciências dos Materiais, Universidade Estadual do Norte Fluminense Darcy Ribeiro. Centro de Ciência e Tecnologia. Laboratório de Materiais Avançados. 150p.

AVELAR, F. F. 2008. Utilização de fibra de piaçava (Attalea funifera) na preparação de carvões ativados. Dissertação de mestrado em Agroquímica pela Universidade Federal de Lavras - UFLA, 72p.

BARBIERI, J. C.; ÁLVARES, A. C. T. 2003. Inovações nas organizações empresariais, p. 41-63. In: Organizações inovadoras: estudos e casos brasileiros. Rio de Janeiro: FGV, $164 \mathrm{p}$.

BARRETO, R. O. 2009. Técnicas de Manejoe sustentabilidade da palmeira Attalea funifera Martius - piaçava da Bahia. Candombá - Revista Virtual, Salvador, BA, v. v. 5, n.2, p. p. $80-97$.

BERGAMO, A.; RODRIGUES, L. 2007. Inventário completo da Piaçava - Attalea funifera. Empresa Horizonte XXI. Ponto Central, Santa Cruz Cabrélia, Bahia, 14 p.

BEZERRA, R. T. P. 2014. Utilização de fibras residuais de piaçava (Attalea funifera M.) em mistura com cimento Portland para produção de painéis compósitos. Monografia para obetnção de titulo de Engenheiro Florestal pela Universidade de Brasília - UnB, 48p.

BONDAR, G. 1942. A piassava e outras palmeiras Attaleaineas na Bahia. Intituto Central de Fomento Econômico da Bahia (ICFEB), Salvador, Bol. n. 13, 73p.

BONELli, C. M. C.; ElZUBAIR, A.; SUAREZ, J. C. M.; MANO, E. B. 2005. Complementação térmico, mecânico e morfológico de compósitos de polietileno de alta densidade reciclado com fibras de piaçava. Polímeros: Ciência e Tecnologia, v. 15, p. 256260 . 
BRAZILIAN FIBRES. Piaçava do Brasil. Disponível em: http//www.brasilianfibres.com.br Acesso em 15 de dezembro de 2014.

CAMPANILI, M.; SCHAFFER, W. B. (org), 2010. Mata Atlântica: patrimônio nacional dos brasileiros. Ministério do Meio Ambiente. Secretaria de Biodiversidade e Florestas. Núcleo Mata Atlântica e Pampa; organizadores. - Brasília: MMA, 408 p.

CAMPOS, J. C.; LEITE, H. G. 2013. Mensuração Florestal: perguntas e repostas. Ed. $\mathrm{UFV}, 4^{\circ}$ edição, 605p.

CANDIDO, S. A.; SOULÉ, F. V.; PIRES, M. B. 2008. Desenvolvimento e Implantação de Mini-Fábricas de Produtos Florestais Não Madeireiros em Comunidades Ribeirinhas da Amazônia. Encontro Nacional de Engenharia de Produção, 28, Anais. Rio de Janeiro: ABEPRO.

CANTUÁRIA, S. 2008. Análise Expedita dos Territórios Sintese dos Relatórios de Viagem. Coordenação de Agroextrativismo/SDRS/MMA. Brasília, 74 p. (BRA 99/025 Produto 2 TDR $\mathrm{N}^{\circ}$ 129217).

CHERKASOV, A. 1998. Classification of non-timber resources in the USSR. Acta Bot. Fennica, 136: p.3-5.

CLEMENT, C. R.; LLERAS, P. E.; LEEUWEN, J.; 2005. O potencial das palmeiras tropicais no Brasil: acertos e fracassos das últimas décadas. Agrociencias , 9 (1-2): 67-71.

Corrêa, M.P. 1926. Dicionário das plantas úteis do Brasil e das exóticas cultivadas. Rio de Janeiro, Imprensa Nacional.

COSTA, D. M.; SANTOS, E. M. 1985. A Comercialização da Piaçava através de Sistema Cooperativo do Sul da Bahia. Ilhéus: CEPLAC, Serie Desenvolvimento Regional, n. 16, $22 \mathrm{p}$.

D’ALMEIDA, A.L.F.S.; BARRETO, D.W.; CALADO, V.; D’ALMEIDA, J.R.M. 2006. Efeito de tratamentos superficiais em fibras de piaçava sobre o comportamento dinâmicomecânico de compósitos de matriz poliéster isoftálica. In: Congresso Brasileiro de Engenharia e Ciência dos Materiais, 17, Foz do Iguaçu. Anais... CBCIMat, (1):3582-3593.

D’ALMEIDA, J. R. M.; AQUINO, R. C. M. P.; MONTEIRO, S. N. 2006b. Tensile mechanical properties, morphological aspects and chemical characterization of piassava (Attalea funifera) fibrs. Composites: Part A, v. 37, p.1473-1479.

DINIZ, J. D. A. 2008. Avaliação-construção de projetos de desenvolvimento local a partir da valorização de produtos florestais da Amazônia Brasileira: caso da castanha- do-brasil. Tese de doutorado. Brasília: Centro de Desenvolvimento Sustentável/UnB,

DAGNINO, R.; BRANDÃO, F. C.; NOVAES, H.T. 2004. Sobre o marconceitual da tecnologia social. In: LASSENCE Jr., A. et a. Tecnologia social - Uma estratégia para o desenvolviemnto. Rio de Janeiro: Fundação banco do Brasil. 
EMPERAIRE, L. 2000. A floresta em jogo: O extrativismo na Amazônia Central. Org. Laura Emperaire. São Paulo: Editore UNESP: Imprensa Oficial do Estado. Vários autores. Vários tradutores. Titulo original: Lafôret em jeu. Bibliografia ISBN 85-7139-295-1. 233p.

FORNARI, C. I.; FORNARI JR. C. C. M. Avaliação da força de cisalhamento das fibras longas de piaçava em poliester insaturado. Etudos tecnológicos em Engenharia, 9 (1): p. 27-36.

FILDER, N. C.; SOARES, T. S.; SILVA, G. F. 2008. Produtos Florestais Não Madeireiros: Importância e Manejo Sustentável da Floresta. Revista Ciencias Exatas e Naturais. Vitória, v.10, n² , p.264-278.

FRANKE, I. L. 2005. A aprendizagem tecnológica e organizacional na performance do sistema produtivo e institucional do RECA. Dissertação de Mestrado em Desenvolvimento Sustentável. Centro de Desenvolvimento Sustentável. Universidade de Brasília. Brasília, Distrito Federal, 195p.

FUNDAÇÃO CULTURAL PALMARES. 2014. Lista de comunidades remanescentes de quilombos. Certidões espeditas até 2014. Endereço eletrônico http//www.palmares.gov.br

GALETTI, M; ALEIXO, A. 1998. Effects of palmheart harvesting on avian frugivores in the Atlantic rain forest of Brazil. Journal of Applied Ecology, London v. 35, p. 286-29.

GAMA, A. T.; OLIVEIRA, J. R. V.; MARTINS, E. C. 2009. Cartilha de Apoio ao Plano de Manejo Comunitário da Piaçava na Reserva Pataxó da Jaqueira. Instituto BioAtlântica $\&$ MDA. Porto Seguro.

GLEISER, M. 1997. A Dança do Universo - Dos mitos de criação ao Big Bang. São Paulo: Companhia das Letras.

GUIMARARÃES, C. A. L.; SILVA L. A. M. 2012. Piaçava da Bahia (Attalea funifera Martius): do extrativismo à cultura agrícola. Ilhéus, BA: Editus. 262p.

GUIMARARÃES, C. A. L.; Piaçava da Bahia: Attalea funifera Martius. Disponível em: http//www.agricultura.gov.br Acesso em 27 de novembro 2014.

GTZ. 2007. Manual Value Links - A Metodologia de Promoção da Cadeia de Valor. Brasília.

HOMMA, A. K. O. 1993. Extrativismo vegetal na Amazônia: limites e oportunidades. EMBRAPA - SPI. 202p.

HORI, M. 1970. O Cultivo da Piaçava na Micro Região - Programa 3 - Litoral Sul. CEPLAC/CEPEC, Ilhéus, $6 \mathrm{p}$.

IBGE. 2004. Vocabulário Básico de Recursos Naturais e Meio Ambiente. Instituto Brasileiro de Geografia e Estatística. $2^{\circ}$ ed. Rio de Janeiro. ISBN 85-240-3766-0, 332p. 
IBGE. 2014. Produção da Extração Vegetal e Silvicultura. Instituto Brasileiro de Geografia e Estatistica, Rio de Janeiro, v. 19 a v. 28 , 55 p. Acesso em dezembro de 2013, disponível em: www.ibge.gov.br/home/estatistica/economia/pevs/2013

IQBAL, M. 1993. International trade in non-wood forest products: An overview. Rome, Italy: Food and Agriculture Organization.

ITTO. 1998. The Case for Multipll-use Management os Tropical Hardwood Forests. Harverd University Cambridge. Massachusetts.

JESUS, N. B.; GOMES, L.J. 2012. Conflitos Socioambientais no Extrativismo da Aroeira (Schinus terebebinthifolius Raddi), Baixo São Francisco - Sergipe/Alagoas. Ambiente \& Sociedade, São Paulo v. XV, n. 3, p. 55-73.

JONES, J. R. 1969. Review and comparison of site evalution methods. Rocky Mountain For. Exp. Station: USDA, Forest Service, 27 p.

KAGEYAMA, P. Y. 200. Dispersão de sementes de Euterpe edulis Martius. In: REIS, M. S.; REIS, A. (Ed.). Euterpe edulis Martius - (palmiteiro): biologia, conservação e manejo. Itajaí: Herbário Barbosa Rodrigues, p. 202-224.

LORENZI, H.; NOBLICK, L.; KAHN, F.; FERREIRA, E. 2010. Flora Brasileira Arecaceae (Palmeiras). Nova Odessa, SP, Instituto Plantarum de Estudos da Flora Ltda. $384 \mathrm{p}$.

LORENZI, H.; SOUZA, H. M.; MEDEIROS-COSTA, J. T.; CERQUEIRA, L. C.; FERREIRA, E. 2004. Palmeiras Brasileiras e Exóticas Cultivadas. Nova Odessa, SP, Instituto Plantarum de Estudos da Flora Ltda. P.62-97.

MACHADO, F. S. 2008. Manejo de Produtos Florestais Não Madeireiros. Rio Branco, AC: PESACRE e CIFOR, 105p.

MATOSSO, L. H. C.; PEREIRA, N.; SOUZA, M. L.; AGNELLI, J. A. M. 1996. Utilização de fibras vegetais para reforço de plásticos. Empresa Brasileira de Pesquisas Agropecuária, v. 3, p.1-4.

MEIRA, M. 2000. Os índios do rio xie e a fibra da floresta. In: EMPERAIRE, L. 2000. A floresta em jogo: O extrativismo na Amazônia Central. Org. Laura Emperaire (Org.). São Paulo: Editore UNESP: Imprensa Oficial do Estado. Vários autores. Vários tradutores. Titulo original: Lafôret em jeu, p. 31- 48.

MELO, J. R. V.; SOUZA, J.; NAKAGAW, J.; SILVA, L. A. M.; MORI, E. S. 2000. Perspectiva da produção de sementes de piaçava (Attalea funifera Mart.) em áreas litorâneas do estado da Bahia. In: Congresso e Exposição Internacional sobre Florestas (FOREST 2000), VI, 2000, Porto Seguro. Anais, p. 157-159.

MENSIER, P. H.; NOGUEIRA, J. B.; MACHADO, R. D. 1946. Glossário de Palmeiras Oleaginosas e Ceríferas. Ministério da Agricultura, CNEPA/ SNPA, Instiruto de Óleos, $108 p$. 
MERCADO LIVRE, 2015. Empresa Pozzimaquinas. Endereço eletrônico (pozzimaquinas.com.br) Acesso em 23 de janeiro de 2015.

MIRANDA, C. S.; FIUZAB, R. P.; CARVALHO, R. F.; JOSÉA, N. M. 2014. Efeito dos Tratamentos Superficiais nas Propriedades do Bagaço da Fibra de Piaçava Attalea Funifera Martius. Quim. Nova, Vol. XY, No. 00, p. 1-5.

MMA. 2010. Plano Nacional de Promoção das Cadeias de Produtos da Sociobiobiversidade. Brasília: Ministério do Desenvolvimento Agrário, Ministério do Meio Ambiente, Ministério do Desenvolvimento Social e Combate a Fome.

MONTEIRO, S. N. LOPES, F. P. D. 2006. Ensaios de Impacto em Compositos polimericos reforçados com fibras de curuá. In: $61^{0}$ Congresso Anual da Associação Brasileira de Metalurgia e Materiais - ABM, Rio de Janeiro, RJ, Brasil.

MONTEIRO, S. N. ; AQUINO, R. C. M. P.; LOPES, F. P. D.; D’ALMEIDA, J. R. M. 2006b. Tenacidade ao entalhe por impacto charpy de compósitos de poliéster reforçados com fibras de piaçava. Revista Matéria, v. 11, p. 204-210.

MOREAU, M. S. 1997. Ocorrência, Produtividade e canais de Comercialização da Piaçava (Attalea funifera Mart.) em Ilhéus, Una e Canavieiras - Bahia. Tese (Mestrado em Fitotecnia), Escola de Agronomia, UFBA, Cruz das Almas, 62 p.

MOREAU, M. S.; SILVA, L. A. M. Produtividade da Piaçaveira (Attaleab funifera Mart). Magistra, Cruz das Almas, v. 7, 1999.

MORAES, P. 1911. A Piassabeira: A Extinção dos Piassabaes Naturais e sua Necessária Cultura. Chácaras e Quintais, n. 3, p.15-16.

MOTA, D. M.; SILVA JÚNIOR, J. F.; GOMES, J. B. V. 2003. Lógicas de estratégias social de uma população tradicional de catadores de mangaba no litoral sul sergipano. In: Simpósio Brasileiro sobre a Cultura da Mangaba, Aracaju: Embrapa Tabuleiros Costeiros.

MYSKIU, A. M. 2002. Colonos, posseiros e grileiros: conflitos de terra no oeste paranaense (1961/66). Niterói, dissertação de mestrado em história - Universidade Federal Fluminense (UFF). Disponível www.historia.uff/br/nra/textos/Myskiw.

NASCIMENTO, D. C. O. 2009. Analise das Propriedades de Compósitos de Fibras de Piaçava e Matriz de Resina Epóxi. Tese de doutorado da Universidade Estadual Do Norte Fluminense - UENF, Campos Dos Goytacazes - RJ, 137p.

PÉLLICO-NETTO, S. P.; BRENA, D. A. 1997. Inventário Florestal. Curitiba, Editoriado pelos autores, 316p.

NETO, F. L.; PARDINI, L. C. 2006. Compositos Estruturais: Ciência e Tecnologia. Ed. Sao Paulo: Edgar Blucher.

NOBILICK, L. R. 1991. The indigenous palms of the state of Bahia, Brazil. Tese (doutorado em botânica). University of Illions, Chicago, 523p. 
NOBLICK, L.R. 1986. Palmeiras das caatingas da Bahia e as potencialidades econômicas. Simpósio sobre a Caatinga e sua Exploração Racional, Brasília, DF, EMBRAPA, p.99115.

NOGUEIRA, M. 2005. Quando o Pequeno é Grande: uma análise de projetos comunitários no Cerrado. São Paulo: Annablume, 172 p.

OLIVEIRA, H. B. 2012. Relatório Técnico de Avaliação: APL da Piaçava no Baixo Sul Baiano - BA (N 14), Projeto PNUD BRA/08/012.

PIMENTEL, N. M.; DEL MENEZZI, C. H.; GONÇALEZ, J. 2009. Aproveitamento dos Produtos Florestais Não Madeireiros do Baru (Dipteryx alata Vog,). In: NURIT BENSUSAN, Unindo Sonhos: pesquisas ecossociais no cerrado. Brasília: Instituto Internacional de Educação no Brasi, p. 269-293.

PIMENTEL-GOMES, F. 2009. Curso de Estatistica Experimental. FEALQ (15º edição), $451 \mathrm{p}$.

PETERS, C. M. 1996. Sustainable harvest of non-timber plant resources in Tropical Moist Forest: an ecological primer. Washington DC, United States, Biodiversity Support Program, 45 p.

PETERS, C. M. 1996. Aprovechamiento sostenible de recursos no maderables en el bosque húmedo tropical: un manual. (B. S. Program, Ed.) Washinton: D.C. United States, Programa de Apoyo a la Biodiversidad.

PNUD. 2013. Atlas do Desenvolvimento Humano dos Municípios brasileiros. Endereço eletrônico: http//www.pnud.org.br/IDH

PRASAD, R.; DAS, S.; e SWANDIP, S. 1999. Value Options for Non-timber Forest Products at Primary Colletor's Level. International Forestry Review, v. 1, n.1, p.17-21.

REIS, M. S. et al. 2000. Manejo sustentável e produtividade do palmiteiro (Euterpe edulis Martius Arecaceae). In: REIS, M. S.; REIS, A. (Ed.). Euterpe edulis Martius (palmiteiro): biologia, conservação e manejo. Itajaí: Herbário Barbosa Rodrigues, p. 202224.

REIS, M.S.; CONTE, R.; FANTINI, C.A.; GUERRA,M.P. 2002. O palmiteiro como recurso da Mata Atlântica. In: SIMÕES, L.L.; LINO, C.F.(orgs.). Sustentável Mata Atlântica - a exploração de seus recursos florestais. São Paulo: Editora SENAC São Paulo, p.103-117.

SAVASTANO, JR. H.; PIMENTEL, L.L. 2000. Viabilidade do aproveitamento de reíduos de fibras vegetais para fins de obtenção de material de construção. Revista Brasileira de Engenharia Agrícola e Ambiental, v. 4 p. 103-110.

SATYANARAYANA, K. G.; GUIMARÃES, J. L.; WYPYCH, F. 2007. Studies on lignocellulosic fibrs of Brasil: source, production, morphology, properties and applications. Composites; Parte A, v.38, p.1694-1709. 
SCHUCHARDT U.; BIANCHI M. L.; GONÇALVES, A. R.; CURVELO, A. A. S.; BISCOLLA, F. C.; PERES, L. O. 1995. Piassava fibrs (Attalea funifera). I. Chemical analysis, extraction and reactivity of its lignin. Celluse Chemistry Technology, v. 29, p. 705-712.

SCHUMACHER, F. X.; HALL, F. S. 1933. Logarithmic expression of timber-tree volume. Journal of Agricultural Research, v. 47, n 9, p. 719-734.

SEBRAE, 2013. Benefícios da piaçava. Revista Conexão Bahia, publicação do SEBRAE Bahia $^{\circ}$ 204, p. 15-17. Acesso http://issuu.com/sebraebahia/docs/conexao_204/15

SHANLEY, P.; PIERCE, A.; e LAIRD, S. 2005. Além da Madeira: certificação de produtos florestais não-madeireiros. Bogor, Indonésia: Centro de Pesquisa Florestal Internacional (CIFOR), 153p.

SHANLEY, P.; MEDINA, 2005. Frutíferas e Plantas Úteis na Vida Amazônica. Amazônia, Brasil: Centro de Pesquisa Florestal Internacional (CIFOR), 153p.

SHANLEY P.; GARCIA C. 2005. Palestra: O papel dos produtos florestais não madeireiros e o uso múltiplo das florestas. In: Oficina de Manejo Comunitário e Certificação Florestal na América Latina - Resultados e Propostas. Org: Paulo Amaral, Frank Kramer; Manuel Amaral Neto. IMAZON/GTZ/IEB.

SILVA JÚNIOR, J.F. 2004. A cultura da mangaba, Revista Brasileira de Fruticultura, v.26, n.1, 192p.

SILVA, L. A. M.; VINHA, S. G. 1985. Ocorrência da piaçaveira e vegetação a associada no município de Canavieiras, Bahia. CEPLAC/CEPEC, Ilhéus, BA, Boletim técnico n. 132, 19p.

SILVA, L. A. M.; VINHA, S. V. 1982. A piaçaveira (Attalea funifera Mart.) e vegetação associada no município de Ilhéus, Bahia. CEPLAC/CEPEC, Ilhéus, BA, Boletim Técnico n. $101,12 \mathrm{p}$.

SILVA, L. A. M. 2002. Piaçava - 500 anos de extrativismo. In: SIMÕES, L. L.; LINO, C. F. (org.) Sustentável Mata Atlântica: a Exploração de seus recursos Florestais. São Paulo: SENAC São Paulo, p. 71-84.

SILVA, L. R. M.; GUIMARÃES, C. A. L. 2006. A Piaçava do Litoral da Bahia. In: Semana do Fazendeiro $28^{\circ}$ Uruçuca. Uruçuca: CEPLAC, v. 2, p.334-342.

SILVA, E. R. 2013. Comunidade negra Lagoa Santa: história, memória e luta pelo acesso e permanência na terra (1950-2011). Dissertação de mestrado. Pontífica Universidade Católica de São Paulo - PUC-SP. 2009p.

SIMONI, Jane. A Revitalização do Extrativismo: Práticas de Economia Solidária e Sustentabilidade. in IPEA, Economia Solidária e Políticas Públicas. Boletim Mercado de Trabalho no. 42. Brasília: 2010. 
SFB - Serviço Florestal Brasileiro. 2014. Florestas Comunitárias. Acesso em 24 de maio de 2014.http://www.florestal.gov.br/florestas-comunitarias/sobre-florestas

SOARES, T. S.; SILVA, G. F. 2008. Produtos Florestais Não Madeireiros: Importância e Manejo Sustentável da Floresta. Revista Ciências Exatas e Naturais, Vol.10, n².

SOUZA, T. F. 2012. Avaliação da Resistência de Compósitos de Argamassas Leves de Eva Reforçadas com Fibras de Piaçava. Dissertação apresentada ao Programa de PósGraduação em Ciência, Inovação e Modelagem em Materiais da Universidade Estadual de Santa Cruz, UESC, Bahia. 148p.

SOUZA, A. D.; VICENTE, C. R. 2003. Manejo de productos Medicinales no Maderables: Un Enfoque Forestal. In: Simpósio sobre Plantas Medicinales y Aromáticas - Uma Alternativa de Diversificación em cultivo en las Regiones Andina y Agroindustriales de Colombia, v.2, p.59-69. Medellin, Colômbia.

TERBORGH, J. 1986. Keystone plant resources in tropical forests. In: SOULÉ, M. E. (Ed.). Conservation biology: the science of scarcity and diversity. Sunderland: Sinauer, p. 330-44.

THOMAS, N. I. R. 2010. Compósitos de poliéster reforçados com tecidos de fibras de licuri para construção civil. Dissertação de mestrado - Universidade Federal da Bahia, Salvador.

VINHA, S. G.; SILVA, L. A. M. 1998. A Piaçava da Bahia. Ilhéus: Editus, 48 p.

VOEKS, R. A. A biogeogrphy of the piassava fiber palm (Attalea funifera Mart.) of Bahia, Brasil. University of California, Berkeley, USA, 288 p.

VOEKS, R. A. 1988. Changing Sexual Expression of Brazilian Rain Forest Palm (Attalea funifera Mart.). BIOTROPICA, California, U.S.A., v. 20 (2), p.107-113.

WICKENS, G. E. 1991. Manegement issus for development of non-timber forest products. In: UNASYLVA, v.42 (165), p. 3-4.

YOUNG, R. A. 1997. Utilization of Natural Fibers: Characterization, Modification Applications. USA: Madison.

ZAR, J. H. 2009. Biostatistical Analysis. $5^{\text {th }}$ Edition, 960p.

ZUGAIB, A. C.; COSTA, D. A. M. 1998. Comercialização da piaçava. CEPLAC/DEADE (publicação avulsa), Ilhéus, Bahia, 28p. 


\section{ANEXO I}

\section{DECLARAÇÃO DE ANUÊNCIA \\ ASSOCIAÇÃO QUILOMBOLA DA COMUNIDADE DO BREJO GRANDE ITUBERÁ - BAHIA}

Declaro que a pesquisadora Noara Modesto Pimentel, matrícula: 11-0054598, doutoranda em Ciências Florestais pela Universidade de Brasília - UnB vem desenvolvendo pesquisa sobre o extrativismo da Piaçava (Attalea funifera) na região de Ituberá, Nilo Peçanha e Canavieiras, desde julho de 2012. Contribuiu no desenvolvimento dos equipamentos para produção de vassouras (tecnologia social), junto com a equipe da Cooperativa dos Agricultores Familiares do Baixo Sul COOPAFBASUL.

A pesquisadora tem concordância da Associação Quilombola da Comunidade do Brejo Grande, para a execução, em suas instalações, de seu projeto de pesquisa e extensão. Levantamento de dados junto às famílias quilombolas extrativistas da comunidade de Brejo Grande.

Afirmo disponibilizar ao referido pesquisador toda infra-estrutura necessária e as facilidades pertinentes à consecução do seu projeto, até o seu término (fevereiro/2015).

Para que sejam produzidos todos os efeitos legais, técnicos e administrativos deste compromisso, firmo o presente instrumento.

Ïtullerá/ Pampo do - BA. 11 de dezembro de 2013

Representante Legal da Instituição:

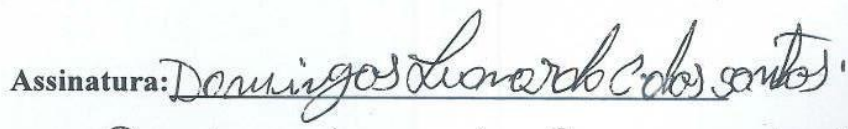

Nome: Domingo Leonardo Conceicás los Sontos

CPF: $246575145-04$

Cargo ou função: Presidente da Ansciazáo Qhilandala da Comunidad

Nomeado conforme: do Brejo grande

Eleto em arsembléia local

na conunidade campo do Anáneio 
Manuel Edson dos Sontos -

conseltho Fixal Homael Edetron to romb

Nelson de Jesus. CNelorron de Jesues
Tesonira

Carlos Alberto lonceucáa dos Sontos for los Alb reto con täo dos 5 Moradon/Sócio

Navia Antonia dos Sontos - María Antomi ar dor Sansto Moradora / Antesá da Pioçara

Balbina Conciergá dos Santos- Ballima bon cuisão deos santo. Moradora/Sócia

196 
ANEXO II

MAPAS COM A OCORRÊNCIA DA PIAÇAVA

Principais municípios produtores de piaçava na Bahia

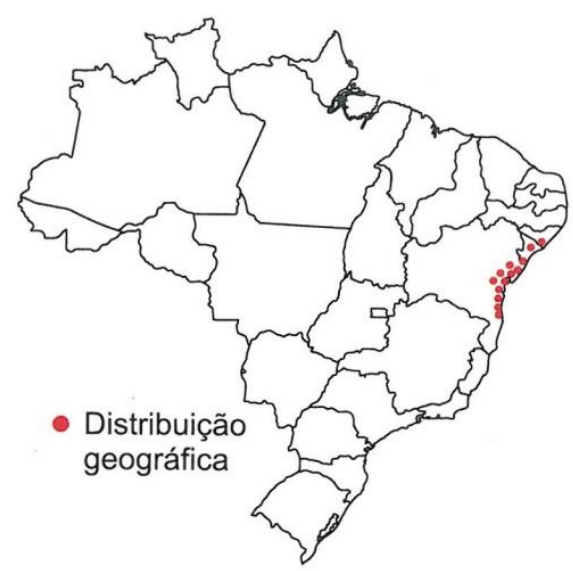

Fonte: Lorenzi, 2010

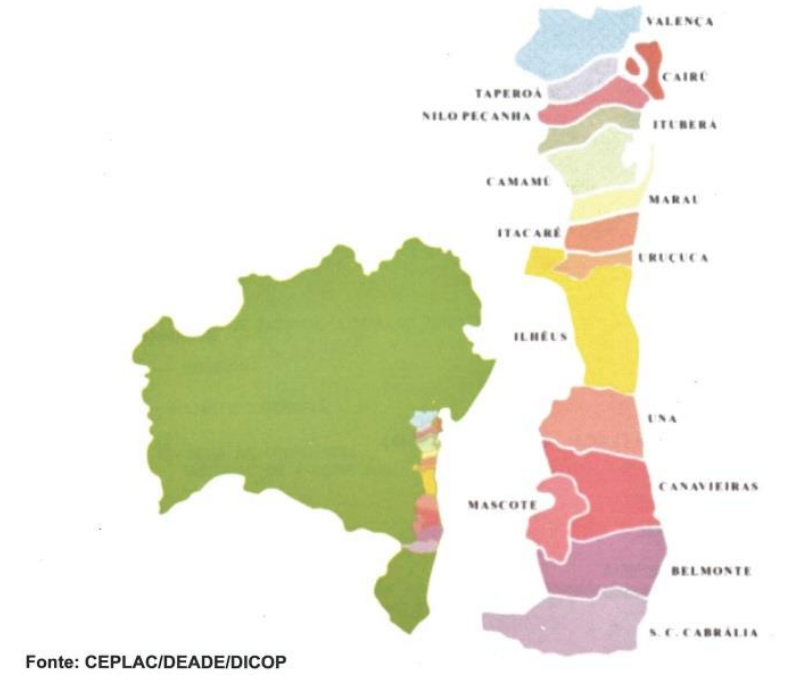

Fonte: Guimaraes; Silva, 2012

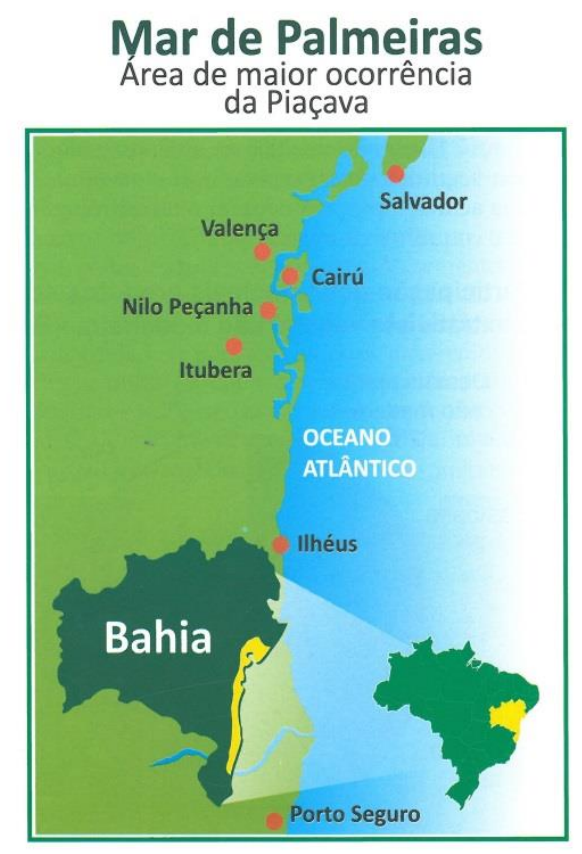

Fonte: CASALI (2004)

Fonte: GLASSMAN (1999) 


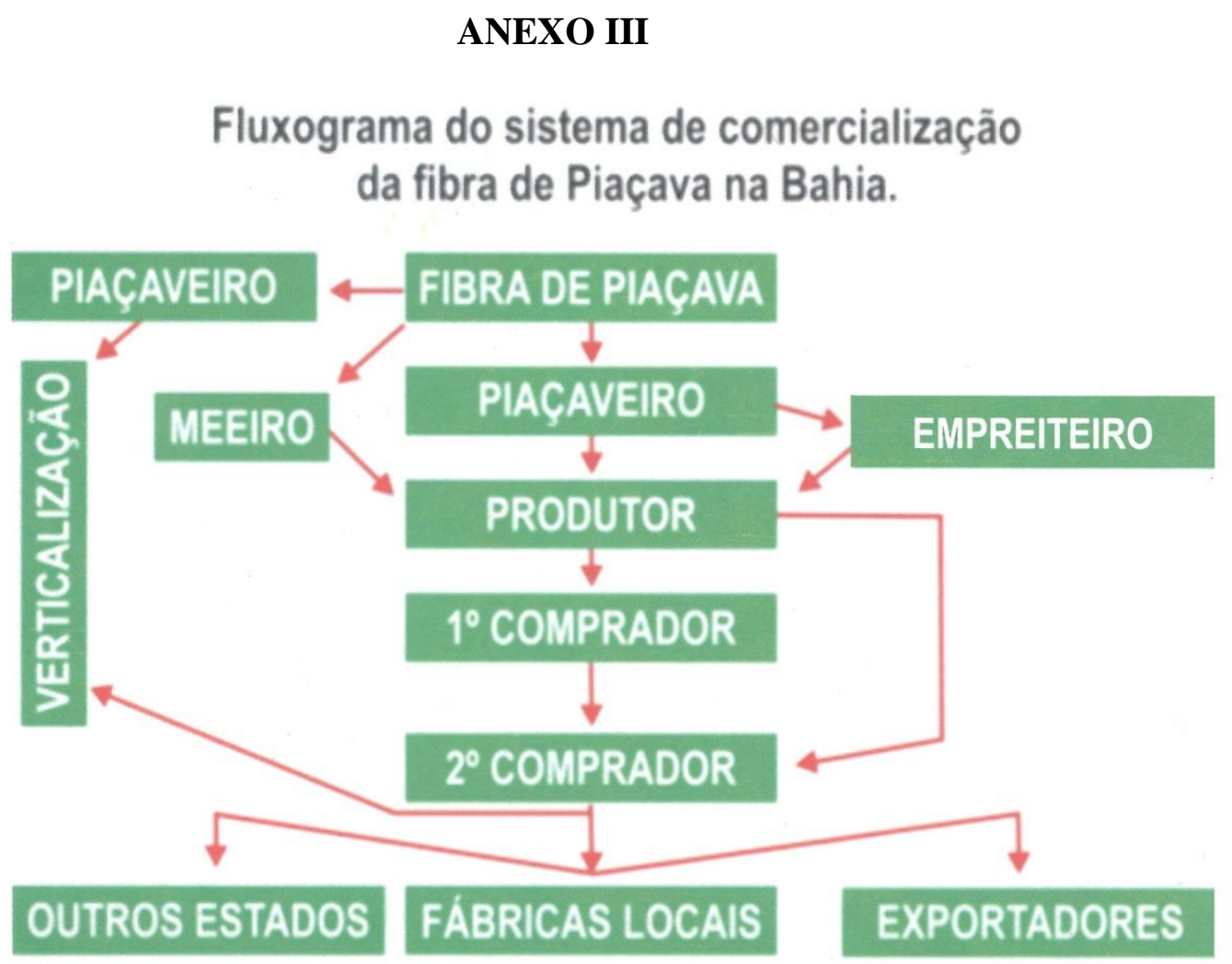

Fonte: Moreau (1997)

Mapa da Cadeia de Valor da Piaçava da Bahia, elaborado pela equipe do DEX/MMA (2009) apud Oliveira (2012). 


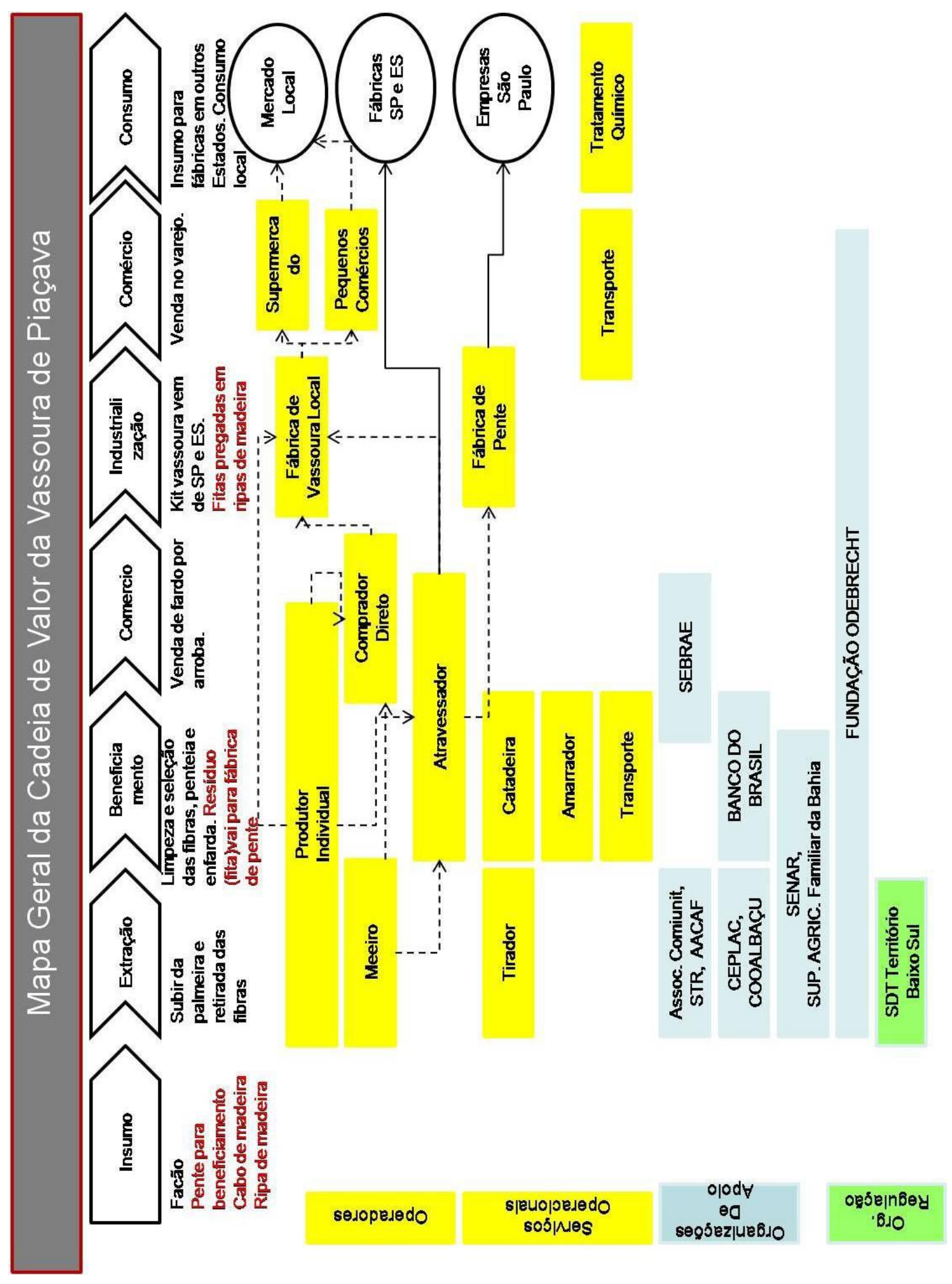




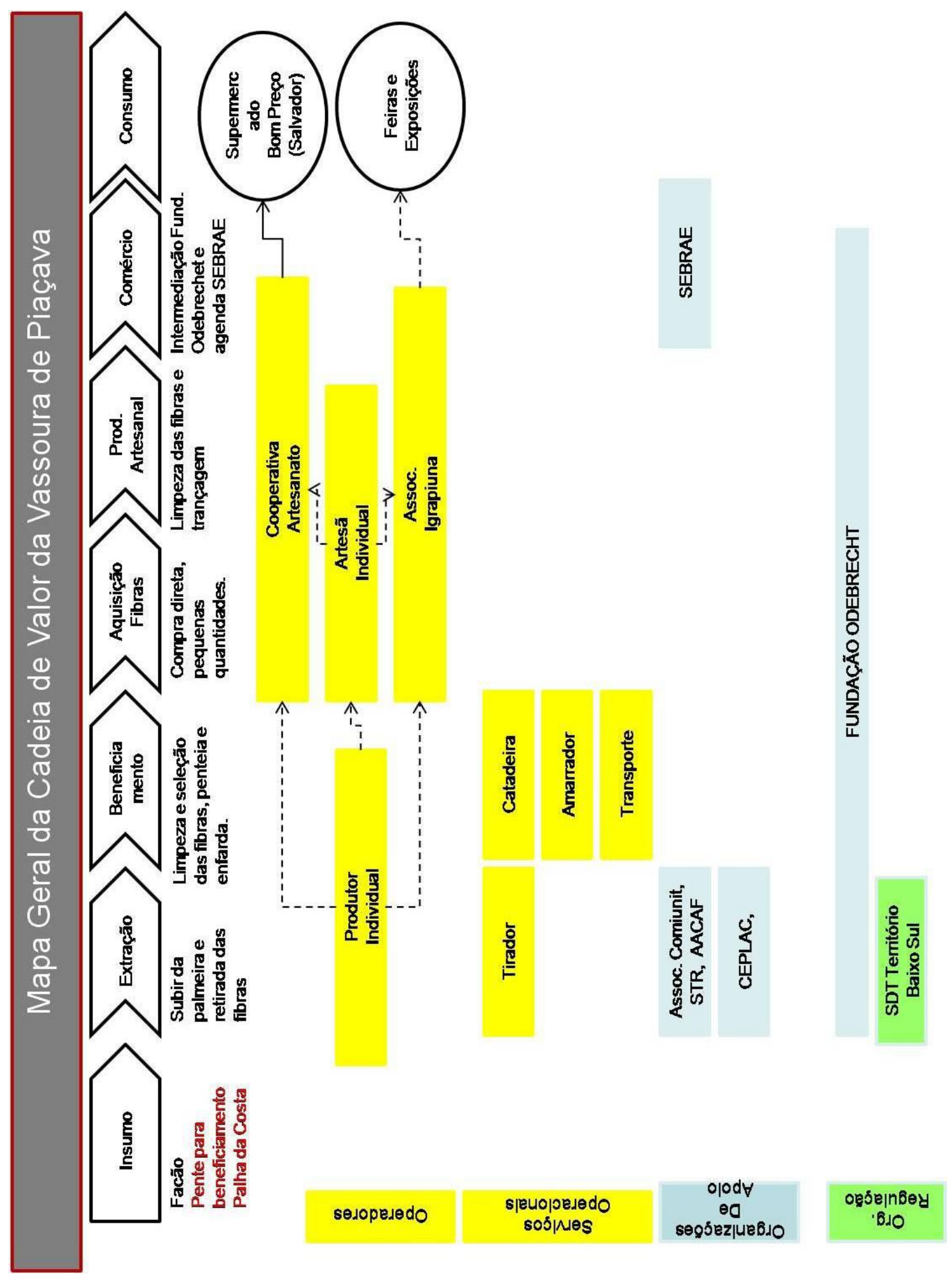




\section{ANEXO IV}

SEBRAE, 2013. Benefícios da piaçava. Revista Conexão Bahia, publicação do SEBRAE Bahia $n^{\circ}$ 204, pgs 15-17. Endereço eletrônico: http://issuu.com/sebraebahia/docs/conexao, acesso em abril 2015.

\section{Benefícios da piaçava}

Óleo e fécula da piaçava ajudam a emagrecer e combater a desnutrição, e podem gerar emprego e renda

Aos 82 anos, o médico pediatra de Salvador Antônio Sturaro é um exemplo de espírito inovador para os jovens empresários da Bahia. Entre os empreendedores que mostraram seus produtos e serviços nas vitrines do Espaço de Inovação, da Feira do Empreendedor, em outubro, o médico foi um dos destaques. Ele apresentou três produtos oniginários de seus estudos e pesquisas com o fruto da piaçava: o granito vegetal, o óleo do coco da piaçava e o satim, uma fécula que serve como complemento alimentar. Estes produtos podem beneficiar cerca de 40 mil produtores de piaça- va da Bahia e mais de 280 mil pessoas. A maioria sobrevive da comercialização da palha da piaçava apenas para a fabricaçāo de vassouras. Estes produtores estão concentrados na região do Baixo Sul da Bahia, nos municípios de Camamu, Taperoá, Valença, Ihéus e Nilo Peçanha, que 
respondem por $94 \%$ da produção brasileira da piaçava

"A minha inspiração para inovar com os produtos originais da piaçava veio do trabalho desenvolvido pela Fundaçāo Odebrecht, no Programa de Desenvolvimento e Crescimento Integrado com Sustentabilidade do Mosaico de Áreas de Proteçằo Ambiental do Baixo Sul da Bahia, onde está a maioria da produçāo da piaçava do Brasil", conta o médico Antônio Sturaro.

"Estes produtores que sobrevivem da piaçava podem ficar sem trabalho, já que o produto economicamente utilizado da piaçava, a fibra para fazer vassouras, está sendo substituida pelas vassouras sintéticas. A exportaçāo da fibra da piaçava está diminuindo", alerta o médico.

\section{Produtos inovadores $e$ seus benefícios}

Granito vegetal - material para revestimento de piso à base do endocarpo do coco da piaçava e que já teve a patente requerida junto ao Instituto Nacional de Propriedade Industrial (INPI). Este granito tem uma alta resistência mecânica, beleza estética. "Além da beleza, este 'granito vegetal', que os egípcios chamam de marfim vegetal, tem resistência, é têrmico. Ao contrário do granito comum, que é frio, este é quente e pode ser usado no lugar da cerâmica", explica o médico.

Óleo láurico - é um complemento alimentar e agente fitoterápico, extraido da amêndoa do coco da piaçava. 0 produto também já teve sua patente requerida junto ao INPI. Além de ge- rar emprego e renda para produtores rurais, o óleo láurico, nos âmbitos nutricional e terapêtutico, funciona como cosmética antioxidante, ajuda no pro cesso de emagrecimento, porque quei. ma a gordura desnecessária, e man-

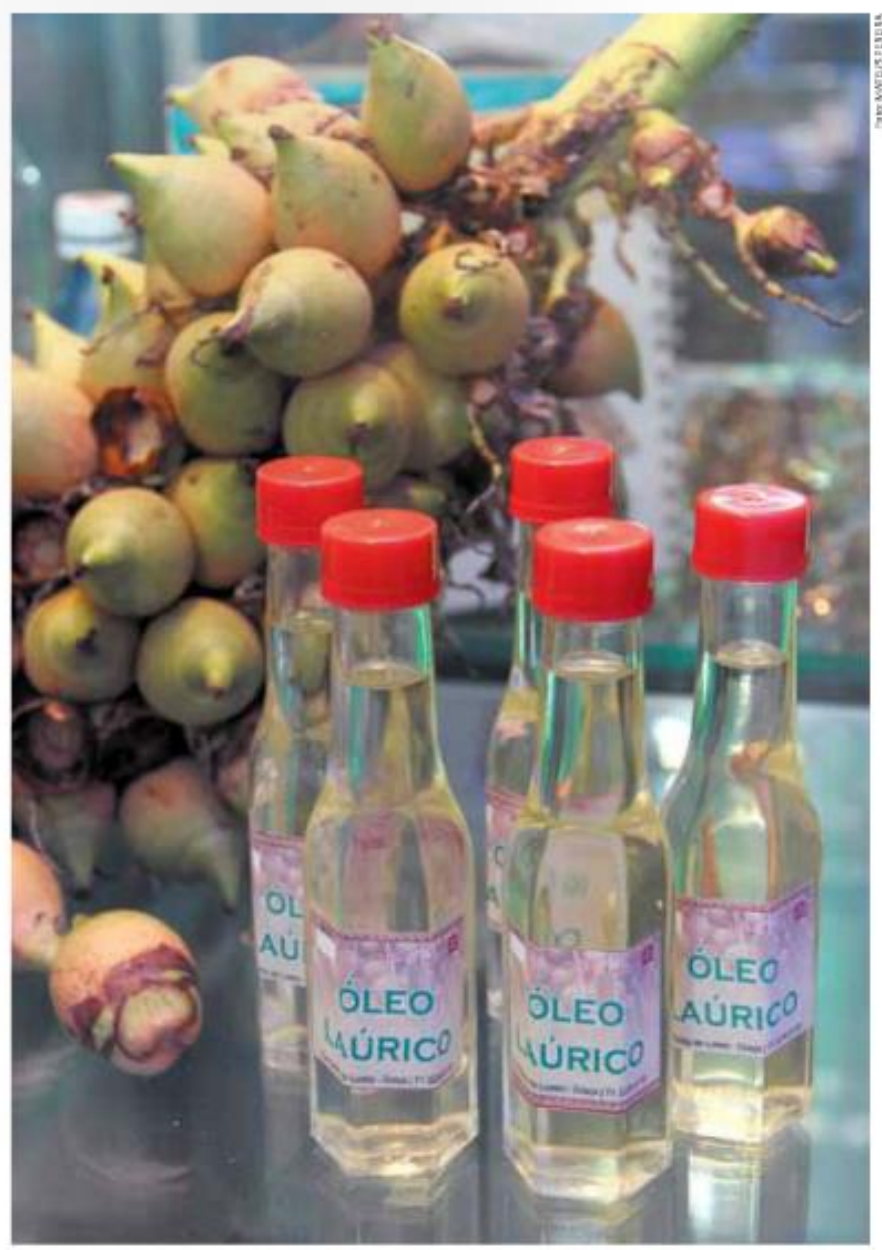

Oieo bäurico é antioxidante, jJuda no processo de emagrecimento, baixa o coiesterol e melhara o sistemo Emisialígico

tém a gordura boa, baixa o colesterol, e melhora o sistema imunológico. Para os diabéticos, impede a compulsāo por carboidrato e, quando usado na pele, ele tem uma açāo antiinflamatória po. derosa, combatendo a fibromialgia.

\section{(}


Satim - Complemento alimentar à base de fécula do coco da piaçava, o Satim ajuda a suprir a falta de alguns nutrientes necessários para o corpo humano (a exemplo do ferro, cálcio, magnésio e potássio). O produto já tem sua patente registrada no INPI, "A fécula pode ser usada em crianças com desnutrição porque é riquíssima em cálcio, em potássio e silício ${ }^{\circ}$, observa o médico Antônio Sturaro.

- consultor do Sebrae Bahia, Sergio Antonio, que acompanha - processo de regularização dos produtos, informou que está assessorando o médico no protocolo de patentes dos produtos junto ao INPI. "Já tivemos acesso ao laudo da Unicamp, mostrando a composição e os benefícios do óleo láurico do coco da piaçava. Também estamos fazendo um plano de negócio para que os produtos recebam consultorias do Sebraetec. A partir do Sebraetec serão apresentadas propostas de laboratónios para avaliar a composiçào do granito e do satim", explica o consultor.

\section{Mais de 15 mil pessoas visitaram o espaço Faça Diferente: inovar é um ótimo negócio}

Inovar não requer apenas grandes investimentos e tecnologia. A criatividade pode trazer soluçōes simples ao alcance dos pequenos negócios. O espaço "Faça diferente: inovar é um grande negócio", da Feira do Empreendedor 2013, recebeu mais de 15 mil visitantes, que conheceram invençōes para melhorar o dia a dia das pessoas, além de constatar açōes de competitividade e divulgação.

\section{Estes produtores que} sobrevivem da piaçava podem ficar sem trabalho, já que o produto economicamente utilizado da piaçava, a fibra para fazer vassouras, está sendo substituída pelas vassouras sintéticas. A exportação da fibra da piaçava está diminuindo

Através de mesas digitais, em uma linguagem simples e dinâmica, foram apresentadas as principais soluçôes de Inovação e Tecnologia nas áreas de Design, Tecnologia da Informação e Comunicação e Tecnologia Indústria Básica. Um dos programas exibidos foi o de Segurança Alimentar, que ensina as boas práticas de fabricação, higiene e manipulação de produtos para que a empresa ofereça alimentos seguros e evite desperdícios, durante sua produção, transporte $\mathrm{e}$ manipulação.

Outro programa exposto foi o Cinco Menos que São Mais, que ajuda o empresánio na identificação de desperdicios de insumos no processo produtivo da sua empresa e propōe açōes corretivas, com o objetivo de diminuir custos de produção, aumentar a produtividade e minimizar os impactos ambientais negativos. O programa disponibi- liza um consultor que, durante 12 meses, mostra ao empresário que o desperdicio gera prejuizo e contabiliza em reais quanto ele está deixando de ganhar.

De acordo com a coordenadora da Unidade de Inovaçāo e Tecnologia do Sebrae Bahia, Márcia Suêde, - número de visitantes no Espaço mais que triplicou, quando comparado ao da Feira de 2011. Isso mostra que a linguagem simples e dinâmica ajudou a atrair os empreendedores que querem inovar. "O nosso objetivo foi mostrar para - empresário que a inovação é possível, nāo é só para grandes empresas e nâo precisa de investimentos altos. As micro e pequenas empresas podem inovar em marketing, na área financeira, na área contábil, na parte organizacional, com novos processos e novos produtos. $0 \mathrm{em}$ presário pode repensar seus processos, seus serviços e produtos", destaca Márcia Suêde.

Durante sua visita ao Espaço de Inovação na Feira do Empreendedor, o secretário de Ciência, Tecnologia e Inovação do Estado da Bahia, Paulo Câmera, disse que uma das grandes facetas da inovação é crescer, e não se estagnar. "É aí que aparece o Sebrae para fazer a melhoria de renda dos empresários. Eu acho que o estado tem que ser mais agressivo, à medida que nós temos uma população que precisa ser estimulada e educada para os novos padrōes empresariais que surgem com a nova economia baiana*, observou, informando, ainda, que a secretaria tem um dos maiores projetos do Brasil de encubaçāo de empresas. 


\section{APÊNDICE A}

\section{ROTEIRO SEMIESTRUTURADO \\ EXTRATIVISMO TRADICIONAL DA FIBRA DE PIAÇAVA - Attalea funifera}

\section{LEVANTAMENTO DE DADOS PRIMÁRIOS SOBRE EXTRATIVISMO DA FIBRA DE \\ PIAÇAVA - Attalea funifera}

Comunidade:

Entrevistado:

Localização da área de extração:

$1^{\circ}$ herdeiro da área:

Relação dos parentes que tem permissão de extração na área:

Tamanho (ha) da área de extração:

Quantidade de glebas:

Membros da família:

\begin{tabular}{|l|l|l|l|l|l|c|}
\hline \multirow{2}{*}{ Nome } & \multicolumn{2}{|c|}{ Sexo } & \multirow{2}{*}{ Idade } & \multirow{2}{*}{ Parentesco } & \multirow{2}{*}{ Extração } & $N^{\circ}$ \\
\cline { 2 - 7 } & $\mathrm{M}$ & $\mathrm{F}$ & & & \\
\hline & & & & & \\
\hline & & & & & \\
\hline & & & & & \\
\hline
\end{tabular}

\section{I - Aspectos Econômicos e Produtivos}

1. Descrição das Atividades Produtivas que Compõem a renda familiar:

2. Quantidade de fibra bruta comprada no mês passado? Quem foram os vendedores? Conhece a localização das áreas de extração? Qual o preço pago?

2.1 Recordam da quantidade de fibra bruta comprada no ano de 2012? Quem foram os fornecedores? Preços praticados?

2.2. Quantidade de fibra limpa vendida no mês passado? Quem foram os compradores? Valor recebido pela fibra limpa? E a subvenção? Onde estão localizados? Quais os produtos produzidos com a fibra?

2.3. Quantidade de pentes produzidos? Mensal e anual? Preços praticados?

2.4. Tamanho dos cortes das fibras limpas comercializadas no catadouro familiar? Como se dá a seleção e classificação da fibra?

2.5. Descrição das etapas de beneficiamento da fibra e pente. Equipamentos utilizados. Tamanho do espaço físico do catadouro.

2.6. Quais as técnicas de beneficiamento que os membros da família dominam? Sabem limpar, catar, selecionar, formar os feixes? Quais os tipos de artesanatos que a família sabe confeccionar? O mingau de 'satin' está inserido na dieta familiar? Conhecem as biojóias? Já fizeram vassouras de piaçava? 
2.7. O bagaço, resíduo da cata das fibras, é utilizado para algum fim? Tem sugestão de uso? Qual o fim dado?

2.8. Os produtos comprados e vendidos são de boa qualidade? Características das fibras de $1^{\circ}$ e $2^{\circ}$. Quais as de mudanças que os clientes gostariam?

3. Apontar as principais dificuldades relacionadas ao beneficiamento e comercialização da fibra limpa de piaçava.

\section{II - Aspectos Sócio Culturais}

1. Quais as festas tradicionais do quilombo? E a festa da sua preferência?

2. Quais as manifestações culturais que os seus antepassados faziam que hoje não são mais praticadas?

3. Quais histórias ou estórias relacionadas a piaçava? Existe algum uso tradicional da espécie que hoje não é mais praticado?

\section{IV - EXTRAÇÃO:}

1. A família faz a extração da fibra no território quilombola
( ) Sim
( ) Não

2. O fornecedor de fibra bruta retira a fibra:

( ) Área própria
( ) Área de Terceiros
( ) Concessão de Uso

3. Informações sobre a Extração da Fibra:

\begin{tabular}{|l|l|l|l|l|l|l|}
\hline Nome do Local & Área & $\begin{array}{c}\text { Deslocamento } \\
\text { (horas) }\end{array}$ & $\begin{array}{c}\text { Número } \\
\text { palmeira }\end{array}$ & $\begin{array}{c}\text { Fibras/ } \\
\text { palmeira }\end{array}$ & $\begin{array}{c}\text { Produção } \\
\text { Passada(k } \\
\text { g) }\end{array}$ & $\begin{array}{c}\text { Produção } \\
\text { Anual(kg) }\end{array}$ \\
\hline & & & & & & \\
\hline
\end{tabular}

4. Quantos indivíduos são encontrados em um hectare?

5. Onde estão os indivíduos mais produtivos? Sabem quantos são?

6. Um indivíduo produz quanto de fibra e fruto?

7. Quanto se deve extrair?

8. Quanto se deve deixar?

9. Qual a idade que o indivíduo começa a produzir ou está pronto para realização da primeira extração?

10. Quais os materiais utilizados na extração?

( ) Facão e/ou Machado

( ) EPI - Botas, luvas, bainha, calça e boné

( ) Outros 
11. Como é feito o transporte do local de extração para a comunidade?

( ) Carrinho de mão

( ) Animal

( ) Veículo

( ) A pé

12. Quanto um extrator/tirador consegue extrair por dia?

13. Existem áreas onde não se pode fazer extração?

14. Existem acordos de extração feitos pela comunidade? Que tipo?

15. Onde são armazenados as fibras?

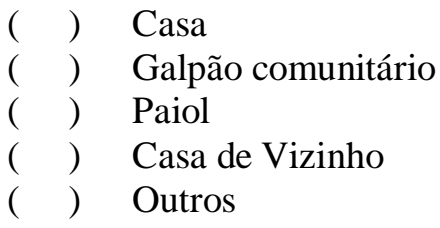

16. Descrição detalhada do momento de coleta até o transporte para unidade de processamento, residência, outros:

17. Existe perda do produto extraído?

( ) Sim
( Não

18. Como é feito o pré-beneficiamento da fibra vegetal na comunidade? E como é feita?

18. Existe equipamento para o pré-beneficiamento?

19. Qual é o tipo de processamento realizado pela família na comunidade?

\section{V - MEIO AMBIENTE}

1. Observaram quais são as plantas vizinhas dessa espécie?

2. Como é o ambiente onde a espécie prefere para crescer e se desenvolver?

3. Número de frutos deixados no momento da coleta?

4. Número árvores produtivas não coletadas?

5. Quais os danos que os indivíduos sofrem durante a extração?

6. Quais as técnicas/formas para evitá-los ou diminuí-los?

7. Existem épocas, luas, ou cuidados durante a extração que atrapalham a qualidade do produto final? Quais são?

8. Fazem uso de queimadas? ( ) Sim ( ) Não

9. Na propriedade ou área de coleta existem cursos d'água ou nascentes?

( ) Sim ( ) Não

10. Possuem vegetação em suas margens? ( ) Sim ～～） Não

11. Existem áreas sendo desmatadas ou abertas? ( ) Sim ～～） Não 
12. Observam a presença de fauna próxima às árvores? ( ) Sim ～～） Não

13. Quais os animais observados? Locais da observação?

14. Existem plântulas crescendo no campo, na área de coleta?

( ) Sim ( ) Não

Produzem mudas? ( ) Sim ( ) Não

Plantam próximo das casas na comunidade? ( ) Sim ( ) Não

17. Tem alguma técnica ou observação que venha contribuir com a conservação da espécie explorada?

18. Como o manejo, o processamento e a comercialização contribuem com a conservação do ecossistema explorado?

19. Opinião dos coletores, extratores, comunidade envolvida sobre as boas práticas de manejo dos PFNMs.

\section{APÊNDICE B}

\section{ROTEIRO SEMIESTRUTURADO: COOPERATIVAS}

Variáveis Econômicas

1.Tipos de produtos produzidos?

\begin{tabular}{|l|c|c|}
\hline Item & Produto & Preço R\$ \\
\hline 1 & & \\
\hline 2 & & \\
\hline
\end{tabular}

2. Produção anual de fibra?

\begin{tabular}{|c|c|c|c|c|c|c|c|}
\hline Ano & 2006 & 2007 & 2008 & 2009 & 2010 & 2011 & 2012 \\
\hline $\mathrm{R} \$$ & & & & & & & \\
\hline $\mathrm{Kg}$ & & & & & & & \\
\hline
\end{tabular}

3. Produção anual de vassouras?

\begin{tabular}{|c|c|c|c|c|c|c|c|}
\hline Ano & 2006 & 2007 & 2008 & 2009 & 2010 & 2011 & 2012 \\
\hline R $\$$ & & & & & & & \\
\hline Quant. & & & & & & & \\
\hline
\end{tabular}

4. Produção anual de artesanatos?

\begin{tabular}{|c|c|c|c|c|c|c|c|}
\hline Ano & 2006 & 2007 & 2008 & 2009 & 2010 & 2011 & 2012 \\
\hline R $\$$ & & & & & & & \\
\hline Quant. & & & & & & & \\
\hline
\end{tabular}

5. Produção anual de biojóias?

\begin{tabular}{|c|c|c|}
\hline Ano & 2012 & 2013 \\
\hline R $\$$ & & \\
\hline Quant. & & \\
\hline
\end{tabular}

6. Produção por Polo?

\begin{tabular}{|c|c|c|c|}
\hline Polo & Jatimane & São Francisco & Lagoa Santa \\
\hline Produção/Quant. & & & \\
\hline
\end{tabular}




\begin{tabular}{|l|l|l|l|}
\hline $\mathrm{N}^{\circ}$ artesãs & & \\
\hline
\end{tabular}

7. Custo de Produção e Margem de Lucro?

\begin{tabular}{|c|c|c|}
\hline Produto & Custo & Margem \\
\hline Vassoura de cepo & & \\
\hline
\end{tabular}

8. Como é calculado o custo de produção?

Vassouras:

Cepo $=$

Pia $=$

Redonda $=$

Chapa $=$

Limpeza urbana $=$

Artesanatos:

Cestos grandes=

Cestos pequenos $=$

Chaveiros $=$

Porta caneta $=$

Biojóias:

Brinco=

Anel $=$

Bracelete $=$

Colares $=$

9. Comercialização de fibras limpas e cortadas; vassouras; artesanatos; biojóias. Quem são os compradores?

\begin{tabular}{|l|l|l|l|}
\hline Empresa & Produtos & Quantidade & Ano \\
\hline & & & \\
\hline & & & \\
\hline & & & \\
\hline & & & \\
\hline
\end{tabular}

10. Fornecedores de insumos?

\begin{tabular}{|l|l|l|}
\hline Produto & Empresa & Valor unitário R\$ \\
\hline & & \\
\hline & & \\
\hline & & \\
\hline & & \\
\hline
\end{tabular}

Processamento

1. Equipamentos necessários para o pré beneficiamento da fibra? Descrição da transformação da fibra bruta em fibra limpa e cortada?

2. Equipamentos necessários para o beneficiamento da fibra em vassouras? Descrição das técnicas de transformação da fibra limpa e cortada em vassouras?

3. Qual o rendimento do processo produtivo? Quantos por cento das fibras limpas e cortadas são transformadas em vassouras?

4. Quanto é resíduo? matéria prima não aproveitada?

5. Qual a produtividade diária (8 horas trabalhada de cada funcionário)? 
6. Como é feita a gestão da produção na sede da cooperativa? E a gestão dos cooperados produtores?

7. E o controle de qualidade na produção de vassouras e pré beneficiamento realizados nos 'catadouros'?

10. Definição e destino das fibras A e B?

11. Armazenamento?
a. Fibras Bruta
b. Fibra Limpa
c. Fibra Cortada
d. Fruto/Coco
e. Vassouras
f. Artesanatos
g. Biojóias

12. Como é realizado o transporte das fibras brutas? fibras cortadas? vassouras? Dificuldade dos cooperados e produtores com relação ao transporte?

Sócio - Ambiental

1. Quantidade de trabalhadores na sede da cooperativa?

2. Quantidade de cooperados?

3. Número de famílias envolvidas com o fornecimento de fibras limpas e cortadas?

4. Quantos são quilombolas?

5. Quantos são agricultores familiares?

6. Renda média das famílias envolvidas com a cooperativa?

7. Número de cooperados e/ou famílias envolvidas com a produção de piaçava, ao longo dos anos?

\begin{tabular}{|c|c|c|c|c|c|c|c|}
\hline Ano & 2006 & 2007 & 2008 & 2009 & 2010 & 2011 & 2012 \\
\hline $\mathrm{N}^{\circ}$ cooperados & & & & & & & \\
\hline Renda/cooperado & & & & & & & \\
\hline
\end{tabular}

8. Localização das áreas de extração das fibras? Assentamento? Qual? Município?Área?

Quilombo?

9. Práticas de Extração? Fazem incisão nos troncos? Utilizam escadas para subida? Extratores utilizam EPI? Quantas talas (folhas) são retiradas a cada extração?

10. Existe monitoramento das áreas de extração? Como ele é realizado?

\section{APÊNDICE C}

\section{APÊNDICE C - FORMULÁRIOS PARA ENSAIOS DE RENDIMENTO PRE-BENEFICIAMENTO}

Sistema Produtivo:

Localização da Unidade Produtiva:

Data:

Produto: Fibra Limpa e Fita

\begin{tabular}{|c|c|c|c|c|c|c|c|}
\hline Repetições & $\begin{array}{c}\text { Peso } \\
(\mathrm{kg}) \text { Inicial }\end{array}$ & \multicolumn{2}{|c|}{$\begin{array}{c}\text { Tempo Separação e } \\
\text { Limpeza } \\
(\mathrm{min})\end{array}$} & \multirow{2}{*}{$\begin{array}{c}\text { Fibra } \\
(\mathrm{kg})\end{array}$} & $\begin{array}{c}\text { Fita } \\
(\mathrm{kg})\end{array}$ & $\begin{array}{c}\text { Res. I } \\
(\mathrm{kg})\end{array}$ & Observações \\
\cline { 3 - 5 } & & $\mathrm{I}$ & $\mathrm{F}$ & & & & \\
\hline 1 & & & & & & & \\
\hline 3 & & & & & & & \\
\hline
\end{tabular}




\section{FORMULÁRIOS PARA ENSAIOS DE RENDIMENTO - BENEFICIAMENTO}

Sistema Produtivo:

Localização da Unidade Produtiva:

Data:

Produtos: Fibra Vegetal Cortada - produto tipo exportação

\begin{tabular}{|c|c|c|c|c|c|c|}
\hline \multirow[t]{2}{*}{ Repetições } & \multirow[t]{2}{*}{$\begin{array}{c}\text { Peso } \\
(\mathrm{kg}) \text { Inicial }\end{array}$} & \multicolumn{2}{|c|}{$\begin{array}{l}\text { Tempo Limpeza, } \\
\text { seleção e corte } \\
\text { (min) }\end{array}$} & \multirow[t]{2}{*}{$\begin{array}{c}\text { Fibra } \\
(\mathrm{kg})\end{array}$} & \multirow[t]{2}{*}{$\begin{array}{c}\text { Res. I } \\
\text { (kg) }\end{array}$} & \multirow[t]{2}{*}{ Observações } \\
\hline & & I & $F$ & & & \\
\hline 1 & & & & & & \\
\hline 2 & & & & & & \\
\hline 3 & & & & & & \\
\hline 4 & & & & & & \\
\hline 5 & & & & & & \\
\hline 6 & & & & & & \\
\hline
\end{tabular}

FORMULÁRIOS PARA ENSAIOS DE RENDIMENTO - VASSOURAS DE PIAÇAVA

Localização

da

Unidade

Produtiva:

Data:

Tipos de Vassouras: ( ) Limpeza urbana - 60cm ou 40cm; ( ) cepo - 37cm; ( ) chapa 24cm; ( ) redonda 24cm; ( ) pia $13 \mathrm{~cm}$.

\begin{tabular}{|c|c|c|c|c|c|c|c|c|c|c|}
\hline \multirow[t]{2}{*}{ Rept. } & \multirow[t]{2}{*}{$\begin{array}{c}\text { Peso } \\
\text { (kg) Inicial }\end{array}$} & \multicolumn{2}{|c|}{$\begin{array}{l}\text { Tempo Confecção } \\
\text { (min) }\end{array}$} & \multirow{2}{*}{$\begin{array}{c}\text { Fibra } \\
\text { Fina } \\
(\text { kg) }\end{array}$} & \multirow{2}{*}{$\begin{array}{c}\text { Fibra } \\
\text { Grossa } \\
\text { (kg) }\end{array}$} & \multirow[t]{2}{*}{$\begin{array}{c}\text { Res. I } \\
(\mathbf{k g})\end{array}$} & \multirow{2}{*}{$\begin{array}{c}\mathbf{N}^{\circ} \\
\text { Vassour } \\
\text { as }\end{array}$} & \multirow[t]{2}{*}{$\begin{array}{c}\mathrm{N}^{\circ} \text { furos } \\
\text { incomplet. }\end{array}$} & \multirow{2}{*}{$\begin{array}{c}\text { Fibra } \\
\text { Grossa } \\
\text { (kg) }\end{array}$} & \multirow[t]{2}{*}{$\begin{array}{c}\text { Res.II } \\
\text { (kg) }\end{array}$} \\
\hline & & I & $\mathbf{F}$ & & & & & & & \\
\hline 1 & 2 & & & & & & & & & \\
\hline 2 & 2 & & & & & & & & & \\
\hline 3 & 2 & & & & & & & & & \\
\hline 4 & 2 & & & & & & & & & \\
\hline 5 & 2 & & & & & & & & & \\
\hline 6 & 2 & & & & & & & & & \\
\hline 7 & 2 & & & & & & & & & \\
\hline 8 & 2 & & & & & & & & & \\
\hline 9 & 2 & & & & & & & & & \\
\hline 10 & 2 & & & & & & & & & \\
\hline 11 & 2 & & & & & & & & & \\
\hline 12 & 2 & & & & & & & & & \\
\hline 13 & 2 & & & & & & & & & \\
\hline 14 & 2 & & & & & & & & & \\
\hline
\end{tabular}

